
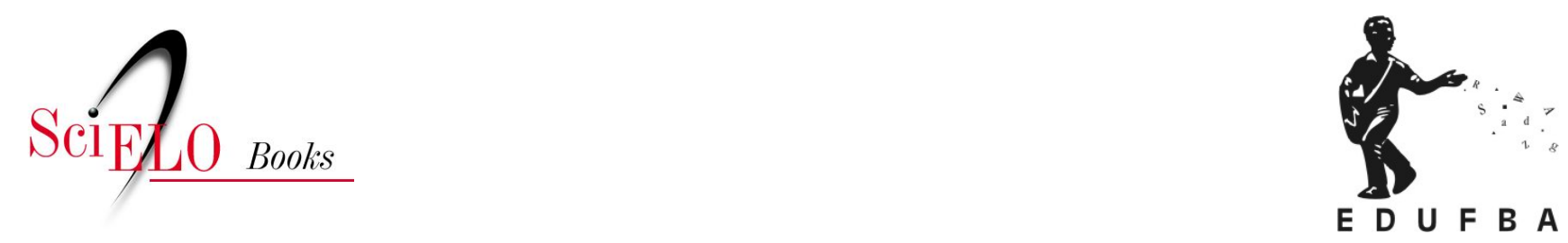

\title{
Ditadura militar na Bahia
}

novos olhares, novos objetos, novos horizontes - Vol. 1

Grimaldo Carneiro Zachariadhes

(org.)

\section{SciELO Books / SciELO Livros / SciELO Libros}

ZACHARIADHES, GC., org. IVO, AS., et al. Ditadura militar na Bahia: novos olhares, novos objetivos, novos horizontes [online]. Salvador: EDUFBA, 2009, vol. 1, 285 p. ISBN 978-85-2321182-0. Available from SciELO Books $<$ http://books.scielo.org $>$.

\section{(2)(1)(2)}

All the contents of this chapter, except where otherwise noted, is licensed under a Creative Commons Attribution-Non Commercial-ShareAlike 3.0 Unported.

Todo o conteúdo deste capítulo, exceto quando houver ressalva, é publicado sob a licença Creative Commons Atribuição - Uso Não Comercial - Partilha nos Mesmos Termos 3.0 Não adaptada.

Todo el contenido de este capítulo, excepto donde se indique lo contrario, está bajo licencia de la licencia Creative Commons Reconocimento-NoComercial-CompartirIgual 3.0 Unported. 


\section{DITADURA MILITAR NA BAHIA}

Novos Olhares, Novos Objetos, Novos Horizontes 


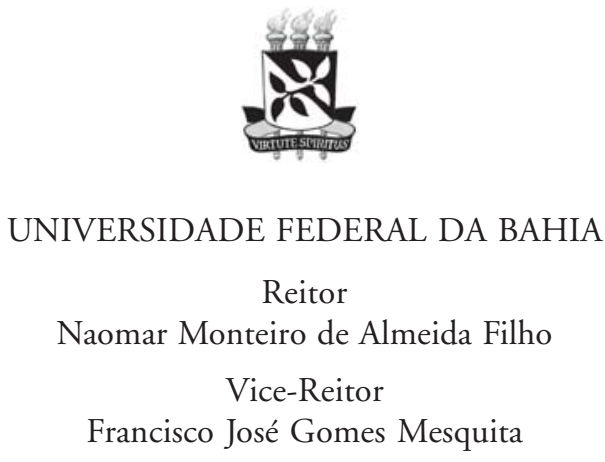

EDITORA DA UNIVERSIDADE FEDERAL DA BAHIA

Diretora

Flávia Goullart Mota Garcia Rosa

Conselho Editorial

Titulares

Ângelo Szaniecki Perret Serpa

Caiuby Alves da Costa

Charbel Ninô El-Hani

Dante Eustachio Lucchesi Ramacciotti

José Teixeira Cavalcante Filho

Maria do Carmo Soares Freitas

\author{
Suplentes \\ Alberto Brum Novaes \\ Antônio Fernando Guerreiro de Freitas \\ Armindo Jorge de Carvalho Bião \\ Evelina de Carvalho Sá Hoisel \\ Cleise Furtado Mendes \\ Maria Vidal de Negreiros Camargo
}




\section{GRIMALDO CARNEIRO ZACHARIADHES}

(Organizador)

Alex de Souza Ivo - Antonio Mauricio Freitas Brito - Cristiane Soares de Santana Ediane Lopes de Santana - Elizete da Silva - Izabel de Fátima Cruz Melo - José Alves Dias - Joviniano Soares de Carvalho Neto - Margarete Pereira da Silva - Maria Victoria Espiñeira - Sandra Regina Barbosa da Silva Souza - Sílvio César Oliveira Benevides

\section{DITADURA MILITAR NA BAHIA}

Novos Olhares, Novos Objetos, Novos Horizontes

VOLUME I

Salvador

EDUFBA 
(C)2009 by Organizadores

Direitos de edição cedidos à

Editora da Universidade Federal da Bahia - EDUFBA

Feito o depósito legal

\author{
Normalização \\ Normaci Correia dos Santos \\ Revisão de linguagem \\ Magel Castilho de Carvalho \\ Editoração eletrônica e capa \\ Rodrigo Oyarzábal Schlabitz
}

Sistema de Bibliotecas - UFBA

Ditadura militar na Bahia : novos olhares, novos objetos, novos horizontes / Grimaldo

Carneiro Zachariadhes (organizador) ; Alex de Souza Ivo... et al. - Salvador : EDUFBA, 2009.

v. 1

ISBN 978-85-232-0640-6

1. Bahia - História - 1964-1985. 2. Bahia - Política e governo - 1965-1985. I.

Zachariadhes, Grimaldo Carneiro. II. Ivo, Alex de Souza.

CDD - 98142

\title{
Asociación de Editoriales Universitarias
de América Latina yel Caribe
}
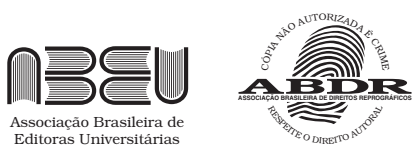

EDUFBA

Rua Barão de Jeremoabo, s/n - Campus de Ondina,

40170-115 Salvador-BA

Tel/fax: (71) 3283-6164

www.edufba.ufba.br

edufba@ufba.br 


\section{AGRADECIMENTOS}

Aos professores, alunos e funcionários da Escola Municipal Anna Amélia Queiroz Carneiro de Mendonça, particularmente, às professoras Edna Moreira Dias e Sônia Pedrina Ferreira Duarte Silva.

Aos moradores do Casarão da Lapa, no Rio de Janeiro, Jamil dos Reis, Lili Santana, Antonio Barboza, Samuel Luna, Filipe de Matos, Marcos e Raimundo.

Às minhas queridas amigas Adriana Martins dos Santos, Lígia Conceição Santana, Creonice Bonfim dos Santos e Elisângela Lopes.

À minha família: meu pai Grimaldo, meus irmãos Ronaldo e Raquel, e a minha mãe, a guerreira Maria Conceição.

À minha companheira e confidente Andréia Santos Silva.

A todos os autores que participaram desta obra e ajudaram a preencher uma lacuna na historiografia baiana. 



\section{SUMÁRIO}

\section{APRESENTAÇÃO 9}

1 Campanha de desestabilização de Jango: as 'donas' saem às ruas! Ediane Lopes de Santana 13

2 Protestantes e o governo militar: convergências e divergências Elizete da Silva 31

3 Uma "revolução" contra o comuno-peleguismo: o golpe de 1964 e o sindicalismo petroleiro Alex de Souza Ivo $\quad 53$

$4 \mathrm{O}$ golpe de 1964 e as dimensões da repressão em Vitória da Conquista José Alves Dias 69

5 Salvador em 1968: um breve repertório de lutas estudantis universitárias Antonio Mauricio Freitas Brito 89

6 Aventuras estudantis em tempos de opressão e fuzis Silvio César Oliveira Benevides 115

7 Bandeira Vermelha: aspectos da resistência armada na Bahia Sandra Regina Barbosa da Silva Souza 127

8 Notas sobre a história da Ação Popular na Bahia (1962-1973) 


\section{Dom Avelar Brandão Vilela e a ditadura militar}

Grimaldo Carneiro Zachariadhes $\quad 175$

10 No meio do caminho tinha uma Jornada, ou era ela o caminho? Jornadas de Cinema da Bahia (1972-1978)

Izabel de Fátima Cruz Melo 191

11 A resposta da Bahia à repressão militar: a ação partidária da Ala Jovem do MDB e a militância civil do trabalho conjunto da cidade de Salvador Maria Victoria Espiñeira 215

\section{$12 \mathrm{O}$ bispo de Juazeiro e a ditadura militar}

Margarete Pereira da Silva 241

13 O II Congresso da Anistia: momento de resistência e definiçōes Joviniano Soares de Carvalho Neto 259 


\section{APRESENTAÇÃO}

Tenho dito aos que costumam dizer que sobre a ditadura já se escreveu muito, que ainda resta um longo caminho a percorrer para que compreendamos o que foram os 21 anos de domínio militar sobre o país. Foi um tempo de terror desenvolvido e praticado pela ditadura. Este livro, organizado por Grimaldo Carneiro Zachariadhes, dá mais um passo nessa caminhada. Uma parte da história daquele tempo é elucidada, especificamente a que diz respeito à Bahia. Uma contribuição importante, e que abre portas para outras iniciativas, quem sabe para desenvolver vários temas presentes neste trabalho.

Não se sabe se propositadamente ou não, mas há, no livro, uma presença significativa de temas relativos às igrejas, de modo especial da católica, tanto de seus aspectos institucionais mais amplos, quanto girando em torno de personalidades.

Há um mergulho de Elizete da Silva em torno da atuação dos protestantes, batistas e presbiterianos, com destaque, no texto, para os primeiros. $\mathrm{O}$ trabalho mostra a adesão dos religiosos batistas à ditadura, a repressão a professores progressistas nos seminários presbiterianos, embora revele também a existência de vozes corajosas, esparsas, que se colocavam ao lado dos que combatiam a ditadura, como os reverendos Áureo Bispo dos Santos, João Dias de Araújo e Celso Dourado, todos presbiterianos, e Agostinho Muniz, da Juventude Batista.

Embora de passagem, a Igreja Católica volta a ocupar a cena quando da análise sobre a organização revolucionária Ação Popular, que surge como desdobramento da militância e, talvez possamos dizer dessa maneira, da conversão de parte da Juventude Universitária Católica (JUC) à causa da revolução. Diria que o título é acertadamente cuidadoso quando fala em "notas" sobre a história da AP, pois, de fato, ainda estamos muito distantes de uma pesquisa mais abrangente sobre essa organização, que teve papel fundamental na vida política do país, especialmente entre o seu nascimento e o ano de 1973, que é o período abrangido pelo trabalho de Cristiane Soares de Santana. 
O cardeal D. Avelar Brandão Vilela é, de alguma forma, resgatado por Grimaldo Carneiro Zachariadhes. O religioso, verdadeiramente um moderado, foi, a seu modo, um aliado dos que lutavam contra a ditadura e granjeou, por isso, uma antipatia muito grande entre os militares. Não se esperasse dele qualquer atitude panfletária, nem qualquer manifestação muito explícita contra a ditadura.

Mas podia ter atitudes surpreendentes, como a de celebrar uma missa no início dos anos 70, creio que 1972 ou 1973, na Penitenciária Lemos Brito, para os presos políticos e seus familiares, incentivando manifestações libertárias no decorrer do Ofertório. Disso fui testemunha direta. Preso, participei da missa. D. Avelar, a depender das circunstâncias, poderia ser muito duro com os militares, como foi, ao não permitir, com uma intervenção enérgica, que o jesuíta Cláudio Perani fosse mandado de volta para sua terra natal, a Itália.

A atuação do bispo de Juazeiro, D. José Rodrigues de Souza, merece uma análise cuidadosa de Margarete Pereira da Silva. Foi ele que conduziu a Igreja a uma reviravolta em torno da Barragem de Sobradinho, que cobriria uma área de 4.250 quilômetros quadrados, acumularia 34 bilhões de metros cúbicos de água e deslocaria mais de 70 mil pessoas que habitavam os municípios de Sento Sé, Pilão Arcado, Remanso e Casa Nova, todos eles alcançados pelas águas da barragem. D. José foi ameaçado de morte, enfrentou uma campanha difamatória por parte da elite local, que o acusava de subversão e de ser contra um projeto de desenvolvimento. D. José não se atemorizou e permaneceu sempre ao lado dos ribeirinhos.

O II Congresso da Anistia, realizado entre 15 e 18 de novembro de 1979, em Salvador, é analisado por um de seus principais protagonistas, Joviniano de Carvalho Neto, então presidente do Comitê Brasileiro de Anistia, seção da Bahia. Se considerarmos a condição de militante católico de Joviniano, diríamos que aqui, novamente, a Igreja tem papel destacado. $\mathrm{O}$ texto revela as entranhas do Congresso, as diferenças entre o PC do B e PCB, a luta pela anistia ampla, geral e irrestrita, que deveria prosseguir depois da anistia parcial de agosto daquele ano, o clima da abertura do encontro, os aplausos a Luís Carlos Prestes, principal figura política presente à reunião. Trata-se de importante documento histórico.

Numa outra vertente, e ainda envolvendo crenças e rezas e rosários, Ediane Lopes de Santana aborda a movimentação das mulheres em favor do golpe de 1964 em Salvador, que impressiona pelo contingente feminino que se envolveu. E que revela o quanto a Igreja Católica estava, então, a favor da ditadura. A Marcha da Família, do dia 15 de abril de 1964, em Salvador, teria contado 
com a participação impressionante de 400 mil pessoas. O mulherio católico não poupou esforços no apoio ao golpe militar.

Alex de Souza Ivo analisa o desenvolvimento do sindicalismo petroleiro e a repressão que se abateu sobre ele, com destaque para a atuação de Mário Lima, a maior liderança sindical do período e que morreu recentemente. José Alves Dias, no seu texto intitulado $O$ golpe de 1964 e as dimensóes da repressão em Vitória da Conquista, trata da repressão que se abateu sobre os políticos e militantes de Vitória da Conquista, dedicando especial atenção à principal liderança de esquerda de então, o prefeito Pedral Sampaio, que é preso junto com várias outras lideranças.

Salvador em 1968: um breve repertório de lutas estudantis universitárias, de Antonio Maurício Freitas Brito, é uma tentativa de recuperar o ano mágico na Bahia. É como se fotografasse cronologicamente os acontecimentos. Um importante registro. Faltando uma análise mais contextualizada, que juntasse 1968 com seus antecedentes, inclusive a participação decisiva do movimento estudantil secundarista, que na Bahia teve papel absolutamente decisivo em todas as mobilizações.

Essa lacuna é, de alguma forma, preenchida com o texto seguinte - Aventuras estudantis em tempos de opressão e fuzis, de Sílvio César Oliveira Benevides, que analisa de modo especial a movimentação secundarista de 1966, decorrente da peça "Aventuras e desventuras de um estudante", que fora censurada. Escrita por Carlos Sarno, estudante do Colégio Central, a peça foi o estopim de uma mobilização secundarista que sacudiu Salvador.

Sandra Regina Barbosa, com o texto Bandeira Vermelha: aspectos da resistência armada na Bahia, analisa aspectos da atuação e formação das organizações revolucionárias que seguiram o caminho da luta armada na Bahia, especialmente a Vanguarda Armada Revolucionária Palmares (VAR - Palmares), o Partido Comunista Brasileiro Revolucionário (PCBR) e o Movimento Revolucionário Oito de Outubro (MR-8), e isso entre os anos de 1969 e 1971. O texto revela um esforço significativo de pesquisa. E se constituirá, seguramente, em referência para pesquisadores. Uma leitura atenciosa, no entanto, leva a cobrar, na sequência, uma melhor sistematização, inclusive com a especificação do papel de cada uma das organizaçóes a que ela se refere.

No meio do caminho, aparece a cultura como parte da luta política. São as Jornadas de Cinema da Bahia, presentes até hoje sob a incansável direção de Guido Araújo. É o trabalho de Izabel de Fátima Cruz Melo. Sete jornadas são analisadas, entre 1972 e 1978. A leitura revela e ensina. Revela o quanto havia de militância nos que organizavam as Jornadas. Quase heroísmo. E insisto no 
papel de Guido Araújo. Era essencial que houvesse dedicação e coragem, devido, especialmente, à carência de recursos e a vigilância da repressão política. Ensina muito, ao evidenciar que política e cultura estão sempre entrelaçadas. A cultura era sempre uma pedra no sapato da ditadura.

A professora Maria Victoria Espiñeira, ligeiramente à margem da tônica do livro, envereda pela análise da experiência da Ala Jovem do Movimento Democrático Brasileiro (MDB), pouco conhecida. A Ala Jovem foi principalmente uma iniciativa do Partido Comunista Brasileiro (PCB), entre 1975 e 1979, mas contou, também, no decorrer de sua existência, com a participação de militantes de outras organizações revolucionárias à esquerda do Partidão. Foi a forma política encontrada pela esquerda de opor-se ao adesismo predominante no MDB de então, capitaneado pelo, à época, deputado Ney Ferreira. Participei da Ala Jovem, concorri à presidência enfrentando Sérgio Santana, que venceu.

Os diversos temas abrem portas para novas e necessárias pesquisas, como disse no início desta apresentação. Os diversos trabalhos do livro têm o mérito de chamar outros autores para o combate necessário para se buscar o muito que ainda resta submerso sobre a ditadura na Bahia. Os que construíram esse livro escavaram, escavaram, e encontraram muito da trágica herança sobre esse período de terror e de sombras. Eles nos animam a prosseguir na caminhada.

Emiliano José*

\footnotetext{
* Jornalista, escritor, autor de Lamarca, o capitão da guerrilha; Marighella, o inimigo número um da ditadura militar; As asas invisiveis do padre Renzo e Galeria F-lembranças do mar cinzento, partes I, II e III, entre outros.
} 


\section{1 \\ Campanha de desestabilização de Jango: as 'donas' saem às ruas!}

Ediane Lopes de Santana ${ }^{1}$

O ano era 1961, exatamente no dia 25 de agosto, uma sexta-feira, e a notícia se espalhou como rastilho de pólvora, desmentindo o anúncio feito no dia anterior pelo então governador do Estado da Guanabara, Carlos Lacerda. Este, dizendo-se portador de grave denúncia, transmitiu seu alerta à nação, no dia 24 de agosto, "para um possível golpe de Estado, a ser desferido contra as instituiçõos, pelo Presidente da República e para o qual havia sido convidado pelo Ministro da Justiça, Pedroso Horta" (SILVA, 1975, p. 37). Naquela sexta-feira de agosto, outra notícia era anunciada, o presidente Jânio Quadros, eleito democraticamente a menos de sete meses, apresentava ao país a sua carta-renúncia, seu pedido de demissão:

Fui vencido pela reação e assim deixo o governo.

Nestes sete meses cumpri o meu dever. Tenho-o cumprido dia e noite, trabalhando infatigavelmente, sem prevenções nem rancores [...] Desejei um Brasil para os bra-

${ }^{1}$ Mestra em História Social do Brasil pela Universidade Federal da Bahia. Esta pesquisa contou com o apoio da Fundação de Amparo à Pesquisa do Estado da Bahia (FAPESB). 
sileiros, afrontando, nesse sonho, a corrupção, a mentira e a covardia que subordinam os interesses gerais aos apetites e às ambiçôes de grupos ou indivíduos, inclusive do exterior. Sinto-me, porém, esmagado. Forças terríveis levantam-se contra mim e me intrigam ou infamam, até com a desculpa da colaboração. ${ }^{2}$

Jânio da Silva Quadros foi eleito, em 1961, na chamada dobradinha Jan-Jan, que reunia a União Democrática Nacional (UDN) de Jânio Quadros e o partido de oposição, o Partido Trabalhista do Brasil (PTB) do vice João Belchior Marques Goulart. Em seu governo, Jânio Quadros optou por dar prosseguimento à política de seu antecessor, Juscelino Kubitschek, que abriu o país ao capital estrangeiro, ampliando o endividamento externo brasileiro. Isso refletiu, mais tarde, no governo de João Goulart sob forma de tensões sociais, políticas e econômicas.

Do ponto de vista da política exterior, fortalecida durante o seu governo, Jânio adotou a perspectiva que ficou conhecida como "Política externa independente"3 (MOTTA, 2002, p. 233) - a esta, João Goulart deu prosseguimento quando o sucedeu na presidência da República. Ao tempo em que apresentava seu viés modernizante, Jânio seduzia parte dos grupos mais conservadores da sociedade brasileira com sua proposta de moralização, utilizando-se da vassoura como um dos seus símbolos de campanha.

Ainda hoje a historiografia do período tem se debruçado a respeito do que teria levado Jânio a renunciar. Em uma dessas versōes, Jânio teria blefado ao solicitar sua renúncia, pois o que ele pretendia era o seu retorno, aclamado pelo povo. Nessa versão, Jânio acreditava que seria implorado a voltar, primeiro por causa do vazio político causado pela renúncia, numa República que vinha se recuperando de sucessivas crises; segundo, sabendo das representações negativas que se faziam acerca do seu vice, João Goulart, e pelo agravante deste ser filiado ao partido de oposição, o PTB, Jânio tinha a convicção de que este seria preterido diante da vacância do cargo. O Instituto Brasileiro de Ação Democrática (IBAD) $)^{4}$ não se furtou em utilizar essa versão no seu periódico, a Revista Ação Democrática, quatro meses depois do episódio:

\footnotetext{
${ }^{2}$ Trecho da Carta-renúncia de Jânio Quadros, Brasília, 25 de agosto de 1961.

${ }^{3}$ A política externa independente tendia a aproximar o país das nações não-alinhadas com as posições dos EUA. Para se ter uma dimensão das ações janistas, dentro desta política externa independente, basta lembrar que ele condecorou Che Guevara com a Ordem do Cruzeiro do Sul. Motta (2002). Essa orientação de Jânio foi uma desagradável surpresa para os que votaram nele esperando derrotar a esquerda e o getulismo, o que gerou reações indignadas.

${ }^{4}$ O Instituto Brasileiro de Ação Democrática (IBAD) surge em 1959 visando potenciar ações de combate ao comunismo no Brasil. Mais tarde, no início da década de 60, surge o Instituto de Pesquisa e Estudos Sociais (IPES), que também promoveram ações de combate ao comunismo através de instrumentos ideológicos, como: panfletos, brochuras, livretos, filmes etc...
} 
Hoje sabe-se que o Sr. Jânio Quadros não foi deposto nem forçado a renunciar. Afastou-se livre e espontaneamente, levado pelos impulsos do seu temperamento ou sob a pressão de acusações de ditatorialismo às quais não pôde dar resposta cabal. Talvez supusesse mesmo que o clamor popular e os responsáveis pela política brasileira o fossem buscar de volta e lhe concedessem os plenos poderes sem os quais não se julgava capacitado a governar [...] Sem dúvida a renúncia do Sr. Jânio Quadros trouxe de volta ao poder o bando que pensávamos ter expelido definitivamente da vida política brasileira e agora com a séria agravante que é o recrudescimento da ameaça totalitária. ${ }^{5}$

O fato é que, entre grandes parcelas das classes dominantes, militares conservadores e alguns setores médios do Brasil, há muito se acreditava que João Goulart era, no mínimo, um simpatizante dos comunistas. Afinal, "Jango era o líder da ala esquerda do PTB e um dos principais responsáveis pela transformação do partido getulista, concebido originalmente como dique contra o comunismo, em aliado do PCB” (MOTTA, 2002, p. 234). O próprio PTB não estava a salvo das identificações feitas pelos setores mais conservadores. Na década de 1960, foi comum a associação deste partido ao comunismo, cunhando-se o termo petebismocomunismo, muito utilizado pelo IBAD e pelos setores conservadores da Igreja Católica. Na Revista Ação Democrática, o IBAD afirma que:

De 1950 para cá a aliança entre o PTB e o comunismo só tem feito avançar e a primeira meta desse movimento já se acha à vista: a implantação do socialismo que fará do Brasil a Cuba da América do Sul. A meta seguinte - que poderá ser atingida simultaneamente - é a escravidão totalitária.

Não temos dúvida que a maior parte dos brasileiros com cujos votos o senhor Jango Goulart se elegeu vice-presidente da República - e agora seu presidente, por força da Constituição - não teriam votado nele se tivessem visto com clareza o que Jango representa. ${ }^{6}$

\footnotetext{
5 "Diante da ascensão totalitária“. Revista Ação Democrática, v. 3, n. 31, dez. 1961.

6 "Diante da ascensão totalitária". Revista Ação Democrática, v. 3, n. 31, dez. 1961. P. Final.
} 
Para o Jornal Semana Católica, da Arquidiocese de Salvador:

[...] o PTB, em assembleia partidária, declarou a necessidade de insistir junto aos eleitores em que nada tem o partido com a esquerda. Daí a dupla responsabilidade do eleitorado democrático, não se deixar iludir por tais mentiras o (sic) não se abster de votar ${ }^{7}$, porquanto os outros, os comunistas, esses não faltarão às urnas em hipótese alguma. Considerem os brasileiros o seu voto nas próximas eleiçôes como um ato religioso, como uma resposta ao repto de maus, lançado contra Deus e contra o Brasil. ${ }^{8}$

O temor acarretado pela possibilidade da ascensão de Goulart ao poder e que esta pudesse significar o fortalecimento dos comunistas, associado à frustração dos conservadores pelo possível retorno do getulismo, levou a que se tentasse impedir a posse (MOTTA, 2002, p. 234). A esta se opuseram os três ministros militares ${ }^{9}$ de Jânio, que se declararam contrários à posse de João Goulart. Lançaram, em nome das Forças Armadas do Brasil, um manifesto à nação onde expuseram o porquê desta decisão. $\mathrm{Na} 28^{\mathrm{a}}$ sessão do Congresso Nacional, iniciada às $21 \mathrm{~h}$ do dia 30 de agosto de 1961, o Deputado Neiva Moreira iniciou a leitura deste manifesto (SILVA, 1975, p. 85), eis um trecho deste documento:

No cumprimento de seu dever constitucional [...] as Forças Armadas do Brasil, através da palavra autorizada de seus Ministros, manifestaram à Sua Excelência o Senhor Presidente da República, como já foi amplamente divulgado, a absoluta inconveniência, na atual situação, do regresso ao País do Vice-Presidente Sr. João Goulart [...] Já ao tempo em que exercera o cargo de Ministro do Trabalho, o Sr. João Goulart demonstrara, bem às claras, suas tendências ideológicas [...] E não menos verdadeira foi a ampla infiltração que, por essa época, se processou no organismo daquele Ministério [...] de ativos e conhecidos agentes do comunismo internacional, além de incontáveis elementos esquerdistas. (SILVA, 1975, p. 86)

\footnotetext{
${ }^{7}$ Eleiçōes a serem realizadas em alguns estados brasileiros, dentre os quais, a Bahia.

8 "A palavra de ordem é afirmar que o comunismo no Brasil não existe". Jornal Semana Católica, p. 4, 16 set. 1962.

${ }^{9}$ Sílvio Heck, Ministro da Marinha; Mal. Odílio Denys, Ministro da Guerra e Brig. Grün Moss.
} 
Além disso, como agravante, no momento da renúncia de Jânio Quadros, Jango encontrava-se em visita oficial à China, fato que só fortaleceu sua associação ao comunismo. Num outro trecho do Manifesto à Nação, este fato é ressaltado pelos Ministros Militares já mencionados:

No cargo de Vice-Presidente, sabido é que sempre usou sua influência em animar e apoiar, mesmo ostensivamente, manifestações grevistas promovidas por conhecidos agitadores. E, ainda há pouco, como representante oficial, em viagem à URSS e à China comunista, tornou clara e patente sua incontida admiração ao regime destes países, exaltando o êxito das comunas populares. (SILVA, 1975, p. 87)

Jango assumiu o governo brasileiro no clima da crise política que se instaurou no Brasil após a renúncia de Jânio Quadros. As já mencionadas representações que dele se faziam, aliado ao fato deste pertencer ao partido de oposição, o PTB, tornaram ainda mais conturbado o processo da sua posse, constitucionalmente legal.

Após uma série de idas e vindas em intermináveis sessões diárias e noturnas das duas casas do Congresso Nacional - Câmara e Senado - bem como sucessivas reuniōes entre o então presidente Ranieri Mazzilli e os ministros militares divergentes, chegou-se a uma "solução": adotar-se-ia o sistema parlamentarista. Essa solução agradou, em especial, àqueles que tinham Jango como uma ameaça, pois, no sistema Parlamentarista, o Executivo não tinha todos os poderes, cabendo as decisões ao Congresso Nacional e ao gabinete dos Ministros. Jango poderia, portanto, ser vigiado na sua suposta intenção de transformar o país em uma república sindicalista.

Esse medo de um Jango amigo dos comunistas tem sua origem durante a atuação deste enquanto Ministro do Trabalho de Getúlio Vargas, entre os anos de 1953 e 1954. Naquele contexto, além de aproximar o Ministério do Trabalho dos próprios trabalhadores, estimulando as denúncias contra as infrações cometidas contra a Consolidação das Leis do Trabalho (CLT), Jango cogitou a extensão da legislação trabalhista ao campo, chegando a falar em Reforma Agrária (SILVA, 1975, p. 50), para desespero e insatisfação de grande parte das classes dominantes daquele período, em especial, os grandes latifundiários. Por fim, com a proposta de aumento do salário mínimo para cem por cento, no ano de 1954, devido à elevação do custo de vida, Jango decretou o ponto final no seu ministério, pedindo demissão. 
Jango foi associado ao comunismo, e este, por sua vez, era visto como a versão política do ateísmo e da negação dos valores cristãos. O objetivo do comunismo, nessas representações, era a destruição da democracia, pondo um fim aos pilares da sociedade cristã: Deus, Pátria e Família (MOTTA, 2002). Conforme afirmação de Motta (2002, p. 276), "desta forma, o temor ao comunismo foi o "cimento" da mobilização antigoulart, o elemento que propiciou a unificação de setores heterogêneos numa frente favorável à derrubada do Presidente".

Essas representaçóes alcançavam grande parte dos setores médios - pois o comunismo atingia o mito da ascensão social, tão desejado por estes setores - e, dentre estes, principalmente, as mulheres. Do ponto de vista das mulheres pertencentes às fraçôes da classe dominante e aos grupos dos setores médios cuja educação, em geral, prezava por valores morais cristãos como a família, a pátria e a religião - o comunismo não era compreendido somente como um sistema político e econômico, mas, mais que isso, era uma filosofia que objetivava substituir a religião cristã, negando-a, e aos pilares desta sociedade (MOTTA, 2002; SIMÔES, 1985).

A representação do comunismo como inimigo absoluto não derivava apenas do medo que conquistasse as classes trabalhadoras. A questão central, na ótica dos responsáveis católicos [...] é que a nova doutrina questionava os fundamentos básicos das instituições religiosas. O comunismo não se restringia a um programa de revolução social e econômica. Ele se constituía numa filosofia, num sistema de crenças que concorria com a religião em termos de fornecer uma explicação para o mundo e uma escala de valores, ou seja, uma moral. A filosofia comunista opunha-se aos postulados básicos do catolicismo [...]. (MOTTA, 2002, p. 20)

Durante os anos de 1962 e 1963, o Governo Goulart - cuja forma foi redefinida, pelo plebiscito realizado em 1963, como presidencialista - foi alvo de ataques anticomunistas, com tensōes cada vez maiores nos círculos militares. Após Jango ter recebido a faixa presidencial, em 1963, os acontecimentos desenrolaram-se muito rapidamente. Por um lado, os setores à esquerda e os movimentos sociais - em especial, os sindicais - faziam pressão para que fosse acelerada a implementação das Reformas de Base, em especial a Reforma Agrária. 
Os setores conservadores, por outro lado, respondiam também pressionando ao governo para que fossem garantidas suas benesses de classe. Nessa "corda bamba", Jango resolveu optar por ampliar e garantir o apoio da sua base, a classe trabalhadora, que, naquele momento, mostrava-se desejosa pela manutenção do Presidente no poder. Os setores da classe dominante reagiram, sintetizando todas as tensões do período na organização da Campanha de derrubada do Presidente João Goulart, tendo como alvos prioritários de convencimento os setores médios.

Além do apoio dado pelo complexo IPES/IBAD, também houve o envolvimento de grupos dos Estados Unidos nesta campanha, através do apoio logístico (seja no envio de armas, seja no fornecimento de livros e outros aparatos ideológicos) e de financiamento, através de suas figuras públicas e, inclusive, do próprio Governo estadunidense.

\section{As 'donas' saem às ruas}

Passado menos de um ano após a renúncia de Jânio Quadros, a exploração do medo do comunismo pelos "industriais do anticomunismo" já rendia frutos. Suas consequências eram notáveis e surpreendiam, em especial, pois tinha ares de novidade: algumas mulheres passaram a ocupar um espaço político destacado na sociedade brasileira (SIMÕES, 1985, p. 9) quando aderiram à Campanha de desestabilização. Passaram, de acordo com Solange Simões, a ocupar a primeira página de noticiários políticos em consequência da promoção de atividades em praças públicas, com ampla cobertura nas rádios.

Essas ações das mulheres na campanha de desestabilização acompanharam o desenrolar da conspiração contra o presidente Jango, organizada, em especial, nos estados de Minas Gerais, São Paulo, Guanabara e Rio de Janeiro. Podemos afirmar, inclusive, que foi fundamental a presença de mulheres nesta campanha, pois assim esta ganhou um tom de espontaneidade e, além disso, legitimou as ações das Forças Armadas diante da necessidade de uma intervenção militar - o que findou por acontecer.

Conforme a afirmativa de Solange Simões (1985, p. 36), "essa mobilização atendia, portanto, a um objetivo principal: viabilizar e justificar o golpe enquanto resposta a um espontâneo e legítimo apelo popular". Visava, sobretudo, mobilizar os setores médios, posto que a classe trabalhadora encontrava-se mais afeita às propostas lançadas pelo nacional-reformismo de João Goulart. Assim, o complexo IPES/IBAD, já antes mencionado, não poupou esforços para que este objetivo fosse concretizado, dando total assistência - através dos 
assessores masculinos - aos grupos femininos que se organizaram naqueles primeiros anos da década de 60.

Nos Estados de São Paulo, Rio de Janeiro, Guanabara, Minas Gerais, Ceará e Pernambuco, as mulheres atuaram de forma institucionalmente organizada em entidades como a Campanha da Mulher pela Democracia (CAMDE), a Liga da Mulher Democrata (LIMDE) e a União Cívica Feminina (UCF) (Cf. FICO, 2004b; SIMÕES, 1985). O diferencial daquela participação foi o alto nível de organização política destas mulheres, que não apareciam isoladamente, tinham papéis definidos para direção e concepções próprias de sua atuação. Nessas concepçôes, a presença do discurso anticomunista e do conservadorismo cristão era fundamental, pois, como veremos, eram utilizados como elementos arregimentadores.

Quanto à atuação destes grupos femininos, de acordo com Simões, estava dividida entre açôes de convencimento e ações de rua. Para as primeiras, os grupos utilizavam alguns recursos, tais como a promoção de reuniōes com mulheres e assessores das organizaçōes femininas visando a tomada de decisōes quanto aos rumos da campanha antigoulart; a distribuição de cartas e panfletos explicativos contra o comunismo visando a difusão dos motivos que justificavam as ações anticomunistas (FICO, 2004b, p. 41); e a promoção de sessões de filmes editados pelo IPES, cujo objetivo era tocar emocionalmente aos que assistiam para o perigo que representava a entrada do comunismo no Brasil e para a necessidade de defender a pátria, a religião e a família ameaçadas. O objetivo geral destas primeiras ações era de convencer as pessoas do perigo comunista e arregimentá-las para a campanha de desestabilização e para a Marcha da Família.

Quanto às ações de rua, foram organizadas através de diversas manifestações cujo lema em geral era "a defesa da democracia e contra o comunismo ateu”. O ponto alto destas mobilizações foram as Marchas da família com Deus e pela liberdade que aconteceram em diversos estados do Brasil. A partir da observação da estratégia utilizada nestas ações, podemos afirmar que as ações de rua complementaram a campanha de arregimentação anterior, servindo como uma espécie de confirmação da força política do grupo que as promoviam.

Todo o aparato para essas açôes que compunham a campanha antigoulart foi financiado diretamente pelo Complexo IPES/IBAD. A intenção deste era primeiramente, desgastar o governo de João Goulart e o nacional-reformismo, visando conter o crescimento do comunismo no país. Para tal, a campanha que envolvia diretamente os grupos femininos visava: 
Impedir a solidariedade das classes trabalhadoras, conter a sindicalização e mobilização dos camponeses, apoiar clivagens ideológicas de direita na estrutura eclesiástica, desagregar o movimento estudantil e bloquear as forças nacional-reformistas no Congresso. (SIMÕES, 1985, p. 26)

E, além disso, mobilizar os setores médios.

Do ponto de vista ideológico, além da influência do conservadorismo cristão, do discurso anticomunista e do comprometimento com seus interesses de classe, as mulheres exerciam seus papéis fundamentados pelo discurso do "Maternalismo", um forte elemento construído a partir da identidade de gênero: apareceram na cena política como donas de casa, esposas e mães que viviam para a manutenção do espaço privado, para a defesa da sua família e para o lar. Este discurso foi amplamente utilizado pelos setores da Igreja Católica, e as mulheres foram instigadas a lutar contra o comunismo, em função das ameaças que este proporcionava, em especial, às famílias cristãs:

Centenas de mães fluminenses dirigiram-se ao presidente João Goulart, em mensagem por intermédio de "O Globo", pedindo-lhe [que] modifique as linhas perigosas de seu governo para que reine a tranqüilidade no país. "Cremos que a mãe do próprio Presidente da República há de juntar a sua voz a nossa, pedindo as soluções que o Brasil exige, mas na justiça cristâ, na liberdade da Pátria, sem vender o Brasil aos comunistas".

Frisam a seguir: "Que o presidente da República saiba que nós, mães, já sabemos que a falta de produtos no país é um Plano diabólico para exigir do povo faminto que aceite o comunismo como tábua de salvação. Queremos um Brasil tranqüilo, próspero e sempre nosso. Queremos, com tranqüilidade, ensinar aos nossos filhos o amor de Deus e da Pátria, contra os materialistas traidores", concluem. $^{10}$

10 "Mães apelam ao presidente: 'modifique as linhas perigosas de seu governo'”. Jornal Semana Católica, p. 1, 22 jul. 1962. 
O discurso do maternalismo surgiu da construção cultural sobre as diferenças biológicas, ou seja, as sociedades - dentro dos seus aspectos sócio-culturais peculiares - organizam e orientam os papéis que serão assumidos por homens e mulheres, partindo das características biológicas destes grupos. O que não significa que esses papéis sejam naturais, pelo contrário, são naturalizados, pelos homens e pelas mulheres, dentro de relações de poder - as relações de gênero.

No caso das mobilizaçôes aqui estudadas, em se tratando de um universo majoritariamente católico/cristão, ao conceito de maternalismo integra-se o conceito de marianismo. Este, como aponta a autora Zaíra Ary (2000), compreende uma carga de valores e estereótipos que visam enquadrar as mulheres numa imagem perfeita para o que é pregado no discurso majoritário cristão, da Virgem Maria, o modelo católico/cristão que toda mulher deveria seguir.

Elas estavam convencidas da necessidade de irem às ruas lutar em defesa da democracia, supostamente ameaçada pelo comunismo, mas, mais que isso, sabiam que essa era uma função a ser exercida pelas mulheres, ou melhor, pelas mães, filhas, noivas e esposas do Brasil. "Elas se lançaram na esfera pública a partir de sua condição de seres privados - foi como 'mulheres-mães-donas-decasa' que aquelas mulheres se apresentaram publicamente” (ARY, 2000, p. 10). Para elas, cabia às mulheres resguardar os pilares que garantem a manutenção de qualquer sociedade cristã: "Deus, pátria e família", e, para que nada de mal acontecesse a essa sociedade, valeria a pena "sair dos seus lares" e ir às ruas cumprir o "seu papel".

\section{As senhoras soteropolitanas e a Marcha da Família}

Em Salvador, já nos primeiros meses de 1963, início da gestão do governador Antonio Lomanto Júnior - gestão dos partidos opositores PTB e UDN - setores conservadores da Igreja Católica, contando com a presença de diversas senhoras soteropolitanas, organizaram suas primeiras ações de rua com a finalidade de desestabilizar Jango e conter suas reformas de base. Dentre as manifestações de maior visibilidade, destacamos a procissão de Corpus Christi, realizada em 1963 e presidida pelo bispo auxiliar Dom Walfrido Vieira, considerada a maior procissão já observada, até aquele momento, em Salvador (FERREIRA, Muniz. 2003). Esta foi convocada pela Cruzada do Rosário em Família - organização de cunho internacional fundada em 1945, nos Estados Unidos - e liderada pelo padre irlandês Payton, tendo como mote a "apreensão dos católicos em face à ameaça comunista". (FERREIRA, Muniz. 2003, p. 6) 
Realizadas em diversos Estados brasileiros, as Cruzadas do rosário consistiram numa espécie de ensaio para as Marchas da família. Seu objetivo era tocar emocionalmente a todos os presentes através da manipulação de símbolos religiosos que envolviam, em especial, os apelos de Nossa Senhora de Fátima e a reafirmação da necessidade da defesa dos 'valores sagrados' da sociedade cristã - conforme vimos, Deus, pátria e família contra o comunismo.

Outra manifestação organizada em Salvador pelo padre Payton, naquele ano, foi a panfletagem feita pelas mulheres da CAMDE ${ }^{11}$ que tinha por objetivo "conclamar as famílias a enfrentarem 'o inimigo comunista' que é a negação da liberdade, da justiça e da paz”. (FERREIRA, Muniz. 2003, p. 6)

$\mathrm{Na}$ Bahia, apesar da existência de várias organizações de mulheres de setores médios, em sua grande maioria de caráter filantrópico ou emancipacionista como o exemplo da Federação Bahiana pelo Progresso Feminino, criada em abril de 1931, não observamos uma articulação institucionalizada com esse movimento nacional no período que antecedeu ao golpe civil-militar de 1964. Esta articulação só ocorreu através da Deputada Estadual Ana Oliveira, do Partido Libertador (PL), que, após o sucesso da manifestação paulista, em 19 de março de 1964, será a primeira mulher de destaque na Bahia a empenhar-se em conclamar as baianas para se integrarem a esta mobilização nacional, conforme noticiou o jornal $A$ tarde:

A deputada Ana Oliveira anuncia que vai iniciar um movimento de mulheres baianas em defesa da democracia e das instituiçôes vigentes e contra o comunismo, a exemplo do que já acontece em Minas, Rio e São Paulo. Já na próxima terça-feira, fará um discurso na assembleia lançando o movimento e depois conclamará as mulheres de todo Estado a se unirem. Já conta com a adesão antecipada de centenas de mães de família, senhoras de todas as classes e de todas as idades. ${ }^{12}$

\footnotetext{
${ }^{11}$ Campanha da Mulher Democrática (CAMDE) é uma entidade feminina de São Paulo, lançada no ano de 1962, no Rio de Janeiro, com o objetivo de lutar contra a infiltração comunista no Brasil, em defesa da democracia. Para mais informaçōes. (SIMŌES, 1985, p. 28)

12 “Discurso de Ana Oliveira”. A Tarde, p. 3, 21 mar. 1964.
} 
Nos dias que se seguiram, Ana Oliveira utilizou várias vezes a tribuna da Assembleia Legislativa para convocar as mulheres, sempre alertando para o risco do avanço comunista. Mas foi somente após o golpe civil-militar de 1964 que as mulheres baianas de classe média se organizaram e trataram logo de manifestar seu apoio ao novo regime. Já no dia 06 de abril, com uma matéria intitulada Professoras solidárias com o Exército, o jornal A Tarde noticiou que "Comissão de professoras presta homenagem ao General Manoel Mendes Pereira, comandante da VI região militar, pelo revigoramento de democracia brasileira". ${ }^{13}$

No dia seguinte, o referido jornal trazia com destaque a notícia da homenagem realizada pelas mulheres ao General Manoel Mendes Pereira, comandante da VI região militar e "por seu intermédio, aos chefes das guarniçôes da Marinha e da Aeronáutica”. O discurso proferido por Suzana Imbassahy da Silva nos dá claramente uma ideia da composição social dessas mulheres e de seus interesses políticos:

Aqui estamos nós, uma delegação de senhoras cristãs, mães de famílias, médicas, professoras, funcionárias, mas, antes de tudo, mulheres baianas que também têm seu passado de glórias vinculado a todos os fatos da história do Brasil, mulheres que se orgulham de serem descendentes de Maria Quitéria, mulher-soldado, e sóror Joana Angélica, a mártir; mulheres baianas que também sofreram e vibraram, dentro de seus lares, acompanhando cheias de ansiedade toda essa maravilhosa campanha que se processou com tanta eficiência e tanta paz que se nos afigura milagre de Deus por intermédio das forças armadas. [...] porque afastou de nós, mulheres cristãs, esse vento mau que soprou pelo Brasil, "vento de pânico e de discórdia", que ameaçou desviar a terra brasileira da sua tradição de cordialidade e de 'solução pacífica na superação das suas crises históricas'. ${ }^{14}$

A Comissão organizadora da Marcha reuniu-se no requintado Club de Bridge da Bahia, para definir o roteiro e os encaminhamentos necessários. Os

\footnotetext{
13 "Professoras solidárias com o Exército". A Tarde, p. 2, 6 abr. 1964.

14 "O agradecimento da mulher bahiana". A Tarde, p. 2, 7 abr. 1964.
} 
jornais destacam a presença de importantes senhoras e representantes do Clero $^{15}$. Nessa reunião, foi elaborada a Proclamação da Marcha, amplamente divulgada:

Baianos. Homens e mulheres, velhos e moços, de todas as classes, de todas as profissões, de todos os credos de todas as religiōes, não esperem convite para participarem da grande passeata no dia 15 (quarta-feira), a partir da Praça da Sé às quinze horas, com o fim de expressar o nosso sentimento de agradecimento a Deus - nosso grande General - e as forças armadas pelo alívio que trouxe ao coração de todos os brasileiros e particularmente, à família baiana. Não espere convite pois a festa tem dono, é sua, é minha, é nossa, é da Bahia. ${ }^{16}$

Assinava a proclamação: "A mulher baiana".

No dia 15 de abril, a partir das 14 horas, começou a concentração na Praça Municipal. Após a celebração do solene “Te-Deum”, na Catedral Basílica, a multidão dirigiu-se ao Campo Grande,

[...] formando então uma impressionante torrente de homens, mulheres, crianças, que entoando hinos patrióticos e religiosos, davam vivas às Forças Armadas e à Democracia. Bandeiras do Brasil e da Bahia, faixas alusivas à redemocratização do país, delegações de outros Estados e do interior baiano, representantes de dezenas de entidades, civis e religiosas, grupos representativos das Forças Armadas, bandas de música e o povo vibrando constituíam o conjunto da indescritível passeata [...] Os acordes do Hino Nacional Brasileiro e de marchas patrióticas comoveram até as lágrimas de milhares de pessoas $[\ldots]^{17}$

\footnotetext{
15 [...] da reunião participaram inúmeras senhoras baianas, dedicando-se entre outras, D. Maria do Carmo Cabral, esposa do coronel Francisco Cabral, Secretário de Segurança Pública, que representou D. Hildete Lomanto, esposa do Governador do Estado e D. Maria Helena Almeida, esposa do Sr. Adélio Almeida. O Clero baiano esteve mais uma vez representado pelos Srs. Manoel Soares e Walter Magalhães. Falando em nome do Cardeal da Silva, os dois sacerdotes aprovaram a sugestão apresentada na reunião, segundo a qual os sinos das matrizes de salvador deveriam repicar festivamente, lembrando aos fiéis e aos cristãos em geral o grande significado da Marcha da Família. (Ver: “'Marcha da Família’ na Bahia já tem programa aprovado”. Jornal da Bahia, p. 5, 8 abr. 1964)

16 “O Programa da Passeata”. A Tarde, p. 4, 9 abr. 1964.

17 "Marcha: Impressionante demonstração de civismo". Jornal da Bahia, p. 1, 16 abr. 1964.
} 
Esta foi a maior manifestação baiana de apoio aos militares. Tendo sido apoiada diretamente pela Prefeitura Municipal ${ }^{18}$, pelo Governo do Estado ${ }^{19}$ e por diversos setore ${ }^{20}$ a Marcha contou com cerca de 400 mil pessoas ${ }^{21}$. No dia seguinte, em grande manchete, o jornal $A$ Tarde anunciava em primeira página "Marcha foi apoteose da vitória". Como um dos resultados deste grandioso acontecimento público, os grandes jornais da capital baiana noticiaram a abertura de uma sede da União Cívica Feminina (UCF) em Salvador, cuja presidência ficou em mãos de Dona Edith da Gama e Abreu, conhecida feminista baiana, fundadora da Federação Bahiana pelo Progresso Femini$\mathrm{no}^{22}$. Para além deste estudo que realizamos, fica a possibilidade de avaliarmos as conseqüências desta mobilização para o cotidiano político e social de Salvador, em especial, para as soteropolitanas, pesquisa que realizaremos posteriormente.

\footnotetext{
${ }^{18} \mathrm{O}$ apoio da prefeitura, através do seu prefeito, foi amplamente divulgada na imprensa:Em entendimento com a deputada Ana Oliveira, o prefeito Antonino Casaes declarou que a prefeitura dará todo o apoio à realização da passeata, mandando, inclusive, armar no Campo Grande, o grande palanque que foi utilizado [...] durante a Cruzada do Rosário em família [...]. (Ver: "Passeata da Sé ao Campo Grande será sexta-feira". A Tarde, p. 4, 8 abr. 1964). A deputada Ana Oliveira comunicou às senhoras baianas que estão preparando a "Passeata da Vitória" que o prefeito Antonino Casaes lhe garantiu todo apoio da prefeitura para a mesma [...] ofereceu [...] tudo que estiver a seu alcance. (Cf. "Prefeitura apóia passeata", A Tarde, p. 3, 9 abr. 1964).

${ }^{19}$ Será feriado escolar amanhã, a fim de que os alunos das várias escolas possam participar da "Marcha...”, segundo portaria baixada ontem pelo Secretário de Educação que recomenda ainda não devem os colegiais aparecerem na passeata uniformizados. (Cf. "Feriado escolar amanhã para comemorar a Marcha da Família”. Jornal da Bahia, p.5, 14 abr. 1964)

${ }^{20}$ Além da massa popular que deverá acompanhar a passeata, por iniciativa própria, diversas entidades já hipotecaram irrestrito apoio ao desfile cívico, entre elas, destacando-se: A comunidade batista [...], todos os sindicatos democráticos [...], instituições religiosas, ordens terceiras parlamentares, Rotary clube, Lions clube, toda a Maçonaria, Liga Bahiana contra o analfabetismo, Petrobras, Fuzileiros navais, Clubes sociais e muitas outras. [...] Tendo a associação comercial pedido aos seus membros que fechem seus estabelecimentos comerciais [...] O prefeito Antonino Casaes assinou decreto considerando ponto facultativo o turno vespertino, o mesmo tendo feito a assembléia legislativa. [...] O governador também vai declarar ponto facultativo no expediente da tarde [...] "Além de colocar seus navios para o transporte de pessoas residentes no Recôncavo, durante a manhã, a navegação Bahiana colocará, também, todas suas embarcações no porto, na hora do início do desfile [...] (Cf. "Sob o repicar dos sinos, baianos agradecerão a Deus". A Tarde, p. 3, 13 abr. 1964). O Presidente da Federação das Indústrias, Sr. Pedro Ribeiro, formulou apelo aos industriais baianos no sentido de encerrar as atividades de suas empresas às 14 horas de amanhã, a fim de possibilitar o comparecimento de seus operários a 'Marcha da Família' [...] Por outro lado, determinou o Presidente da Federação das Indústrias a decretação de ponto facultativo nos órgãos ligados ao Serviço Social da Indústria e Serviço Nacional de aprendizagem industrial a fim de que seus funcionários possam também participar da 'Marcha da Família.' [...] programada para amanhã em nossa capital. (Ver: "Comércio fechará”. Jornal da Bahia, p. 5, 14 abr. 1964)

${ }^{21}$ Eis a ordem em que se apresentaram na 'Marcha da família...', integrantes da passeata: 1) Banda de música do exército; 2) Autoridades civis, militares e eclesiásticas; 3) Comissão central organizadora da passeata; 4) Grupamento de professores e alunos do curso primário; 5) Grupamento de professores e alunos do curso secundário; 6) Diretórios estudantis, que se incorporaram na praça Castro Alves; 7) Banda de música da Polícia Militar 8) Delegações do interior; 9) Delegações esportivas; 10) Outras entidades, inclusive regionais. Desfilaram na grande Marcha da família..., entre outros, notados pela reportagem: Conferentes e Consertadores de porto de Salvador; Colégio da Polícia Militar do Estado; Corpo de Bombeiros; Irmandade de São Francisco; Ginásio Irmã Dulce; Círculo Operário da Bahia; Evangelistas; Maçonaria; Instituto de música da Bahia tendo o vereador Cosme de Farias encerrado a passeata em
} 


\section{Considerações finais}

Em alguns estados brasileiros, as Marchas da Família com Deus pela Democracia e pela Liberdade, estavam inseridas na campanha de desestabilização de João Goulart, que contava com a liderança expressiva de mulheres (MOTTA, 2005). Em Salvador, conforme vimos, ela ocorreu após o golpe civil-militar de 1964, constituindo-se não mais como marcha de arregimentação - conforme definição de Solange de Deus Simões - mas, sim, uma marcha de apoio.

Por fim, para não perder de vista que nosso artigo concentra-se na análise de um movimento de mulheres, ratificamos que nem todos estes movimentos se inserem no contexto das lutas feministas ${ }^{23}$. Conforme vimos, existem mulheres organizadas que não questionam seus lugares sociais de gênero enquanto sujeitos na sociedade e não têm a perspectiva de transformação na condição de subalternidade da mulher (COSTA; SARDENBERG, 1994), pelo contrário, muitas vezes utilizam-se dessa subalternidade e de um conjunto de estereótipos, sem nenhuma - ou com pouca - perspectiva crítica quanto ao papel destinado à mulher na sociedade, para justificar sua ação política ou suas demandas, como foi o caso do movimento de mulheres pela desestabilização de Jango. Outro caso exemplar, muito próximo ao nosso, foi o movimento sufragista de inícios do século XX que colocava a necessidade da autonomia política das mulheres como um dos requisitos para o melhor exercício do seu papel de mãe.

Entretanto, também não podemos esquecer que o movimento de mulheres contempla uma enorme diversidade de formas de organização, objetivos e ideologias. Neste sentido, Malyneux (2003, p. 225) afirma que "um movimento de mulheres não precisa ter uma única expressão organizativa e pode

companhia de um grupo de crianças, das quais é mantenedor. (Ver: "Integrantes do desfile". Jornal da Bahia, p. 5, 16 abr. 1964)

${ }^{22}$ Apesar desta participação final de uma feminista, ressaltamos que a Marcha da família, muito embora um movimento de mulheres, não pode ser caracterizado como uma mobilização feminista, pois este não questionava os lugares sociais de gênero estipulado para homens e mulheres.

${ }^{23} \mathrm{O}$ movimento feminista, apesar de inserir-se no movimento mais amplo de mulheres, distingue-se por defender os interesses de gênero das mulheres, por questionar os sistemas culturais e políticos construídos a partir dos papeis de gênero historicamente atribuídos às mulheres, pela definição da sua autonomia em relação a outros movimentos, organizaçôes e o Estado e pelo princípio organizativo da horizontalidade, isto é, da não existência de esferas de decisões hierarquizadas (ÁLVAREZ, 1990, p. 23). Segundo Costa e Sardenberg (1994) o feminismo pode se manifestar enquanto uma doutrina ou movimento social, cujos sujeitos principais são em sua maioria mulheres que acreditam na luta por igualdade e liberdade, questionando a hierarquização nas relações sociais entre homens e mulheres. "O feminismo pressupõe o surgimento de uma consciência de gênero feminina" (COSTA; SARDENBERG, 1994, p. 83), ou melhor, consciência feminista que se daria em âmbito coletivo refletindo nas praticas sociais entre homens e mulheres. "A consciência de gênero é a forma como essas experiências são tratadas em termos culturais: encarnadas em tradiçōes, sistemas de valores, idéias e formas institucionais“. (COSTA; SARDENBERG, 1994, p. 84) 
caracterizar-se por uma diversidade de interesses, formas de expressão e localizações espaciais". Pode inclusive apresentar "posições e objetivos políticos distintos e, mesmo quando as mulheres se organizam de maneira autônoma, nem sempre atuam de maneira autônoma na defesa dos seus interesses de gênero" (MALYNEUX, 2003, p. 230).

Ou seja, a multiplicidade do movimento de mulheres pode abarcar, sem contradiçōes, movimentos feministas e que possuem uma visão crítica quanto aos lugares sociais de gênero, mas também pode conter mobilizações como as Marchas da família que, apesar de arregimentar um amplo número de mulheres, foi organizado com base na manutenção das mulheres na condição de mães, donas de casa e esposas exemplares, bem como buscou preservar o lugar social a elas destinado: a família.

\section{REFERÊNCIAS}

ÁLVAREZ, Sonia. Engendering democracy in Brasil: women's moviments in transitión politics. Pinceton: Princeton University, 1990.

ARY, Zaíra. Masculino e feminino no imaginário católico: da Ação Católica à Teologia da Libertação. São Paulo: Annablume; Fortaleza: Secult, 2000.

COSTA, Ana Alice A.; SANTANA, Ediane Lopes; SOBRAL, Rebeca. As mulheres e as marchas da Família com Deus pela democracia e pela liberdade na Bahia. In: MOTTA, Alda Britto da; AZEVEDO, Eulália Lima; GOMES, Márcia Queiroz de Carvalho. Reparando a falta: dinâmica de gênero em perspectiva geracional. Salvador: NEIM/ UFBA, 2005. (Coleções Baianas, 10). p. 135-151.

COSTA, Ana Alice A.; SARDENBERG, Cecília Maria. Feminismos, feministas e movimentos sociais. In: BRANDÃO, Maria Luiza; BINGEMER, Maria Clara (Org.). Mulher e relações de gênero. São Paulo: Loyola, 1994.

DREIFUSS. René Armand. 1964: a conquista do Estado: ação politica, poder e golpe de classe. 3. ed. Petrópolis, RJ: Vozes, 1981.

FERREIRA, Marieta de Moraes (Coord.). João Goulart: entre a memória e a história. Rio de Janeiro: FGV, 2006.

FERREIRA, Muniz Gonçalves. O Golpe de Estado de 1964 na Bahia. 2003. Disponível em: <http://www.fundaj.gov.br/licitacao/observa_bahia_02.pdf>. Acesso em:

FICO, Carlos. Além do golpe: versões e controvérsias sobre 1964 e a ditadura militar. Rio de Janeiro: Record, 2004c.

. Com o rosário na mão. Revista Nossa História, Rio de Janeiro, v. 1, n. 5, p. 40-

43, mar. 2004 b. 
. Versões e controvérsias sobre 1964 e a Ditadura Militar. Revista Brasileira de História, São Paulo, v. 24, n. 47, 2004a. Disponível em: <www.scielo.br>. Acesso em: 20 jul. 2006.

GASPARI, Elio. As ilusões armadas: a ditadura envergonhada. São Paulo: Companhia das Letras, 2002.

MOLYNEUX, Maxine. Movimientos de mujeres en América Latina: un estudio teórico comparado. Madrid: Cátedra: Universidad de Valencia, 2003.

MOTTA, Aricildes de Moraes. 31 de março de 1964: história oral do exército. Rio de Janeiro: BIBLIEX, 2005. Tomos 11, 1213 e 14.

MOTTA, Rodrigo Patto Sá. Em guarda contra o perigo vermelho: o anticomunismo no Brasil. São Paulo: Perspectiva: Fapesp, 2002.

PRESOT, Aline Alves. As Marchas da Família com Deus pela liberdade e o Golpe de 1964. Rio de Janeiro, 2004. Dissertação (Mestrado em História Social) - Universidade Federal do Rio de Janeiro.

SCOTT, Joan Walash. Gender: an useful category of historical analyses: Gender and politics of history (gênero: uma categoria útil para análise histórica). New York: Columbia University, 1989.

História das mulheres. In: BURKE, Peter (Org.). A escrita da história: novas perspectivas. São Paulo: UNESP, 1992.

SILVA, Hélio. 1964: golpe ou contragolpe? Rio de Janeiro: Civilização Brasileira, 1975.

SIMÕES, Solange de Deus. Deus, pátria e família: as mulheres no golpe de 1964. Petrópolis, RJ: Vozes, 1985.

SOIHET, Rachel. História das Mulheres. In: CARDOSO, Ciro Flamarion; VAINFAS, Ronaldo (Org.). Dominios da história: ensaios de teoria e metodologia. Rio de janeiro: Elsevier, 1997.

STARLING, Heloisa Maria Murgel. Os senhores das gerais: os novos inconfidentes e o golpe de 1964. 3. ed. Petrópolis, RJ: Vozes, 1986.

TOLEDO, Caio Navarro de. 1964: o golpe contra as reformas e a democracia. Revista Brasileira de História, São Paulo, v. 24, n. 47, 2004. Disponível em: <www.scielo.br>. Acesso em: 27 set. 2006.

.; OLIVEIRA, Marcus Roberto. A marcha, o terço e o livro: catolicismo conservador e ação política na conjuntura do golpe de 1964. Revista Brasileira de História, Sã Paulo, v. 24, n. 47, 2004. Disponível em: < www.scielo.br>. Acesso em: 20 jul. 2006. 



\section{2 \\ Protestantes e o governo militar: convergências e divergências}

Elizete da Silva ${ }^{1}$

Todo homem esteja sujeito às autoridades superiores: porque não há autoridade que não proceda de Deus.

(Bíblia Sagrada: Romanos 13: 1)

Pretendemos, neste artigo, abordar as relações que a Denominação ${ }^{2} \mathrm{Ba}-$ tista e a Igreja Presbiteriana do Brasil estabeleceram com os governos militares após o golpe de 1964. Tradicionalmente, os evangélicos mantêm o princípio da separação entre a Igreja e o Estado, porém, no período que ora estudamos 1964 a 1986, tal princípio era apenas um argumento doutrinário e retórico, pois, na prática cotidiana, densas articulações e barganhas políticas permearam a trajetória dos irmãos protestantes no Brasil e na Bahia, foco específico da nossa análise.

\footnotetext{
${ }^{1}$ Doutora em História, Professora Titular Plena da Universidade Estadual de Feira de Santana (UEFS), Coordenadora do Mestrado em História da UEFS.

${ }^{2}$ Denominação é um tipo de entidade protestante que reúne o conjunto das congregações que seguem as mesmas doutrinas e práticas, não tem a visibilidade da igreja, nem o absenteísmo das seitas.
} 
Os protestantes produziram discursos e representaçôes peculiares e instigantes sobre os governos militares, os quais estavam pautados por doutrinas internas ao seu ideário religioso, porém guardavam estreitas vinculações com as práticas políticas da sociedade circundante. Nessa perspectiva, o conceito de campo religioso e de capital simbólico de Pierre Bourdieu é um instrumento teórico relevante para entendermos tais vinculações entre a religião e a política:

A estrutura das relações entre o campo religioso e o campo do poder comanda, em cada conjuntura, a configuração da estrutura das relaçôes constitutivas do campo religioso que cumpre uma função externa de legitimação da ordem estabelecida na medida em que a manutenção da ordem simbólica contribui diretamente para a manutenção da ordem política. (BOURDIEU, 1974, p. 69)

Entendemos a religião como uma forma de expressão da cultura, a qual mantém estreitos vínculos com os demais elementos constitutivos de um sistema cultural. As contribuições teóricas da História Cultural, numa interface com a História das Religiōes, são fundamentais à problemática que ora analisamos.

O conceito de representação, formulado na perspectiva da História Cultural, é relevante para se entender e explicitar as relaçôes políticas e os conflitos ocorridos no campo religioso brasileiro no período em foco. Admitimos representação como a compreensão que os homens buscam do funcionamento de uma dada sociedade ou as operações intelectuais que lhes permitem apreender o mundo (CHARTIER, 2002, p.23). Observa-se, historicamente, que a visão de mundo, as representações coletivas que se elaboram em certos grupos têm, no fenômeno religioso, um elemento central preponderante em determinados momentos.

As representações e as práticas políticas elaboradas pelos protestantes estavam essencialmente vinculadas à forma de existência desse grupo religioso na sociedade brasileira e baiana, no contexto conjuntural das décadas de 1960 a 1980, plena de agitação e movimentos sociopolíticos, os quais marcaram, também, os arraiais protestantes, inclusive os batistas. Nas sociedades em geral, as relações entre a religião e a política estão tão imbricadas que alguns estudiosos afirmam que no seio das instituições sociais e simbólicas "se articulam ao mesmo tempo o político e o religioso" (HERVIEUR-LÈGER, 2005, p. 190). 


\section{Preces explícitas e críticas veladas}

Além do principio doutrinário de absoluta separação entre as instâncias eclesiásticas e as instâncias governamentais, os batistas no Brasil desenvolveram um pensamento e uma prática política de sistemática submissão às autoridades. Faziam uma leitura literal do texto bíblico, de origem paulina, que toda autoridade vem de Deus e seus servos devem obedecê-la. Apenas em matéria de fé, "quando importava mais obedecer a Deus do que aos homens", os irmãos batistas esboçavam alguma crítica ou resistência.

No Jornal Batista, noticioso nacional da Denominação, em artigos e editoriais recorrentes, destacava o espírito ordeiro dos batistas, os quais só criticavam as autoridades constituídas se elas atentassem contra a liberdade religiosa, favorecendo a Igreja Católica, ou se as eleições ocorressem no dia de domingo, o dia do Senhor, consagrado aos exercícios devocionais nos templos. Pecado que deveria ser evitado pelos fiéis.

Essa prática de submissão e respeito às autoridades, sem críticas ou contestações, perpassou a República Velha e o Estado Novo sem alterações substanciais. No entanto, a partir da agitação política e social que caracterizou o final da década de 1950 e o início dos anos 1960, os batistas viram-se incomodados com as reivindicações e os espaços políticos que os movimentos sociais organizados e os partidos de orientação marxista passaram a disputar no cenário nacional.

O tumultuado governo de João Goulart, que começou resistindo ao veto dos ministros militares, os quais consideravam a posse do vice-presidente, como mandatário presidencial no lugar de Jânio Quadros, que havia renunciado em agosto de 1961, "um perigo para a ordem social do Brasil", também foi objeto das preocupações e das orações dos irmãos protestantes.

O governo de Jango, que passou à História do Brasil como um período de reformas nacionalistas, viveu tensões e conflitos políticos acentuados por uma grave crise social que punha em risco o precário equilíbrio entre as diversas classes sociais. Segundo um estudioso do período:

A economia brasileira entrara em um longo ciclo depressivo, desde 1962, agravado por uma inflação crescente, que paralisava as obras consideradas básicas pelo governo, visando a uma melhor distribuição de renda, e causava forte pressão sobre os salários, originando um clima de enfretamento entre patrôes e empregados, que vinha se somar à crise política mais geral. (SILVA, Francisco, 1990, p. 316) 
Diante das turbulências e do acentuado perfil popular e nacionalista do governo janguista, o princípio da submissão às autoridades constituídas sofreu arranhões: os batistas passaram a preocupar-se com os destinos do País e construíram veladas críticas, ao mesmo tempo em que acionavam os mecanismos religiosos que consideravam eficazes para solucionar os problemas brasileiros: oração e leitura da Bíblia. A liderança batista reconhecia "quão duras têm sido as dificuldades administrativas e como é grave a problemática nacional”3. Tal reconhecimento e solidariedade foram declarados de viva voz, por um grupo de batistas, dentre outros evangélicos, os quais foram recebidos pelo Presidente João Goulart em audiência especial.

A lealdade e a submissão ao governo foram destacadas, porém uma outra interpretação do fato pode ser acrescentada: mais uma vez, na iminência de um desfecho trágico para a crise, os batistas queriam garantias da continuidade da liberdade religiosa, do respeito ao princípio constitucional e de que não seriam molestados. Ao mesmo tempo, era um voto de confiança e solidariedade, embora efêmero e pontual, como veremos a seguir. O Pastor Eber Vasconcelos, da Igreja Memorial Batista de Brasília, foi o porta-voz do grupo evangélico que visitou Jango e explicitou sua opinião nos seguintes termos:

[...] Aqui estão os pastores evangélicos do Distrito Federal, representando cerca de 60 igrejas numa sincera e desinteressada homenagem a Vossa Excelência. Aqui estamos para trazer nossa palavra de solidariedade. Não viemos pedir - pois o povo evangélico não pede - mas para dar nosso apoio moral e nossa assistência espiritual ao governo de Vossa Excelência. A Bíblia nos ensina o respeito às autoridades legalmente constituídas e nos concita a colaboração com aqueles que trabalham com o bem-estar coletivo... tem Vossa Excelência nosso apreço e simpatia. ${ }^{4}$

No caso específico da conjuntura crítica do governo Jango, o princípio da submissão e da lealdade se configurava especialmente no plano da retórica, críticas veladas e cautelosas passaram a figurar nos periódicos batistas. Com o agravamento da crise, no último trimestre do ano de 1963, a comunidade eclesiástica temia possíveis mudanças políticas:

\footnotetext{
3 "Evangélicos visitam presidente da República”. O Jornal Batista, p. 2, 25 maio 1963.

${ }^{4}$ Ibidem.
} 
[...] o discurso do Jornal Batista (sic) passou a discorrer sobre o comunismo, a tratar, sutilmente, o governo de forma mais crítica como na reportagem que noticiava uma palestra em uma Faculdade Batista sob o capcioso título: "Devemos temer o comunismo, mas, devemos temer muito mais, uma democracia em podridão"s.

\section{Os guardiōes da democracia ameaçada}

A crise social e política do governo João Goulart foi adensada por vários movimentos contestatórios, inclusive, motins dentro das forças armadas, a exemplo do motim de suboficiais da Aeronáutica e da Marinha que eclodira em Brasília, no final de 1963, exigindo direito de voto e melhores condições na tropa. Com firmeza e dificuldade, o governo tentou contornar a situação "através da decretação do Estado do Sítio, esvaziada pelos ministros militares, deixando a nu a falta de apoio ao presidente” (SILVA, Francisco, 1990, p. 321). O golpe, tramado desde 1961 pelos militares, teve um desfecho rápido e com o apoio de políticos civis como: o Governador de Minas Gerais, Magalhães Pinto (UDN); Ademar de Barros, Governador de São Paulo (PSP); Carlos Lacerda, Governador da Guanabara (UDN). Tentando evitar "um banho de sangue", o Presidente Goulart não reagiu, e seu cargo foi declarado vago pelo Congresso Nacional. Era março de 1964, o início de um longo regime militar discricionário e repressor das liberdades democráticas, o qual achacou a nação brasileira, por duas décadas.

As representações construídas, oficialmente, pelos batistas eram assaz peculiares. Na concepção dos irmãos da Convenção Batista Brasileira, o golpe militar de 1964 era, contraditoriamente, uma intervenção política em defesa da democracia, e da nação. Um beneficio ao País que vivia ameaçado em sua ordem democrática, e o ex-presidente deposto só merecia críticas, a solidariedade que havia sido jurada um ano atrás em visita especial a João Goulart foi completamente esquecida. De imediato, os líderes batistas legitimavam o golpe e o regime militar. Apenas doze dias após a eclosão da quartelada, publicavam nas páginas do Jornal Batista:

Os acontecimentos militares de 31 de março e $1^{\circ}$ de abril que culminaram com o afastamento do Presidente da República vieram, inegavelmente, desafogar a nação $[. .$.

${ }^{5}$ O Jornal Batista, 26 out. 1963. 
O presidente que vinha fazendo um jogo extremamente perigoso foi afastado. A democracia já não está mais ameaçada. A vontade do povo foi entendida e respeitada... o povo brasileiro por sua índole, pela sua formação, repele os regimes totalitários e muito particularmente o regime comunista. ${ }^{6}$

A pseudo omissão dos batistas frente às questões políticas do País se desvelou, para mostrar uma face ideológica e conservadora, aparentemente contraditória ao condenar o totalitarismo comunista, mas, ao mesmo tempo, legitimar o golpe militar, como se o mesmo não fosse um golpe de força que instalaria um regime totalitário, tanto quanto o comunismo que rejeitavam.

No processo de legitimação do golpe civil-militar de 1964 pelos líderes batistas, ressalta o conservadorismo político da Denominação Batista, o qual deve ser entendido com base em alguns fatores determinantes: ao longo de sua trajetória nos EUA e particularmente no Brasil, decorrentes da correlação de forças no próprio campo religioso brasileiro, os batistas desenvolveram uma perspectiva particular de democracia, que se confundia com a garantia de liberdade religiosa. Se apenas o direito de culto fosse preservado, estavam democraticamente contemplados. No imaginário batista, a democracia era o modelo eclesiológico.

O teólogo batista A. B. Langston escreveu um opúsculo editado pela Casa Publicadora Batista, em 1917, intitulado A verdadeira democracia, a qual, segundo o autor, acontecia plenamente entre os batistas ${ }^{7}$ que, por ela, deveriam pugnar, pois o Evangelho necessita de um ambiente democrático para florescer. O livro de Langston era estudado nos seminários batistas e suas ideias largamente difundidas nos jornais e revistas que eram estudados na Escola Bíblica Dominical das comunidades eclesiásticas. Os EUA, mais uma vez, eram o exemplo concreto de governo democrático.

Outro fator que exerceu um papel fundamental nesse processo de legitimação do golpe de 1964 foi a oposição ao comunismo. O medo e o pavor do comunismo faziam parte do imaginário batista, aprendido com os irmãos norte-americanos desde o início do século XX com o advento da Revolução Russa (SILVA, Elizete, 1998, p. 139). Os batistas condenaram o regime russo resgatando representaçôes muito caras do ideário batista e protestante em ge-

\footnotetext{
6 "Responsabilidade dos crentes nesta hora". Jornal Batista, p. 3, 12 abr. 1964.

${ }^{7}$ ALMEIDA, 2008, p. 18.
} 
ral: esconjuravam o comunismo como algo diabólico e convocavam o Senhor dos Exércitos para destruí-lo, pois o mesmo era parte do reino do Diabo.

Do ponto de vista da liderança batista, o comunismo precisava ser combatido pelo seu ateísmo e negação da religião. Dois meses antes da eclosão do golpe de 1964, diante do avanço dos partidos de esquerda e dos movimentos sociais, num trocadilho capcioso, os batistas desqualificavam as ideias comunistas: "o comunismo e não a religião é que é o ópio do povo. Por isso andam muito narcotizados e já não podem pensar por suas próprias cabeças à luz do Evangelho de Cristo"s.

O ateísmo era a principal crítica que se fazia ao comunismo. "Observase, portanto, que o discurso anticomunista defendido no meio batista transcendia o terreno político onde comumente se faz a crítica a essa ideologia para o campo religioso" (ALMEIDA, 2008, p. 32). A imprensa batista, no período, reverberou insistentemente contra o comunismo, o "perigo vermelho que rondava o País e queria tirar Deus dos coraçōes":

Nikita Krushev, Titov, Mao Tse-tung, Fidel Castro. São homens que derramam ódio pelo mundo e o seu principal e obstinado objetivo é desarraigar a ideia de Deus do coração humano [...] Odeiam, espalham a guerra, semeiam a destruição, tiram a vida do seu semelhante e se dizem promotores e mantenedores da paz. ${ }^{9}$

Um outro aspecto a ser considerado no processo de legitimação do golpe de 1964 no bojo do "perigo vermelho," foi a guerra fria mantida pelos EUA e os países do bloco comunista. Os irmãos batistas brasileiros tinham profundos laços espirituais e ideológicos com os "irmãos da Outra América”. Os Estados Unidos, ferrenho opositor do socialismo e mentor de vários golpes e governos militares na América Latina, também eram o "berço do Evangelho", a nação evangélica que mandava missionários filantropos e bem intencionados para o território brasileiro.

Os EUA eram a "utopia implícita do protestantismo brasileiro", como asseverou o presbiteriano Rubem Alves (1979, p. 239). Os americanos abominavam o comunismo e, na ótica dos batistas e dos protestantes em geral, os EUA chegaram ao progresso material e cultural em decorrência dos princípios evangélicos e democráticos.

8 "O comunismo é o ópio do povo". O Jornal Batista, p. 8, 25 jan. 1964.

9 "Perigo vermelho". O Jornal Batista, p. 6, 3 maio 1964. 
Prevaleceu a máxima: o que não é bom para os Estados Unidos não é bom para o Brasil, num completo alinhamento ideológico que passava pelos sermões e púlpitos dos missionários norte-americanos batistas. $\mathrm{O}$ missionário batista Burley Cader, que missionava na Bahia no período, era incisivo nos seus sermóes: "Deus usou os militares como instrumentos para salvar o Brasil do comunismo", dizia em seu português arrevesado com forte sotaque americano-sulista.

Em 1964, o Jornal Batista saiu em defesa do golpe de 31 de março e lamentou o fato de muitos jovens terem sido enganados. "Até em nossas igrejas se produziu a infiltração. Existia a louca ideia de que era possível embarcar-se no mesmo barco dos comunistas para construir os mesmos ideais" ${ }^{10}$. Esse trecho era parte do editorial do jornal, escrito pelo Pastor José Reis Pereira, publicado em negrito, certamente para chamar a atenção dos leitores e admoestá-los para não cair no "engodo dos vermelhos"; ao mesmo tempo, era uma demonstração de apoio explícito ao governo militar, instalado pela força das armas. Nesse momento, os princípios democráticos batistas foram completamente esquecidos.

Não podemos olvidar que o programa Aliança para o Progresso, lançado pelo Governo Kennedy, em 1961, e que cobriu toda a América Latina, atingiu, também, as comunidades batistas do Brasil, as quais recebiam roupas e alimentos dos beneméritos irmãos norte-americanos. Esse programa de ajuda, na verdade, era uma face da guerra fria, uma tentativa de manter a liderança dos EUA no continente, contra as possibilidades de propagação da Revolução Cubana.

Entre os evangélicos baianos, os alimentos para a paz tiveram uma grande aceitação, especialmente nas comunidades de maioria de baixa renda. Em julho de 1962, a Primeira Igreja Batista de Feira de Santana "votou unanimemente entrar na campanha de distribuição de alimentos para a paz" ${ }^{11}$, angariados por intermédio da Convenção Batista Brasileira. É importante salientar que os membros da comunidade percebiam a importância da assistência social, a ponto de criar uma comissão específica para esse trabalho, que se constituía das pessoas mais destacadas na hierarquia do grupo. Os irmãos norteamericanos eram reconhecidos e vistos como bênçãos divinas, modelos para os brasileiros.

\footnotetext{
${ }^{10}$ O Jornal Batista, p. 3, 12 abr. 1964.

${ }^{11}$ Livro de Atas da Primeira Igreja Batista de Feira de Santana.
} 


\section{Da simpatia à colaboração política}

O espírito proselitista tão característico da Denominação Batista, diante da crise que o Brasil vivia às vésperas do golpe civil-militar de 1964 foi o motor de uma grande campanha de evangelização nacional, a qual pretendia ser a solução para os graves problemas do País. Em janeiro de 1964, em reuniōes na Convenção Batista Brasileira, no Rio de Janeiro a liderança denominacional assim se expressou:

Considerando a gravidade do atual momento brasileiro, que está a exigir uma participação mais efetiva dos batistas, eis que eles têm uma mensagem decisiva para a atual conjuntura; considerando que tal participação se faz urgente, tamanha é a vertiginosidade com que os acontecimentos se sucedem fazendo prever profundas mudanças no país, considerando que é missão precípua dos crentes evangelizar, para o que contam com o apoio irrestrito de Cristo; Propomos que a CBB lance, nos primórdios de 1965, uma Campanha Nacional de Evangelização [...] $]^{12}$

A proposta da realização da campanha evangelística foi aceita pelos convencionais, organizada e propagada ao longo do ano de 1964, como uma revolução espiritual que iria ao encontro do povo brasileiro. Os órgãos informativos da Denominação foram eficazes veículos da propaganda evangelística, uma verdadeira panacéia para a enfermidade do país, garantia o Presidente da Convenção Batista Brasileira, Pastor Rubens Lopes:

Vai acontecer no Brasil em 1965, outra revolução. Outra, mas esta branca, pacífica, sem sangue. Será uma revolução espiritual, de dimensões nunca vistas na História deste país. Será uma revolução em profundidade. Será uma revolução de consciências. Será uma revolução feita não a partir da pólvora, senão a poder do fermento. ${ }^{13}$

No discurso pastoral, a pólvora era uma representação das forças militares a serviço dos governantes, e o "poder do fermento" referia-se ao poder e à eficácia da "Palavra de Deus", era uma representação bíblica que indicava o

\footnotetext{
${ }^{12}$ Atas e Relatórios da Convenção Batista Brasileira, janeiro de 1964, p. 166.

13 “Não desminta nosso presidente". O Jornal Batista, 20 set. 1964.
} 
poder do Evangelho para solucionar os problemas políticos. Uma clara referência à parábola de Jesus: "O reino dos céus é semelhante ao fermento que uma mulher tomou e escondeu em três medidas de farinha, até ficar tudo levedado" 14 .

O mote da campanha, Cristo a Única Esperança, claramente se reportava ao contexto sociopolítico do Brasil. O hino oficial, divulgado em todas as vias de comunicação da Denominação Batista, era uma conclamação aos fiéis para as lides proselitistas, ao mesmo tempo uma profissão de fé no poder regenerador do Evangelho e as bênçãos que o mesmo traria para o País. Eis algumas estrofes, cantadas em vibrante ritmo de marcha:

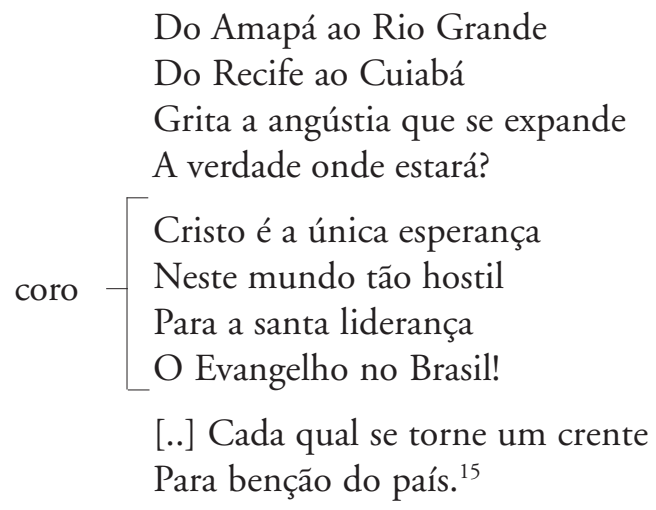

A campanha nacional de evangelização foi uma das respostas dos batistas à conjuntura nacional durante o golpe de 1964. A outra atitude, complementar às súplicas e campanhas proselitistas, foi uma densa articulação com os governos militares. A pseudo omissão política dos irmãos desvelou-se publicamente: não só legitimavam o regime militar, mas passaram a colaborar com as instâncias governamentais e a pleitear, num jogo de intensas barganhas, cargos e postos políticos em nível federal, estadual e municipal.

Este posicionamento da Denominação Batista também ocorreu entre os presbiterianos (Cf. ARAÚJO, 1985). Leonildo Campos estudou as relações dos presbiterianos independentes com os governos militares, destacou a colaboração de vários pastores como agentes da Polícia Federal e de outros órgãos repressores, bem como o serviço de delação prestado por vários irmãos às auto-

\footnotetext{
${ }^{14}$ Bíblia Sagrada, Mateus 13 v. 33.

${ }^{15}$ Convenção Batista Brasileira. 57a Assembléia. 1975, p. 13.
} 
ridades militares, acusando seus próprios irmãos de subversivos (CAMPOS, 2002, p. 122).

Conforme as fontes, a cooperação dos protestantes com os governos militares se concretizou em vários estados da federação. Neste artigo, destacamos o Estado da Bahia, pela sua representatividade numérica e simbólica no interior da Denominação Batista Brasileira e da Igreja Presbiteriana, haja vista o seu papel de celeiro de grandes lideranças.

A Convenção Batista Baiana, no período estudado, congregava dezenas de comunidades, dentre elas, a Igreja Batista Sião, fundada em 1936 e dirigida naquele momento pelo pastor e militar da reserva, Reverendo Valdívio de Oliveira Coelho. Tratava-se de um grupo de classe média ascendente, formado por várias categorias, dentre elas, profissionais liberais, médicos, estudantes universitários e militares em busca de visibilidade e participação na sociedade circundante. Sião era considerada a comunidade batista baiana mais prestigiada no período. Esse status advinha da sua composição social e das relações políticas desenvolvidas pela sua liderança, a qual contava com irmãos militares e a carismática presença da Dra. Alzira Coelho Brito, irmã sanguínea do Pastor Valdívio Coelho e casada com o deputado federal pela Arena Raimundo Brito, descendente de tradicional família baiana.

O advogado e professor da Universidade Federal da Bahia (UFBA), Raimundo Brito, era um político profissional, que começou à carreira parlamentar em 1934, na Assembleia Legislativa da Bahia, vinculado a UDN e ao interventor da Bahia, Juracy, Magalhães. Reeleito em várias legislaturas, Brito, na ocasião do golpe civil militar, pertencia ao Partido Republicano, mas logo de imediato perfilou-se na ARENA. Com uma folha de serviços prestados aos evangélicos, após a instalação do governo militar em 1964, transformou-se no grande articulador e mediador entre os batistas e as autoridades militares que governavam o País. Em 1967, foi considerado pelo jornal O Estado de São Paulo o melhor deputado da Câmara Federal. (BRITO, 1989, p. 96)

Em 1967, na vigência da Ditadura Militar, o Pastor Ebenézer Cavalcanti, líder batista, que pastoreava a Igreja Batista 2 de Julho, em Salvador, definiu a atuação de Raimundo Brito em "defesa dos evangélicos", nos seguintes termos:

Àquela época era ele uma espécie de porta-voz dos evangélicos nas relações públicas. Desde então não mudou, antes se intensificou e ampliou essa espécie sui generis de mandato implícito. Sempre advogou gratuitamente, in- 
teresses das igrejas e entidades evangélicas. Sua eleição se tem devido, em larga medida, ao eleitorado evangélico, a que serve. (BRITO, 1989, p. 96)

A barganha e o clientelismo político, que trocava votos por serviços assistencialistas, foram a tônica da intermediação que o Dr. Raimundo Brito desenvolveu entre os batistas e os militares. O Hospital Evangélico da Bahia, empreendimento capitaneado pelos batistas, especialmente pelo Pastor Valdívio Coelho e Dra Alzira Coelho Brito, foi a concretude da política do "é dando que se recebe" e do alinhamento da Denominação Batista ao regime militar. Segundo o Pastor Ebenézer Cavalcanti, referindo-se ao Deputado Federal Brito (1989, p. 96): "Sua vida ficará marcada na História pela fundação e funcionamento do Hospital Evangélico da Bahia, a que tem dado o melhor dos seus esforços".

Em 1966, numa demonstração de prestígio e colaboração, o Marechal Humberto de Alencar Castelo Branco, então presidente do País, doou um vasto terreno ao Hospital Evangélico da Bahia e, pessoalmente, lançou a pedra fundamental do referido hospital, no bairro de Ondina, em Salvador. Fontes iconográficas e impressas registraram o evento e a presença do marechal-presidente, recebido e ciceroneado entre os batistas pelo Pastor Valdívio Coelho, os diáconos Raimundo e José Coelho, Drª Alzira C. Brito e o Deputado Federal Raimundo Brito (1989, p. 97) ${ }^{16}$. Ainda nesse mesmo ano, o referido hospital foi considerado de utilidade pública, tendo na sua diretoria, como patrono, o “amigo dos evangélicos” Dr. Raimundo Brito.

Em 1971, o então Deputado Federal Antonio Carlos Magalhães foi indicado pelos militares para o Governo da Bahia. ACM, como viria a ser denominado no ambiente político, coordenou e consolidou sua liderança nas bases políticas da capital e do interior baiano. Ampliando seu raio de ação não esqueceu dos evangélicos, muito menos dos batistas. No mesmo ano, o Governador Magalhães convidou o deputado federal Raimundo Brito para ser Secretário da Justiça de seu governo (BRITO, 1989, p. 5, 16).

Nas memórias escritas por Dr ${ }^{\mathrm{a}}$ Alzira Brito, estão registradas, as principais realizações do Secretário Brito, destacando-se a construção de fóruns no interior da Bahia. Em meio ao autoritarismo dos militares e à truculência de Antônio Carlos Magalhães (ACM), dir-se-ia que o secretário da justiça não teria muitas possibilidades de atuação, mesmo se o quisesse. Ao que parece, a

\footnotetext{
${ }^{16}$ Documentos avulsos da Coordenadoria Ecumênica de Serviço (CESE).
} 
aplicação da justiça nesse período ficou circunscrita e delimitada aos espaços físicos, bem distante dos poróes e calabouços que a ditadura forjou no estado baiano e em todo território brasileiro.

As alianças entre o governo militar e os batistas baianos culminaram com a indicação do Dr. Clériston Andrade, advogado bem-sucedido, alto funcionário do Banco do Estado da Bahia e diácono batista conceituado, ao cargo de Prefeito da Cidade de Salvador, para o período de 1971 a 1975. O prestígio amealhado por Clériston Andrade nos espaços políticos baianos e brasilienses levou à sua indicação, por ACM, a candidato ao Governo do Estado da Bahia, em 1981. A eleição não se efetivou por causa de eventos patrocinados pelas "forças ocultas," divinas ou terrestres: "encontrava-se Cleriston Andrade em campanha eleitoral no interior do estado quando foi vitimado por um desastre aéreo a menos de um mês das eleições" (TAVARES, 2001, p. 491).

Os batistas baianos jamais haviam chegado tão próximos das entranhas do poder. Clériston Andrade era um atuante diácono da Igreja Batista Sião, posteriormente da Igreja Batista da Graça, tão envolvido nas lides denominações que a grande imprensa se reportava ao mesmo como "pastor batista". Tanto no Jornal Batista, quanto no Jornal Batista Bahiano, foram registrados recorrentes reportagens e eventos enaltecendo a atuação do "nosso irmão prefeito Dr. Clériston Andrade". Eis um extrato do relatório do missionário Burley Cader, o qual era secretário executivo da Convenção Batista Baiana no período:

Pela primeira vez na história da Bahia, onde o país e o trabalho Batistas nasceram temos um crente como prefeito. Isto é uma grande vitória. Dr. Clériston de (sic) Andrade tem testemunhado do poder do Evangelho pelo seu caráter cristão, pela sua maneira de viver corretamente, e imparcialidade nas suas decisões. Cada crente Baiano deve orar por este servo de Deus. (BURLEY, 1970)

A "maneira de viver", o "caráter cristão", nas palavras do missionário, eram requisitos para a realização da vocação política por parte do Dr. Clériston Andrade, desconsiderando as alianças e relações políticas, de caráter essencialmente clientelista, e as disputas político-partidárias, em um momento de maior endurecimento do regime militar no Brasil.

A indicação do Diácono Batista Clériston Andrade para administrar a cidade de Salvador, sede do Arcebispado Primaz da Igreja Católica Brasileira, constituía, para os irmãos batistas, uma grande conquista, de extrema relevân- 
cia para um grupo religioso que buscava visibilidade. Às vésperas do seu centenário, considerada a Denominação Evangélica que mais crescia no período, portanto, um denso eleitorado majoritariamente conservador configurava-se para os militares como um forte aliado. Aliados preferenciais, especialmente quando parte do clero católico baiano estava alinhado à Teologia da Libertação e fazendo coro contra os desmandos da ditadura militar.

Em 1964, os batistas se autoreconheciam como "uma força ponderável, que ainda não foi suficientemente explorada”, ${ }^{17}$ conforme o Pastor Rubens Lopes, na ocasião, presidente da Convenção Batista Brasileira. Uma década após, em pleno governo militar, as fontes denominacionais revelam que tal potencial, certamente numérico e qualitativo começava a ter visibilidade, inclusive entre as autoridades governamentais. Conforme o texto/relatório da Convenção Batista Brasileira, realizada em 1975:

No Brasil, nesta década o nome Batista se tornou sinônimo de evangelista e o povo batista ganhou reconhecimento e admiração do povo e governo do país. O impacto foi além das fronteiras e hoje os batistas brasileiros se assentam ao lado dos "vip" batistas do mundo, nos movimentos mundiais de evangelização. ${ }^{18}$

\section{Entre a submissão e a resistência}

As lideranças evangélicas estavam satisfeitas com os conchavos e alianças com o governo militar, bem como gratas a Deus pela benção do reconhecimento das autoridades, seguindo assim o seu tradicional princípio de obediência e submissão aos investidos de poder, mesmo que fosse pela força das armas e do arbítrio. No entanto, tal posição não foi unânime entre os irmãos protestantes. Um segmento minoritário fez severas críticas à ditadura militar, o que levaria alguns jovens a sofrerem represálias e prisões.

Tal qual ocorreu em outras denominações evangélicas, os pastores batistas não viam com bons olhos a politização da Juventude Batista Baiana, com uma razoável presença de estudantes secundaristas e universitárias, partícipes e coadjuvantes no movimento estudantil organizado, o qual reagiu à ditadura militar e tomou as ruas da capital baiana e das principais cidades do interior,

\footnotetext{
${ }^{17}$ Atas e Relatórios da Convenção Batista Brasileira, 1964. p. 166.

${ }^{18}$ Atas e Relatórios da Convenção Batista Brasileira, 1975. p. 173.
} 
em protesto contra os militares, o acordo Ministério da Educação - United States Agency for International Development (MEC-USAID) e o imperialismo norte-americano.

Agostinho Muniz, estudante de jornalismo, líder da Juventude Batista Baiana e membro da Igreja Batista 2 de Julho, se reportou ao alinhamento do seu Pastor Ebenézer Cavalcanti aos governos militares e como os opositores do regime foram perseguidos dentro da própria comunidade religiosa e excluídos por serem oposição:

1966 é um ano emblemático da liderança protestante e de juventude, porque aí passam a correr as eliminaçóes desse pessoal que não rezava pela cartilha da liderança oficial da Igreja e dos pastores, Ebenézer mesmo, foi o primeiro a comandar uma grande exclusão desses jovens [que] eram poucos, não eram muitos $[. . .]^{19}$

O alinhamento dos protestantes à ditadura militar também se configurou no ignominioso papel da delação dos próprios irmãos, ditos "cor-de-rosa", aos órgãos da repressão. A cor rosa certamente era uma alusão à ideia de que os jovens opositores da ditadura eram comunistas disfarçados, ou "vermelhos" atenuados que se passavam por evangélicos para propagar as ideias subversivas no meio eclesiástico. Eis o relato do ex-presidente da Juventude Batista Baiana:

Em 1966 isso ficou muito claro uma [...] um engendramento, uma coisa articulada entre a repressão da Ditadura dentro das igrejas e a liderança, os líderes da igreja começaram a reagir contra aquele pessoal, que dentro da própria igreja era chamado de muito "cor de rosa", alguns chamados de comunistas como foi o meu caso, que denunciado ao serviço de repressão ao comunismo, fui denunciado como sendo atuante comunista, como tendo ligações com o Partido Comunista fora da Igreja e que eu atuava na igreja como um braço do Partido [...] eu nunca fui comunista, nunca pertenci ao Partido, nunca me atraiu o materialismo histórico. ${ }^{20}$

\footnotetext{
${ }^{19}$ Entrevista à autora em 02 de março de 2007.

${ }^{20}$ Idem.
} 
A repressão eclesiástica não apenas se deu através da delação, nem sempre confirmada de cooperação com os comunistas. Também ocorria como uma espécie de autopunição ou desencargo de consciência frente aos rigores doutrinários e das práticas conservadoras dos batistas. Outros jovens protestantes aderiram ao PC, a exemplo de Norberto Bispo Santos Filho, membro da Igreja Batista Dois de Julho, em Salvador, dirigida com mão forte pelo Pastor Ebenézer Cavalcanti. O jovem estudante do Colégio Central, em Salvador, fez parte de um grupo de ativistas nos anos 60, não chegou a ser preso, pois faleceu antes da polícia vasculhar a sua residência e ameaçar os membros da família. Segundo relato de sua irmã, Profa. Ellen Melo, o mesmo "não agüentou a pressão e pediu o seu afastamento da igreja, antes que o eliminassem, a igreja não suportava política, nem subversivos"21.

Um outro aspecto a ser ressaltado foi a identificação de ecumenistas e comunistas. Tal confusão ideológico-eclesiástica serviu para justificar expurgos das comunidades e delações de irmãos vistos como ecumenistas aos órgãos repressivos do governo militar.

A partir da década de 1950, a Confederação Evangélica do Brasil, através do setor Igreja e Sociedade, liderado por um grupo progressista e ecumênico, promoveu reflexões e a discussão de uma intensa agenda sobre os problemas sociais brasileiros. As consultas cessaram após o golpe militar de 1964. Foram apenas quatro eventos que tiveram uma forte repercussão na comunidade protestante, tanto positivamente, ao ampliar o raio de ação dos progressistas, como negativamente, ao se observar a reação conservadora dos fundamentalistas. As conclusóes da Conferência do Nordeste, sob o título Cristo e o Processo Revolucionário Brasileiro, e das anteriores foram compiladas, em forma de livro, por Waldo Cesar e divulgadas nas instituições eclesiásticas e no Boletim da CEB, Brasil Evangélico, que atingia a todas as denominações filiadas. A Confederação Evangélica também promoveu encontros em nível da América Latina, para discussão das questões sociais.

As conferências do Setor Social também repercutiram entre os católicos, em meio a setores significativos como a JUC, que teve representação oficial na Conferência do Nordeste. O jornal católico Brasil Urgente, mais tarde censurado e fechado, dedicou as páginas do meio ao evento, reafirmando que o protestantismo brasileiro tinha duas grandes fases: antes e depois da Conferência do Nordeste.

O novo discurso engajado desse grupo evangélico ecumênico também repercutiu negativamente, e a reação conservadora foi imediata. Nas páginas do Jornal Brasil Presbiteriano, o debate entre os dois grupos fez-se de forma

\footnotetext{
${ }^{21}$ Entrevista à autora em 03 de março de 2007
} 
intensa. O espectro do "comunismo ateu" rondava os arraiais protestantes. A luta de representações entre os dois grupos continuou acirrada e tomou feições políticas, típicas daquele período de conturbação política e fermentação ideológica. Os protestantes traziam para a arena eclesiástica a polarização em que vivia a sociedade brasileira.

Em julho de 1964, no ambiente de "caça às bruxas" instaurado pelo governo militar, começou o expurgo de professores dos seminários presbiterianos e conflitos entre seminaristas e as autoridades da hierarquia presbiteral. Vários professores foram afastados do Seminário do Norte, a exemplo do Reverendo Áureo Bispo, dos Santos que se integraria ao Presbitério de Salvador, o Reverendo João Dias de Araújo, que pastoreou em Wagner e Feira de Santana no período, com sua teologia crítica, "taxado de esquerdista e pró-comunista". No Seminário do Sul, em Campinas, e no Seminário do Centenário, em Vitória, fundado em 1958, por Joaquim Beato e Richard Shaull, os professores progressistas foram expulsos, inclusive sem receberem os seus direitos trabalhistas. (SILVA, Elizete, 2007, p. 105-108)

A repressão externa ao grupo progressista também foi muito forte. Convém salientar que a movimentação da Comissão de Igreja e Sociedade da Confederação Evangélica do Brasil, desde os anos 1960, levantou a suspeita dos órgãos de repressão, afinal de contas os "crentes" deixavam de ser respeitosos e submissos às autoridades constituídas e passavam a questionar e a organizar-se para fazer política. Recordou um dos líderes da comissão:

A visita de um agente do Departamento de Ordem Política e Social (DOPS) e o interrogatório a que submeteu Waldo Cesar indicavam o quanto nosso trabalho ultrapassara os limites eclesiásticos e instigava as autoridades da chamada segurança nacional. (SHAULL, 2003, p. 180)

Alguns jovens presbiterianos se lançaram na luta partidária, como Paulo Wright, militante da Ação Popular (AP) desde 1963. Ele foi deputado estadual por Santa Catarina, cassado em maio de 1964, clandestino em Cuba e de volta à clandestinidade no Brasil; militaria na $\mathrm{AP}$ até o seu desaparecimento nos porôes da repressão militar. Em junho de 1964, asilado na embaixada do México, esse sociólogo mandou uma carta ao irmão de sangue, Reverendo Jaime Wright, reafirmando o seu compromisso: "escrevo estas coisas para que você saiba que não me arrependo de nada do que fiz e nem pretendo desistir da luta que iniciei em obediência ao chamado do nosso Senhor comum". (WRIGHT, 1993, p. 49) 
A trajetória do Reverendo Celso Dourado é um exemplo dessa prática militante, participou ativamente dos comitês de Direitos Humanos e Anistia que existiram na Bahia e manteve as portas da Igreja Presbiteriana Unida e do Colégio 2 de Julho sempre abertas aos movimentos sociais, inclusive abrigando militantes clandestinos, a exemplo de Paulo Wright e outros filiados da tendência política de esquerda Ação Popular (AP). Como um bom discípulo de Shaull se lançou na vida político-partidária, desde a década de 1960. Foi eleito deputado constituinte em 1986, com uma brilhante atuação parlamentar, tendo recebido nota 9,75 do Departamento Intersindical de Assessoria Parlamentar (DIAP). Votou favorável à Reforma Agrária e contra todas as propostas reacionárias do "centrão"22.

Com o golpe militar de 1964, a repressão se intensificou não só pelo alinhamento tradicional do protestantismo aos governos de plantão, mas, também, pelas relações e vínculos de alguns ilustres protestantes ao regime. João Dias Araújo (1985) sugeriu que a

Igreja Presbiteriana foi a mais envolvida e a mais comprometida com a revolução de 1964 por causa das ligaçóes dessa Igreja com a classe média e por causa do prestígio político que ela gozava nos meios políticos e militares.

Vários presbiterianos ocuparam cargos durante a ditadura militar. Nehemias Gueiros, presbiteriano de Pernambuco, "entrou para a história como redator do Ato Institucional $n^{\circ} 2$. No governo Médici, o ministro Eraldo Gueiros ocupou o cargo de governador de Pernambuco". (ARAÚJO, 1985)

Os desencontros e os conflitos entre progressistas e a hierarquia eclesiástica aconteceram em várias regiōes do País. Rubem Alves, na época pastor presbiteriano no interior de Minas Gerais, além de sofrer as acusações e punições do Supremo Concílio da Igreja Presbiteriana, foi denunciado como subversivo aos militares. Havia um dossiê com denúncias "dos próprios irmãos, inclusive da direção do Instituto Gammom, escola protestante [...]”. Quanto às acusaçôes do Concílio Presbiteral, "eram mais de quarenta, graves e virulentas não só do ponto de vista religioso quanto político" (ALVES, 1987, p. 31). Amedrontado pelos militares, Alves aceitou um convite da Igreja Presbiteriana dos EUA para fazer um doutorado no Seminário Teológico de Princeton, onde o seu mestre Richard Shaull era professor.

\footnotetext{
${ }^{22}$ Entrevista à autora em 14 de março de 2007.
} 
O proverbial anticatolicismo dos protestantes de origem missionária reacendeu frente ao envolvimento de setores da Igreja Católica com a resistência à ditadura. Nas páginas do Jornal Batista, o setor progressista católico foi identificado como terroristas que queriam desestabilizar o governo militar, isso em pleno 1969, no auge do processo de repressão aos portadores de ideias oposicionistas:

Um dos grandes assuntos do momento é essa da prisão de padres, frades e freiras suspeitos de maquinações com grupos terroristas. Quanto a dois desses eclesiásticos não há dúvida de que faziam causa comum com os terroristas, pois foram eles mesmos que forneceram os recursos para uma cilada em que o principal chefe desses profissionais da violência foi morto pela polícia... Assim, pois, a prisão de tantos eclesiásticos deve ter sido causada por motivos extremamente sérios ${ }^{23}$.

Referiam-se ao cerco e assassinato do militante comunista baiano Carlos Marighella, em 4 de novembro de 1969, e acusavam os padres dominicanos de proteger os terroristas e subversivos "inimigos do regime". Se os padres católicos eram inimigos do regime militar, os batistas e os demais protestantes ortodoxos, por seu turno, queriam ser vistos como ordeiros e obedientes ao sistema.

\section{Considerações finais}

Pudemos observar na análise do material pesquisado que a Denominação Batista e a Igreja Presbiteriana do Brasil desenvolveram práticas, discursos e representações muito peculiares sobre o regime militar instalado no País, em 1964, e que as afinidades eletivas entre o conservadorismo protestante e a ditadura militar produziram convergências ideológicas e cooperação efetiva das instâncias eclesiásticas com as autoridades e governos militares. Na Bahia, tal articulação política foi mediada por dois grandes políticos da época: o Governador Antonio Carlos Magalhães e o Deputado Federal Raimundo Brito.

$\mathrm{O}$ assistencialismo dos protestantes aliou-se ao clientelismo que grassava na política brasileira, propiciando, assim, barganhas, troca de favores e benesses, os quais transcendiam o individualismo e justificavam-se como caridade cris-

23 “A prisão dos padres”. O Jornal Batista, 7 dez. 1969. 
tã, feita para a glória de Deus. A eleição em 1966 de vários deputados evangélicos e a indicação de irmãos para cargos executivos, a exemplo do Dr. Clériston Andrade, como prefeito de Salvador na década de 1970, foram a culminância desse alinhamento político.

Essas são apenas algumas considerações, há muito que pesquisar e investigar sobre esse tema tão instigante, isto é, as relações entre a religião e a política na recente História do Brasil e os papéis que os evangélicos representaram nesse contexto do regime militar, não só como colaboradores, mas, também, como oposicionistas no parlamento, a exemplo do Reverendo Celso Dourado, e militantes dos Direitos Humanos e comitês de anistia, os quais representavam um segmento ecumênico com uma visão política progressista e disputavam palmo a palmo os espaços eclesiásticos.

\section{REFERÊNCIAS}

ALMEIDA, Luciane Silva de. A igreja anticomunista representaçôes dos batistas sobre o regime militar em Feira de Santana: relatório de iniciação científica. Feira de Santana: UEFS, 2008.

ALVES, Rubem. Protestantismo e repressão. São Paulo: Ática, 1979.

. Da esperança. Campinas: Papirus, 1987.

ARAÚJO, João Dias de. Inquisição sem fogueiras. Rio de Janeiro: ISER, 1985.

BOURDIEU, Pierre. A economia das trocas simbólicas. São Paulo: Perspectiva, 1974.

BRITO, Raymundo de Souza. Evocaçōes. Salvador: Presscolor, 1989. 163p. Faz uma biografia de Alzira Coelho Brito.

BURITY, J. Os protestantes e a revolução brasileira: a conferência do Nordeste (19611964). Dissertação (Mestrado em Ciência Política) - Universidade Federal de Pernambuco, Recife, 1989.

BURLEY, Cader. Relatório de viagem: muitas lutas muitos desafios. Convenção Batista Baiana, dez. 1970.

CAMPOS, Leonildo Silveira. Protestantes na primeira fase do Regime Militar brasileiro: atos e retórica da Igreja Presbiteriana Independente (1964-1969). Estudos de Religião, São Bernardo do Campo: UMESP, v. 16, n. 23, p. 83-140, jul./dez. 2002.

CAVALCANTI, Ebenézer. Os Batistas e o ecumenismo. Rio de Janeiro: Casa Publicadora Batista, 1970.

CESAR, Waldo A. Protestantismo e imperialismo na América Latina. Petrópolis, RJ: Vozes, 1969. 
CHARTIER, Roger. A história cultural entre práticas e representaçôes. Lisboa: Difel, 2002.

FRESTON, Paul. Evangélicos na política brasileira: história ambígua e desafio ético.

Curitiba: Encontrão, 1994.

HERVIEU-LÈGER, Daniele. La religion, hilo de memória. Barcelona. Herder, 2005.

LEONARD, Émile. O protestantismo brasileiro. São Paulo: ASTE, 1963.

LÖWY, Michael. O Catolicismo latino-americano Radicalizado. Estudos Avançados, São Paulo: USP, v. 3, n. 5, p. 50-59, jan./abr. 1989a.

. Marxismo e cristianismo na América Latina. Revista Lua Nova, n. 19,1989b.

SHAULL, Richard. Surpreendido pela graça: memórias de um Teólogo Estados Unidos, América Latina, Brasil. Rio de Janeiro: Record, 2003.

SILVA, Elizete da. Cidadãos de outra pátria: Anglicanos e Batistas na Bahia. Tese (Doutorado em História Social) - Faculdade de Filosofia, Letras e Ciências Humanas, Universidade de São Paulo, 1998.

. Protestantismo ecumênico e realidade brasileira: trabalho de Professos Pleno. Feira de Santana: UEFS, 2007.

SILVA, Francisco Carlos Teixeira da. Do Golpe Militar à redemocratização 1964/1984. In: LINHARES, Maria Yedda. História Geral do Brasil. Rio de Janeiro: Campus, 1990.

TAVARES, Luis Henrique Dias. História da Bahia. Salvador: EDUFBA; São Paulo: UNESP, 2001.

TEIXEIRA, Marli Geralda. Nós os Batistas: um estudo de história das mentalidades. Tese (Doutorado em História Social) - Faculdade de Filosofia, Letras e Ciências Humanas, Universidade de São Paulo, 1983.

TIEL, Gerhard. Ecumenismo na perspectiva do Reino de Deus: uma análise do movimento ecumênico de base. São Leopoldo: Sinodal/CEBI, 1998.

WEBER, Max. A ética protestante e o espírito do capitalismo. São Paulo: Pioneira, 1967.

WEBER, Max. Economia e sociedade: fundamentos da sociologia compreensiva. Brasília: UNB, 1991.

WRIGHT, Delora Jan. O Coronel tem um segredo: Paulo Wright não está em Cuba. Petrópolis, RJ: Vozes, 1993. 



\section{Uma "revolução" contra o} comuno-peleguismo:

\section{o golpe de 1964 e o sindicalismo petroleiro}

Alex de Souza Ivo ${ }^{2}$

Havia algo de diferente naquela manhã em Salvador. O centro da cidade estava em alvoroço. Tropas saídas do Quartel da Mouraria marchavam pelas suas principais ruas. Autoridades confusas tentavam em vão falar com o governador Lomanto Júnior, no Palácio da Aclamação. Só quem tinha acesso a ele, eram os militares. Notícias confusas davam conta que tropas saídas de Minas Gerais mobilizavam-se contra João Goulart e ninguém sabia ao certo do seu paradeiro. O clima de tensão tomava conta de diversos setores do movimento social e se fez sentir também entre os dirigentes do sindicalismo petroleiro.

Mário Lima, presidente do Sindipetro/Refino e Deputado Federal pela legenda do PSB, havia saído logo cedo de casa em direção ao aeroporto. Precisava ir até a capital da república, pois a Câmara Federal havia convocado os parlamentes para uma sessão de emergência. Além disso, as notícias que che-

\footnotetext{
${ }^{1}$ Dedico este artigo à memória de Mário Soares Lima, mais destacada liderança sindical petroleira na década de 1960 e um dos principais atingidos pela violenta ação dos golpistas de 1964, falecido em Salvador a 10 de julho de 2009.

${ }^{2}$ Mestre em História pela Universidade Federal da Bahia. Professor do Instituto Federal de Educação, Ciência e Tecnologia da Bahia (IFBAHIA), Campus Vitória da Conquista.
} 
gavam à capital baiana não eram das melhores. Apesar de seu esforço, não conseguiu embarcar. Os vôos estavam suspensos e a única coisa que se tinha era uma série de informações desencontradas. O sindicalista decidiu, então, voltar para o centro da cidade, em direção à sede de seu sindicato, de onde havia saído na noite anterior após a realização de uma assembleia.

Chegando lá, encontrou nas imediações da Praça da Piedade alguns colegas que logo o informaram da presença de homens do exército dentro da sede da agremiação. Boatos estranhos corriam e davam conta de pessoas feridas no local que, no ano anterior, quando da sua inauguração, havia sido visitado por Jango. Mário Lima tentou romper a barreira montada pelos militares, usando da autoridade que o cargo legislativo lhe conferia, mas logo foi impedido pelo comandante da tropa de cavalaria. Recebeu a informação de que somente Lomanto Júnior poderia autorizar sua entrada. Não titubeou, pegou um carro e se dirigiu até o Campo Grande, onde estava localizado o Palácio da Aclamação, sede do governo da Bahia.

O sindicalista teve uma nova e desagradável surpresa ao tentar falar com o governador. Lomanto, que no dia anterior havia reunido-se com lideranças sindicais do estado e garantido que apoiaria a permanência do presidente da república em seu cargo e que lutaria pela legalidade constitucional, não aparecia para lhe receber e a "central de boatos" continuava trabalhando a todo vapor. Ao conversar com secretários e assessores do governador, recebia respostas evasivas, que informavam da existência de uma interminável reunião que impedia o diálogo entre parlamentar e o governador. Um de seus interlocutores, entretanto, o Secretário de Segurança do Estado, garantiu ao preocupado Mário Lima que não havia motivo para pânico, pois não havia nada de mais dentro da sede do sindicato. Mesmo assim, o dirigente sindical insistiu, perguntando ao secretário se ele havia visto com os próprios olhos a situação e se o seu nome poderia ser usado como garantia aos colegas de trabalho, que estavam preocupados, pois suas mulheres e filhos costumavam freqüentar a sede do sindicato em busca de produtos alimentícios mais baratos, os quais eram comercializados pela Cooperativa de Consumo, organizada pelos sindicalistas e que lá funcionava. A resposta foi negativa. O secretário informou-lhe que não poderia oferecer-lhe garantia nenhuma e nem o governador poderia fazer isso, pois a polícia não obedecia às ordens de nenhum dos dois, mas do comandante da VI Região Militar.

Mesmo temendo a prisão, por saber que não era bem visto pelos militares, o nosso personagem continuou sua peregrinação em busca de uma informação consistente sobre a real situação da sede do sindicato por ele comandado. Atendendo à sugestão do Secretário de Segurança, dirigiu-se para a sede da 
VI Região Militar em Salvador, ainda no centro da cidade, no bairro da Mouraria. Procurou o comandante da unidade e foi atendido de forma grosseira pelos militares. Recebeu a acusação clássica do período: a de ser um comunista. Defendeu-se dizendo que nunca foi do Partido Comunista e mesmo se fosse não poderia ser tratado daquela forma, pois além de ser um parlamentar, estava lá reclamando contra uma injustiça. $\mathrm{O}$ militar saiu, deixando o dirigente sindical só na sala por alguns instantes. Seu instante de solidão foi logo interrompido pela entrada de 4 soldados armados que ordenaram que se levantasse e o conduziram até um carro que o deixou no Forte do Barbalho. Foi o primeiro preso político a ser levado para lá quando do golpe de 1964. Logo depois, outros chegaram para lhe fazer companhia na mesma triste sorte. Dirigentes sindicais e estudantis, jornalistas e políticos, como o prefeito de Feira de Santana Francisco Pinto, ocuparam as celas da instalação militar ${ }^{3}$.

Enquanto isso, o clima nas unidades da Petrobras também não era dos melhores. Elas foram transformadas em alvo da fúria das camadas mais conservadoras da sociedade baiana. A Refinaria de Mataripe era tida como um verdadeiro reduto de "sovietes", onde os "bolcheviques" usavam as armas da própria estatal para atentar contra a ordem e a moral. Por isso mesmo, a sanha da caça às bruxas iniciadas naquele mês de abril não tardaria a atingir aquelas bandas do Recôncavo. Os sindicalistas, é lógico, não se fizeram de rogados. Pararam as atividades da empresa já no dia primeiro de abril. No dia seguinte, após a notícia da prisão do Mário Lima, exigiam a permanência da ordem constitucional, através da restituição do presidente João Goulart ao seu posto e da soltura imediata do seu "mandatário máximo"

De pronto o exército ocupou a refinaria. Tinha início a série de interrogatórios, delações, perseguições e demissóes contra sindicalistas e operários. Ernesto Cláudio Drehmer, engenheiro de confiança dos sindicalistas, içado à condição de Superintendente quando da saída de Jairo Farias para a direção da estatal, enviou de imediato um telegrama ao General Olympio Sá Tavares. Nele, congratulava o novo presidente da estatal pela nomeação e colocava à disposição o cargo que ocupava, comprometendo-se em permanecer no posto até a nomeação do seu substituto ${ }^{5}$. As iniciativas de resistência não haviam surtido efeito e já no dia 04 de abril os militares tornavam-se donos da situa-

\footnotetext{
${ }^{3}$ Baseado no relato de prisão do próprio Mário Lima, concedido ao autor em novembro de 2006.

${ }^{4}$ Termo de declaração de greve, anexado ao processo movido pela justiça militar contra Mário Soares Lima. Documento cedido ao autor pelo processado.

${ }^{5}$ Telegrama de Ernesto Drehmer a Olympio Sá Tavares. CPDOC-FGV, Al pcg 1964.01.30, doc. 17.
} 
ção. As unidades, lentamente, voltavam a funcionar. A essa altura, o grupo de sindicalistas indesejados já estava fora de ação.

Mesmo para os operários menos envolvidos com as questôes sindicais aqueles dias foram marcantes. As cenas presenciadas por muitos deles, nas quais as sedes dos sindicatos eram invadidas, seus arquivos e jornais eram expostos como troféus, colegas eram presos e interrogados, não saíram de suas memórias. Muitos deles certamente sequer sabiam o que era o tal do comunismo, que tanto se falava à época. A única coisa que tinham certeza era da violência dos homens da VI Região, da perseguição contra seus colegas e da destruição do patrimônio coletivo que eram os seus sindicatos.

Através desses fatos, a sanha perseguidora que se iniciara em Minas no dia 31 de março chegava aos petroleiros baianos. O presidente João Goulart vivera um governo marcado pela crise. Esta se principiou no impasse relacionado à sua posse e se arrastou durante os quase dois anos e meio que o maior herdeiro do varguismo esteve no poder. O presidente, sem uma sólida base de sustentação no Congresso Nacional, cambaleou entre um mandato próximo ao centro e às demandas das esquerdas, que embora não possuíssem uma representatividade que garantisse tranqüilidade a Jango no Legislativo Federal, constituíam um campo político com importante poder de mobilização e de inserção na sociedade brasileira. Elas traziam consigo as demandas das reformas de base e pressionaram Goulart de diversas maneiras até que este anunciou sua implementação no famoso comício de 13 de março de 1964, na cidade do Rio de Janeiro.

Daí para o acirramento da crise foi um pequeno passo. Os dias seguintes daquele fatídico mês reservaram outras surpresas ao governante. Os segmentos mais conservadores da sociedade brasileira aprofundaram a sua mobilização e no final de março, após uma séria crise na hierarquia das forças armadas, líderes políticos dos principais estados da federação, importantes organizações patronais e comandantes do exército transformaram os rumores de conspiração numa realidade. Tropas saídas de Minas Gerais encaminharam-se para a capital federal e começaram a contar com o apoio e a adesão de outros destacamentos do exército. João Goulart, acuado, pouco podia fazer e viu rapidamente o seu governo ruir. Em pouco tempo seguiu o caminho do exílio, procurando refúgio no Uruguai.

Todas as tentativas para impedir o golpe foram débeis e infrutíferas, afinal não podia ser diferente, pois suas principais bases de sustentação naquele momento - trabalhadores, estudantes e camponeses - não tinham força, preparo e armamentos para bater de frente com tamanha manifestação dos milita- 
res. Até mesmo as forças do Rio Grande do Sul, estado fortemente influenciado por Goulart e Leonel Brizola, não eram páreo para o efetivo mobilizado pelos golpistas. Conquanto existissem, em diversas partes do país, iniciativas, muitas vezes isoladas, para tentar romper o cerco do golpe e garantir uma sobrevida à experiência democrática brasileira, nenhuma delas obteve êxito.

$\mathrm{Na}$ Bahia não foi diferente. Além das greves no porto e nas unidades da Petrobras, parte da militância que se concentrava na capital rumou para Feira de Santana. Elas buscavam apoio junto ao prefeito da cidade, o pessedista Francisco Pinto, que tomou providências para a resistência, mas viu seus esforços frustrados em virtude da rápida ação da repressão, que ocupou as principais cidades do interior e impediu qualquer manifestação (DIAS, 2001, p. 62). Ademais, as notícias que chegavam não eram animadoras. Rapidamente não haviam mais militantes dispostos a defender a permanência de Goulart no poder. Restava a eles, a preocupação em salvar a própria pele, mantendo-se longe da prisão.

Voltando ao caso específico dos petroleiros, algumas perguntas ficam no ar. Qual o caminho percorrido pelas agremiações da classe petroleira até se transformarem num dos segmentos mais importantes do sindicalismo baiano? O que levou os autoproclamados revolucionários de 1964 a empreenderem tamanha perseguição contra os sindicalistas do petróleo?

\section{Os petroleiros baianos e o movimento sindical pré-1964}

A história do sindicalismo petroleiro baiano começou a ser construída ainda na década de 50, mais precisamente em 1954, quando foi criada a Associação Profissional dos Trabalhadores da Indústria do Petróleo no Estado da Bahia, entidade que deu origem aos sindicatos dos trabalhadores da extração e do refino do petróleo ${ }^{6}$, fundados, respectivamente, em 1957 e 1959. Contudo, a atuação efetiva e destacada do sindicalismo petroleiro começou na década seguinte, através da greve que reivindicava equiparação salarial entre os trabalhadores que serviam na Bahia e em São Paulo, comandada pelo Sindipetro/Refino.

Após essa etapa, as atividades sindicais petroleiras ganharam grande repercussão. Ao passo em que obtinham conquistas importantes relacionadas ao

\footnotetext{
${ }^{6}$ Esses dois sindicatos, o Sindicato dos Trabalhadores da Indústria de Extração do Petróleo do Estado da Bahia (Sindipetro/Extração) e o Sindicato dos Trabalhadores da Indústria de Destilação e Refinação do Petróleo do Estado da Bahia (Sindipetro/Refino) existiram até o ano de 1996, quando se fundiram, dando origem ao Sindicato Unificado dos Petroleiros (SUP). Quatro anos depois houve uma nova fusão, quando os petroleiros uniram-se aos Químicos, dando origem ao Sindicato dos Trabalhadores do Ramo Químico e Petroleiro do Estado da Bahia, atual entidade de representação da categoria.
} 
chão da fábrica e avançavam em reivindicações salariais, os petroleiros ganhavam destaque dentro da empresa. Os dirigentes sindicais do petróleo articularam em seu discurso e em sua prática elementos políticos e uma profunda preocupação relacionada com questões imediatas e importantes do ambiente de trabalho. Exatamente por isso, em 1961, enquanto ganhavam espaço e legitimidade junto à categoria, foram capazes de garantir importante mobilização em defesa da posse de João Goulart, declarando-se, inclusive, em greve e em assembleia permanente até que o impasse fosse solucionado. A posse do novo presidente da república, consolidada em setembro daquele ano, não representou, contudo, o fim da crise política enfrentada pelo país. A situação do governante mantinha-se complicada. Jango procurou, então, negociar e tentou manter-se equilibrado entre os diferentes grupos políticos que participavam da política brasileira. Para isso, sem abrir mão do diálogo com as esquerdas, costurou uma aproximação com o Partido Social Democrático (PSD) (FERREIRA, 2003, p. 348).

As unidades da Petrobras, por sua vez, também foram protagonistas da crise política brasileira entre os anos de 1961 e 1962. Os problemas arrastavamse desde o governo anterior, quando Jânio Quadros, atendendo pressōes vindas de setores empresariais e da imprensa baiana, começou a tomar providências para efetivar a transferência da sede da estatal para Salvador (OLIVEIRA JR, 1996, p. 99-101). A sua renúncia, contudo, abortou a proposta, mas não acalmou as elites locais que continuavam de prontidão em busca de maiores retornos oriundos das atividades petrolíferas realizadas no estado. Empresários, políticos e imprensa argumentavam que a Bahia, apesar de ser a única produtora de petróleo da federação, era tratada de forma desigual pelo governo federal (IVO, 2008, p. 39-47). Nesse contexto, pressionaram para inserir baianos na direção da empresa, conseguindo, na presidência de Jânio, a nomeação de Josaphat Marinho para a presidência do Conselho Nacional do Petróleo (CNP) e de Geonísio Barroso para a direção da Petrobras. Antes disso, o economista Pinto de Aguiar havia ocupado o cargo de diretor de operações da estatal.

Em janeiro de 1962, porém, por decisão do Ministério de Minas e Energia, Barroso foi demitido da direção da empresa. O fato ocasionou um grande impasse, resultando em uma greve dos trabalhadores baianos, cessada somente com a nomeação do socialista Francisco Mangabeira para o comando da estatal. O nome do novo dirigente agradou os sindicalistas, que contaram com sua participação na I Convenção Nacional dos Trabalhadores da Indústria do Petróleo, realizada entre os dias 19 e 21 de Janeiro na própria Salvador. Nesta ocasião, o novo presidente afirmou seu compromisso com os dirigentes sindicais, pois além de se comprometer com a declaração de princípios aprovada no 
evento, disse que não mediria esforços para garantir a total equiparação salarial entre baianos e paulistas (IVO, 2008, p. 145-146).

A presença de Mangabeira frente à Petrobras representou uma aproximação efetiva entre os sindicalistas e o alto comando da empresa. Eles passaram a exercer um relevante papel no jogo de poder da Petrobras, interferindo na nomeação de diretores e nas diretrizes políticas da estatal do petróleo. Antes mesmo de assumir o cargo e de participar do conclave operário, o socialista não media esforços para angariar o apoio e consolidar a aproximação com os trabalhadores. Para tal, distribuiu nota à imprensa, na qual se comprometia em criar o cargo de Diretor Social, que deveria ser indicado pelos sindicatos, através de lista tríplice. $\mathrm{O}$ novo presidente visava com isso garantir que os trabalhadores, através de seus órgãos de classe, ficassem "em permanente entendimento com a direção da Petrobras” (MANGABEIRA, 1964, p. 182). A atitude do socialista condizia com a própria linha política do presidente Goulart, que tinha nos sindicatos de trabalhadores uma de suas mais importantes bases de sustentação. Essa prática, todavia, atraiu para o presidente da república diversos inimigos e o mesmo aconteceu com Francisco Mangabeira.

Quatro meses após a sua posse, estourava a maior crise de sua gestão. Diversas associações de engenheiros criticaram a condução empreendida por Mangabeira e o acusavam de desestabilizar a Petrobras. O presidente da empresa respondeu aproximando-se ainda mais dos sindicatos, que se tornaram a sua principal e talvez única base de sustentação. A partir daí, os petroleiros baianos começaram a ganhar imenso espaço nos seus locais de trabalho. Primeiro, vieram as modificações nos quadros de comando das unidades da estatal na Bahia. Depois, a instalação de comissões paritárias de disciplina e enquadramento. Esses avanços, sem precedentes nas relações de trabalho das empresas estatais, não foram bem vistos por alguns.

\section{O sindicalismo petroleiro e a radicalização política do início da década de 60}

Enquanto os sindicalistas ganhavam espaço em seu local de trabalho e com isso eram obrigados a lidar com questôes mais imediatas do cotidiano operário, o clima político do país pegava fogo. João Goulart se esforçava para retomar o modelo presidencialista, as reformas de base eram tidas pela esquerda como a solução para a crise social e econômica que o país enfrentava. Palavras de ordem ecoavam de diversos cantos do país e forças conservadoras articulavam-se para impedir o avanço das esquerdas. 
Nesse contexto, os dirigentes sindicais petroleiros resolveram disputar as eleições parlamentares de 1962. Sob a legenda do PSB e com o slogan de "Trabalhador vota em trabalhador autêntico", Mário Lima e Wilton Valença, presidentes do Sindipetro/Extração e Sindipetro/Refino, saíram candidatos aos cargos de Deputado Federal e Deputado Estadual, respectivamente. Os candidatos trouxeram para a eleição baiana de 1962 a plataforma das esquerdas, defendendo as reformas agrária, cambial, tributária, educacional, a regulamentação do direito de greve e pedindo a nacionalização das refinarias particulares de petróleo ${ }^{7}$. O resultado do pleito garantiu os dois sindicalistas como representantes no legislativo e demonstrou mais uma importante vitória dos petroleiros. A partir de então, os dois parlamentares viraram relevantes atores na defesa das pautas progressistas e conseguiram ampliar ainda mais a inserção dos sindicatos dos trabalhadores do petróleo no jogo político nacional.

Essas novidades trouxeram um aumento na vigilância da polícia política sobre os petroleiros. Em fevereiro de 1963, o Departamento Estadual de Segurança Pública da Bahia informava aos órgãos de repressão do Rio de Janeiro que o ato organizado pelo Sindipetro/Extração sob o slogan "tudo de petróleo para a Petrobras" tinha a intenção subversiva de defender a encampação da refinaria de Capuava, a libertação de membros das Ligas Camponesas presos sob a acusação de homicídios e incentivar a "invasão de propriedades agrícolas"8. Os representantes sindicais da indústria petroquímica em fase de instalação também foram vítimas da vigilância policial. Em comício realizado em setembro do mesmo ano, o militante comunista e delegado sindical Jair Pinto de Brito teve seu discurso acompanhado de perto pelos agentes da polícia, que fizeram questão de registrar o "teor violento" de sua fala, que exigia a nacionalização de Capuava e, caso esta não fosse feita, "o PC faria à força" .

Contudo, não era só a polícia que voltava seus olhos furiosos e preocupados para os petroleiros. $\mathrm{O}$ avanço das atividades sindicais e a adoção de uma plataforma política nitidamente de esquerda fez com que a imprensa local manifestasse preocupação com as novas atitudes dos sindicalistas. No final de 1962, A Tarde, o maior jornal baiano começou, através da matéria intitulada O soviete de Mataripe uma série de acusações de teor anticomunista contra os sindicalistas do petróleo (OLIVEIRA JR., 1996, p. 135).

\footnotetext{
7 "Porque somos candidatos". Sindipetro-Jornal, p. 4, n. 20, set. 1962, n. 20.

${ }^{8}$ Arquivo Público do Estado do Rio de Janeiro, Fundo: Polícias Políticas, Pasta: 5C, Folha: 1097.

${ }^{9}$ Arquivo Público do Estado do Rio de Janeiro, Fundo: Polícias Políticas, Pasta: 5, Folha: 36.
} 
O principal alvo de $A$ Tarde era o arquiteto Jairo Farias, superintendente de Mataripe. O dirigente era acusado de, após conseguir ocupar posição-chave na estatal, comandar um grupo de comunistas que usava o dinheiro da empresa para alargar a área de influência do PCB. Segundo o jornal, Jairo contava com o auxílio de Plínio J. B. de Aguiar para atingir seus objetivos. O jornalista, diretor do jornal Folha de Mataripe, era digno da desconfiança de A Tarde porque apesar de se declarar "ex-colaborador de suplementos literários da capital", usava uma linguagem muito popular em seus textos, ao se valer de termos como "nós trabalhadores", por exemplo ${ }^{10}$. Os argumentos apresentados pelo jornal colocavam o dirigente da empresa e os sindicalistas como membros de uma grande conspiração que paulatinamente transformava Mataripe em um reduto vermelho. Outras matérias com o mesmo teor surgiram nas páginas do mesmo órgão de imprensa nos dias seguintes.

Os sindicalistas não tardaram em enviar suas respostas aos ataques sofridos. Em nota, divulgada através do jornal Diário de Notícias, Mário Lima reafirmou a posição autônoma do Sindipetro/Refino e disse saber a quem interessava as "campanhas caluniosas" que visavam "tumultuar as administraçōes da Petrobras e enfraquecer o monopólio estatal". Por fim, o dirigente sindical advertiu aqueles que duvidavam "da capacidade de luta do petroleiro brasileiro", pois os mesmos não hesitariam "em ir até às [sic] últimas conseqüências em defesa do patrimônio nacional já constituído pela Petrobras"11. A direção de Mataripe procurou também responder aos ataques de $A$ Tarde. Jairo Farias fez publicar mais uma nota no mesmo dia e no mesmo jornal usado pelo dirigente sindical. $\mathrm{O}$ tom de seu texto foi, contudo, muito menos enfático. $\mathrm{O}$ superintendente de Mataripe buscava refutar as acusações, esquivando-se de polêmicas. Disse, portanto, que não tinha responsabilidade pelo Jornal de Mataripe e que havia mandado, inclusive, recolher os exemplares. Ademais, garantiu que "dirigentes, técnicos e operários" da estatal realizavam suas tarefas "absolutamente alheios a atividades partidárias". Mesmo assim, Jairo Farias fez questão de reafirmar sua preocupação com as bandeiras de esquerda, dizendo que não se afastaria sequer "um milímetro" da defesa do monopólio estatal do petróleo ${ }^{12}$.

\footnotetext{
10 "O Soviete de Mataripe". A Tarde, 30 nov. 1962.

11 "O Sindicato dos Trabalhadores da Indústria de Destilação e Refinação do Petróleo do Estado da Bahia, tendo em vista o editorial do jornal A Tarde de 30 de novembro próximo passado, torna público:". Diário de Notícias, 3 dez. 1962.

${ }^{12}$ Idem.
} 
Entretanto, os editores do conservador jornal baiano não foram os únicos a enxergar em Jairo Farias uma grande ameaça comunista. As autoridades policiais também trataram de investigar a vida do mandatário de Mataripe. Em relatório de junho de 1963, os agentes de polícia traçaram uma breve biografia do arquiteto, que foi identificado como "comunista desde os tempos de ginasiano" em Maceió, sua cidade natal. Definido pelos investigadores como "incompetente e desleal, ligado apenas aos comunistas", Jairo era acusado de comandar, sob a orientação de Wilton Valença, e com o auxílio de Mário Lima e Alencar Ferreira Minho um processo de "bolchevização" da Refinaria de Mataripe e das demais unidades da Petrobras na Bahia ${ }^{13}$. Como podemos ver, o crescente prestígio e a mobilização dos petroleiros baianos eram tidos pelos setores mais conservadores da sociedade como uma verdadeira ameaça que deveria ser combatida a qualquer custo.

Os ataques aos petroleiros não paravam por aí e eram feitos, também, por notórios políticos. Em julho de 1962, Mário Lima foi a público polemizar com o General Juracy Magalhães, governador da Bahia. Juracy, que dois anos antes tentara aproximar-se dos dirigentes sindicais petroleiros, manifestando insatisfação com a demissão arbitrária de membros eleitos da sua diretoria (IVO, 2008, p. 126-127; OLIVEIRA JR, 1996, p. 78). O dirigente do Sindipetro/Refino fez publicar as páginas do Sindipetro - Jornal um artigo no qual questionava as acusaçóes feitas pelo governador, que o acusava de agitador comunista por causa de sua participação em manifestações, bem como de ser o responsável pela ociosidade dos operários nas unidades da Petrobras na Bahia. Mário Lima vangloriou-se da aprovação de sua linha política pelos petroleiros, que haviam acabado de elegê-lo presidente do sindicato com mais de $90 \%$ dos votos, ressaltando que não precisava seguir o caminho do general e sair de seu estado para obter votos. Lembrou também a "obsessão anticomunista" do governador, sempre preocupado "em encontrar comunistas" mesmo nos lugares onde eles não existiam. O dirigente sindical alertou a Juracy que nacionalismo não poderia ser confundido com comunismo e pediu mais respeito para com os petroleiros, que num "trabalho duro, diário e infatigável" ergueram Mataripe, aquele "símbolo da emancipação econômica nacional" e eram àquela altura os seus maiores defensores. Mário reafirmou que os trabalhadores do petróleo não hesitariam em fazer greve quando entendessem que estas fossem "vitais aos direitos dos trabalhadores", e à sua obrigação moral com pátria. Por fim, despediu-se do governador com uma provocação, dispensando "as liçôes de quem, em matéria de nacionalismo" não era nenhum professor ${ }^{14}$.

\footnotetext{
${ }^{13}$ Arquivo Público do Estado do Rio de Janeiro, Fundo: Polícias Políticas, Pasta: 5, Folha: 33.

14 “Resposta respeitosa, porém enérgica, ao General Juracy Magalhães”. Sindipetro-Jornal, n. 19, p. 6, ago. 1962.
} 
A essa altura dos acontecimentos não havia mais nenhuma possibilidade de aproximação dos sindicalistas com uma plataforma política mais à direita. Os petroleiros eram importantes articuladores do Comando Geral dos Trabalhadores em terras baianas e mostravam trânsito desenvolto junto ao presidente Goulart e às diretorias da Petrobrás por ele nomeadas.

\section{De volta ao olho do furacão}

O comício da Central do Brasil foi recebido com grande entusiasmo pelos petroleiros. Ele foi visto como o marco definitivo das mudanças que levariam à completa emancipação econômica do Brasil. A nacionalização da Refinaria de Capuava, uma importante demanda política dos petroleiros, foi tida como a demonstração cabal do triunfo do monopólio estatal do petróleo. Para os sindicalistas, Jango havia demonstrado sua disposição em enfrentar aqueles que eram considerados os verdadeiros inimigos do país.

Contudo, as reações conservadoras às medidas presidenciais e à mobilização dos trabalhadores não tardaram a aparecer. $\mathrm{O}$ jornal $A$ Tarde começou uma forte campanha de ataque a Goulart e seus aliados. A folha conservadora dizia que qualquer brasileiro que possuísse "menor dose de patriotismo" ficaria mais reservado após o "incendiário comício do dia 13", menos os membros do CGT, que faziam questão de colocar "lenha e gasolina" na fogueira do país. A entidade era acusada de pressionar o Congresso para que este aprovasse "a toque de caixa, e como se fosse um agrupamento ilícito ou irresponsável" as propostas de reformas encaminhadas por Jango. A Tarde lembrava a ilegalidade de organizações como o CGT, definidas como representantes de "alguns setores do comunismo indígena", e comandadas "pelos mais notórios delegados de Moscou". Segundo os articulistas, a pressão do CGT fazia parte das conspirações "antidemocráticas" dos comunistas, que haviam tomado posse do poder político do país e tentavam com as reformas de base acabar com a democracia no Brasil ${ }^{15}$. Os fatos dos dias seguintes de abril levaram Goulart à derrota e junto com ele seus grandes aliados.

A ação repressiva foi rápida e eficiente. As esperanças dos sindicalistas foram esvaindo-se à medida que os seus principais líderes eram presos e relevantes personagens políticos fugiam ou aderiam ao golpe. As palavras de Lomanto Junior, conclamando os trabalhadores a retornarem ao trabalho, são exemplares. Após conseguir garantir sua manutenção no cargo, o governador

15 "Lenha na fogueira". A Tarde, p. 1, 18 mar. 1964. 
pediu aos operários baianos que confiassem nas autoridades e não fossem "escravos de uma minoria de agitadores". Em nome dos valores cristãos e agradecendo ao Cardeal da Silva, Lomanto considerou aquele momento especial para a consolidação do regime democrático no país, pois os agitadores não teriam mais espaço. O governador dedicou atenção especial aos operários da Petrobrás, lembrando-os do papel da empresa na libertação econômica nacional e que a partir de então os petroleiros assistiriam a um regime democrático verdadeiro. Com as imediatas mudanças no comando da empresa e a incapacidade de resistência, Wilton Valença e Osvaldo Marques assinaram nota conjunta em nome dos sindicatos da extração e do refino, conclamando os petroleiros a retomarem suas atividades no dia 04 de abril ${ }^{16}$.

Com a invasão da sede dos sindicatos e de outras agremiações de esquerda, seu patrimônio foi vilipendiado e serviu para uma das primeiras demonstraçôes públicas dos autoproclamados revolucionários de 1964. Livros, panfletos e os mais diversos materiais foram expostos em vias públicas como exemplo $\mathrm{da}$ ameaça comunista que o Brasil havia sido libertado pelos militares. O golpe conseguiu expurgar do cenário político personagens considerados indesejáveis. De acordo com Maria Lygia Quartin de Moraes, os sindicalistas foram suas vítimas preferidas e estiveram presentes na maioria dos cerca de 307 processos encaminhados à justiça militar (MORAES, 2004, p. 305). As unidades da Petrobras na Bahia passaram por uma profunda investigação, resultando num volumoso Inquérito Policial Militar que investigou as atividades sindicais em Mataripe e foi concluído com um total de 1580 páginas. Em 1964, quinhentos e vinte e seis funcionários da Petrobrás foram demitidos (OLIVEIRA JR, 1996, p. 195, 197) e na Bahia pelos menos trinta e seis demissões se deram por questôes políticas ${ }^{17}$. O golpe civil-militar de 1964 representou a vitória de um modelo político autoritário, cujas oposições teriam pouco espaço. Por isso mesmo, as mobilizações sindicais foram seriamente comprometidas, mas não podemos dizer que teve fim a disputa pelo controle sindical petroleira e nem mesmo que as mobilizações políticas do setor cessaram.

No Sindipetro/Refino, a disputa pelo espólio político do grupo sindical comandado por Mário Lima e Osvaldo Marques começou ainda em abril de 1964, dias depois do Ministério do Trabalho declarar intervenção em todos os sindicatos baianos. Os avanços conseguidos pelos sindicalistas foram consideráveis e mesmo seus opositores sabiam disso e não por acaso desejavam serem vistos pela base como

\footnotetext{
16 “Convocação dos Sindipetros". A Tarde, p. 3, 4 abr. 1964.

${ }^{17}$ Petrobrás. Boletim Informativo 07/64, 28/08/1964. Memorial do Sindicato dos Trabalhadores do Ramo Químico e Petroleiro da Bahia.
} 
os detentores de seu legado. Para isso, precisavam antes de tudo convencer os militares que tomaram o comando da refinaria de que eram confiáveis e mantiveram-se distantes das ideias comunistas. Verdi Plesch e Gildásio Lopes, dois dos três dirigentes sindicais afastados da diretoria do Sindipetro/Refino em janeiro de 1963 escreveram uma carta para os novos gestores de Mataripe ${ }^{18}$.

Nela, os trabalhadores procuraram identificar-se com o Golpe de 1964, apresentando-se como participantes da "Revolução do 31 de março", desde que ela era apenas uma conspiração. Exatamente por esse motivo, sentiram-se à vontade para se colocar à disposição dos militares para ajudar no trabalho de convencimentos dos trabalhadores. Os signatários, numa evidente demonstração de aceitação do regime, tentavam tirar proveito da circunstância, dizendo que a cabeça dos operários da Petrobrás continuava sendo contaminada pelas mentiras dos "elementos residuais do comuno-peleguismo", que espalhavam boatos de que as conquistas salariais e os benefícios assistenciais fornecidos pela empresa seriam suspensos. Além disso, os autores da carta contavam que os "pseudolíderes" espalhavam o boato de que o direito de livre associação seria negado aos petroleiros. A preocupação dos remetentes da aos missiva corrobora com a tese de que mesmo após o golpe, militantes ligados ao grupo de Osvaldo Marques e Mário Lima permaneciam com certa influência junto aos operários de Mataripe.

Verdi Plesch e Gildásio Lopes elencaram, então, uma série de sugestões para os militares a fim de garantir a colaboração operária e o fim dos boatos que tanto atrapalhavam o bom andamento dos trabalhos da Refinaria. A primeira delas dizia que para aumentar a produtividade da unidade era necessário criar um programa de "contra-propaganda" para coibir as mentiras que corriam na usina. Também era preciso impedir o retorno ao comando da estatal dos "homens estigmatizados por notória aversão aos trabalhadores", numa clara alusão aos engenheiros afastados em 1962 por Francisco Mangabeira. Depois disso, os militares deveriam convencer aos operários de que "a Revolução" aconteceu para "corrigir por inteiro as deformaçôes sindicais" e que ela garantiria "as conquistas salariais e assistenciais, especialmente o reajustamento dos salários, previsto nos termos do acordo firmado entre a empresa e os sindicatos de sua órbita". Por fim, pleitearam a "presença operária na administração da empresa através da assessoria sindical”" 19 .

\footnotetext{
${ }^{18}$ Sobre as circunstâncias do afastamento de Verdi Plesch, Luciano Campo e Gildásio Lopes ver: Oliveira Jr. (1996, p. 146-149). A tese do autor para a saída dos dirigentes é que estes tinham uma posição mais à direita que o grupo de Mário Lima, o que os levava a criticar os rumos do sindicato. Além disso, eles foram responsáveis pela publicação de matérias que criticavam a gestão de Jairo Farias frente à Refinaria.

${ }^{19}$ Documento sem título, encontrado em CPDOC-FGV AL p/cg 1964/01/30, DOC. 96.
} 
Em resumo, excluindo o primeiro item, que dizia respeito à defesa das medidas saneadoras do "comunismo", ou seja, a retirada de seus desafetos políticos da cena, o conjunto de sugestôes dos emissários da carta era bastante parecido com as principais conquistas do grupo de sindicalistas que os mesmos acusavam de terem feito tão mal aos petroleiros e à empresa. Apesar das divergências políticas, Verdi Plesch e Gildásio Lopes sabiam que a categoria petroleira reconhecia os avanços trazidos pelos sindicalistas comandados por Osvaldo Marques e Mário Lima e que este era o seu referencial do bom sindicalismo. Infelizmente não foi possível localizarmos informações sobre o desenrolar da solicitação apresentada pelos dois trabalhadores.

É evidente, no entanto, que os tempos que sucederam à queda dos líderes sindicais trouxeram mudanças no mundo do trabalho petroleiro baiano. Muito embora as vantagens salariais obtidas entre 1960 e 1962 continuassem garantidas, os trabalhadores amargaram tempos mais duros nas relações de trabalho. O fim das comissóes paritárias de disciplina e a volta do poder dos engenheiros de interferir mais diretamente nas questões disciplinares foi visto pelos trabalhadores como uma derrota. A perda de uma série de benefícios que não estavam garantidos por nenhuma convenção de trabalho, e o clima militarizado que as unidades de trabalho voltaram a ter, colaboraram para a construção da imagem de um verdadeiro refluxo nas relações de trabalho dentro da Petrobrás na Bahia.

\section{Conclusão}

O golpe civil-militar de abril de 1964 interrompeu uma trajetória sindical marcada pela articulação entre demandas cotidianas do mundo do trabalho e bandeiras políticas de caráter nacionalista. A força que a repressão usou para tirar de cena as lideranças petroleiras demonstra a relevância política das duas entidades de classe e o risco que elas representavam para o projeto político que a direita organizada e os militares planejaram para o país no alvorecer de 1964. Neste caso, faz bastante sentido a tese defendida por Toledo, que considera que a intervenção que derrubou Jango do poder tinha os grupos políticos que defendiam as reformas de base como principais inimigos (TOLEDO, 2004). Ademais, o seu principal resultado foi a interrupção de uma experiência democrática, que possibilitou a participação política de setores tradicionalmente excluídos desse cenário.

O efeito visível da repressão sobre os sindicalistas ajuda a explicar o refluxo das mobilizações operárias do imediato pós-golpe. Era um grande risco 
para chefes de família a aventura política que poderia resultar em demissões, prisões e perseguições. A preocupação com o sustento de esposa e filhos aumentava os efeitos nocivos de possíveis prisões e demissões. Mesmo assim, a experiência da "era de ouro" do movimento sindical petroleiro, sobretudo nas questôes voltadas para o ambiente de trabalho, deixou um legado marcante para os trabalhadores da Refinaria de Mataripe e da Região de Produção.

Por isso mesmo, não podemos dizer que atividades associativas e demonstrações de solidariedade de classe esvaíram-se por causa da repressão. Enquanto muitos líderes sindicais estavam sendo presos e tantos outros preferiram abandonar a empresa por causa do clima instalado no imediato pósgolpe, os petroleiros que continuavam em seu local de trabalho organizavam sem a participação da interventoria sindical - listas de auxílio para as famílias dos demitidos e perseguidos políticos. Outros levavam alimentos para os próprios fugitivos, que permaneciam escondidos próximos aos locais de trabalho. Ademais, pouco tempo depois, já começavam a ensaiar os primeiros passos para a reorganização de suas atividades.

Três anos após o golpe, no início de 1967, Marival Caldas, Primeiro Secretário da nova direção sindical, publicou através do Sindipetro - Jornal uma nota intitulada "O carrapato". Nela, o sindicalista fazia um pequeno balanço da situação dos petroleiros desde 1964. Na ocasião, o sindicalista perguntou-se: "o que melhorou na Refinaria após a Revolução?”. Sua resposta foi desanimadora. Segundo sua avaliação, toda a parte social e salarial da empresa havia refluído após a "redentora". Marival dizia que o sindicato, após a sua liberação, "passou a trabalhar reivindicando e procurando dialogar com as autoridades civis e militares". Contudo, era recebido e tratado "com desprezo e descrédito". Para ele, restava aos trabalhadores se unirem em prol "dos verdadeiros defensores da empresa: o operário [sic]". Estes, deveriam continuar "defendendo a Petrobras", pois com isso estariam "defendendo seu emprego, sua família e o nosso Brasil" ${ }^{20}$. Permanecia para essa nova geração de sindicalistas a defesa da empresa como forma de garantir ampliação de direitos para os trabalhadores. Além disso, os militares recebiam as primeiras críticas oficiais da representação oficial da categoria. Contudo, os tempos eram outros e o diálogo entre empresa e operários muito mais difícil. Entre abrir espaço para os sindicalistas e cercear sua liberdade, os militares - como não é de se estranhar - recorreram à segunda opção. A certeza da inviabilidade de um projeto de país que incorporasse demandas da classe trabalhadora fez com que os novos comandantes do país recorressem, em diversas oportunidades, à repressão e à

20 “O Carrapato". Sindipetro Jornal, p. 12, v. 1, n. 7, 1967. 
intervenção, demonstrando que a suposta preocupação democrática que os moveu contra o governo Goulart e seus aliados, no mundo sindical não passou de um discurso habilmente montado para falsear interesses muito menos legítimos.

\section{REFERÊNCIAS}

DIAS, José Alves. A subversão da ordem: manifestaçōes de rebeldia contra o Regime Militar na Bahia (1964-1968). Dissertação (Mestrado em História) - Faculdade de Filosofia e Ciências Humanas - Universidade Federal da Bahia, Salvador, 2001.

IVO, Alex de Souza. Uma história em verde, amarelo e negro: classe operária, trabalho e sindicalismo na indústria do petróleo (1949-1964). Dissertação (Mestrado em História) Faculdade de Filosofia e Ciências Humanas - Universidade Federal da Bahia, Salvador, 2008.

FERREIRA, Jorge. O governo Goulart e o golpe civil-militar de 1964. In: FERREIRA, Jorge; DELGADO, Lucília de Almeida Neves. O Brasil Republicano; o tempo da experiência democrática: de 1945 ao golpe civil-militar de 1964. Rio de Janeiro, Civilização Brasileira, 2003.

MANGABEIRA, Francisco. Imperialismo, petróleo, Petrobrás. Rio de Janeiro: Jorge Zahar, 1964.

MORAES, Maria Lygia Quartin de. O golpe de 1964: testemunho de uma geração. In: REIS FILHO, Daniel Aarão; RIDENTI, Marcelo; MOTTA, Rodrigo Patto Sá (Org.). $O$ golpe e a ditadura militar: quarenta anos depois. Bauru: Edusc, 2004. p. 297-314.

OLIVEIRA JR., Franklin. A usina dos sonhos: sindicalismo petroleiro na Bahia (19541964). Salvador: EGBA, 1996.

TOLEDO, Caio Navarro de. 1964: o Golpe contra as reformas e a democracia. In: REIS FILHO, Daniel Aarão; RIDENTI, Marcelo; MOTTA, Rodrigo Patto Sá (Org.). O golpe e a ditadura militar: quarenta anos depois. Bauru: Edusc, 2004. p. 67-77. 


\section{4 \\ O golpe de 1964 e as dimensões da repressão em vitória da conquista}

José Alves Dias ${ }^{1}$

Em 1962, Lomanto Júnior foi eleito governador da Bahia por uma coalizão que trafegava da União Democrática Nacional (UDN) ao Partido Trabalhista Brasileiro (PTB), contudo, apesar do amplo espectro, ela não garantia nem aqui e nem alhures a força necessária para que ele fizesse um mandato excepcional. Paralelamente à instabilidade política, desenhou-se, também, um panorama econômico bastante difícil provocado por períodos de longa estiagem que se alternavam com chuvas torrenciais, prejudicando a agricultura, o principal elemento da economia baiana.

$\mathrm{O}$ apoio do governo federal nessa situação seria imprescindível e do mesmo modo que no dia 13 de março de 1964 as ideias reformistas do presidente João Goulart empolgaram a assistência da Central do Brasil, no Rio de Janeiro acreditava-se no sucesso do comício em Salvador, previsto para o dia 19 de abril do mesmo ano. O governador Lomanto Júnior e vários prefeitos enxergavam nessa visita a oportunidade para auferir os recursos necessários ao desenvolvimento em áreas estratégicas na Bahia.

No início de 1964, o golpe, anunciado aos quatro ventos, ainda parecia inexequível em curto prazo. E a ideia ainda estava, realmente, imatura, quan-

${ }^{1}$ Doutor em História Social e Professor do Departamento de História da Universidade Estadual do Sudoeste da Bahia (UESB). 
do a conjunção de vários fatores e a precipitação do governador Magalhães Pinto obrigaram os quartéis a se mobilizarem. Uma vez consumado o fato, estabeleceu-se uma nova correlação de forças políticas dentro da nova ordem.

Para tanto, é certo que o desconhecimento dos militares quanto à dimensão real da oposição ao movimento golpista favoreceu as delaçôes e a eclosão de antigas intrigas entre adversários políticos na capital e em muitos municípios do interior. Prefeitos como Virgildásio Senna “em Salvador", Francisco Pinto "em Feira de Santana", Murilo Cavalcante "em Alagoinhas", José Pedral “em Vitória da Conquista”, se somam a tantos outros que viveram a experiência da perseguição, da cassação e do dano aos direitos políticos nesse período tenebroso. De certo modo, esses aspectos da nossa história recente ainda são desconhecidos.

Contudo, a ampliação dos debates em torno do golpe de 1964, e da ditadura que se instaurou em seguida, tem permitido que o aspecto local seja abordado com maior frequência e aprofundamento, descentralizando a história política brasileira dos maiores centros urbanos e dos personagens mais conhecidos. Desse modo, o conjunto da historiografia brasileira desse período vai se enriquecendo com a descoberta dessas experiências de pesquisa e a sociedade passa a ter uma ideia de conjunto, como também, alguns parâmetros de comparação para ajuizar o recente passado da nossa política.

No intuito de colaborar com essa pesquisa, este texto pretende reconstituir parte do processo de interiorização da ação repressiva ocorrida na Bahia imediatamente após o golpe de março de 1964. Referenciando-se nos depoimentos do ex-prefeito de Vitória da Conquista, Pedral Sampaio, recuaremos aos primeiros dias do golpe na cidade, recorrendo, por vezes, a outras experiências semelhantes. ${ }^{2}$

\section{A polarização de ideias}

A disputa pelo poder local entre grupos políticos no município de Vitória da Conquista e em seu entorno é bastante antiga. Numa linha de tempo bem distante, encontramos João Gonçalves da Costa, latifundiário e capitão responsável pela ocupação portuguesa na região, indispondo-se com o governo provincial e os membros do poder judiciário em virtude de causas jurídicas ou de caráter administrativo. A historiadora Maria Aparecida Silva de Sousa, ainda que buscasse realçar o poderio econômico do sertanista, não deixou de

${ }^{2}$ O Depoimento de José Fernandes Pedral Sampaio foi gravado para o autor entre os dias 15 e 20 de julho de 1999. 
notar a importância desse aspecto para o reconhecimento de sua autoridade política pela Coroa Portuguesa e "ressaltar que a ausência de participação expressiva de João Gonçalves da Costa na política local e regional não se aplica a alguns membros de sua família”. A autora dizia respeito, obviamente, aos seus filhos, netos e aparentados que, nos séculos subsequentes, ocupariam cargos importantes na Imperial Vila da Vitória e disputariam ascendência sobre povoados agregados e potencialmente emancipáveis. (SOUSA, 2001, p. 114, 153, 184-185)

O confronto entre o Santo Lenho e o Anjo da Morte, descrição primorosa de Isnara Pereira Ivo sobre a tragédia do Tamanduá, em 1895, mostra a interseção entre o público e o privado nas disputas locais:

Na Imperial Vila da Vitória, onde os membros da justiça eram todos parentes, é fácil compreender como qualquer questiúncula ou pequena querela do mundo privado poderia ser estendida ás instâncias públicas. Era perfeitamente possível um assunto de polícia ser tratado como assunto de família, ou um assunto de família ser encarado como um problema de cunho policial, ficando difícil perceber onde começava a ação da justiça, do poder público, e onde terminava uma questão de caráter privado. (IVO, 2004, p. 157)

A convicção de que o domínio econômico, por meio dos latifúndios, foi estratégia da elite local, em tempos remotos, para garantir a autoridade política com aquiescência portuguesa, e o controle das demais instâncias de poder aparece ainda em um artigo de Isnara Ivo, cujo foco de análise é mais amplo e conclui com a hipótese de que:

As grandes famílias tradicionais, entendidas aqui como as famílias que controlaram as posiçóes de poder no município desde o processo de conquista da região, não conseguiram construir um líder forte que fosse capaz de dirigir a atuação política dos membros do grupo familiar e dos correligionários em geral. A longa dominação familiar foi garantida pelo entrelaçamento familiar e pelo número de membros da família que controlavam determinadas regiões do município. As famílias não conseguiram extrapolar esses limites e projetar-se em nível estadual, ao contrário de outras famílias do interior do estado. O mandonismo 
local na Imperial Vila da Vitória e, posteriormente, na cidade de Conquista esteve imerso nas disputas locais e nos confrontos familiares que marcaram a história da cidade, cujo ápice foi a tragédia do Tamanduá, em 1895. (IVO, 1999, p. 85)

Para ilustrar ainda o controle do poder público pela elite local dominante e acentuar a percepção sobre o impacto dessa situação no conjunto das ações políticas no âmbito municipal, convém observar a reflexão de Humberto José Fonseca a esse respeito:

As estruturas políticas e administrativas do Estado Imperial permitiram que, nas localidades, grupos políticos divergentes usassem da violência como meio de apoderar-se das esferas do poder municipal. Apesar de o Estado ter desenvolvido mecanismos e canais de centralização político-administrativa, essa orientação era de pouca eficácia sobre a vida do município, em função da capacidade da elite de gerenciar autonomamente, o poder local. (FONSECA, 1999, p. 30-31)

Finalmente, vejamos os desdobramentos desse processo de articulação ou conflito entre famílias da região no período republicano pela narrativa de Belarmino de Jesus Souza. De algum modo, essa genealogia do poder convergiu para José Pedral Sampaio como descrito a seguir:

No novo contexto republicano, despontaram lideranças no seio das parentelas conquistenses. As principais lideranças foram os coronéis Francisco José dos Santos Silva (conhecido com Chico Santos) e José Fernandes de Oliveira (conhecido como coronel Gugé). O primeiro, nascido em 1848, era filho dos fundadores da família Santos, Manoel José dos Santos Silva e Ana Angélica de Lima, casal que teve seis dos seus nove filhos e filhas casados com pessoas da família Fernandes de Oliveira. O segundo era filho Luiz Fernandes de Oliveira e Tereza de Oliveira Freitas (neta do bandeirante João Gonçalves da Costa) nascido em 1844. A família Fernandes Oliveira formava o tronco inicial e principal, ao qual, as outras famílias que formariam a endogamia conquistense, se vincularam. 
O pai de José Fernandes de Oliveira foi membro da primeira Câmara instalada na cidade, quando da emancipação em 1840. (SOUZA, 1999, p. 104 -105)

Ainda segundo o autor supra citado, outra importante facção política era coordenada pelos coronéis Pompílio Nunes e Manoel Moreira. Os dois grupos receberam denominações curiosas: os peduros, alinhados do coronel Gugé e os meletes, correligionários dos coronéis Manoel Moreira e Pompílio Nunes. ${ }^{3}$

Francisco José dos Santos Silva, José Fernandes de Oliveira e os dois últimos coronéis aqui citados eram filiados ao Partido Republicano Democrático da Bahia. Essa é uma característica bastante corriqueira quando os grupos locais dependem das instâncias administrativamente superiores do poder. Nesse caso, realça o historiador, tanto uns quanto outros careciam de apoio do governador José Joaquim Seabra para garantir a viabilidade de sua existência política no município e, por isso, mantinham-se no partido da situação.

Ocorre que dois fatos distintos contribuíram para mais um conflito intraelites: a curva decrescente da influência seabrista no Muniz Aragão (1916/ 1920) e a morte de José Fernandes Oliveira em 1918. O coronel Gugé atuava como o fiel da balança na convivência entre opositores dentro do diretório local do seu partido, relata Belarmino de Jesus Souza, e seu desaparecimento conjugado com a fraca atuação do governador Aragão na unidade partidária provoca a exclusão do grupo Pompílio Nunes e Maneca Moreira do partido. A crise provocada pela cisão do $\mathrm{PRDB}$ vai se configurar numa grave crise política e num confronto violento no centro da cidade, apenas apaziguado dias depois.

Apesar de um acordo selado entre as partes beligerantes e da fragmentação política de ambos os grupos após o conflito, não se dissolveram os ressentimentos que instigaram a guerra entre meletes e peduros. Na década de 1930, Luiz Régis Pacheco retomou o controle político e tornou-se uma liderança regional com projeção, também, em nível nacional no Partido Social Democrático (PSD). Na década de 1960, estavam nesse mesmo partido o médico Régis Pacheco e o engenheiro José Pedral Sampaio disputando com Gerson Sales a hegemonia política em Vitória da Conquista.

No período imediatamente anterior à mais recente ditadura brasileira, a polarização ocorre de fato nas eleições municipais de 1962. Como de costume, não se percebiam diferenças ideológicas substanciais entre Jesus Gomes dos

\footnotetext{
${ }^{3}$ Entre diversas explicações para as alcunhas recebidas pelos grupos, uma delas supõe-se que se fizessem referência à qualidade do gado peduro (misto) e melete (raça) que compunham a maioria do rebanho de cada um dos proprietários citados.
} 
Santos (UDN/PRP) e José Fernandes Pedral Sampaio (PSD/MTR), os principais candidatos - embora isso seja discutível se, além do aspecto teórico, forem configuradas a posição dos sujeitos na correlação de forças políticas e sociais. Isso porque, além das tensóes provocadas pela derrota de Pedral, em 1958, que alimentava as refregas entre os aliados de Gerson Sales e os correligionários de Régis Pacheco, esses setores se distinguiam por sua posição diante das reformas sociais impostas pelas pressões populares e canalizadas habilmente para o governo pelos dirigentes populistas da época. ${ }^{4}$

A proposta reformista entusiasmou Pedral e seu grupo político que, embora oriundos do coronelismo, compreendiam a necessidade de inserção do município dentro da estrutura política e econômica do país que acompanhava as atualizações do capitalismo ocidental. Inquirido sobre as obras que viabilizou durante seu primeiro mandato como prefeito, ele disse:

Fizemos novos métodos de governo, e modernizamos logo a cidade. Comprei máquinas. Não tinha um carro na prefeitura! Eu comprei uma camionete e tratores. Não tínhamos água, nem esgotamento, nem telefone. Não tínhamos nada, éramos uma vila. Eu sabia da potencialidade de Conquista por ser um caminho bem situado, clima bom, passagem do São Francisco para Ilhéus. Então, consegui fazer muita coisa. Nesse tempo, era João Goulart, Brizola, as heranças de Getúlio, a juventude muito entusiasmada. Nós, na realidade, embarcamos no projeto de Goulart para fazer as reformas de base: reforma do sistema bancário, reforma agrária, urbana e da educação. (SAMPAIO, 2008, p. 12)

Pedral havia sido derrotado nas eleições de 03 de outubro de 1958 para Gerson Sales, e percebeu que a grande força eleitoral do grupo adversário era a zona rural do município. Conseguira um bom êxito urbano, mas, Gerson

\footnotetext{
${ }^{4}$ Nas eleições municipais de 1962 foram candidatos: Jesus Gomes dos Santos, através de uma coligação estabelecida entre a Uniāo Democrática Nacional (UDN) e Partido Republicano Progressista (PRP); José Fernandes Pedral Sampaio, por meio da aliança entre Partido Social Democrático (PSD) e o Movimento Trabalhista Renovador (MTR); Hugo de Castro Lima, pelo PTB de Getúlio Vargas; Jorge Stolz Dias, candidato do Partido Social Progressista (PSP) e Edmundo Santos. O PSD, fundado em 1945, por ex-interventores de Getúlio Vargas, obteve desempenho considerável durante o período Juscelino Kubitschek. O MTR foi uma dissidência do Partido Trabalhista Brasileiro (PTB), liderada pelo deputado Federal Gaúcho Fernando Ferrari, dedicada a combater o governo Vargas e o pacto entre ele as oligarquias rurais. O PRP foi fundando por Ademar de Barros em 1945 e o PSP surgiu de uma fusão entre parte do PRP e dois outros partidos em 1946.
}

${ }^{5}$ Entrevista concedida a Thaiane Firmino. 
Sales ampliara sua margem de votos nos distritos e alcançou o número de 1.888 votos a mais na contagem final. A primeira providência foi pressionar o legislativo, com apoio do vereador Alberto Farias, para emancipação dos maiores distritos e investir na politização dos eleitores através do jornal $O$ Conquistense e outros meios de divulgação. A estratégia de Gerson Sales foi cooptar o poeta Jesus Gomes dos Santos e apresentá-lo como candidato para dividir o grupo adversário. Ruy Medeiros descreve essa situação:

À medida que iam aproximando-se as eleições de 1962, a situação foi complicando-se para Gerson Sales. Este e seu grupo optaram por tentar dividir a oposição. Finalmente, o candidato apresentado pelas forças "gersistas" foi um vereador que houvera militado na oposição: Jesus Gomes dos Santos, poeta. Sim, o poeta de "Maria Guabiraba" e da "Procissão", poesias que lhe causaram dor de cabeça durante as eleições, por seu conteúdo social. (MEDEIROS, 1999, p. 14)

A noção que Pedral possuía sobre a política local naquele momento fez muito sentido para a estratégia da "campanha da esperança":

Em 1958 nós disputamos uma eleição aqui em Conquista que era uma pequena cidade, pouco desenvolvida. Mas eu estava mais interessado em formar um grupo político, com uma turma nova que começou a combater o conservadorismo, aquela inércia que existia na administração municipal. Na realidade era um discurso de modernização e desenvolvimento. Naquele ano de 1958, nos ganhamos na cidade e perdemos nos distritos. Veio então a ideia de emancipar os distritos, os candidatos a prefeito, através do Padre Palmeiras, que era deputado estadual e a gente conseguiu emancipar Barra do Choça, Caatiba, Anagé, Belo Campo e Cândido Sales. Nós, então, partimos com muita força para a eleição de 1962. Um grupo bem organizado, uma turma muito jovem e a cidade querendo ver um sentido, entendendo o discurso de que não se podia continuar numa política daquela, no município. Então a Campanha da Esperança foi feita numa base, segundo a qual, realmente, nos tiraríamos o símbolo conservador do poder público. O objetivo era projetar Con- 
quista no cenário do Estado e ganhar a eleição de 1962, a gente partiu para criar associaçōes de bairros no interior e na cidade. Ajudamos na organização dos sindicatos. Nós envolvemos, mesmo, a cidade na ideia nova. Além de ajudar na organização dos sindicatos, nós nos aproximamos bem da população rural, da câmara de vereadores, da situação do ensino, do clube de diretores lojistas, da Igreja dos Capuchinhos, da união com os estudantes, dos grêmios literários, da Rádio Clube, da Rádio Regional, dos sindicatos da construção civil, da associação de rádio difusão, do centro de assistência social, da liga de esportes, do grêmio atlético, do sindicato dos comerciários e de tudo que existia de organizado ou estávamos organizando em 1962. O discurso de que a cidade precisava ter água, esgoto, energia, estradas, cuidar do homem do interior, sensibilizou completamente a cidade e nós ganhamos com certa facilidade as eleiçôes. ${ }^{6}$

Foram exatamente o posicionamento favorável de prefeitos do interior da Bahia às reformas de base do presidente João Goulart e a tentativa de aproximação de alguns deles com os movimentos populares que despertaram a atenção do comandante Manuel Mendes Pereira - responsável pela coordenação e execução das ações repressivas no interior -, da 6. ${ }^{a}$ Região Militar, em Salvador. Portanto, há duas dimensões na interiorização da repressão: a resultante da delação e outra motivada pelo conteúdo político e doutrinário das gestôes administrativas municipais. Embora independentes, essas dimensões são complementares e por vezes se confundem, mas são bastante visíveis no comentário do ex-prefeito de Conquista:

O governo de João Goulart foi muito tumultuado [...] João Goulart veio aqui, nós tínhamos perdido a campanha de 58 e nos aproximamos do vice-presidente. Nós nos engajamos completamente nas lutas pelas reformas. Estávamos convencidos de que o país necessitava, e urgentemente, das reformas pregadas, com ênfase para reforma do campo. Dávamos uma importância muito grande à reforma agrária, mas sabíamos da necessidade da remessa de lucro para o exterior, de todo tipo de reforma que era pregada, na educação, na condução das coisas

\footnotetext{
${ }^{6}$ José Fernandes Pedral Sampaio. Entrevista ao autor, Vitória da Conquista, dezembro de 1999.
} 
políticas. E nós então nos aproximamos demais dessa situação. Fizemos uma grande politização na cidade. Chegamos até a dizer mesmo, que a fase de maior politização na nossa cidade foi exatamente nessa época, na época das reformas de João Goulart. ${ }^{7}$

Naquele momento, a cidade confirmava a sua tradição de entroncamento rodoviário com a inauguração da rodovia que ligava Salvador ao Rio de Janeiro. O evento adquiriu tanta importância que o presidente João Goulart, pessoalmente, veio prestigiar a solenidade realizada na divisa dos estados da Bahia e Minas Gerais. Logo depois, a convite das autoridades locais, visitou Vitória da Conquista e foi a primeira vez que a cidade recebeu um presidente da República. José Pedral fala com orgulho desse evento festivo:

Por exemplo, participou dessa inauguração o governador de Minas Gerais, o governador Arraes de Pernambuco, o governador da Bahia que era Lomanto Júnior, uma porção de autoridades, acompanhou João Goulart aqui nessa inauguração. Mas nós tínhamos conseguido que depois da inauguração o João Goulart viesse a Conquista e veio. Nós fizemos uma reunião, teve na realidade um churrasco aqui na sede do DNER e ele foi até o parque de exposição de pecuária onde pronunciou o discurso, onde eu fiz um discurso, mas aí foi feita uma grande mobilização na cidade. A coisa, talvez, mais importante que já se fez em Conquista, em termos de mobilização na cidade, foi nessa vinda de João Goulart, que nós enchemos a rua, todas as escolas, com as crianças todas com uma placa dizendo água, água, água e realmente ele se comprometeu e fez. ${ }^{8}$

E a emenda, destinando para o município um terço da verba de saneamento disponível, foi feita imediatamente pelo senador Aloísio de Carvalho naquele ano de 1963. O prefeito, então, coordenou as obras para o abastecimento de água encanada nas casas, até então, servidas por poços artesianos e fossas. Empolgado pelo resultado, Pedral procurou o ministro de Minas e Energia e conseguiu um motor elétrico para aumentar a vazão de água na tubula-

${ }^{7}$ José Pedral Sampaio, 1999. Depoimento ao autor.

${ }^{8}$ José Pedral Sampaio, 1999. Depoimento ao autor. 
ção. A instalação da vara da Justiça do Trabalho, também, é reivindicada pelo prefeito como esforço de sua administração. Essa medida, segundo ele, trouxe preocupação aos proprietários rurais e grandes comerciantes locais.

Nesse ponto, Pedral é enfático ao dizer que o reformismo estimulava a politização dos trabalhadores no interior. Parece razoável acreditar nessa assertiva em virtude do desempenho quantitativo e qualitativo das manifestaçóes populares em todo país no entorno de 1964. Entretanto, a politização foi, prioritariamente, resultado das demandas populares reprimidas durante décadas e da organização desses setores em função das brechas abertas pelo populismo. Conforma-se, então, a percepção da difusão do projeto de desenvolvimento liberal nacionalista e a ampliação dos espaços políticos na administração do prefeito de Conquista em consonância com as ideias do governo João Goulart.

Como visto anteriormente, a deposição do prefeito conquistense, associado aos conflitos locais seculares, se configurou como uma punição à sua associação às propostas reformistas em curso naquele momento.

\section{Os efeitos políticos da crise}

Nas eleições de 1960, Jânio Quadros foi eleito presidente da República e João Goulart vice-presidente, embora fossem de coligações opostas, uma vez que a legislação eleitoral da época permitia eleições separadas para os dois cargos. Jango era um grande latifundiário, proprietário de uma extensa faixa de terras no Rio Grande do Sul, e proveniente da oligarquia agrária gaúcha. Portanto, não restam dúvidas quanto a sua origem social e os interesses que defenderia prioritariamente. Entretanto, nos cargos públicos que ocupou, sempre protegeu a liberdade individual, a participação política universal e o funcionamento regular das instituições democráticas.

Essas foram características dessa elite que possuía um projeto político reformador e uma estratégia econômica com fortes traços liberais, contudo, paradoxalmente nacionalista e resguardada por um Estado regulador e assistencialista. Seus principais adversários eram políticos, empresários e militares conservadores no campo político e economicamente atrelados ao liberalismo globalizante e desenvolvimentista. As reformas políticas em curso naquele momento possibilitavam uma ampliação da participação popular nas decisões políticas, embora, monitoradas e controladas pelo governo e pela elite. Por outro lado, estavam no encalço do desenvolvimento urbanizado e industrializado, porém resguardando as prerrogativas do empresariado nacional. 
Ao contrário, os opositores de João Goulart e Leonel Brizola pretendiam estabelecer um projeto desenvolvimentista com a abertura do país ao mercado internacional, o controle da inflação e endividamento externo para financiar o progresso pretendido. ${ }^{9}$

Estavam, portanto, em conflito no Brasil pelo menos dois grandes projetos de desenvolvimento econômico e participação política. Do ponto de vista econômico não estavam muito distantes, pois ambos ambicionavam um país industrializado, urbanizado e dinâmico. As divergências surgiam a respeito da política externa - especialmente com Cuba, China, União Soviética e Estados Unidos -, da participação do capital estrangeiro naquele estágio de desenvolvimento e, no plano interno, da forma e da intensidade com que os setores populares eram estimulados a intervir nas decisões da macro política nacional.

Essa disputa entre as duas perspectivas permeou o governo, o legislativo e todos os demais setores da sociedade brasileira nos anos 60 e subsequentes. No Congresso Nacional, as agremiações partidárias, ressalvadas suas divergências internas, se posicionaram de forma inequívoca a respeito. Uma parte do PSD, que aproximava as oligarquias regionais do Partido Trabalhista Brasileiro (PTB) e de Jango, foi progressivamente se distanciando deste último e aderindo organicamente ao golpe contra o presidente. Assim, de forma confusa, os simpatizantes do governo federal em Vitória da Conquista se viram envolvidos na complexa conjuntura do golpe de 1964.

Consumado o golpe e definidas as primeiras medidas de "saneamento" da política interna, o capitão Bendochi, udenista e lacerdista convicto, foi designado para coordenar a prisão e a deposição dos adversários em Vitória da Conquista. As prisões do prefeito e de algumas dezenas de pessoas, entre os quais vereadores de sua base de apoio, foram providenciadas imediatamente. Segundo José Pedral, também foram presos com ele ou ouvidos em inquérito: Franklin Ferraz Neto, advogado que apresentou e conseguiu, em conjunto com o prefeito, a instalação da vara da Justiça do Trabalho e foi nomeado seu primeiro juiz. Este morreu antes de seu julgamento na Justiça Militar; Hugo de Castro Lima, médico oftalmologista, político e candidato pelo PTB nas eleiçôes de 1962; Ivo Freire de Aguiar, mineiro, funcionário do Ministério da Agricultura, presidente da Cooperativa Mista e Agropecuária de Conquista, comerciante de laticínios e proprietário de uma oficina de eletrodomésticos.

\footnotetext{
${ }^{9}$ Leonel de Moura Brizola atuou na política brasileira durante várias décadas. Manteve ligações políticas e pessoais com Getúlio Vargas e comandou em 1964, no Rio Grande do Sul, a resistência ao golpe contra João Goulart. Disputou e venceu diversos pleitos políticos em eleições para deputado estadual, deputado federal e governador nos estados do Rio Grande do Sul, Guanabara e Rio de Janeiro, como também foi duas vezes candidato derrotado em eleições presidenciais.
} 
Entre eles, também estavam o professor Everardo Públio de Castro, um comunista convicto; Camilo de Jesus Lima, poeta, escritor, oficial do registro de imóveis em Macarani e secretário da prefeitura no mandato de Régis Pacheco; Emetério Alves Pereira, também comunista e comerciante de livros; João Idelfonso, uma espécie de publicitário e eletrotécnico; Érico Aguiar, comerciante e marceneiro; Raimundo Pinto, comerciante de material elétrico e produtos eletrônicos; Reginaldo Santos, diretor do jornal $O$ Combate e funcionário do Banco do Brasil; Cláudio Fonseca, estudante e hoje advogado; Vicente Quadros, comerciante; Gilson Moura, radialista; Galdino Lourenço, taxista; Juracy Lourenço, filho deste, comerciário; Jackson Fonseca, radiotécnico; Lúcio Carlos, também funcionário do Banco do Brasil; Luiz Caires Tunes, estudante; Atenor Lima, também estudante e comerciário; Alberto Farias, médico e major da polícia militar. Claudelino Araújo, presidente da Frente de Libertação Nacional na cidade, fugiu para o Rio Grande do Sul antes de ser preso.

A Câmara Municipal foi coagida a votar a cassação do mandato de José Pedral sob vigilância armada. Os edis, aliados ao prefeito, foram afastados e os suplentes foram arbitrariamente convocados. Os vereadores presos foram: Péricles Gusmão Régis, conquistense, comerciário do setor de transportes, vereador e líder do prefeito; Anfilófio Pedral Sampaio, irmão do prefeito, agrônomo, vereador e professor da Escola Normal; Aníbal Lopes Viana, proprietário de jornal, escritor e suplente de vereador; Raul Ferraz, conquistense e candidato a vereador em 1962.

Os militantes estudantis e sindicais tiveram o mesmo destino: Paulo Demócrito, estudante e líder estudantil; Flávio Viana de Jesus, artista em madeira, diretor do sindicato da construção civil; Alcides Barbosa, presidente do sindicato dos comerciários; Altino Pereira, presidente do sindicato dos trabalhadores da construção civil; Edvaldo Silva, presidente da associação de panificadores; José Luiz Santa Isabel, funcionário do Banco do Brasil e membro do sindicato dos bancários.

Em lugar de Pedral Sampaio assumiu o presidente do Legislativo Orlando Leite. Além de cassado e ter os direitos políticos suspensos por dez anos, o prefeito se queixa de outras consequências refletidas na vida pessoal e profissional:

Basta dizer que, com a suspensão de direitos políticos eu não podia ser professor, não podia ter emprego público, não podia entrar em concorrência pública nenhuma, não podia tomar dinheiro em banco oficial. Isso não era ostensivo, mas os próprios gerentes dos bancos oficiais me 
mostraram instruções internas de que não podiam fazer nenhuma operação bancária com quem tivesse os direitos políticos cassados e, no caso, era eu o atingido. Então, era realmente muito difícil sobreviver com uma pressão dessas, com o controle, com a vigilância terrível que eles faziam em toda movimentação da qual eu participava. ${ }^{10}$

Pedral não tem dúvidas que o histórico de conflitos entre grupos políticos antagônicos no município de Conquista, especialmente aqueles que se configuraram no momento de sua eleição em 1962, foi decisivo para que o capitão Antônio Bendochi chegasse à cidade com a determinação de prendêlo. A dimensão da delação e da intriga é vista pelo depoente da seguinte forma:

Os opositores ficaram amedrontados com a maneira como eu desenvolvi a cidade. Um pouco antes do golpe, até uma reunião foi feita aqui, no cinema, que repercutiu muito. Eles estavam comprando armas em toda região: Ilhéus, Itapetinga, Brumado, Itambé, Macarani, em toda essa região o pessoal estava se armando muito contra o governo João Goulart. ${ }^{11}$

A narrativa da prisão de José Pedral exterioriza a sua revolta com aquilo que ele considerou um ritual de intimidação e, ao mesmo tempo, de demonstração ostensiva de força e atuação "pedagógica" do autoritarismo:

A minha prisão foi uma traição, como praticamente tudo que foi feito nesse golpe militar. De manhãzinha, eu tive notícia de que tinha chegado uma companhia. Vieram cem homens do exército, muito armados, muitas metralhadoras, pra humilhar mesmo a cidade. Eu soube que eles estavam aqui e me aprontei pra ir ao quartel. Quando saí, defronte da minha casa, a tropa estava parada ali, o capitão Bendochi e outros militares. Eu passei, cumprimentei e disse até que ia fazer uma visita lá no quartel. Ele disse: ah! O senhor vai? Então "vum bora pra lá". Na mesma hora entraram dois tenentes no meu carro e a gente seguiu até lá no quartel, que é, hoje, o Batalhão Militar.

${ }^{10}$ José Pedral Sampaio, 1999. Depoimento ao autor.

${ }^{11}$ Ibidem. 
Lá, mandaram eu me identificar e, imediatamente, disseram que eu estava preso e me transferiram para uma cela onde eu fiquei incomunicável. Eles me mantiveram pelo menos umas trinta e seis ou quarenta e oito horas incomunicável, sem fornecer, inclusive, alimentação. ${ }^{12}$

Na prisão não faltaram experiências de medo, constrangimento e violência psicológica. O estudante e comerciante Vicente Quadros contou a Pedral que fora submetido a um tipo de tortura que se tornou muito comum nos anos seguintes: aplicaram-lhe um "soro da verdade", coagindo-lhe a denunciar os companheiros. Essa técnica consistia em fragilizar a pessoa e, depois, colocálo na cela para que, com sua experiência, os demais ficassem aterrorizados. Por causa disso, Péricles Gusmão Régis, vereador e líder do prefeito no legislativo municipal, foi encontrado com os pulsos cortados em sua cela.

Depois de uma triagem preliminar, os presos foram encaminhados para Salvador a fim de responderem ao processo na Justiça Militar. Além de Pedral, foram encaminhados, também, Anfilófio Pedral, o professor Everardo Públio de Castro e o Dr. Franklin Ferraz. Além desses quatro, vários outros foram ouvidos em quartéis diferentes da capital baiana. As principais acusações contra o prefeito eram: compor o Grupo dos Onze, núcleos organizados por Brizola; participar da Frente de Libertação Nacional, que seria liderada por Waldir Pires; provocar agitação no país e de estar se preparando militarmente para a guerrilha. A denominação do Fórum João Mangabeira, constituída por meio de mensagem de Pedral à Câmara de Vereadores, provocou a desconfiança do capitão. Ele não se convenceu dos motivos apresentados pelo prefeito para homenagear aquele baiano emprestando seu nome à sede do Poder Judiciário, tampouco, das negativas quanto à participação de Pedral nas campanhas de Brizola e Waldir.

Em consequência das denúncias, além do já citado caso do prefeito, Anfilófio Pedral Sampaio foi absolvido ao fim do processo e reassumiu as funções da vereança, entretanto foi punido com a imediata demissão do cargo de professor e, como agrônomo da Secretaria de Agricultura da Bahia, foi transferido para a cidade de Mucuri, uma região inóspita no extremo sul do Estado, local em que estava sendo construída uma estrada de ferro. O Franklin Ferraz faleceu antes do julgamento e, dos quatro, o professor Everardo Públio de Castro foi o único condenado e cumpriu prisão. Os demais não chegaram a responder formalmente a processos ou serem condenados na Justiça Militar.

${ }^{12}$ José Pedral Sampaio, 1999. Depoimento ao autor. 


\section{$\mathrm{O}$ reformismo e as querelas locais}

Pelo exposto, fica evidente que a cassação do prefeito de Vitória da Conquista em 1964, bem como, a prisão e/ou a condenação dos demais envolvidos foram resultados de uma conjunção de fatores cujas origens são dispersas. A disputa entre dois projetos diferentes sustentados pela elite do país e assumidos pelos segmentos congêneres no município é elemento da macro política que converge para o golpe, as prisões, as condenações e a cassação de José Pedral. A política de varejo, neste caso, é oportunista, uma vez que os adversários de 1958 e 1962 se encontram diante de um momento de decisão, oportunizado pelo golpe de 1964, que os possibilita a alterar a correlação de forças na política local sem que para isso fosse necessário um novo pleito eleitoral.

É possível que os desdobramentos da aproximação entre o PSD conquistense e o PTB de João Goulart tenham sido satisfatoriamente explicitados, contudo, resta apreciar em que medida o antagonismo da política local pode ser considerado como um dos fatores determinantes para a cassação do José Pedral Sampaio.

Como visto, as dissensões políticas em Vitória da Conquista sempre tiveram uma motivação particular e, via de regra, originaram-se de conflitos entre famílias tradicionais ou mesmo dentro de uma mesma família que se hostilizavam mutuamente e, não raro, terminavam violentamente.

Com o fim das querelas entre peduros e meletes na década de 1920, Luiz Régis Pacheco Pereira, nascido em Santo Amaro da Purificação e residente em Salvador, veio para o interior e se uniu à família Santos por casamento. Em sua atuação como médico, adquiriu prestígio e respeito dos conquistenses, especialmente, entre os mais pobres. Após o golpe do Estado Novo em 1937, Régis Pacheco foi indicado pelo interventor varguista, Pedro Aleixo, prefeito da cidade de Conquista, onde permaneceu até 1945. Na campanha para as eleiçóes diretas de 1950, nas quais foi eleito governador da Bahia, ele buscou uma composição de suas bases políticas no interior reunindo famílias conquistenses tradicionalmente adversárias e incluindo nesse rol o candidato a prefeito Gerson Gusmão Sales, vitorioso nas urnas pelo PSD.

Segundo Ruy Medeiros, Régis Pacheco foi o mentor e executor de uma composição política que absorveu e pacificou durante muito tempo as rixas políticas de origem familiar existente em Conquista. Assim, diz ele:

O poder ficava mais ou menos equilibrado, porque Régis Pacheco, que havia sido deputado federal constituinte, 
um homem de importância, e logo a seguir governador do Estado, era muito influente. Ora isso, significava que mesmo que outros grupos quisessem tomar as rédeas do poder local de uma maneira muito exclusivista em Conquista, teriam um contrapeso da influência política de Régis Pacheco e seu poder político. ${ }^{13}$

Ao deixar o governo do estado em 1955, Régis Pacheco perdeu parte da influência política e, principalmente, a capacidade de unidade dentro do PSD baiano. Em Vitória da Conquista, principal reduto do governador, as eleiçōes municipais se deram num clima tenso e bastante polarizado dentro do partido. Ao se referir à derrota de Jesus Gomes dos Santos, candidato de Gerson Sales, Ruy Medeiros ressalta que:

Aquelas eleições culminavam um processo de divergências acentuadas entre grupos. Já em 1954, não fora fácil ao grupo de Gerson Sales viabilizar a eleição de Edvaldo de Oliveira Flores. Contra este insurgiu-se mesmo uma parcela do PSD, que resolvera apoiar a candidatura de Nilton Gonçalves, candidato com discurso populista. Foi a campanha do "tostão contra o milhão" que tanto marcou a década de 1950 em Vitória da Conquista. O "tostão" era Nilton Gonçalves e o "milhão" era Edvaldo Oliveira Flores. (MEDEIROS, 1999, p. 14)

O fato concreto a respeito desse momento é que Gerson Sales decidiu não aguardar a determinação do partido e de seu líder e indicou um parente para sua sucessão na prefeitura. Foi o que bastou para o rompimento da unidade partidária e a desagregação do pacto entre as famílias com potencial para decidir as eleições municipais.

Na eleição municipal conquistense de 1958, parte das famílias Gusmão, Sales e Mendes, novamente, acirraram uma disputa exclusivista pelo poder local. O prestígio de Gerson Sales o credenciou ao cargo mais uma vez naquele ano. Entretanto, a sua gestão manteve as características conservadores, exclusivistas e oligarcas que aos poucos começavam a se tornar obsoletas, mesmo para a elite. Por outro lado, as propostas arejadas de José Pedral, que fora derrotado por Gerson Sales em 1958, começaram a despertar a atenção do

\footnotetext{
${ }^{13}$ Ruy Medeiros. Vitória da Conquista, 31 de dezembro de 1997. Depoimento ao autor.
} 
eleitorado conquistense possibilitando uma nova agregação dentro do PSD e a sua rearticulação com outros partidos sob a liderança de Régis Pacheco.

Conquanto essa reorganização pessedista em Vitória da Conquista tenha sido vantajosa para Régis Pacheco e José Pedral em função da vitoriosa campanha de 1962, a extensão dessa aliança teve implicações somente reveladas pelo o golpe de 1964. Antes, porém, é preciso conferir a composição dessa coligação, ainda no depoimento de Ruy Medeiros:

Ligado a essas forças que se opunham a Gusmão havia uma frente que ia desde pessoas da direita, remanescentes do Integralismo, até o pessoal brizolista e o pessoal ligado ao partidão. As bases familiares também eram amplas: parte da família Ferraz, sobretudo os Santos. A Igreja também já se abria um pouco mais, sobretudo os capuchinhos, que eram um pouco mais abertos. Os estudantes organizaram dois grêmios estudantis, na principal escola de toda essa região que era o Instituto de Educação Euclides Dantas, com agitação, com debates, participação na UBES, no congresso da ASES, da União de Estudantes Secundaristas. Havia uma grande agitação dos estudantes com manifestos pela candidatura de Pedral, passeatas e quebra-quebra no Cine Conquista, no Cine Riviera, mas quebra-quebra mesmo, de destruir cadeira, bomboniere, vidraças para de obter meia nos cinemas. Então era um movimento que estava se afirmando naquela época. ${ }^{14}$

Após as eleições para prefeito e vereadores de Vitória da Conquista em 1962, o PTB, derrotado, se compôs com a UDN na Câmara de Vereadores. Isso se explica, em primeiro lugar, pela tendência de amplas associações partidárias que se configuraram naquele pleito para garantir o sucesso eleitoral tendo como exemplo maior a coligação entre Juracy Magalhães (UDN) e Lomanto Júnior (PTB) para viabilizar a candidatura desse último ao governo do estado naquele mesmo ano. Embora isso não seja percebido na relação entre partido e ideologia, as alianças partidárias nesse momento reforçam uma percepção que extrapola o pragmatismo político e mostra a veracidade da disputa entre dois projetos políticos que se disseminavam por todo o país. Muniz Ferreira traçou desse modo, o perfil da composição política que elegeu Lomanto Júnior:

\footnotetext{
${ }^{14}$ Ruy Medeiros. Depoimento ao autor, 1997.
} 
O governo de Antônio Lomanto Júnior se constituiu como resultado do triunfo da coalizão UDN-PTB ${ }^{15}$ sobre o candidato do PSD, Waldir Pires, nas eleições estaduais de 1962. Sustentada pelos círculos conservadores da política e da sociedade civil baiana de então e tendo como "padrinho" eleitoral Juracy Magalhães — na época governador, figura de proa da UDN e adversário declarado do presidente João Goulart - , a candidatura de Lomanto engendrava desde o início o paradoxo de incluir em sua chapa o PTB baiano, partido que, conquanto fosse hegemonizado na Bahia por sua ala menos "progressista", era também o partido do primeiro mandatário da república. Inversamente, o Partido Social Democrático, o qual se notabilizava nacionalmente pela moderação de suas propostas e por um posicionamento de centro, trazia impressa na fisionomia política de seu candidato a marca do comprometimento com o reformismo econômico-social e abertura às demandas populares do ex-ministro do trabalho de Getúlio Vargas. De imediato, pode-se perceber que o descolamento destas duas formações partidárias em relação às suas matrizes nacionais augurava a possibilidade de problemas no relacionamento bifrontal que qualquer um dos candidatos eleitos haveria de manter, por um lado com o governo da república, por outro com suas bases eleitorais. (FERREIRA, 2004)

Em outra perspectiva está a polivalência de atuação da própria UDN nos termos analisados por Maria Vitória Benevides. Um grande partido nacional sujeito a fragorosas derrotas eleitorais em busca, de formas pragmáticas, de alcançar o poder. Com isso se percebe que candidatos e partidos, visando o poder, formam coligaçōes aparentemente contraditórias, contudo havia uma conexão ideológica que sugere convergências na plataforma política dos envolvidos. Um dos pontos cruciais desse ideário conservador foi o anticomunismo. Desse modo e por essas razôes, a Câmara Municipal possuía esse formato que possibilitou à UDN e ao PTB se unirem contra o prefeito do PSD e seus representantes naquela casa e se integrarem à reação contra a política de reformas do governo de João Goulart.

Pedral era um prefeito duplamente estimulado porque, ao mesmo tempo em que a cidade crescia vertiginosamente e se urbanizava cada vez mais, sus-

\footnotetext{
${ }^{15}$ Integravam esta aliança ainda dois partidos menores: o Partido Republicano (PR) e o Partido Libertador (PL), ambos surgidos do seio da própria UDN.
} 
tentada por um comércio dinâmico e impulsionado por sua vocação de entreposto comercial, surgiam desafios enormes para o gestor municipal, especialmente, devido à falta de estrutura para absorver esse crescimento e reparar as sequelas decorrentes da seca e das frequentes enchentes.

Nesse ambiente, a política conservadora, restrita e enclausurada no suporte econômico fundiário e clientelista estava ultrapassada por uma população experiente cada vez mais ciosa de seus direitos e renovada por uma juventude com determinação para a mudança. O grupo político liderado por José Pedral Sampaio percebeu que a aproximação com o governo João Goulart resolveria a necessidade de investimentos no setor público possibilitando à cidade adequar-se ao seu crescimento demográfico. Desta forma, encontraria nas reformas de base a fórmula ideal para mudar a política sem abalar as estruturas do capitalismo ao qual se integravam boa parte de seus eleitores e apoiadores.

\section{Conclusão}

A experiência da interiorização da repressão após o golpe de 1964 na cidade de Vitória da Conquista, embora com suas especificidades, não difere muito do que ocorreu em outros municípios. A cassação do prefeito José Fernandes Pedral Sampaio e dos vereadores de sua base política foi uma reação de uma parte da elite conquistense derrotada nas eleições de 1962. Todavia, as arbitrariedades notadas no contexto de 1964 não são reflexos apenas da política miúda. Elas incorporam os temas da grande política como desenvolvimento e anticomunismo, considerados fundamentais para a deposição do presidente João Goulart.

As intenções das reformas de base eram modificar o modelo capitalista já bastante obsoleto que emperrava o desenvolvimento industrial do país e integrálo a uma economia mais flexível sem remover as suas estruturas. Ocorre que Jango, após o plebiscito, para viabilizar politicamente essas reformas que garantiriam a sua governabilidade, apoiou-se num arco de alianças muito diversificado e propenso a radicalizaçóes de seu projeto de reformas ou à sua completa absorção pelo modelo conservador vigente.

Por outro lado, na oposição, estavam vigilantes os precursores de uma outra proposta que supunham a necessidade de conservação das bases políticas naquele mesmo estágio, contudo vislumbravam a necessidade de avançar no desenvolvimento industrializado e na inserção do país no capitalismo internacional. O espectro do comunismo era a grande ameaça a esse projeto de Brasil 
e, em certo momento, pareceu aos interlocutores dessa proposta que João Goulart perdera o controle sobre as amplas bases políticas que apoiavam.

Assim, anticomunismo e desenvolvimento nacional passaram a ser elementos do contraditório e avançaram aceleradamente para a ordem do dia em todos os cantos do Brasil. A associação entre os temas políticos e as querelas locais foi o mote da interiorização da repressão em Vitória da Conquista e explica, em parte, o comportamento, por vezes antagônico, das elites locais.

A narrativa dessa experiência é uma tentativa modesta de compor os demais estudos sobre o golpe de 1964 na Bahia, um panorama geral dessa situação e descentralizar o foco das atenções sobre tão intenso momento da política nacional.

\section{REFERÊNCIAS}

FERREIRA, Muniz. G. O Golpe de Estado de 1964 na Bahia. Salvador, 2004. Apresentação de Trabalho. (Inédito).

FONSECA, Humberto José. Formação política da região sudoeste da Bahia. In:

AGUIAR, Ednalva Padre et al. Política: o poder em disputa: Vitória da Conquista e região. Vitória da Conquista: UESB, 1999. (Série Memória Conquistense, n. 4).

IVO, Isnara Pereira. O anjo da morte contra o Santo Lenho: poder, vingança e cotidiano no sertão da Bahia. Vitória da Conquista: UESB, 2004.

Poder local e mandonismo na cidade da Conquista: violência e administração pública. In: AGUIAR, Ednalva Padre et al. Política: o poder em disputa: Vitória da Conquista e região. Vitória da Conquista: UESB, 1999. (Série Memória Conquistense, n. 4).

MEDEIROS, Ruy. Há 35 anos, um desesperado maio. Jornal da Semana, p. 14, 7 de maio de 1999.

SAMPAIO, José Pedral. Oficina de Notícias. Jornal-Laboratório do Curso de Comunicação Sócia, Vitória da Conquista, Ba: UESB, v. 8, n. 19, p. 12, jun. 2008. Entrevista concedida à Thaiane Firmino.

SOUSA, Maria Aparecida Silva de. A Conquista do Sertão da ressaca: povoamento e posse no interior da Bahia. Vitória da Conquista, Edições UESB, 2001.

SOUZA, Belarmino de Jesus. Uma leitura da vida política em Conquista na Primeira República. In: AGUIAR, Ednalva Padre et al. Política: o poder em disputa: Vitória da Conquista e regiāo. Vitória da Conquista: UESB, 1999. (Série Memória Conquistense, n. 4). 


\section{5 \\ Salvador em 1968: um breve repertório de lutas estudantis universitárias}

Antonio Mauricio Freitas Brito ${ }^{1}$

No início do ano letivo de 1968, levando uma carroça puxada pelos calouros, estudantes de Economia da Universidade Federal da Bahia (UFBA) interromperam o tráfego no centro de Salvador. Queriam dar visibilidade ao trote. Atividade presente na cultura universitária, o trote era uma maneira dos alunos antigos - veteranos - acolherem a chegada daqueles recém aprovados no vestibular - os chamados calouros. Junto à comemoração da entrada de novos colegas no curso, os jovens também queriam protestar. O conteúdo das críticas pode ser percebido pelos dizeres de um dos irônicos cartazes: 'Quem nasce no Vietnã - Vietnamita. Quem morre - americano'. ${ }^{2}$

Além do trote, no caso da UFBA, o Diretório Central dos Estudantes (DCE) e a União dos Estudantes da Bahia (UEB) chegariam a lançar uma apostila com um histórico da Guerra do Vietnã e sua importância política, concluindo que "a nossa solidariedade a este heróico povo comprova o nosso

\footnotetext{
${ }^{1}$ Professor da Universidade do Estado da Bahia (UNEB) - Alagoinhas. Doutor em História Social pela UFBA.

${ }^{2}$ Jornal da Bahia 13 mar. 1968.
} 
repúdio aos intervencionistas e exploradores, que são os mesmos aqui e lá”3. Diversos diretórios realizariam cursos e debates enfocando a questão. Um exestudante membro do Diretório Acadêmico (DA) afirmou que, certa vez, um colega buscou hastear uma bandeira pró-Vietnã na Faculdade de Filosofia. No plano nacional, estudantes cariocas foram processados pela Justiça Militar por terem pichado frases alusivas à guerra: "Viva Vietcong"; "Vietcong aponta o caminho" “. Já na Universidade de Brasília, houve algumas assembleias com a bandeira do Vietnã decorando a mesa, simbolizando e homenageando a resistência anti-imperialista 5 .

Não precisamos de mais exemplos para enfatizar sem meias palavras: a resistência vietnamita constituiu-se numa referência para os estudantes mais engajados no cotidiano do movimento estudantil (ME), sobretudo em 1968. Nesse mesmo ano, diversos países foram sacudidos por manifestações estudantis (MARTINS FILHO, 1996). Para os propósitos deste texto, não nos interessa fazer ampla discussão sobre o tema. Basta ressaltar que "1968 foi um ano de paixões desenfreadas em todo o mundo. Seria difícil inventariar as influências. Mas é possível ressaltar certas linhas de força”. (REIS FILHO, 1998, p. 32)

O trote político anunciado na introdução já demonstra que estas linhas de força impactaram no Brasil não o deixando imune aos terremotos políticos protagonizado por jovens. Em 1968, o golpe de 1964 completava quatro anos. Vivia-se sob a égide de uma ditadura militar e Costa e Silva presidia o país. Setores que tinham apoiado o golpe acreditando que os militares voltariam aos quartéis depois de destituir os civis e os supostos comunistas, já somavam forças junto à oposição. De outro ângulo, após a repressão e envolvida ainda num intenso debate sobre as causas da derrota em 1964 e as perspectivas de luta, a esquerda vivia cisões, rachas, fusões e algumas das suas correntes já vislumbravam ações armadas para enfrentar a ditadura.

Quanto ao movimento estudantil (ME), após ter suas entidades representativas desestruturadas e muitos ativistas destituídos, já atingia outro patamar organizativo a partir de situação ímpar. Aprovada no final de 1964, a Lei Suplicy tornava ilegal a União Nacional dos Estudantes (UNE) e entidades estaduais e visava quebrar a autonomia do ME. Todavia, paradoxalmente, foi fundamental para a reorganização da UNE e dos diretórios acadêmicos, uma

\footnotetext{
${ }^{3}$ Contribuição ao debate sobre o Vietnam. DCE/UEB.

${ }^{4}$ A respeito, ver: Processo Brasil Nunca Mais (BNM) 633, à disposição no Arquivo Edgard Leuenroth (AEL) Universidade Estadual de Campinas.

${ }^{5}$ Ver: Processo BNM 623, à disposição no AEL.
} 
vez que havia setores que eram anti-comunistas, mas defendiam o direito à organização estudantil.

Desse modo, desde 1965 a UNE realizava seus Congressos e, em 1968, a esquerda já havia retomado a direção política da entidade. Para além da esfera organizativa, os anos de 1966 e 1967 foram marcados por lutas estudantis contra a repressão, a política educacional do governo, as anuidades, dentre outros. No caso baiano, estes mesmos anos também foram palco de protestos comuns envolvendo secundaristas e universitários, com destaque para as lutas pela liberdade de expressão e contra a repressão cultural no Colégio Central (1966) e contra a cobrança de mensalidades no ensino secundário em 1967 (BENEVIDES, 1999; BRITO, 2003; DIAS, 2001).

\section{A luta dos excedentes}

A partir desse acúmulo de experiência, o ME deu sinal de vida logo no início do ano com a mobilização dos excedentes. Classificados no vestibular, mas em posição aquém do número de vagas oficialmente declaradas ou abaixo da média necessária, esses estudantes - chamados de excedentes - buscaram desenvolver formas de pressão para garantir sua vaga na universidade.

A questão tinha dimensão nacional sendo interessante frisar que houve lutas de excedentes em diversas universidades. Referenciado principalmente na imprensa, José Alberto Saldanha de Oliveira (1998, p. 150) destaca que a mobilização dos excedentes alagoanos envolveu diversos segmentos da população, desenvolveu várias formas de luta, mas, ao contrário de outros estados, não teve como "objetivo explícito colocar em xeque a política educacional do regime militar". Já no Rio Grande do Norte, por exemplo, houve acampamento em praça pública, abaixo-assinado, pressão junto a parlamentares do estado (SILVA, J., 1989).

No caso da UFBA, essa demanda por vagas no ensino superior também esteve na pauta do ME. O DCE/UEB lançou um Caderno dos Excedentes ${ }^{6}$. Além disso, houve tentativa de organizar a luta, reunindo os DA's e preparando um levantamento de vagas existentes nas unidades. No que pese os esforços, os encaminhamentos não contemplaram o tempo e a dinâmica real da luta em curso, haja vista que, um dia depois da reunião entre as entidades estudantis, os excedentes de arquitetura - através do DA - começaram um acampamento em frente à Reitoria. Aliás, esta iniciativa seria alvo de críticas por parte

${ }^{6}$ Caderno de Excedentes. DCE/UEB. Gestão 67/68. 
de diretores do DCE/UEB, na maior parte ligados ao Partido Comunista Brasileiro (PCB). É possível que as divergências tenham se acentuado devido ao fato do presidente do DA ser integrante da Ação Popular - corrente política adversária do PCB.

Mesmo que possa ter existido disputa pela direção política da mobilização, os estudantes de arquitetura estavam em um nível de organização adiantado. O DA já tinha conquistado o apoio dos professores, da Congregação e o Diretor da Faculdade teria viajado à Guanabara com o intuito de solicitar verbas suplementares ao Ministério da Educação e Cultura (MEC) para efetivar a matrícula dos excedentes.

Embalados ao som do violão e portando faixas com os dizeres "Se o país precisa de arquitetos, por que somos excedentes?”, os estudantes nutriam esperança de que dessa viagem resultasse a ampliação de vagas. A realização do acampamento em frente à Reitoria pode ter tido o objetivo de pressionar o Reitor Roberto Santos a assumir a liderança institucional da luta. Depois de sete dias acampados, manifestaram alegria quando lhes anunciaram que seriam matriculados. Levantaram o acampamento prometendo voltar, caso a promessa não fosse cumprida ${ }^{7}$.

Longe de ser um problema restrito à Arquitetura, esta questão perpassou diversas áreas. Apesar das iniciativas organizativas já apontadas, não houve muita unificação entre os cursos. A fragmentação reproduzia-se porque esta reivindicação encontraria desfecho nas Congregaçôes de cada curso ou Faculdade - ainda que na maior parte dos casos dependesse de verbas federais.

Quanto às formas de luta, em geral, as soluçôes negociadas com as diversas Congregações foram privilegiadas. Essa tática deu certo na maioria dos cursos/Faculdades onde identificamos registros desta mobilização, quais sejam, Odontologia, Ciências Econômicas, Farmácia, Direito, Faculdade de Filosofia, Medicina e Arquitetura. Em relação ao silêncio quanto aos outros cursos, há duas ideias complementares. É possível ter ocorrido alguma manifestação de excedentes sem visibilidade política e pública. Uma segunda é lembrar que o problema não emergia em todas Faculdades já que alguns cursos - a exemplo de Ciências - tinham baixa concorrência e/ou sobravam vagas por faltarem candidatos.

Ainda discorrendo sobre a tática, parece que houve uma síntese de vontades entre estudantes, professores e Diretores. Além disso, o MEC prometeu verbas suplementares para atender à demanda ao mesmo tempo em que uma

${ }^{7}$ Jornal da Bahia 14 mar. 1968. 
comissão criada pelo governo para elaborar a reforma da universidade - sem a participação estudantil - propunha mudanças no vestibular para esvaziar a questão dos excedentes. De todo modo, para comemoração dos estudantes baianos, na maior parte dos casos, os excedentes foram matriculados ${ }^{8}$. Vale enunciar que isso se constituiu num paradoxo: ao mesmo tempo em que os estudantes eram matriculados, o governo cortava verbas para as universidades. Como demonstraremos adiante, as consequências desse problema para a UFBA viriam à tona...

Sem sucesso na unificação da luta e por vezes com disputas internas, a UEB/DCE tentaram ser o elo entre os excedentes de diferentes cursos. É bem provável que as lideranças do $\mathrm{ME}$ tenham formulado a respeito da importância da luta, seja no sentido de democratizar o acesso à universidade, seja para fortalecer o ME estreitando laços com os novos alunos. Além disso, tornava-se fundamental aproveitar o suposto ímpeto dos calouros para o engajamento no $\mathrm{ME}$ como se depreende da leitura do Caderno da UEB/DCE, no qual as lutas dos excedentes "servem como meio de educação e de preparação àqueles que serão os futuros universitários e substitutos das atuais lideranças”. É neste sentido que se discutiu também a Semana do Calouro - prevista para ter início em $1^{\circ}$ de maio.

\section{A morte de Edson Luís e a reação do ME na UFBA}

Os planos teriam que ser mudados por um acontecimento inesperado. Em 28 de março, estudantes cariocas protestavam contra o fechamento do Restaurante Calabouço. Houve atritos com a chegada de policiais. Tiros foram disparados sendo que um deles alvejou o jovem estudante Edson Luís que caiu morto na calçada. Os estudantes resolveram não liberar o corpo para as autoridades, pois temiam que a Polícia desaparecesse com o cadáver. Levaram para a Assembleia Legislativa do Estado. (VALLE, 1999)

A resposta ao brutal assassinato viria dias depois em escala nacional. Houve comoção na opinião pública e passeatas de protesto em diversas cidades (MARTINS FILHO, 1987). Estes ventos de indignação com a repressão policial também sopraram na UFBA. Em 30/03, o DCE e a UEB deflagraram greve geral de protesto contra o assassinato do estudante. Programaram uma concentração na Praça Castro Alves e uma passeata com bandeira de luto pelo centro da cidade.

\footnotetext{
${ }^{8}$ A única informação que relativiza essa interpretação diz respeito a uma greve de estudantes de Geologia protestando contra a não matrícula de alguns excedentes no curso.
} 
O governador Luís Viana lamentou a morte do jovem ao mesmo tempo em que fez pronunciamento pela TV pedindo aos estudantes para não irem às ruas "perturbar a vida da cidade". Além dessa iniciativa, o governo tentaria esvaziar a reação estudantil fechando as escolas públicas.

Houve reuniōes nas Faculdades e passeata silenciosa rumo ao Restaurante Universitário para nova assembleia. Aprovou-se uma Missa de $7^{\circ}$ dia pela memória de Edson Luís. Celebrada no Mosteiro de São Bento e com as palavras religiosas proferidas pelo Abade D. Timóteo, a atividade contou com quase 1.500 presentes, entre estudantes, artistas, intelectuais e outros setores sociais ${ }^{9}$. Esta composição por si só denota que o protesto não ficou restrito ao $\mathrm{ME}$.

No outro dia, os estudantes realizaram um Comício no centro da cidade com direito à farta distribuição de panfletos e manifestos à população sobre as razões do protesto. Organizaram comícios-relâmpago em pontos de ônibus. Alguns chegaram a entrar nos veículos e proferir discursos buscando angariar o apoio da população. Até pichação foi feita pelas ruas do centro. A passeata continha cartazes com vários dizeres, entre os quais: "Abaixo a violência", "Abaixo o arrocho", "Queremos escola e comida para o povo" ${ }^{10}$. Estas formas de comunicação e o conteúdo das mensagens revelam uma tentativa do ME buscar sensibilizar a população para a luta contra a ditadura.

Antes da passeata, os estudantes aprovaram em assembleia geral batizar o viaduto do Canela com o nome de Edson Luís e também colocar uma placa no Restaurante Universitário, em homenagem ao estudante assassinado. Encerrando a semana de protesto, decidiram voltar às aulas após suspender oficialmente a greve geral. Como parte de uma estratégia de acumular força e aprofundar o debate em torno da política educacional do governo, os primeiros dias de aula foram destinados a organizar a Semana do Calouro.

Quanto ao balanço dos protestos, em sintonia com o que ocorria em outros estados, a mobilização ganhou altos níveis de apoio de setores sociais. Segundo uma autora, foi a principal vitória do ME junto a opinião pública (VALLE, 1999). Artistas de teatro reverteram para os estudantes a renda da peça 'Uma Obra do Governo', em cartaz no Teatro Vila Velha. Intelectuais publicaram manifesto criticando a violência policial e solidarizando-se com os estudantes. Houve uma passeata que foi considerada uma das maiores realizadas pelo ME - avaliação semelhante ao que ocorreu noutras cidades, como o Rio de Janeiro. (DIRCEU; PALMEIRA, 1998)

\footnotetext{
9 Jornal da Bahia 4 abr. 1968.

${ }^{10}$ Jornal da Bahia 5 abr. 1968.
} 


\section{A greve dos estudantes da UFBA}

Se em escala nacional, a morte de Edson Luís teve papel fundamental para colocar em voga a luta anti-ditatorial, logo em seguida ocorreria uma mudança: o central da pauta do ME seria a política educacional do governo. Em comum acordo com essa agenda nacional, um dos principais acontecimentos do ME da UFBA foi a greve contra o corte de verbas para a instituição.

Esse problema era antigo. Ao observar as Atas do Conselho Universitário, percebemos que, desde 1965, havia queixas em relação ao orçamento. Em 1965, houve uma redução de 20\%; em 1966, baixou 33\%; em 1967, foi dito que não estaria em condições satisfatórias ${ }^{11}$. Já em março de 1968, o corte de verbas e suas consequências para o funcionamento da universidade foram publicizados $^{12}$. Nessa época, mais da metade do orçamento era comprometida com o pagamento de pessoal e a parte de custeio seria a principal atingida. Para piorar a situação, mesmo com o corte, as verbas não tinham sido liberadas.

Os estudantes foram às ruas protestar. Através de campanha com comícios relâmpagos e panfletagens, conclamavam o povo a participar da mobilização. O ME teria como estratégia buscar outros setores sociais como aliados e aproveitar espaços de denúncia da crise universitária. Deste modo, confirmaram presença junto à bancada oposicionista do Movimento Democrático Brasileiro (MDB) para participar do $1^{\circ}$ de maio.

Contudo, a mobilização central se deu no nível interno, a partir de cada unidade. A programação da Semana do Calouro - anteriormente suspensa por conta da morte de Edson Luís - foi repensada e colocada em prática. O evento tematizou a política educacional e econômico-financeira do governo ${ }^{13}$. Quanto aos objetivos, a Semana do Calouro visava esclarecer o estudante recém-ingresso na universidade sobre a situação da instituição, o papel do ME e as perspectivas profissionais das áreas específicas. Além disso, esta atividade era compreendida pelo DCE como uma forma de estimular a participação dos calouros.

Já no início de maio, houve uma passeata para protestar contra o corte de verbas e o arrocho salarial. Cerca de mil estudantes participaram da mobilização. Pelas lentes da imprensa, o objetivo central foi desgastar o governo, haja vista os gritos de que "povo organizado derruba a ditadura". A polícia não reprimiu a manifestação.

\footnotetext{
${ }^{11}$ ATA CONSUNI. 23 fev. 1965, 26 ago. 1966 e 2 dez. 1966.

${ }^{12}$ Jornal da Bahia. 17-18 mar. 1968.

${ }^{13}$ Jornal da Bahia. 14-15 abr. 1968.
} 
Talvez percebendo que naquele momento haveria pouca disposição da maioria dos universitários para a luta, o ME seguiu a orientação nacional da UNE de volta às escolas (MARTINS FILHO, 1987). Decidiu fazer discussóes em todas as escolas através de palestras, seminários e constituição de Grupos de Trabalho por Faculdade para um Dossiê/Relatório sobre cada unidade. Uma outra atividade ocorreu dentro desta ótica: o Seminário de Política Educacional do Governo. Na pauta, a preocupação em "estudar, analisar e debater os problemas que afligem a Universidade no Brasil, e principalmente definir e sistematizar uma linha de ação prática para as lutas que teremos de travar contra a política educacional do Governo" ${ }^{14}$. Diga-se de passagem, a greve estava sendo preparada:

A deflagração da greve está sendo adiada porque, segundo as lideranças estudantis, nem todos os universitários estão mobilizados, embora a crise da universidade já se tenha alastrado para quase todas as unidades, em conseqüências dos cortes de verbas imposto pelo governo ${ }^{15}$.

Embora a avaliação acima descrita prime pela preocupação com a mobilização, como foi frisado, os reflexos do corte de verbas já se faziam sentir em todas unidades, somados a reivindicações específicas. Ainda que o DCE/ UEB tenha programado iniciativas para organizar a tomada de deliberação coletiva, neste período, estudantes de dois cursos entraram em greve: geologia e nutrição. Enquanto os primeiros reivindicavam a regulamentação da profissão de geólogo, os acadêmicos de nutrição lutavam por um prédio para desenvolver suas atividades de ensino-aprendizagem.

As entidades estudantis marcaram uma assembleia geral com vistas a aprovar uma resolução coletiva. No entanto, nem todos os cursos esperaram essa reunião e a entrada na greve ocorreu em ritmos distintos - sendo que os acadêmicos de odontologia, medicina e enfermagem iniciaram a greve antes da assembleia geral ${ }^{16}$. Enquanto isso, outras Faculdades aderiam à mobilização. Em 11/06/1968, oficializou-se a greve dos estudantes da UFBA reivindicando a liberação das verbas para a universidade. Segundo um panfleto destinado "ao povo e aos trabalhadores da Bahia”, os estudantes

\footnotetext{
${ }^{14}$ UEB/DCE. I Seminário de Política Educacional do Governo - SEPEG.

${ }^{15}$ Jornal da Bahia 5 jun. 1968.

${ }^{16}$ Enquanto os alunos de odontologia deliberam no dia 06/06, posteriormente, em $07 / 06$, medicina e enfermagem aprovaram greve.
} 
estão [...] em greve contra o corte de verbas destinadas à educação feito pela ditadura reacionária entreguista à qual continua a impor ao povo brasileiro o caminho da fome, da miséria e da opressão. O que atualmente ocorre na Universidade - o corte de verbas - tem como único objetivo a transformação do ensino gratuito em ensino pago, que tornará o mesmo mais distante dos trabalhadores ${ }^{17}$.

No quesito formas de luta, a novidade foi greve de ocupação. Diversas Comissões foram constituídas: alojamento, alimentação, segurança, imprensa etc. Por fim, deliberou-se a necessidade de elaborar relatórios a partir dos problemas específicos, o que implica dizer que as pautas eram diversificadas.

Não detalharemos as reivindicações por curso uma vez que a leitura tornar-se-ia cansativa. $\mathrm{O}$ mais importante é atentar para duas questões. A primeira diz respeito a uma vazão de agendas reivindicatórias, transcendendo a luta por mais verbas. Este aspecto é importante porque denota a estratégia de mobilização estudantil com base no particular. Segundo o presidente da entidade,

quando a luta se desenvolve neste nível, se consegue muito maior participação e também faz com que os estudantes - mobilizados em torno de suas questôes próprias, de seus problemas imediatos - venham entender a verdadeira causa do caos universitário, passando a ver a universidade inserida num sistema econômico e numa estrutura social, que de fato são os determinantes da situação em que nos encontramos ${ }^{18}$.

Ao enfatizar uma pauta marcada por especificidades, os estudantes iriam atingir um outro objetivo: conquistar o apoio dos professores para a greve. É neste sentido que muitos docentes comprometer-se-iam em não realizar exames neste período nem anotar o assunto como dado. Em algumas unidades, teriam presença ativa junto ao corpo discente debatendo os problemas dos cursos. Além disso, declarariam apoio aos estudantes através de Manifestos públicos, como o abaixo reproduzido:

\footnotetext{
${ }^{17}$ ANEXO BNM 8160.

${ }^{18}$ Jornal da Bahia. 6 jun. 1968.
} 
Os abaixo-assinados, professores da Faculdade de Filosofia da Universidade Federal da Bahia, vêm demonstrar, nos termos de seus colegas da Faculdade de Ciências Econômicas da UFBA, a sua desaprovação à política educacional que, aumentando vagas nos cursos universitários e encorajando matrículas de excedentes como medida indispensável ao desenvolvimento, simultaneamente corta as verbas das Universidades reduzindo-as à indigência. Tal demonstração de incoerência e falta de racionalidade se evidencia, ainda, numa reforma universitária que, se apresenta um avanço na sua estrutura orgânica, esquece os estímulos à atividade do docente, de quem muito exige e a quem pouco se oferece, para realização das tarefas de pesquisa e ensino, tão importantes para a comunidade. $\mathrm{Na}$ qualidade de mestres, compreendem as inquietações da juventude como reflexo das incoerências acima denunciadas [no] espírito das massas estudantis.

Salvador, 14 de junho de $1968 .^{19}$

Mas a repercussão da greve não gestou apenas atos de solidariedade ao ME. Exemplo que conforma essa assertiva diz respeito a uma bomba que foi jogada de madrugada na Reitoria da UFBA. A autoria desse ato é desconhecida. Sabe-se apenas que partiu de pessoas mascaradas que fugiram em seguida. Horas depois, provavelmente o mesmo grupo teria invadido a Escola de $\mathrm{Nu}$ trição arrancando cartazes e faixas alusivas à greve, mas teriam sido afugentados por membros da Comissão de Segurança que pernoitavam no estabelecimento $^{20}$.

O exemplo citado permite atentar para o papel da Comissão de Segurança. Sua atribuição era não permitir que pessoas estranhas entrassem nas Faculdades com o objetivo de promover vandalismo e descaracterizar as lutas estratégia usada pela polícia que buscava infiltrar membros dos seus efetivos seja para fins de espionagem, seja para promover atos inconsequentes. Longe de ação isolada da polícia local, ela era parte do modus operandi nacional do aparelho repressivo. Segundo Wladimir Palmeira, houve infiltração de agentes do Departamento de Ordem Política e Social (DOPS) na comissão de segu-

\footnotetext{
${ }^{19}$ A Tarde 15 jun. 1968. A iniciativa do Manifesto partiu dos professores da Faculdade de Ciências Econômicas. Foi subscrito também por docentes das Faculdades de Direito e Arquitetura.

${ }^{20}$ A Tarde 14 jun. 1968.
} 
rança carioca (DIRCEU; PALMEIRA, 1998, p. 131). Este depoimento reforça, em alguma medida, a entrevista de militares acerca da eficácia dessa estratégia. O Tenente-Coronel Adyr Fiúza de Castro chegou a afirmar que mais da metade da Comissão de Segurança na Passeata dos Cem Mil era constituída de Sargentos do Exército (D’ARAÚJO, et al., 1994b, p. 40).

Outras comissões também tinham papel importante. A de imprensa destacava-se por dialogar com amplas parcelas da sociedade. Os principais meios eram panfletos distribuídos em bairros, pontos de ônibus, jogos de futebol, ônibus. Usava-se também o Jornal-Mural - meio de comunicação bastante utilizado desde tempos anteriores pelo ME. Em termos de sonorização, lançava-se mão de alto-falante colocado na frente das Faculdades onde estudantes revezavam-se na tarefa de esclarecer a população sobre as razões da luta.

Essa política de comunicação articulava-se com a financeira. Buscando viabilizar fundo de greve para eventuais despesas, o ME organizava os pedágios. Eram grupos de estudantes solicitando aos pedestres e, sobretudo aos motoristas, ajuda material para a greve. Uma outra forma de arrecadação era a contribuição dos professores. Por último, a Comissão de Alimentação estava afinada com as outras, construindo campanhas de arrecadação de alimentos organizadas junto à sociedade. Estas ações nos mostram a preocupação do ME em diversificar as formas de luta buscando ganhar apoio social.

Interessante notar que a força do movimento grevista influenciou também estudantes de outras instituições. Deste modo, alunos da Escola Baiana de Medicina e da Universidade Católica também deflagraram greve de ocupação. As reivindicaçôes básicas eram contra a cobrança abusiva de anuidades e a favor do ensino de qualidade. Os ventos da greve chegaram também aos secundaristas. Com demandas específicas, a exemplo da crítica ao vestibular único - segundo as entidades, dificultaria mais ainda o ingresso das camadas populares na Universidade ", o ME secundarista dava passos na mobilização que poderia desembocar numa greve no setor.

\section{A polícia invade as faculdades}

Depois de alguns dias ocupando as faculdades, na madrugada de 15/06 os universitários foram surpreendidos com a invasão de tropas da Polícia Militar, Corpo de Bombeiros e de agentes do DOPS que, armados e levando cachorros amestrados, prenderam os estudantes que lá se encontravam. 
De todas unidades da UFBA, a Faculdade de Medicina foi a última a ser invadida e a mais agredida. Segundo um jornal, "tropas da polícia utilizando uma escada do corpo de bombeiros, penetraram pela porta da frente, quebrando ainda duas janelas laterais com coronhadas de rifle". O DA elaborou um relatório onde constava que a polícia "consumou o mais lamentável ato de vandalismo, pilhagem e estupidez que a Faculdade foi alvo durante seus 160 anos de autonomia" ${ }^{21}$. Segundo os estudantes, entre os danos causados pela polícia, encontravam-se: arrombamento e destruição parcial do gabinete do Diretor e das salas de Congregação, da Secretaria, do Conselho Departamental e do DA, destruição da porta do salão nobre, das máquinas de escrever, telefones e material literário, desaparecimento de alimentos destinados aos estudantes que se encontravam no local.

Mesmo a ação policial não implicou fim da greve. Um dia após o incidente, os alunos voltaram para as faculdades afixando cartazes para denunciar a invasão. Paralelo a isto, professores de diversas unidades universitárias reuniram-se na Reitoria para analisar os acontecimentos da madrugada, deixando explícito:

a) seu inconformismo em face do desrespeito à autonomia universitária e à autoridade de seus dirigentes; b) sua solidariedade às providências adotadas pelos órgãos diretivos da universidade e c) sua disposição de dar continuidade ao diálogo com o corpo discente, buscando uma solução em comum para os graves problemas que afligem a universidade brasileira ${ }^{22}$.

O Reitor Roberto Santos manifestou-se contra a invasão das faculdades pela polícia, alegando que a universidade era regida por um regime disciplinar próprio e que seus problemas eram exclusivamente afetados por esse sistema. Em seguida, recebeu uma comissão de 15 estudantes. Do ponto de vista público, a direção da universidade se posicionou:

As autoridades universitárias, reunidas para exame da situação em que se encontra a Universidade Federal da Bahia e preocupadas com o seu desdobramento, dirigem aos estudantes veemente apelo para que retomem suas atividades, a fim de que o diálogo entre professores e alunos

\footnotetext{
${ }^{21}$ Jornal da Bahia 16 jun. 1968.

${ }^{22}$ Jornal da Bahia, 22 jun. 1968.
} 
em torno dos problemas universitários continue no exclusivo âmbito em que se deve manter, recomendar-lhes vigilância para que se não desvirtuem sua motivação e sentido originários ${ }^{23}$.

Os estudantes continuaram na luta. No dia 26/06/1968, em assembleia realizada na Faculdade de Filosofia, decidiram manter a ocupação das Faculdades, o funcionamento das comissões de esclarecimento popular, bem como comícios-relâmpago em diversos bairros de Salvador.

Enquanto resultado da mobilização, quase dois bilhões de cruzeiros foram liberados pelo Governo para a UFBA. Ainda assim, e evidenciando que a luta não era apenas por mais verbas, os universitários confirmaram passeata contra a política educacional do governo. Com expectativa de contar com a presença de professores, intelectuais, artistas, jornalistas e clero, os estudantes intensificaram a campanha de esclarecimento popular.

A ordem lida nas assembleias sugeria que os discentes enviassem as reivindicações ao DCE, com cópia aos diretores que as encaminhariam ao Reitor. Além disto, orientava que os estudantes discutissem a validade da ocupação das escolas nas salas de aula, distribuíssem questionários à população e continuassem buscando o comprometimento dos professores com o movimento. Em termos de perspectivas, propunham que a greve continuasse " mesmo com a liberação das verbas - caso outras universidades brasileiras entrassem em gre$\mathrm{ve}^{24}$.

Dias depois, os estudantes voltaram às ruas com o apoio de jornalistas e intelectuais. Saindo de três roteiros diferentes, protestaram contra a repressão policial, a política educacional do governo e o arrocho salarial. Jornalistas aderiram ao movimento. Intelectuais baianos também estiveram presentes na passeata com a faixa "Jovens poetas da Bahia com os estudantes". Depois de ocuparem as ruas, os estudantes decidiram manter a greve e enviar um Memorial ao Reitor contendo as reivindicações específicas.

Enquanto isso, os professores universitários se mobilizavam para construir a Associação da categoria:

\footnotetext{
${ }^{23}$ A Tarde, 22 jun. 1968.

${ }^{24}$ É importante dizer que a redução de verbas foi um problema de ordem nacional. Segundo Florestan Fernandes (1979, p. 53) "as universidades federais receberam cortes que reduziram seus orçamentos em 37\%". Isso gerou mobilizaçōes sendo que na Universidade Federal do Rio de Janeiro (UFRJ) houve greve por tempo determinado (MARTINS FILHO, 1987). Neste sentido, é possível que os estudantes baianos tivessem alguma expectativa de uma greve nacional contra o corte de verbas.
} 
'Neste momento de crise, devemos estar unidos em torno de órgão independente que possa congregar os corpos docentes de todos os níveis e de todas as categorias', explicaram os professores Istvan Jancsó e Renato Mesquita, à frente do grupo da Faculdade de Filosofia que tomou a iniciativa ${ }^{25}$.

Marcaram uma assembleia para o dia 04/07/1968. Desnecessário dizer que o ME deve ter influenciado muitos dos professores na perspectiva de uma organização sindical.

\section{A ação no escritório do MEC-USAID}

Como já foi dito, a greve tinha pautas específicas e gerais. Dentre elas, estava a crítica aos Acordos MEC-USAID ${ }^{26}$. Numa das passeatas, depois de percorrerem as ruas do centro e realizarem um Comício no Campo Grande, um grupo de manifestantes ocupou o escritório da MEC-USAID que funcionava próximo à Reitoria. Os dirigentes da UEB e DCE tinham posição divergente.

Parece que o outro grupo de estudantes tinha disposição de incendiar o local, simbolizando a revolta dos estudantes face ao Acordo. $O$ fato é que houve uma ocupação do escritório, quebra-quebra e incêndio de parte das instalaçôes. No final do ato, Hermínio Vieira, um jovem sapateiro - sequer era estudante - foi preso e autuado para ser processado pela justiça militar ${ }^{27}$.

No outro dia, as manchetes da imprensa noticiavam o ato como uma coisa isolada e impensada de uma minoria. Dias depois, o governo emitiria comunicado oficial afirmando que "não mais serão permitidas passeatas ou concentrações de qualquer natureza"28. Longe de ser uma mera formalidade,

\footnotetext{
${ }^{25}$ Jornal da Bahia, 29 jun. 1968.

${ }^{26}$ USAID é a abreviatura de United States Agency for International Development. Segundo Martins Filho (1987, p. 130), "os acordos MEC-USAID inseriam-se numa longa tradição de 'colaboração técnica' entre o Brasil e os Estados Unidos da América, que remonta ao pós-45. Até 1956, no entanto, os convênios assinados se restringiram ao fornecimento de assessoria e equipamentos no setor do ensino técnico. No Governo Kubitschek, a influência americana ampliou-se a projetos no ensino elementar. Na década de sessenta, após a vitória da Revolução Cubana, o Departamento de Estado dos EUA mostrou renovado interesse em implementar acordos mais abrangentes. Entretanto, a crise do Governo Goulart fez com que, mesmo assinados, esses convênios permanecessem letra morta. Com o golpe de 64, a situação alterou-se significativamente e logo se retomaram os entendimentos com a USAID. A série de acordos assinados entre 1964 e 1966 é que passou a ser conhecida como os Acordos MEC -USAID”.

${ }^{27}$ BNM 49.

${ }^{28}$ A Tarde, 8/ jul. 1968.
} 
esta declaração adquiriu sentido prático nas próximas ações de rua desenvolvidas pelo $\mathrm{ME}$, conforme veremos. Sobre a ação em si, não encontramos nenhum registro a favor da iniciativa. Em sentido contrário, as entidades estudantis lançaram nota oficial criticando o fato ${ }^{29}$.

Este episódio indica divergências no interior do ME, sobretudo entre as correntes políticas. Vale sublinhar que o debate sobre este episódio não ficou restrito às lideranças das entidades e/ou das correntes políticas. Exemplo que confirma essa reflexão diz respeito a uma resolução tirada numa assembleia dos alunos de Física e Matemática:

Assim é que, junto às chamas da bandeira dos Estados Unidos, uma pequena parcela que quebrou e queimou o MEC-USAID, foram esgotados toda a revolta e potencial da luta de massa, transformando-os automaticamente numa auto-satisfação primitiva e deplorável. Também fica registrada a tentativa de levar uma passeata, que não era somente estudantil, para a frente da Reitoria Isto é oportunismo! Conscientemente ou inconscientemente se tentou utilizar trabalhadores mobilizados em torno da luta contra o 'arrocho salarial' e a "ditadura" para a obtenção pura e simples das reivindicaçóes estudantis ${ }^{30}$.

\section{A luta reivindicatória}

Aplicando uma resolução já mencionada em linhas anteriores, o ME da UFBA passou a priorizar reivindicações específicas. Os relatórios construídos nas unidades seriam sistematizados num documento único: o Memorial. Em 10/07/1968, após uma assembleia realizada na Escola de Teatro, cerca de 1500 estudantes foram a um encontro com o Reitor Roberto Santos e entregaramlhe o Memorial $^{31}$ com um prazo de 10 dias para a Reitoria se posicionar em relação ao conteúdo das reivindicações. No mais, aprovaram a criação de uma Comissão Mista entre Professores e Estudantes para apreciar as reivindicações. Isso tinha uma lógica, notadamente porque havia reivindicações que dependiam de verbas do governo federal; outras seriam negociadas com o Reitor; e outras ainda poderiam ser resolvidas em cada Faculdade.

\footnotetext{
${ }^{29}$ A Tarde, 6 jul. 1968.

${ }^{30}$ A Tarde, 18 jul. 1968. Não encontramos documentação nem entrevistas com argumentos a favor da iniciativa.

${ }^{31}$ A Tarde, 10 jul. 1968.
} 
É possível imaginar a existência de um desgaste político no ME já que os estudantes ultrapassavam a marca dos 30 dias em greve. Mesmo a ocupação, já era mantida em esquema de rodízio. Além disso, não esquecer que, quanto mais tempo em greve, mais as férias ficariam comprometidas. Sem falar nos formandos. Motivações à parte, em 25/07 surgiu o debate para finalizar a greve. A proposta foi rejeitada. Mas o principal aspecto a ser enfatizado foi a tentativa imprimida pelo ME de deslocar o eixo da greve para a questão da Reforma da UFBA. Afinal, já havia mais de um mês em greve e pouco debate em relação à Reforma Universitária, em curso adiantado na UFBA.

Talvez em busca de informaçôes e aliados políticos, os estudantes aprovaram a criação de um Fórum de Debates sobre a Reforma da UFBA. A ideia foi incorporar professores do Conselho Universitário, membros da Comissão Mista e todos aqueles que estivessem interessados no tema. Embora tivesse alegado inicialmente que problemas de agenda o impossibilitariam de se fazer presente no debate, o Reitor resistia à discussão do tema com os estudantes. Estes alegavam o pouco esclarecimento e divulgação sobre a reforma em curso; sobre o conteúdo, diziam que as mudanças propostas tinham orientação imperialista. Por sua vez, o Reitor argumentava que a reforma se inspirou no projeto da Universidade de Brasília e que inexistia clima para debater com os estudantes $^{32}$.

Neste cenário, o dia 30/07 foi programado para reuniōes nas unidades. $\mathrm{Na}$ assembleia geral do dia posterior, o ME aprovou a volta às aulas no dia 05/08. Marcou-se a segunda sessão do Fórum de Debates e concluiu-se a reunião com a avaliação de que o retorno às aulas era uma tática para informar e mobilizar mais os alunos. Além disto, diversificando as bandeiras de luta, os estudantes aprovaram a realização de um protesto contra o aumento das tarifas de ônibus.

\section{Agosto: em poucos dias, intensos confrontos}

A volta às aulas foi marcada por indignação com a prisão de Wladimir Palmeira - considerado o mais importante líder estudantil do ME carioca. Explodiram manifestações em algumas cidades. No caso baiano, os estudantes aprovaram fazer uma passeata para criticar a prisão, bem como, protestar contra o aumento do preço da passagem em transportes coletivos e denunciar a política educacional do governo.

\footnotetext{
${ }^{32}$ É lícito mencionar que, desde 1965, nas atas do conselho universitário UFBA, encontramos notas de visitas de "técnicos” estrangeiros, a exemplo de Rudolf Atcon, para “auxílio" na reforma da instituição.
} 
Em 06/08, o que seria uma passeata estudantil transformou-se em conflitos generalizados entre policiais e estudantes. Implementando a resolução expressa no comunicado oficial emitido após o fato relacionado ao escritório MEC-USAID, atendendo à pressão de militares da chamada linha dura no interior do governo estadual, ou sem controle efetivo sobre a esfera repressiva estatal, a atuação da repressão governista foi marcada pela violência. Houve um trabalho de equipe entre Polícia Civil, Polícia Federal, Polícia Militar, DOPS e Guarda Civil.

O resultado foi dezenas de feridos, prisões de estudantes e jornalistas, tiros para o alto, bala perdida atingindo a Assembleia Legislativa e uma bala acertada em Júlio Pavese, aluno do curso de Ciências Sociais. Impactados com a repressão, os jovens se dispersaram e reorganizaram-se na Reitoria e no Restaurante Universitário. Cerca de 100 estudantes fizeram um plantão na Clínica e acompanharam o estado de saúde do colega baleado. Professores de Medicina também prestaram assistência. Houve doação coletiva de sangue para o estudante. Em resumo: a violência da polícia reforçou laços de solidariedade ao ME.

Já a reação estudantil não teria apenas como ingrediente o repúdio à violência. Para se ter uma ideia, ainda na noite do incidente, um grupo de estudantes estava reunido em frente ao restaurante universitário quando notaram um aparente desconhecido, de fisionomia familiar. Alguém percebeu que aquele rosto era mais próximo do que se pensava. $\mathrm{O}$ grupo tomou a iniciativa de chamar estudantes com tradição de participação nas Comissões de Segurança das passeatas. Eis que o desconhecido fora abordado. Tomaram-lhe os documentos e constataram que, conforme suspeitas, tratava-se de um agente do DOPS que supostamente cumpria função de espionagem. Vendaram-lhe os olhos e levaram-no à Assembleia estudantil que, a esta altura, já se desenrolava. A entrada na Reitoria foi um espetáculo. Imaginemos a cena: numa reunião com ânimos à flor da pele, estudantes trazendo como refém um policial amarrado, passivo e inofensivo. Certamente as propostas mais diversas devem ter surgido sobre o que fazer com aquele policial... No final das contas, o deboche foi a tática para desmoralizá-lo. Segundo um ex-estudante de Direito:

Ele estava com a namorada no ponto de ônibus em frente da residência universitária, olhando os estudantes e dando informação. Articulamos e prendemos o cara [que] foi levado para uma assembleia enorme que estava tendo na reitoria [...] com um pano na cabeça. Quando ele chegou foi um impacto violento, todo mundo ficou assombrado 
[...]. Debateu-se na assembleia o que fazer com ele, decidiu levar para a Escola de Veterinária. Naquele tempo ainda não existia o PAF. Tudo ali era uma mata geral, então ele ficou lá a noite toda naquela mata e quando foi uma certa hora da madrugada [...] deixou ele [de cueca] na pista de Ondina lá na praia.

Após essa atitude irônica, o ME marcou nova manifestação de rua a partir de três pontos diferentes. Seu destino era a Praça Municipal - local que concentrava, além da Assembleia Legislativa, a Câmara de Vereadores, Prefeitura Municipal e a sede do Governo Estadual. A polícia não deixou. Tiros e bombas de gás lacrimogêneo foram lançados. Houve espancamento indiscriminado. Populares que se encontravam no centro realizando compras teriam sido agredidos. A polícia teria infiltrado agentes no meio dos estudantes para efetuar provocaçōes ${ }^{33}$. Um Professor Catedrático da Escola de Belas Artes - Riolan Coutinho - que passava por perto foi espancado e jogado em um caminhão com dezenas de mulheres e menores de idade ${ }^{34}$. Alguns estudantes buscaram refúgio no Mosteiro de São Bento. Ao contrário de outras vezes, nesta oportunidade os policiais não respeitaram a Igreja nem tampouco atenderam aos apelos do Abade D. Timóteo Anastácio. Invadiram o templo, espancaram e prenderam alguns estudantes. Sete pessoas foram feridas a bala ${ }^{35}$. Estes dados mostram o quanto o regime militar havia endurecido, desrespeitando leis e instituições (BENEVIDES, 1999).

O dia seguinte caracterizou-se por articulação política para outra passeata anunciada. A invasão do Mosteiro virou alvo de críticas. Sob a presidência de D. Timóteo Anastácio, estudantes, intelectuais, professores e artistas reuniram-se na Escola de Teatro para um Ato político de protesto. Parlamentares do MDB prestaram solidariedade a D. Timóteo. Enquanto isso, nas Faculdades, o clima era de tensão. A Escola de Administração foi invadida pela Polícia e espalharam-se boatos de que outras unidades estariam na mira. Havia desconfiança sobre qualquer pessoa de fisionomia desconhecida, tida como agente policial.

No centro de Salvador, a imprensa noticiou incidentes entre populares e policiais. Em alguma medida, depreende-se da leitura dos jornais a vigência de uma paisagem social de tensão e medo. Esta análise se reforça na medida em

\footnotetext{
${ }^{33}$ A Tarde, 9 ago. 1968.

${ }^{34}$ Jornal da Bahia, 9 ago. 1968.

${ }^{35}$ Jornal da Bahia, 9 ago. 1968.
} 
que encontramos reportagens enfatizando que o comércio estaria sofrendo grande prejuízo, bancos com expedientes encerrados, clientes desmarcando consultas, pontos facultativos em repartições públicas etc. Alegava-se também que o dia do papai teria apresentado queda de vendas em $40 \%{ }^{36}$.

Diante dessa atmosfera, a polícia montou um forte esquema de repressão ostensiva, em meio a boatos de uma nova mobilização. As tropas saíram fortemente armadas. $\mathrm{O}$ centro fechou o comércio. Houve invasão policial nas Faculdades de Administração e Ciências Econômicas. Atentos à correlação de forças sociais, os estudantes não foram às ruas declarando que suspenderam a passeata prevista "para evitar o massacre" ${ }^{37}$.Já em 15/08, a passeata terminou com um jornalista tendo sido agredido pela polícia e 7 estudantes presos ${ }^{38}$. Ademais, não houve nenhum incidente e os estudantes universitários parecem ter organizado um recuo ${ }^{39}$. Como já foi dito, o endurecimento da repressão na Bahia não era algo isolado da situação nacional.

Diante disto, tornava-se fundamental debater a situação do país e os desafios do ME. Para tanto, os estudantes debruçar-se-iam centralmente na preparação local para o 30 Congresso da União Nacional dos Estudantes. Desnecessário dizer que estes confrontos refletir-se-iam em propostas de enfrentamento. Reagindo à conjuntura, o ME radicalizava seu discurso e métodos de ação. Como um demonstrativo dessa radicalização, é importante que apontemos rápidas notas sobre a Faculdade de Direito.

Após reconhecer três membros da polícia que eram estudantes de direito e tinham participado diretamente da repressão ao ME na condição de policiais, os acadêmicos do curso se mobilizaram reivindicando a expulsão daqueles tenentes-estudantes. O clima de hostilidades ficou tão intenso que houve uma determinação por parte do Diretor - Professor Orlando Gomes - no sentido de fechar a Faculdade de Direito. Houve ocupação pelos alunos; desocupação com base em mandato de reintegração de posse, solicitado pelo Diretor; reabertura da Faculdade; fechamento novamente. Essa mobilização deixou a Faculdade sem aulas por quase um semestre. A Congregação da Faculdade criou uma comissão para investigar a questão. No final das contas, os três estudantes permaneceram matriculados na faculdade. Independente do desfecho, este acontecimento ilustra um clima de radicalização no $\mathrm{ME}$, num contexto de

\footnotetext{
${ }^{36}$ A Tarde, 13 ago. 1968

${ }^{37}$ Jornal da Bahia, 14 ago. 1968.

${ }^{38}$ Jornal da Bahia, 16 ago. 1968.

${ }^{39}$ Essa avaliação fundamenta-se no fato de que os secundaristas teriam tido disposição para organizar outra manifestação no Centro, o que ocorreu em 20/08/1968. Os universitários não se dispuseram a participar do ato.
} 
endurecimento do regime. Vale mencionar que essa nuvem antipolicial tentou se espalhar em outras unidades. Segundo um ex-presidente de Diretório Acadêmico, ocorreu movimento em menor escala na Faculdade de Filosofia:

Em determinado momento, descobriu-se que havia colegas que eram policiais. Alguns estudantes vieram me procurar para denunciar aquilo propondo organizar assembleias para expulsá-los da Faculdade. Não concordei com aquilo.

\section{O $30^{\circ}$ Congresso da UNE: preparação e desdobramentos}

O segundo semestre de 1968 é tido por muitos como o início do refluxo do ME brasileiro (REIS FILHO, 1998; OLIVEIRA, 1994). Neste período, diminuíram as manifestações de rua e o ME viveu polêmico debate sobre os desafios da UNE. No plano político-organizativo, emergiu o dilema entre fazer um Congresso aberto ou clandestino. A maioria optou pela segunda alternativa. Essa divergência nacional se deu principalmente no seio das correntes políticas que predominavam na direção da entidade ${ }^{40}$, quais sejam, a Ação Popular (AP), as Dissidências Estudantis do PCB e a Política Operária (POLOP).

Em termos de UFBA, como já foi dito, a partir do final de agosto o ME voltou sua energia para a participação no Congresso. Os diversos DAs elegeram seus representantes/delegados, tanto para o Congresso Nacional da UNE (CONUNE) quanto para o Congresso Regional UNE - uma das fases do evento nacional. O processo eleitoral combinou a realização de assembleias por curso, votação em urna e indicação/aprovação por séries ${ }^{41}$. Foram ao CONUNE, entre delegados e observadores, 39 estudantes da UFBA e 15 estudantes de outras universidades ${ }^{42}$.

\footnotetext{
${ }^{40}$ Note-se que no caso da UFBA, as organizaçóes políticas mais atuantes eram o PCB, a AP, o Partido Comunista do Brasil (PC do B) e a POLOP. Além disto, havia a chamada esquerda independente que fazia alianças pontuais com uma ou outra corrente política. É interessante registrar que o PC do B estaria mais fortalecido em 1968, sobretudo a partir do trabalho político na Faculdade de Direito, onde tinha um grupo de militantes incluindo o Presidente do CARB, Rosalindo Souza. Contudo, dado o limite das fontes, não sabemos como a configuração entre as tendências manifestou-se, seja em termos de influência política na delegação baiana ao Congresso, seja no ME como um todo. Para um panorama sobre a atuação de parte da esquerda baiana inclusive suas ações no ME, ver: Silva (2003) e Santos (2004).

${ }^{41}$ Ver BNM 71.

${ }^{42}$ DEOPS/SP. Relatório Operação Ibiúna XXX Congresso da Extinta UNE. São Paulo. 12 out. 1968. Documentação disponível no AEL
} 
No que diz respeito ao Congresso Regional UNE, ocorreu polêmica acerca da sua instalação enquanto evento aberto ou clandestino. Este dilema resultava das polêmicas nacionais sobre o Congresso da UNE que também dividia as bancadas dos estados presentes ao fórum, a saber, Pernambuco, Alagoas, Sergipe, Paraíba e Bahia (OLIVEIRA, 1994). O desfecho do impasse foi favorável a um Congresso legal. Segundo Sérgio Passarinho - à época presidente da UEB:

Fizemos o Congresso em locais públicos, em salas de faculdades, os estudantes receberam tickets, impressos. Conseguimos até da reitoria o reconhecimento destes tickets como autorização de ingresso nos restaurantes e residências universitários. Alojamos e alimentamos todos os estudantes que vieram para este evento preparatório. (REIS FILHO, 1998, p. 182)

Cumprida essa fase, restaria instalar o $30^{\circ}$ Congresso da UNE em São Paulo, num sítio na cidade de Ibiúna. De acordo com a documentação da justiça militar, os delegados teriam viajado de ônibus; alguns sozinhos e outros acompanhados. Todos tinham senhas diversas, dadas por um desconhecido com sotaque sulista que passou pela universidade ${ }^{43}$.

Apesar desses cuidados, o evento foi desbaratado. Mostrando como o aparelho repressivo se organizava nacionalmente e implementava suas táticas de repressão preventiva com base na contra-informação, a Polícia já sabia do evento 10 dias antes ${ }^{44}$. Na madrugada do dia 12 de outubro, tiros foram dados para cima. Os estudantes acordaram assustados. Estavam cercados. Era a queda de Ibiúna. Presos, foram levados ao Presídio Tiradentes (SANTOS, N., 1980). A notícia gerou manifestações em várias cidades. Em Salvador, no dia 15 de outubro, houve protestos marcados por atritos entre polícia e estudantes. Uns dando tiros; outros pedradas. Novamente, o centro virou uma praça de guerra.

No dia seguinte, o jornal $A$ Tarde publicou um Editorial na primeira página intitulado "Acabem com isto". A matéria desconhecia aquela manifestação estudantil enquanto expressiva do conjunto dos estudantes. Segundo o jornal, seria fruto de um pequeno número de "agitadores violentos", relembrando que houve apoio da sociedade à luta estudantil por melhores condiçóes de ensino e que o governo teria tomado iniciativas para resolver o

${ }^{43}$ Isto fica explícito nos depoimentos prestados pelos estudantes. BNM 71. pp 290-437.

${ }^{44}$ A respeito ver DEOPS/SP. Relatório Operação Ibiúna. XXX Congresso da Extinta UNE. São Paulo. 12 out. 1968. 
problema. Nada teria adiantado porque o que aquela "minoria de jovens" queria era a mudança do regime - embora o povo brasileiro não quisesse escravizar-se. Dizia ainda que

Ao que tudo indica, entretanto, o que é preciso já não é apontar as causas, mas sim os lugares de onde provêm a inspiração desses movimentos e os seus agentes, que devem ser quanto antes identificados e afastados de junto da juventude, a que procuram envenenar por todas as maneiras, por considerá-la a melhor linha de frente para seus desígnios demolidores. [...]

Mas, que o governo com isto procure acabar sem apelo às armas de guerra. Usar armas de fogo, que ferem e matam, contra jovens em erro político não é só uma temeridade: é uma burrice. É atender aos desígnios dos manipuladores da desordem, ávidos de sangue, com que possam sensibilizar a opinião pública, particularmente as massas trabalhadoras ${ }^{45}$.

Este trecho mostra o jornal enquadrando a opinião pública. A reportagem implicitamente contribuía para a feitura de um ambiente político de isolamento social do protesto universitário. Ainda assim, os estudantes continuaram com as manifestações. Devido ao pequeno número de participantes, com os principais dirigentes presos e em função da repressão ostensiva, os comíciosrelâmpagos foram a principal forma de luta. Eles foram realizados por diversos grupos, de locais diferentes para tentar driblar a ação da polícia. Mais uma vez, os conflitos deram o tom. Carros oficiais foram virados, depredados, pichaçóes foram feitas e os estudantes revidavam aos tiros da polícia com pedradas. No final do ato, cerca de setenta estudantes foram presos ${ }^{46}$.

Em 19/10, os delegados e observadores baianos presentes ao $30^{\circ}$ Congresso da UNE chegaram a Salvador, escoltados por agentes policiais. Foram direto para a Vila Militar, no bairro do Bonfim. Ficariam presos e incomunicáveis por alguns dias - sendo ouvidos aos poucos. Interessa dizer que todos os estudantes presos foram liberados da prisão. Seus depoimentos seriam anexados a um Processo movido pela Justiça Militar para apurar as ações do ME.

\footnotetext{
${ }^{45}$ Jornal A Tarde, 16 out. 1968.

${ }^{46}$ Jornal A Tarde, 17 out. 1968.
} 
Antes da liberação de todos os detidos, ainda seria organizada outra manifestação estudantil. Ao invés do centro, os estudantes escolheram o bairro do Comércio e, mais uma vez, ocorreram conflitos com os policiais. Houve feridos e prisóes. Uma senhora observava os acontecimentos pela janela do edifício e foi alvejada com uma bala. Repórteres da imprensa foram ameaçados. Segundo o Jornal A Tarde, o Banco do Estado da Bahia teria sido cercado por policiais que teriam alegado que um deles feriu-se quando jogaram um cinzeiro do prédio ${ }^{47}$. Tomando como base a imprensa, essa foi a última ação de rua dos universitários baianos no ano de 1968.

O desbaratamento do $30^{\circ}$ Congresso da UNE já era um demonstrativo da intolerância da repressão com a oposição. Após o Congresso de Ibiúna, muitos estudantes brasileiros foram denunciados em processos jurídicos - nalguns casos, imediatamente presos enquanto o inquérito tramitava. Em seguida à queda de Ibiúna, houve o Ato Institucional no 5 (AI-5) que praticamente fechou as possibilidades de alguma resistência legal e aberta ao regime. Também chamado de "golpe dentro do golpe", o AI-5 suspendeu o direito ao habeascorpus, instituiu a censura.

Para fechar mais o cerco ao ME, em fevereiro de 69, o Governo criou o Decreto 477. Este Decreto previa a expulsão de professores que se envolvessem em manifestações de caráter "político-partidário". Quanto aos estudantes que participassem dessas ações, seriam impedidos de se matricular por até 3 (três) anos numa Faculdade. Este decreto fecharia mais ainda as possibilidades de ação institucional do ME. Além disto, seria aplicado de modo retroativo e ilegal na UFBA, ao cassar o direito de matrícula de 72 estudantes ${ }^{48}$.

\section{Palavras finais}

É razoável pensar que, em determinado momento, a repressão abafou a capacidade do ME expressar uma resistência através dos moldes anteriores luta aberta e de massas. A violência do segundo semestre do ano de 1968 e o endurecimento nacional do regime consolidado com o AI-5 completaram o quadro de medo e cerceamento do direito à palavra. Os primeiros sinais do "milagre econômico" e a nacionalização da repressão política seriam faces da ditadura - ambas contribuindo para um freio nas manifestações de massa em oposição ao regime militar.

${ }^{47}$ Jornal A Tarde, 23/ out. 1968.

${ }^{48}$ AVANTE. UEB/DCE. 
A cassação do direito à matrícula de alguns estudantes da UFBA, em 1969, representou um atentado à autonomia universitária, sem vozes sociais à altura para uma contraposição a esta medida. Além disso, este contexto amedrontou mais ainda os descontentes, inibindo a reorganização do movimento. Por outro, representou uma quebra de laços subjetivos de enorme repercussão para a vida de muitos estudantes. Exílio, fugas, clandestinidade, processos, prisão. Desnecessário dizer que este processo de intensa repressão esvaziou a representatividade do ME e consolidou um afastamento entre os setores militantes e o estudante comum - aquele que não era cotidianamente engajado no $\mathrm{ME}$ e/ou em organizações de esquerda.

Ainda assim, a vitória da repressão não significou o fim da resistência estudantil, mas sim a sua readequação às novas formas de sociabilidade em curso à época e com impacto na universidade, notadamente após a consolidação da Reforma Universitária; às novas formas de sensibilidade coletiva; à consolidação de uma indústria cultural. Porém, isto é tema para um outro artigo.

\section{REFERÊNCIAS}

BENEVIDES, Sílvio. Proibido proibir: uma geração na contramão do poder: o movimento estudantil na Bahia e o jovem. Dissertação (Mestrado em Ciências Sociais) - Faculdade de Filosofia e Ciências Humanas - Universidade Federal da Bahia, Salvador, 1999.

BRITO, Antonio Mauricio F. Capitulos de uma história do movimento estudantil na UFBA (1964-1969). Dissertação (Mestrado em História) - Faculdade de Filosofia e Ciências Humanas - Universidade Federal da Bahia, Salvador, 2003.

D'ARAÚJO, Maria Celina et al. Os anos de chumbo: a memória militar sobre a repressão. Rio de Janeiro: Relume-Dumará, 1994 b.

1994a.

Visóes do golpe: a memória militar sobre 1964. Rio de Janeiro: Relume-Dumará,

DIAS, José Alves. A subversão da ordem: manifestaçôes de rebeldia contra o regime militar na Bahia (1964-1968). Dissertação (Mestrado em História) - Faculdade de Filosofia e Ciências Humanas - Universidade Federal da Bahia, Salvador, 2001.

DIRCEU, José; PALMEIRA, Wladimir. Abaixo a ditadura.. Rio de Janeiro: Espaço e Tempo: Garamond, 1998.

FERNANDES, Florestan. Universidade brasileira: reforma ou revolução?. São Paulo: AlfaÔmega, 1979.

MARTINS FILHO, João Roberto. Movimento estudantil e ditadura militar no Brasil:

1964-1968. Campinas: Papirus, 1987. 
- O palácio e a caserna : a dinâmica militar das crises políticas na ditadura (19641969). Tese (Doutorado em Ciências Sociais) - Universidade Estadual de Campinas, 1993. Letras, 1996.

A rebelião estudantil: 1968- México, França e Brasil. Campinas, SP: Mercado de . (Org.). 1968 faz 30 Anos. São Paulo: UFSCar, 1998.

OLIVEIRA, Antonio Eduardo Alves de. O Ressurgimento do movimento estudantil baiano na década de 70. Dissertação (Mestrado em Ciências Sociais) - Faculdade de Filosofia e Ciências Humanas - Universidade Federal da Bahia, Salvador, 2002.

OLIVEIRA, José Alberto Saldanha de. A mitologia estudantil: uma abordagem sobre o movimento estudantil alagoano. Maceió: Sergasa, 1994.

. O movimento estudantil em Alagoas: uma abordagem e algumas reflexões. In: MARTINS FILHO, João Roberto (Org.). 1968 faz 30 Anos. São Paulo: UFSCar, 1998. p 145-164.

REIS FILHO, Daniel Aarão; MORAES, Pedro de. 68: a paixão de uma utopia. Rio de Janeiro: Espaço \& Tempo, 1988.

RIDENTI, Marcelo. Em busca do povo brasileiro. Rio de Janeiro: Record, 2000.

. O fantasma da revolução brasileira. São Paulo: UNESP, 1993.

ROMAGNOLI, Luís; GONÇALVES, Tânia. A volta da UNE: de Ibiúna a Salvador. São Paulo: Alfa-Ômega, 1979.

SANFELICE, José L. O movimento estudantil e a UNE na resistência ao golpe de 64. São Paulo: Cortez, 1986.

SANTOS, Andréa Cristina. Ação entre amigos. Dissertação (Mestrado em História) Faculdade de Filosofia e Ciências Humanas - Universidade Federal da Bahia, Salvador, 2004.

- Memória da Resistência: Perfil Biográfico dos Desaparecidos Politicos Baianos na Guerrilha do Araguaia. Salvador: FACOM/ UFBA, 2001. Projeto Experimental do Curso de Graduação em Comunicação Social-Jornalismo.

SANTOS, Nilton (Org.). História da UNE. São Paulo: Livramento, 1980.

SILVA, Justina Iva da. Estudantes e política: estudo de um movimento (RN 1960-1969). São Paulo: Cortez, 1989.

SILVA, Sandra Regina Barbosa da. Ousar lutar, ousar vencer: histórias da luta armada. Dissertação (Mestrado em História) - Faculdade de Filosofia e Ciências Humanas Universidade Federal da Bahia, Salvador, 2003.

SOUSA, Janice Tirelli Ponte de. Reinvençôes da utopia: a militância política de jovens nos anos 90. São Paulo: Hackers, 1999.

VALLE, Maria Ribeiro do. O diálogo é a violência: movimento estudantil e ditadura militar em 1968. Campinas: Unicamp, 1999. 



\section{Aventuras estudantis em tempos de opressão e fuzis}

Sílvio César Oliveira Benevides ${ }^{1}$

A década de 60, no Brasil, foi um período marcado por uma gradual aproximação dos estudantes com ideologias e organizações políticas de esquerda, sobretudo após o Golpe Militar de 1964, quando as entidades estudantis secundaristas e universitárias passaram a ser dirigidas, quase totalmente, por estudantes vinculados, de alguma maneira, a tais organizações (MARTINS FILHO, 1987).

Apesar de terem em comum a luta contra a ditadura militar, as bandeiras levantadas pelos estudantes variavam devido a maior ou menor influência das diferentes organizações políticas de esquerda infiltradas no Movimento Estudantil (ME) através de muitos dos seus integrantes. Esta influência se intensificou durante o período da intervenção militar, quando os grêmios e diretórios acadêmicos passaram a sofrer a interferência direta dos organismos governamentais através da direção das escolas e faculdades.

Tão logo o golpe ocorreu, houve uma perseguição radical aos possíveis opositores do regime. Para impedir qualquer forma de organização da sociedade civil que pudesse se opor à nova ordem estabelecida, os militares determina-

${ }^{1}$ Doutor em Sociologia pelo Programa de Pós-Graduação em Ciências Sociais da Faculdade de Filosofia e Ciências Humanas da Universidade Federal da Bahia (UFBA). Professor Assistente da Faculdade de Comunicação do Centro Universitário Jorge Amado (UNIJORGE). 
ram a prisão de todas as lideranças civis consideradas potencialmente subversivas. Em todo o país foram fechadas entidades estudantis, sindicatos, redações de jornais etc. Os integrantes dessas organizações foram perseguidos e presos pela chamada "operação limpeza". As forças de oposição perderam, então, seus canais mais expressivos de atuação. Por esta razão, a efervescência estudantil nos primeiros meses do regime militar foi contida. No que diz respeito ao $\mathrm{ME}$, ele somente se reorganiza no final do primeiro mandato do presidente Castelo Branco. Na Bahia, essa reorganização se dá a partir do movimento secundarista, que tinha no Colégio Central um importante ponto de referência da mobilização estudantil.

Um dos mais tradicionais colégios públicos da Bahia e um dos primeiros a ser fundado no estado e no Brasil, o Colégio Estadual da Bahia, ou simplesmente Central, foi criado pelo Decreto Imperial n. 33, de março de 1836, sancionado pelo então vice-presidente da Província da Bahia, o desembargador Joaquim Marcelino de Brito. No entanto, somente em setembro do ano seguinte o colégio foi de fato instalado, precisamente na Rua da Palma, atrás da Mouraria, tendo como nome Lyceu Provincial da Bahia. Em 1890, o Lyceu foi extinto pelo então governador do Estado, Virgílio Clímaco Damásio, e criado o Instituto Official de Gymnásio da Bahia. Em 1942, o Gymnásio da Bahia passou a chamar-se Colégio Estadual da Bahia, período em que já se localizava no atual endereço, ou seja, na Avenida Joana Angélica, Bairro de Nazaré, região central da cidade.

Gradativamente, o Colégio Central foi se consolidando como um pólo aglutinador de conhecimento e ideias devido à qualidade dos cursos oferecidos e do seu corpo docente. Quando foi instituído como Lyceu Provincial, possuía treze cadeiras e o curso de Bacharelado em Letras. Com a extinção do Lyceu e a criação do Instituto Official de Gymnásio da Bahia, foram estabelecidos os cursos de Bacharelado em Ciências e Letras e o curso Comercial, além dos cursos de Artes. Com a reforma Francisco Campos², foram criados os cursos complementares para Direito, Medicina e Engenharia, substituídos, em 1942, pelos cursos clássico e científico, nos quais era possível aprender lições de Latim, Filosofia e Sociologia, matérias normalmente incluídas nos currículos da época. Com a lei 5.692, de 1971, foram extintos os cursos clássico e científico.

\footnotetext{
${ }^{2}$ Primeira reforma educacional de caráter nacional, realizada no início da Era Vargas (1930-1945), sob o comando do ministro da educação e saúde Francisco Campos. Essa reforma, de 1931, foi marcada, entre outras coisas, pela criação do Conselho Nacional de Educação e organização do ensino secundário e comercial. Este último foi destinado à "formação do homem para todos os grandes setores da atividade nacional", construindo no seu espírito todo um "sistema de hábitos, atitudes e comportamentos". Dessa forma, Francisco Campos havia dividido o curso secundário em dois ciclos de cinco e dois anos, respectivamente, o primeiro fundamental, e o segundo complementar, orientado para as diferentes opções de carreira universitária. (MENEZES; SANTOS, 2002)
} 
No lugar destes, se estabeleceram os cursos profissionalizantes com as respectivas habilitações. Mais tarde, os cursos técnicos substituíram os profissionalizantes.

A destacada posição do Central no ensino público da Bahia não era apenas de ordem acadêmica. O Central possuía uma vida política agitada e também se destacava pela organização das entidades representativas dos estudantes que atuaram em diferentes contextos históricos, consolidando sua tradição de escola politizada e de luta. Os primeiros registros da organização estudantil no Colégio Central datam de 1911, quando foi criado o jornal $A$ Luz, redigido e impresso pelos próprios estudantes. Nesse jornal, que no subtítulo se autodenominava de Periódico Lítero-Científico, predominavam artigos de divulgação científica e de cunho filosófico. $\mathrm{O}$ referido periódico foi editado até novembro deste mesmo ano. Em 1925, foi fundado o primeiro grêmio cujo nome homenageava o educador baiano Carneiro Ribeiro.

Em 1926, o grêmio é ampliado em seus fins, passando a se chamar Grêmio Gymnásio da Bahia. É criado o Clube de Debates, onde os estudantes se reuniam para discutir desde o destino do colégio até a situação sociopolítica do país à época. O periódico $O$ Cenáculo era o órgão de imprensa editado e redigido pelos estudantes, responsável pela divulgação dos resultados dessas reuniôes e pela divulgação de eventos culturais e esportivos organizados ou não pelo grêmio. As atividades políticas e culturais do grêmio repercutiam de tal modo que o tornou modelo para os demais grêmios das instituições de ensino da época. Em 1932, quando estoura a Revolução Constitucionalista em São Paulo, o Grêmio Gymnásio da Bahia tem suas atividades suspensas, sendo restabelecidas dois anos mais tarde, quando volta a funcionar com regularidade.

As sessões do Clube de Debates tornam-se movimentadas e o grêmio estende suas atividades para as ruas da cidade, organizando passeatas e comícios que por vezes terminavam com perseguição da polícia montada, cujas agressões os estudantes revidavam com pedradas. Em 1935, o Grêmio Gymnásio da Bahia é definitivamente extinto. Entretanto, no ano seguinte, é fundado pelos alunos dos cursos complementares o Grêmio Pedro Calmon. Seus integrantes deram continuidade à publicação do jornal $O$ Cenáculo, divulgando as atividades internas e externas organizadas pelo grêmio. Foi uma época de muitas passeatas nas quais os ideais socialistas predominavam. Diversos concursos de artes plásticas foram promovidos, além de festivais literários e musicais. No ano de 1940, o grêmio cria o Núcleo de Estudos Musicais e a Jazz Band do Ginásio da Bahia, que no ano seguinte promoveriam uma campanha pela matrícula do estudante pobre. A partir de 1942, o grêmio passou a se chamar Grêmio Colégio da Bahia. 
Em meados da década de 50, foi lançada a revista Mapa e o grêmio passou a promover teatralizaçóes de textos de autores consagrados, como Carlos Drummond de Andrade, Vinícius de Moraes, Manuel Bandeira, Cecília Meireles, Gabriel Garcia Lorca, entre outros. A partir de então, a disputa pela direção do grêmio se torna mais intensa. As eleições passam a ser palco de confrontos ideológicos. Começam, então, a surgir sérios desentendimentos entre os alunos e a direção do colégio. Nesse período, o Central consolidou definitivamente sua tradição de "reduto da inquietação estudantil". Após o golpe militar de 1964 e o posterior fortalecimento da ditadura, essa característica do Central ficou ainda mais acentuada e o colégio ganhou a fama de um estabelecimento de ensino politizado e que politizava graças à pluralidade ideológica e social do seu corpo docente e discente, o que ajudava a fomentar o debate político e intelectual. É nesse ambiente que o ME baiano pós-1964 inicia seu processo de reorganização, cujo marco inicial é justamente a greve promovida em 1966 pelos estudantes do Central (CASTRO, 1998).

Este fato fora desencadeado pela proibição da montagem da peça Aventuras e desventuras de um estudante, escrita pelo aluno e hoje publicitário Carlos Sarno (199-?). O texto está dividido em um prólogo e cinco atos: o estudante em sua terra natal, a matrícula, a primeira aula, o cotidiano na escola e a política. Inspirado na literatura de cordel, elemento da cultura popular brasileira cuja estética influenciou, naqueles anos, as experimentações artísticas do Centro Popular de Cultura (CPC), do Cinema Novo e do Tropicalismo, a peça narra a história de um estudante natural de uma região ao norte da Bahia, que migra para Salvador "pra aprender no colégio e tomar sabedoria" e assim tornar-se um doutor, como desejam seus pais, já que na cidade onde moram não há como isso acontecer.

Ao chegar à capital, a aventura estudantil do jovem protagonista tem início já na matrícula, dificultada ao máximo por uma "burocracia cem por cento um imenso curral de arquivos e documentos". A burocracia é retratada pelo autor tanto como um aparato no qual se apóiam os funcionários da escola para disfarçar a sua indisfarçável indolência, quanto um instrumento utilizado pelo Estado para ocultar um dos mais graves problemas do ensino público brasileiro, isto é, a falta de vagas nas instituições públicas, que impede o acesso de milhôes de jovens à educação. Segundo dados apresentados pelo autor, "cinco milhões de crianças brasileiras, em idade escolar, não estudam por falta de escolas”. Esse fato, porém, é apenas o princípio das mazelas da educação pública no Brasil. Ainda de acordo com os dados apresentados na peça, "de cada cem crianças que se matriculam no curso primário, quarenta e uma chegam ao segundo ano; trinta e uma ao terceiro; vinte e uma ao quarto, e apenas quinze 
concluem o curso". E os problemas não se limitam a esses. Continua o autor: "o aproveitamento médio do curso primário no Brasil é de apenas quinze por cento", enquanto "o índice de reprovação é de quarenta por cento".

Diante desse quadro, o narrador conclama os estudantes a se ocuparem também com as questóes educacionais, uma vez que uma educação de má qualidade afeta diretamente o presente do jovem e compromete, por conseguinte, seu futuro.

O que ouvimos disse tudo / já disse o nosso pensar / mostrou uma situação / que é preciso acabar / pois todos nós sabemos / seja qual seja o estudo / como é difícil estudar / neste passado presente / que acabamos de assistir / nós todos fomos um pouco / desse modo de agir. / Mas depois da nossa entrada / o assunto é esquecido / é deixado para os outros / que nele estão envolvidos. / Estou cursando o meu ano / e conseguindo estudar / o resto que quebre a bunda / tentando matricular. / Sou apenas um narrador / conversando essas conversas / não gosto de afirmar. / Mas somos homens ou merdas / preocupados em passar???!!! / que esquecemos o resto / que não pode nem entrar / somos o que afinal? / Nos preocupamos como os Beatles / isso é muito atual / nos preocupamos com as notas, / vestibular, cinema, amor / o que é muito natural, / mas com uma coisa devemos / e urgente nos preocupar / é com a nossa situação / situação dos estudantes / que precisa melhorar.

Como se vê, para a educação melhorar, não basta ocupar-se apenas das questôes educacionais. É preciso também assumir a causa estudantil como uma causa de todos e não só daqueles diretamente atingidos pelos problemas, a exemplo das dificuldades encontradas no processo de matrícula. Ademais, a participação dos estudantes é fundamental para as mudanças desejadas acontecerem, como revela o narrador: "Vamos ver! Vamos ouvir! / Vamos pensando, tentar / todo erro descobrir. / Procurem participar / fazendo seu discutir e não somente escutar / e ficar somente aí".

Essa participação, no entanto, somente é possível se o estudante tiver consciência dos seus direitos, que são direitos fundamentais do ser humano, como afirma o coro na peça.

\footnotetext{
${ }^{3}$ Grifos meus. O uso dessas expressōes foi o pretexto utilizado pela direção da escola para proibir sua montagem nos espaços da instituição, como se verá adiante.
} 
Considerar, considerar, considerar. Considerando que o desconhecimento e o abandono dos direitos do homem conduziram a atos de barbárie que revoltam a consciência da humanidade, e que o surgimento de um mundo em que os seres humanos sejam livres de falar e de crer, e libertos de terror e da miséria, tem sido proclamado como a mais alta aspiração humana; considerando que na Carta das Naçóes Unidas aos povos reafirmaram a fé nos direitos fundamentais do homem, na igualdade dos direitos dos homens e das mulheres e se declararam resolvidos a favorecer o progresso social e a instaurar melhores condiçôes de vida e um grau maior de liberdade; a ASSEMBLEIA GERAL PROCLAMA: Artigo $1^{\circ}$ - Todos os seres humanos nascem livres e iguais em dignidade e direito. São dotados de razão e de consciência, e devem agir uns em face de outros com espírito de fraternidade. Artigo $2^{\circ}$ - Toda pessoa tem direito à educação. A educação deve ser gratuita, pelo menos no que concerne ao ensino elementar e fundamental. O ensino elementar é obrigatório. O ensino técnico e profissional deve ser generalizado; o acesso aos estudos superiores deve ser aberto a todos, em plena igualdade, em função das capacidades de cada um.

A luta maior dos estudantes, na década de 60 , era relativa às condiçôes do ensino. Preservar a qualidade da educação pública e gratuita era uma reivindicação que por vezes se confundia com a defesa da democracia e dos direitos humanos, pois a educação pública e gratuita fornece aos estudantes das diversas camadas sociais a possibilidade de ascender socialmente, assim como adquirir um grau de consciência política e social mais ampla. A movimentação estudantil propriamente dita desse período teve como um dos centros mais importantes justamente a defesa da escola pública. A passagem dos temas propriamente estudantis para temas políticos mais gerais se deve ao fato de o ME ter sido pouco a pouco atraído por projetos de outros grupos de pressão com os quais foi chamado a colaborar, graças, sobretudo, à influência das organizaçôes políticas de esquerda infiltradas no interior do movimento (ALBUQUERQUE, 1977).

A crítica empreendida por Carlos Sarno ao sistema educacional brasileiro também é direcionada aos modelos pedagógicos utilizados por alguns professores, muito mais preocupados em informar "a todos só o que preste", do que formar, ou seja, educar para o exercício da cidadania. Em um dos trechos 
do texto, enquanto um professor se queixa de que "aluno não presta atenção em coisa alguma, onde já se viu”, pois preso está às suas práticas arcaicas que não mais contemplam os desejos e anseios daqueles para os quais leciona, o protagonista se pergunta: "Para onde vou? (O mundo inteiro nota, 'e a nota'). Nos meus olhares fúnebres carrego a indiferença estúpida de um cego e o olhar indolente de um chinês idiota”.

Essa passagem ilustra bem o que Mead (1970) denomina de forma cultural prefigurativa no que diz respeito ao ciclo das gerações. $\mathrm{O}$ principal elemento que caracteriza uma forma cultural predominantemente prefigurativa é o fato de os jovens, e não mais os seus pais ou avós, representarem o que está por vir. Diante de tantas mudanças, desencadeadas, sobretudo, pelos avanços tecnológicos, as geraçôes mais velhas se deparam numa cultura prefigurativa com uma situação semelhante a dos primeiros imigrantes europeus que se estabeleceram na América, os pioneiros. Todavia, ao invés de imigrantes no espaço, os mais velhos na década de 1960, aqueles nascidos antes da Segunda Guerra Mundial, passaram a ser imigrantes no tempo (MEAD, 1970). Seus valores e crenças apenas em parte se adequavam a uma nova realidade de incríveis avanços tecnológicos e mudanças velozes. Para estes, cada conquista tecnológica se constituía numa novidade a qual eles tinham que se adaptar. Para os jovens, no entanto, nascidos e criados num mundo jamais visto pelos mais velhos, essas mesmas conquistas não passavam de uma experiência corriqueira e bastante familiar. Por tudo isso Mead (1970) afirma que sua geração tinha medo da geração do pós-guerra, pois esta nascera num mundo fortemente influenciado pela tecnologia, o que propiciou um afastamento radical entre os jovens desse período e seus predecessores, marcando definitivamente, segundo ela, o surgimento da forma cultural prefigurativa.

Entre as décadas de 40 e 60 , ocorreram diversos fatos nas mais diferentes áreas do conhecimento humano que modificaram de uma vez por todas a relação do homem com a natureza e do homem com seu semelhante. A invenção do computador; a divisão do átomo, cujos perigos do mau uso se fizeram conhecer com a explosão de duas bombas atômicas sobre o Japão; a emergência da bioquímica; a descontrolada expansão demográfica em escala mundial, que faria aumentar significativamente a população jovem de diversos países; o crescimento desordenado das grandes cidades; a destruição do meio ambiente; novas descobertas na medicina, sobretudo no tratamento de doenças; os avanços tecnológicos nas telecomunicações e nos transportes, o que acabou encurtando as distâncias geográficas e consequentemente as culturais; a conquista 
espacial, dentre tantos outros acontecimentos de grande impacto, provocaram uma drástica e irreversível divisão entre as gerações (MEAD, 1970).

Nesses tempos de rápidos avanços tecnológicos, os mais jovens se tornaram aos olhos dos mais velhos seres estranhos, que se negando a aceitar os modelos de padronização e igualdade de comportamento, passaram a ser rotulados de transviados, desequilibrados, delinquentes, rebeldes, loucos ou simplesmente anormais, por se interessarem por temas considerados inapropriados para um jovem, como a política, por exemplo. Dessa oposição de ideias e visões de mundo surge o conflito ou abismo entre gerações, responsável por criar grandes dificuldades de comunicação entre jovens e velhos (MEAD, 1970).

Esse abismo entre os mais velhos e os mais jovens pode ser percebido quando o texto aborda na cena cinco o tema da política. A cúpula, representando a direção da escola (metáfora do autoritarismo do Estado instaurado com o golpe militar?), informa aos estudantes qual sua principal função. "Nós, a cúpula, decidimos / que cada um deve cumprir / deve pensar, deve sentir / aquilo que sentimos / porque somos a razão / e como nós representamos a todos / para todos decidimos / a nossa decisão".

Mas o estudante, símbolo de uma nova geração ávida por mudanças e por liberdade de expressão, retruca:

Discordo, meu caro amigo / do que acabas de afirmar / "política não é comigo / que eu quero estudar" / discordo de quem não sabe / do que mesmo vem a ser / política e estudar / e vive assim sem saber. / A política é o estudo do que somos agora / do que deixamos de ser / do que hoje não temos / e que amanhã pode ter / o que você confiante / pensando só na aulinha / dá ao líder inconsciente / dá à cúpula sabidinha / e que mesmo a sua aulinha / é deficiente e ruim / e que você sem política sempre terá aula assim / agora vou subir / por pura delicadeza / para a cúpula desfingir / e dar maior certeza / iluminar este palco / e a alma deles também / pra ver de perto o rosto / o de dentro que eles têm.

Como se vê, o desejo do estudante retratado no texto do Carlos Sarno é o de ter uma educação voltada não apenas para a transmissão de informações, mas, sobretudo, de conhecimento que possibilite formá-lo como ser humano, 
cuja condição, em todos os seus aspectos, tem alguma relação com a política, conforme ressalta Arendt (2001).

De acordo com o próprio Carlos Sarno ${ }^{4}$, a peça Aventuras e desventuras de um estudante era, na verdade, um pretexto para chamar atenção do estudante para a importância da atividade política como o único caminho possível para a transformação de uma dada realidade. Em uma das cenas, por exemplo, mais especificamente a que retrata a morte do grêmio, representação política dos estudantes, dois coveiros dialogam, contemplando o defunto: "A sua morte é a nossa omissão. / A sua vida é a nossa consciência. / A sua morte é a nossa ausência. / A sua vida é a nossa mão". E concluem o diálogo, incitando a plateia:

A nossa mão / que coveiros e estudantes / é tudo a mesma coisa / porque se há alguéns, e há / que decretaram a sua morte / há aqueles (nós) que a cumprimos / mas a sua vida é a nossa mão / que forte e decidida / dará a sua morte, vida / dará a sua vida, ação. / Que o defunto grêmio reapareça / que não tema nem obedeça / que saia da sua morte / que seja sempre forte / para nós, por nós / ESTUDANTES.

Para o então diretor do Colégio Central, Walter Reuter, porém, o conteúdo do texto era inadequado para um estabelecimento de ensino, pois em algumas passagens eram utilizadas palavras inapropriadas como "merda" e "bunda". Com os protestos sucedidos em decorrência de tal proibição, a direção da escola decidiu suspender por tempo indeterminado todos os estudantes vinculados ao Grupo Amador de Teatro da Bahia (GATEB), responsável pela encenação. Em resposta a esta última determinação, os estudantes decretaram greve e saíram às ruas para protestar. Para Carlos Sarno, o fato serviu de estopim para se discutir a repressão do regime, assim como para dar vazão a uma rebeldia já latente nos jovens daquela geração, que tomou conta das ruas da cidade através de inúmeras passeatas 5 .

Não podendo apresentar a peça dentro do Colégio Central, os estudantes, apoiados pelos universitários e pelo então abade do Mosteiro de São Ben-

\footnotetext{
${ }^{4}$ Entrevista concedida em 6 out. 1994.

${ }^{5}$ Entrevista concedida em 6 out. 1994.

${ }^{6}$ De acordo com Carlos Sarno, Dom Timóteo Amoroso Anastácio chamou os estudantes do GATEB e justificou seu apoio ao grupo da seguinte maneira: "Vocês são marxistas, mas são a chama de Deus". (Entrevista concedida em 6/ out. 2008).
} 
to, Dom Timóteo Amoroso Anastácio ${ }^{6}$, resolveram encená-la na Residência do Universitário, que na noite da apresentação estava repleta de estudantes, além de outras pessoas que lá se encontravam especialmente para ver a encenação. Essa tentativa de exibição da peça contrariava uma resolução do então governador do Estado, Lomanto Júnior, que, através da Secretaria de Segurança Pública, proibira qualquer tipo de manifestação de rua, passeatas e agrupamentos em frente a estabelecimentos de ensino ou próximos das universidades, colégios e ginásios estaduais.

Tal medida fora tomada como represália ao acontecimento envolvendo o então Ministro das Relações Exteriores, General Juraci Magalhães, que na tarde do dia 04/06/1966, ao retornar da residência do seu filho, fora vaiado e alvo de algumas pedradas em frente a Reitoria da Universidade Federal da Bahia (UFBA), na ocasião em que centenas de universitários saíam de uma assembleia onde se decidira a realização de uma greve de 48 horas em protesto contra a proibição da peça dos estudantes do Central. Para fazer valer a determinação do governador, a polícia invadiu a Residência do Universitário e espancou vários estudantes que lá se encontravam.

A greve dos estudantes do Central, em junho de 1966, se constituiu, em Salvador, na primeira grande manifestação estudantil contra o governo. A proibição da peça Aventuras e desventuras de um estudante paralisou todo o colégio e acabou desencadeando em outros estabelecimentos de ensino secundário e universitário, a exemplo da Escola de Eletromecânica e do Colégio Aplicação, das Escolas de Geologia, Teatro, Música e Filosofia da UFBA, além de entidades como União dos Estudantes da Bahia (UEB) e do Teatro Experimental de Feira de Santana (TEF), uma série de protestos em solidariedade aos estudantes grevistas e contra a intransigência da direção da instituição. Desta maneira, os estudantes baianos, de acordo com Castro (1998), reativaram a manifestação pública contra a ditadura militar e, por conseguinte, provocaram a primeira ação repressiva organizada contra o ME após 1964, quando o regime militar foi instituído através de um golpe.

\section{REFERÊNCIAS}

ALBUQUERQUE , J.A. Guilhon. Movimento estudantil e consciência social na América Latina. Rio de Janeiro: Paz e Terra, 1977.

ARENDT, Hannah. A condição humana. Rio de Janeiro: Forense Universitária, 2001. 
BENEVIDES, Sílvio César Oliveira. Na contramão do poder: juventude e movimento estudantil. São Paulo: Annablume, 2006.

BRASIL. Supremo Tribunal Federal. José Marcelino de Brito. [19-?]. Disponível em: <http://www.stf.jus.br/portal/ministro/presidente.asp?periodo=stj\&id=289>. Acesso em 13 out. 2008.

CASTRO, Ubiratan. 1968 - o movimento estudantil na Bahia: um testemunho. Salvador: [s.n.], 1998. Mimeo.

MARTINS FILHO, João Roberto. Movimento estudantil e ditadura militar: 1964-1968. Campinas: Papirus, 1987.

MEAD, Margaret. Culture and commitment: a study of the generation gap. New York: Natural History: Doubleday \& Company, 1970.

MENEZES, Ebenezer Takuno de; SANTOS, Thais Helena dos. Reforma Francisco Campos. (verbete). In: DICIONARIO Interativo da Educação Brasileira - EducaBrasil. São Paulo: Midiamix, 2002. Disponível em: <http://www.educabrasil.com.br/eb/dic/ dicionario.asp?id=372>. Acesso em: 13 out. 2008.

SARNO, Carlos. Aventuras e desventuras de um estudante. [199?]. Disponível em: <http:// www.diariosdaditadura.com.br/tcc_mat_ver.asp?cod_col=38>. Acesso em: 21 set. 2008.

WELDON, Americano da Costa. Memória histórica do Colégio Estadual da Bahia. Salvador: Imprensa Oficial da Bahia, 1971. 



\title{
Bandeira vermelha:
} aspectos da resistência armada na Bahia

\author{
Sandra Regina Barbosa da Silva Souza ${ }^{1}$
}

O nosso objetivo neste artigo consiste em apresentar, de maneira sucinta, alguns aspectos da formação das organizações políticas armadas urbanas que atuaram em Salvador, notadamente a Vanguarda Armada RevolucionáriaPalmares (VAR-Palmares), o Partido Comunista Brasileiro Revolucionário (PCBR) e o Movimento Revolucionário Oito de Outubro (MR-8), restrito aos limites temporais de 1969 a 1971. Na Bahia, militantes de esquerda conforme a caracterização de "esquerda" de Norberto Bobbio $(1995)^{2}$-e representantes das forças de repressão do regime militar protagonizaram episódios de confrontação. Diferentemente do que ocorre com estados como o Rio de Janeiro, São Paulo e Minas Gerais, a Bahia não é mencionada, na bibliografia, como um local relevante na oposição ao regime ditatorial, em geral, é citada de forma breve, em circunstâncias específicas, como por exemplo, na abordagem da morte de Carlos Lamarca, ocorrida no interior do Estado. Nas entrevistas com alguns ex-militantes das organizações armadas pesquisadas, constatamos

\footnotetext{
${ }^{1}$ Doutora em História Social pela Universidade Federal da Bahia (UFBA). Atualmente desenvolve pesquisa sobre comunismo e anticomunismo durante a ditadura militar nos anos 60 e 70.

${ }^{2} \mathrm{O}$ autor define "esquerda", como igualitária e coletivista, tendo como principal propósito a diminuição das desigualdades sociais e a extinção da propriedade privada. O termo "esquerda" é usado também para nomear as "forças políticas críticas da ordem capitalista estabelecida, identificadas com as lutas dos trabalhadores pela transformação social.” (Cf. RIDENTI, 2000)
} 
uma tendência a destacar, explicitamente, a Bahia como "área de recuo", uma ideia para nós não resolvida, e que nos conduziu à presente pesquisa ${ }^{3}$ sobre a forma como ocorreu a resistência da esquerda armada. A princípio, Salvador foi considerada "área de recuo", no sentido de ser preservada de açôes que atraíssem a atenção da ditadura militar, situação que prevaleceu até a expropriação realizada pelo PCBR ao Banco da Bahia, localizado no bairro da Liberdade, em 1970.

Organizações como a VAR-Palmares e o MR-8 consideravam que Salvador deveria ser resguardada para a possibilidade de refugiar militantes procurados pela repressão em outros estados brasileiros. Porém, acreditamos que na dinâmica da guerrilha, a circulação de quadros de uma área onde estivessem "queimados" para outra onde não eram conhecidos, foi uma ocorrência natural, não se constituindo num elemento essencial para a caracterização de uma "área de recuo". Sob essa perspectiva, cidades como o Rio de Janeiro e São Paulo poderiam ser consideras também como "área de recuo" para alguns militantes "queimados" que saíram da Bahia por motivos de falta de segurança. Contudo, as ações armadas em Salvador foram, em comparação com o eixo Rio-São Paulo, significativamente menos intensas, porém não foram nulas.

Com a finalidade de apreender a trajetória das lutas de oposição armada ao regime militar em Salvador durante os anos de 1969 a 1971, foram utilizados dados contidos nos interrogatórios e relatórios de cópias dos processos do Departamento da Polícia Federal - Delegacia Regional da Bahia - e da Auditoria da Sexta Circunscrição Judiciária Militar - Exército, Marinha e Aeronáutica -, encontrados no Fundo: Brasil Nunca Mais (BNM), pertencente ao Arquivo Edgard Leuenroth, sob a administração da Universidade de Campinas. $^{4}$

\footnotetext{
${ }^{3}$ Este artigo está ancorado em algumas reflexões desenvolvidas no segundo capítulo da minha dissertação de mestrado em História Social - UFBA, defendida em 08/10/2003. Infelizmente não foi possível, neste artigo abordar o cotidiano das organizações, a vida na clandestinidade, a sua composição social, bem como a desestruturação das mesmas cujo último desfecho foi a morte de Carlos Lamarca no interior da Bahia, no ano de 1971.

${ }^{4}$ O Fundo Brasil Nunca Mais é o resultado de levantamento e pesquisa coordenada pela Arquidiocese de S. Paulo, junto à documentação oficial produzida pela Justiça Militar durante o período de 1964 a 1979. Encontra-se composta por 707 processos, referenciados através de 12 volumes de índice que localizam nomes de processados, testemunhas, organizações políticas de esquerda, data e locais, alem de funcionários da repressão (delegados, médicos legistas etc.). O Fundo, conta ainda com o Arquivo Anexo, com mais de 10.000 documentos: panfletos, jornais, textos de discussōes teórica e prática produzidos pelos grupos de esquerda envolvidos na luta contra a repressão. $\mathrm{O}$ acervo contém ainda cerca de 250 fotos de militantes, de manifestaçôes etc. Por cláusula contida no termo de doação, o Fundo Brasil Nunca Mais pode ser livremente reproduzido no arquivo citado. Cada um dos processos contém, em média, 1500 folhas. Sobre o MR-8, ver BNM 192/71, que apura toda a estrutura e o funcionamento dessa organização armada na Bahia, a partir da prisão de 25 militantes; BNM 52/71, processo em nome de Olderico Campos Barreto que apresenta a tentativa de implantação do MR-8 no interior da Bahia, na região de Brotas de Macaúbas, o cerco e as mortes de Luis Antonio Santa Bárbara, Otoniel Campos Barreto, José Campos Barreto e Carlos Lamarca; Sobre o PCBR ver
} 
Uma das preocupações metodológicas da pesquisa foi a análise da natureza dos processos, no que se refere à problemática em relação às condições de torturas físicas e psicológicas em que foram realizados os interrogatórios perante os órgãos militares, ou seja, era o momento em que se extraiam "o máximo de informaçōes no mais curto espaço de tempo possível, para que pudessem efetuar mais prisóes antes que os amigos e companheiros do prisioneiro ficassem sabendo da sua prisão e desaparecessem" (WESCHLER, 1990, p. 23).

Sobre as formas de extrair informações dos prisioneiros, o general Adyr Fiúza de Castro ressaltou que "tinha um prazo de 5 horas para tirar todas as informações possíveis, onde era o aparelho e qual seria o próximo ponto [de encontro]". (D’ARAÚJO et al., 1994, p. 35). Havia, também, a possibilidade do preso negar em tribunal todas as informaçóes prestadas anteriormente. Por todos esses fatores, cuidadosamente observamos as informaçôes dos militantes em momentos distintos do processo, com o objetivo de perceber possíveis mudanças no conteúdo de um interrogatório para outro. Entendemos, que muitas vezes, sob coação física, os interrogados poderiam fazer afirmações sem propósito, criar situações falsas ou verossímeis apenas para livrar-se dos horrores da tortura.

Ainda que uma das nossas fontes sejam os processos militares, não foi nosso objetivo produzir uma versão oficial da luta armada em Salvador. Esses processos revelaram-se um material extremamente rico e complexo, que exigiu um cuidadoso e exaustivo trabalho de crítica e interpretação a partir do cruzamento com as entrevistas, ou seja, o essencial para a pesquisa foi mesmo a confrontação das informações contidas nos processos e entrevistas. ${ }^{5}$ Nessa prática, foram cotejadas as fontes processuais com os dezesseis depoimentos orais colhidos diretamente na forma de entrevistas gravadas com ex-militantes: cinco do PCBR, cinco do MR-8 e seis da VAR-Palmares. Todas elas contribuíram inquestionavelmente na reconstituição da memória das organizações da esquerda armada urbana baiana. Os depoimentos, em geral, foram bastante ri-

BNM 91/70, que também apura a estrutura do PCBR, BNM 212/70, sobre a morte do Sargento da Aeronáutica, cujos principais envolvidos são os militantes Theodomiro Romeiro dos Santos e Paulo Pontes da Silva, BNM 612/70 que investiga o assalto ao Banco da Bahia na Liberdade, realizado pelo PCBR; BNM 271/70 sobre o funcionamento da VAR-Palmares. Consultamos ainda um depoimento do BNM 363/70, sobre o PCBR/PC do B em Ilhéus, cedido pela pesquisadora Andréa Santos. Contabilizamos um total de 31 processos sobre a esquerda na Bahia, durante o período de 1964 a 1973, 28 sobre Salvador, 2 em Ilhéus e um a respeito de Feira de Santana.

\footnotetext{
${ }^{5}$ Vale ressaltar que os depoimentos de sete pessoas, das 16 entrevistadas, foram confrontados com os seus interrogatórios que integram os respectivos processos, arquivados no BNM. Na dissertação, ainda trabalhamos com os jornais A Tarde e Jornal da Bahia, veículos constantes de divulgação e/ou crítica das açốes dos militantes e das organizaçôes armadas. Algumas notícias dos jornais trazem a descrição dos eventos, passeatas estudantis, prisões de militantes e apreensões de materiais, registrando-se a presença dos agentes sociais no processo de oposição à ditadura vigente.
} 
cos em informações, análises e, por alguns entrevistados, carregados de emoção. Apesar da elaboração prévia de uma lista de perguntas que interessavam à pesquisa, os ex-militantes foram solicitados a discorrer livremente sobre o tema, intercalamos, vez por outra, questôes relevantes para o esclarecimento de determinados aspectos: motivações que os levaram a optar pela luta armada; a vida na clandestinidade; as ações das quais participaram, assim como a estrutura e os níveis hierárquicos daquela organização armada, à qual estiveram vinculados. Elementos cotidianos, referências a lugares, costumes diários, preferências artísticas, relacionamentos familiares, determinadas informações de suas trajetória em reuniōes clandestinas, "pontos" marcados em praias e portas de cinemas e todo um universo que ainda permanecia oculto sobre a historia da esquerda armada baiana, foram possíveis, apenas, de serem revelado em sua riqueza de detalhes pelos próprios envolvidos.

A escolha dos depoentes, foi determinada por critérios como: o grau de envolvimento na organização, dirigentes, militantes de base ou simpatizantes. Muitas vezes, nos baseamos nos dados contidos nos processos, em outras procuramos nomes já consolidados pela bibliografia que havia sobre o tema. Assim apresentamos os depoimentos, no sentido de "preencher as lacunas" deixadas pelas fontes escritas, buscando dados informativos e factuais da vivência clandestina nas organizações armadas. ${ }^{6}$

A tônica da luta em Salvador teria sido de reação, de uma defesa dos direitos democráticos cerceados pelo poder ditatorial implantado, sobretudo após o Ato Institucional $\mathrm{n}^{0} 5 .^{7}$ Os depoimentos unanimemente sugeriram que o Ato Institucional n. 5 (AI-5) foi a razão fundamental para a opção pela resistência armada, ou seja, o estreitamento dos canais legais de atuação oposicionista depois do golpe de 1964, sobretudo a partir de 13 de dezembro de 1968, teria criado condições para adesões às organizações armadas. A radicalização do regime militar com o AI-5, trouxe, para muitos jovens baianos, a confirmação de que vias pacíficas não bastariam para reconquistar a liberdade e acabar com o regime autoritário no Brasil. A impossibilidade de se fazer "movimento de massa", ou seja, o fechamento total da ditadura militar dificul-

\footnotetext{
${ }^{6}$ Recorreu-se, também, a documentos manuscritos, mimeografados, datilografados, de produção e circulação clandestinas, para debate e divulgação de idéias, contendo teses sobre realidade brasileira do período, análises do caráter da revolução brasileira, um esboço da linha de atuação com propostas para a luta armada, planejamento de treinamento de tiro, avaliação e autocrítica do militarismo e das ações armadas, cartas de militantes, panfletos e periódicos pertencentes à VAR-Palmares, PCBR e MR-8, suscitando uma série de questionamentos pertinentes ao objeto de pesquisa.

${ }^{7}$ Promulgado em 13 de dezembro de 1968, o Ato Institucional n. 5, representou o completo fechamento do regime militar. Não havia prazo estipulado para sua vigência e passariam a ser permanentes os controles e a suspensão de garantias institucionais. Ver: Alves (1987, p. 131).
} 
tou o trabalho político que se fazia anteriormente, sobretudo pelos estudantes. Renato da Silveira, professor, designer gráfico e artista plástico desde 1967, exmilitante do MR-8, afirmou que o seu ingresso na atividade política se deu através da arte e pela falta de liberdade de expressão imposta pelo AI-5:

Eu comecei, na verdade, como militante artístico, em 1966. Teve aqui na Bahia uma grande Bienal de Artes Plásticas, uma Bienal Nacional, organizada pelo Juarez Paraíso. [...] A minha primeira militância foi de luta contra a arte decorativa, a arte que não se voltava para as realidades sociais, e pela procura de novos espaços. Nós fazíamos exposições em faculdades, em sindicatos, nas ruas, e muito próximo das organizaçóes de esquerda. Naquela época, era uma arte engajada, arte de denúncia. Mas vem o AI-5 e fica difícil ser artista, por que os espaços todos se fecharam, existiam espiōes em toda parte, em todo lugar onde existia gente aglomerada discutindo, tinha pelo menos um espião da repressão. A partir daí, fazer militância como artista ficou praticamente impossível. A minha opção foi abandonar a arte, eu abandonei completamente a arte, e entrei numa organização que era a princípio a Juventude do Partido Comunista da Bahia. Nesse momento, eu me tornei militante mesmo, com uma vida clandestina toda organizada [...] $\mathrm{Na}$ verdade, foi a falta de possibilidade de exercer a minha profissão de artista engajado, solidário com as lutas do povo brasileiro, que me levaram para a luta clandestina ${ }^{8}$.

Na proporção em que os estudantes foram investindo mais intensamente nas discussões sobre luta armada e se preparando como "quadro", ou seja, militantes profissionais, iam se afastando da frente de massas e entrando na clandestinidade por questôes de segurança. A preparação militar mínima era obrigatória, os encontros somente em pontos previamente marcados, com senhas, não se permitindo atrasos. Compreendendo que o momento posterior ao AI-5 caracterizava-se, particularmente, pela falta de alternativa para mobilização legal, a atividade estudantil reduziu-se ao que foi denominado pelo nosso depoente de "ação clandestina de massa", que consistiu na colação

\footnotetext{
${ }^{8}$ Entrevista com Renato da Silveira.

9 Entendemos como "quadro" de uma organização, o militante "profissional", o que está mais preparado qualitativamente, o quadro de direção ou o militante em tempo integral.
} 
de cartazes e panfletos nas paredes, na distribuição de alguns informes e difusão de boatos. ${ }^{10}$

Segundo Ridenti (1993), já em meados de 1968, havia uma tendência à migração dos militantes do movimento estudantil de seus grupos estudantis para as organizações de esquerda, que apresentavam como meta prioritária a guerrilha rural. Em Salvador, ainda no final de 1967, como resultado das dissidências do Partido Comunista Brasileiro (PCB), temos conhecimento de um grupo de estudantes baianos, basicamente secundaristas, que já constituíam duas correntes independentes, ou seja, duas dissidências do PCB local, e que, durante as movimentações estudantis de 1968, já atuavam organizadamente: uma sob a liderança de Juca Ferreira e Sérgio Landulfo Furtado e a outra, coordenada por Chantal Russi, Marie Hélène Russi, Carlos Sarno e Jurema Valença. A essas duas tendências dissidentes faziam parte, inicialmente, um único grupo de estudantes, proveniente, em grande medida, do Colégio Estadual da Bahia, Colégio "Central", mais alguns estudantes da Escola Técnica Federal da Bahia e do Colégio Severino Vieira. ${ }^{11}$ Esses estudantes tiveram presença marcante nas movimentações estudantis durante os anos de 1966 até 1968 sob forte influência do PCB, contudo, é bom ressaltar que o ingresso de alguns desses jovens no partido ocorrera com o fim de provocar uma cisão, cujo objetivo era criar uma dissidência que comungasse com uma concepção de rompimento mais radical com o regime militar. ${ }^{12}$

A princípio, esses estudantes vão agrupar-se, cada um deles, de acordo com suas preferências ideológicas e afinidades com os métodos utilizados para a derrubada do governo militar no Brasil. Nesse momento, esses estudantes, já vão atuar, organizados no interior das dissidências de forma semiclandestina, alguns deles adotando codinomes. Ambas as tendências, no interior da dissidência do $\mathrm{PCB}$, aos poucos vão se afastando dos movimentos de massa de outros tempos, assumindo algumas atitudes de viés militarista na confrontação com o regime - como, por exemplo, a busca de treinamento militar -, embora esses grupos não se assumissem dentro da chamada "linha militarista" ${ }^{13}$. Ao

\footnotetext{
${ }^{10}$ Entrevista com Ubiratan Castro de Araújo.

${ }^{11}$ Podemos citar dentre outros, os estudantes Carlos José Sarno, Jurema Augusta Ribeiro Valença, Marie Hélène Russi, Chantal Russi, Nemésio Garcia, Getúlio Gaspar Gouveia, Rui Pinto Paterson, Israel Oliveira Pinheiro, Maria Célia Mascarenhas Magalhães, Sérgio Landulfo Furtado, José Carlos Souza, Ubiratan Castro de Araújo, Carlos Moreira Villanueva, Denílson Ferreira de Vasconcelos, João José Reis e João Luis da Silva Ferreira (Juca Ferreira).

${ }^{12}$ Entrevista com Jurema Valença.

${ }^{13}$ Cabe aqui um esclarecimento de ordem semântica. O termo "militarismo" recebeu entre as esquerdas o significado de predomínio da tendência para a luta armada imediata. Organizaçōes de esquerda militarizada eram aquelas que adotavam formas de luta e de propaganda armada e desprezavam o trabalho de massas. (GORENDER, 1990)
} 
entrevistarmos os militantes que estiveram na liderança das duas tendências, cada entrevistado declarou que o outro grupo dissidente, naquele momento, assumira atitudes militaristas e vanguardistas em detrimento das atividades políticas junto aos estudantes e operários. ${ }^{14}$

Mas o rompimento motivado quanto à forma de resistência à ditadura, não foi o único ponto de divergência, uma outra resposta freqüente refere-se à divisão por afinidades pessoais, ou seja, as amizades constituídas ainda no movimento secundarista do colégio "Central" também teriam sido uma motivação para a cisão da Dissidência Comunista da Bahia (DI-BA) em dois grupos distintos, com estruturas e ligaçóes com outros estados diferenciados: um ligado ao MR-8 e outro à VAR-Palmares. ${ }^{15}$ Por exemplo, os militantes, Juca Ferreira e José Carlos Souza, utilizam o mesmo argumento, e justificam que o rompimento foi causado pela posição mais "vanguardista" e "militarista" adotada pelo outro. Juca Ferreira relatou que:

[...] logo depois de nós rompermos com o PCB, meses depois, rachou em dois, porque tinha um pessoal que era abertamente guevarista, trabalhava com a perspectiva do foco guerrilheiro, a gente os chamava de militaristas. Preparação de uma coluna guerrilheira, escolha da área, ação armada na cidade para criar infra-estrutura, era uma coisa que subestimava a ação política. E nós, outro grupo, tínhamos a tese das ações político-militares. As ações armadas deveriam ser para fazer propaganda de um projeto político. Deveríamos ter enraizamento nas classes sociais, era um pouco mais sofisticado teoricamente.

O grupo que se aproximaria da VAR-Palmares também afirmou na época defender as ações "político-militares", onde a ação militar estava subordinada à propaganda de um projeto político. Essa caracterização foi encontrada em Carlos Sarno e Ubiratan Araújo para justificar o distanciamento em relação ao grupo liderado por Juca Ferreira e Sérgio Furtado. Em depoimento, Sarno mencionou que durante o Congresso de Ibiúna ocorreram contatos do seu

\footnotetext{
${ }^{14}$ Entrevistas com Carlos Sarno, Ubiratan Araújo, Renato da Silveira, Juca Ferreira, José Carlos Souza, Jurema Valença.

${ }^{15}$ Perguntamos, insistentemente, aos nossos entrevistados o motivo do "racha” na Dissidência do PCB na Bahia. Em grande medida, as respostas coincidiram que uma suposta inclinação "militarista" do "outro grupo" levou á separação. Ver depoimentos de Carlos Sarno, Jurema Valença, Israel Pinheiro, Ubiratan de Castro Araújo, Renato da Silveira, José Carlos Souza, Juca Ferreira.
} 
grupo com a Dissidência de São Paulo, no que facilitou a integração com a VAR-Palmares, e também relatou que alguns fatores que provocaram a divisão da DI-BA foram:

Priorizávamos a atividade política de organização operária, de articulação e uma rede de apoio de inserção social. Havia uma corrente mais voltada para a ação armada, para uma discussão de foco, de vanguarda [...] esses foram os motivos, apesar das ligaçóes pessoais que a gente tinha. [...] A gente começou a se ligar mais ao pessoal de São Paulo, mais voltado para discussóes políticas [...] as afinidades do ponto de vista político com a VAR-Palmares, de organização dos trabalhadores nas cidades, a instância política, foram também importantes.

\section{Formação das organizações armadas em Salvador}

O grupo da DI-BA, que, posteriormente, se integraria à VAR-Palmares, estruturou-se em Salvador, a partir de março de 1969, marcado o seu início em uma reunião realizada no bairro de Pirajá, na qual foi definida a linha de atuação da organização clandestina. Nessa reuniāo de fundação, primeira etapa de estruturação que, segundo informações de um dos participantes, durou quatro dias, teriam acontecido apenas discussóes teóricas sobre problemas regionais, brasileiros e internacionais. ${ }^{16}$ Num segundo momento, alguns dias depois, em outra reunião, numa fazenda localizada em Inhambupe, interior do estado, de propriedade do pai de um dos militantes, foram acordadas as bases da organização e definidos seus modos de atuação, assim como, a distribuição de tarefas e a divisão hierárquica entre os participantes. ${ }^{17}$

Ora, não nos parece, portanto, incorreto afirmar que, o final do ano 1968 e o primeiro semestre de 1969, sem dúvida, foi o momento de consolidação política da DI-BA através de discussões sobre as diversas organizações de esquerda armada implantadas no Rio de Janeiro e São Paulo, realizadas com o propósito de escolher aquela que melhor se adequasse às suas exigências. Já no segundo semestre de 1969, o grupo sob a liderança de Carlos Sarno, Chantal

\footnotetext{
${ }^{16}$ Dessa fase de integração e estruturação da organização em Salvador, participaram apenas Chantal Russi, Marie Hélène Russi, Nemésio Garcia, Jurema Valença, Antonio Argolo, Getúlio Gouveia, Carlos Sarno, Denílson Ferreira de Vasconcelos, Wanderlan Macedo, Wanderley Macedo (estes dois últimos, originários da militância de Alagoinhas).

${ }^{17}$ Confira BNM (192, 1971, p. 59-60, 328).
} 
Russi, Jurema Valença, resolve enviar Getúlio Gouveia e Marie Hélène Russi, os principais "quadros" da organização, para fazerem contato e discutirem formas de inserção política com a VAR-Palmares, porém, isto não se concretiza nesse momento, devido à prisão de ambos, quando tentavam embarcar na Rodoviária de Salvador, no dia 2 de setembro daquele ano. ${ }^{18}$ Jurema Valença narrou esse episódio:

Éramos todos seguidos o tempo inteiro [...] então foram prender Marie Hélène que estava seguindo com Getúlio Gouveia para o Rio de Janeiro para discutir o nosso ingresso grupo do Rio de Janeiro. Eles estavam indo fazer as discussōes políticas e Getúlio estava armado. Na hora que Marie é presa na Rodoviária, Getúlio saca a arma, quando Getúlio saca a arma a polícia cai em cima dele, e os dois vão presos. Quando Marie vai presa com Getúlio, a gente dispersa porque eles sabiam que nós éramos do mesmo grupo [...] nós estávamos sempre juntos, e, éramos do movimento de massas, éramos da frente, não fazíamos um trabalho clandestino, fazíamos um trabalho público, e, eu já tinha sido presa uma vez no movimento de rua, numa passeata.

Após a prisão de Marie Hélène Russi e Getúlio Gouveia, o grupo se dispersa inicialmente para cidades do interior, a exemplo de Riachão de Jacuípe, Amélia Rodrigues e, com a continuação das "quedas", verificou-se, posteriormente, o "recuo" para São Paulo e Rio de Janeiro, a alternativa mais viável naquele momento. Duas consequências decorrem dessas prisões: primeira, a vulnerabilidade do grupo se apresentou como fato indiscutível, e a clandestinidade tornou-se uma alternativa aceitável para o restante do grupo; segunda, a dispersão foi total, e os militantes buscaram apoio em outras organizações da esquerda armada, na rede de simpatizantes e entre os familiares. Face aos acontecimentos, durante o mês de outubro de 1969, a polícia prenderia Nemésio Garcia e Chantal Russi no município de São Miguel das Matas, onde se encontravam foragidos. ${ }^{19}$ Esse fato promoveria a desarticulação do grupo, a perda de contato entre alguns integrantes, obrigando-os, definitivamente, a afastarem-se de Salvador. No caso de Carlos

\footnotetext{
${ }^{18}$ Entrevistas com Juca Ferreira, José Carlos Souza, Rui Paterson; Jurema Valença. (Cf. A Tarde, 19, 21 e 25 fev. 1970). Ver também (BNM 192, 1971, p. 60-61; JOSÉ, Emiliano, 2000, p. 87).

${ }^{19}$ Entrevistas Carlos Sarno, Rui Paterson, Jurema Valença. (Cf. BNM 192, 1971, p. 59-60; Jornal da Bahia, 18 out. 1969)
} 
Sarno e Jurema Valença, a cidade escolhida para "recuo" fora São Paulo, ficando evidente a adesão à VAR-Palmares, senão apenas por afinidades políticas, também por questões de segurança. ${ }^{20}$ Paterson nos diz que "as prisões transformaram, aquele que seria um processo calmo de integração, com inúmeras discussões, em puro engajamento por necessidade de ajuda".

Essa Dissidência que se ligou à VAR-Palmares, operava em Salvador em quatro níveis bastante distintos: o Setor Estudantil Secundarista; o Estudantil Universitário; o Setor Operário e o Setor do Interior. A orientação de cada nível ficava sob a responsabilidade de um militante pertencente aos quadros de direção. O Setor Estudantil era coordenado por Jurema Valença e se subdividia em Secundarista e Universitário, este último englobava as Faculdades de Filosofia das Universidades Católica e Federal. Esse setor tinha como principal objetivo o recrutamento de novos militantes para a organização e a difusão do "marxismo". Entretanto, seguindo a linha teórica da sua organização de esquerda, de inserção nos movimentos de massas, o grupo, constantemente, participava de passeatas e reivindicações estudantis. A participação no Congresso da UNE em Ibiúna, interior de São Paulo, realizado clandestinamente em outubro de 1968, que contou com a presença de cerca de setecentos delegados estudantis de todo o país, segundo os entrevistados, foi importante pólo de recrutamento para a organização armada. ${ }^{21}$

Como atestou Jurema Valença, a Dissidência da qual ela foi dirigente, inicialmente, valorizara o "trabalho de bairro", embora tivesse realizado treinamentos militares, não o faziam com a perspectiva de realizar luta armada na Bahia e sim, com o objetivo de ingressar em grupos maiores de porte nacional para que pudessem ampliar a luta localizada em Salvador e em algumas cidades do interior do estado. Dessa forma, esse grupo evitou ações armadas em Salvador, considerando que o objetivo não era de uma resistência isolada, mas acordada com uma organização maior. Por conseguinte, o grupo se dedicara, sobremaneira, aos "trabalhos de massas". ${ }^{22}$

Essa mesma tendência da DI-BA possuía ainda um Grupo de Trabalho sediado no interior do estado, em Alagoinhas. O estreitamento das relações políticas com

\footnotetext{
${ }^{20}$ Em março de 1970, como resultado das prisōes de Getúlio Gouveia e Marie H. Russi e as conseqüentes desarticulações, Denílson Vasconcelos, até o momento militante do grupo de Carlos Sarno, entra para o MR-8 e fica sob a assistência de Maria Lúcia Murat; Israel Pinheiro viaja para o Rio de Janeiro e depois segue para Minas Gerais. Ver também depoimentos de Jurema Valença, Carlos Sarno, Israel Pinheiro, Rui Paterson.

${ }^{21}$ Jurema Valença Marie Hélène e Carlos Sarno participaram desse Congresso da UNE em Ibiúna. Entrevistas Carlos Sarno, Jurema Valença, Ubiratan Castro. (Cf. BNM 192, 1971, p. 58-60)

${ }^{22}$ Atividades de mobilização e organização popular: recrutamento de simpatizantes, estruturação de entidades estudantis, sindicais, greves e passeatas.
} 
essa cidade começou no início de 69, com uma série de Conferências realizadas no Tênis Clube de Alagoinhas e promovida por Wanderlan Macedo Bomfim, tendo como um dos conferencistas o professor Alberto Goulart Paes Filho, conceituado professor de História do Colégio Universitário da Bahia. A partir daí, a base da organização guerrilheira nessa cidade seria coordenadas pelas irmãs Chantal Russi e Marie Hélène Russi, em contato direto com Wanderlan Macedo Bonfim. ${ }^{23}$

Jurema Valença ainda acrescentou que a tentativa de recrutamento de militantes e simpatizantes nas fábricas dava-se através da distribuição de panfletos que tratavam de reivindicações salariais, trabalho esse desenvolvido, sobretudo sob a coordenação de Nemésio Garcia. O seu grupo buscou atuar principalmente nas indústrias metalúrgicas, consideradas as mais importantes da região, abrangida pelas cidades circunvizinhas de Salvador, onde se instalava a atividade industrial, a exemplo de Camaçari. Um fato marcante foi a tentativa de sublevação dos ferroviários da Leste Brasileira, para a qual foram realizadas pichaçóes e panfletagens na cidade de Alagoinhas. ${ }^{24}$

Tratando-se da VAR-Palmares, as bases desta no interior espalhavam-se pelas cidades de Cruz das Almas, Feira de Santana, Vitória da Conquista, além dos contatos herdados da DI-BA em Alagoinhas. Em Itabuna, houve uma tentativa de implantação, porém sem sucesso. Rui Paterson apontou um número de dez a doze cidades, nas quais essa organização teria simpatizante. ${ }^{25}$

Conhecemos a formação, no início do ano de 1969, de mais uma organização armada em Salvador, o PCBR, através da junção de um grupo de dissidentes do

PCB com um grupo de jovens oriundos do movimento estudantil secundarista de 1967 e 1968, sobretudo do Colégio de Aplicação de Salvador e estudantes secundaristas da cidade de Jequié. Em grande medida, também, por alunos da faculdade de Direito, Filosofia, Geologia e Economia da Universidade Federal da Bahia, todos sob a orientação de "quadros" do PCBR de Pernambuco, deslocados para organizar e estruturar a base de Salvador. ${ }^{26}$

\footnotetext{
${ }^{23}$ A base de Alagoinhas era composta por Wanderlan Macedo, Wanderley Macedo, Arnaldo Alves, Adolfo Costa, Raimundo Alves e Estela Santana. Entrevistas Carlos Sarno, Jurema Valença. (Cf. BNM 192, 1971, p. 33)

${ }^{24}$ Segundo depoimento de Jurema Valença, Nemésio Garcia trabalhava dentro de uma fábrica e Marie Russi era secretária de uma indústria do Pólo Petroquímico. (BNM 192, 1971, p. 14, 60, 64-65)

${ }^{25}$ Entrevista Amilcar Baiardi, Rui Paterson. (Cf. BNM 192, 1971, p. 60)

${ }^{26}$ Entrevistas Renato Affonso, Dirceu Ribeiro, Paulo Pontes. (Cf. BNM 212, 1970, p. 55, 82, 181-182, 829,1130; BNM 612, 1970, p. 494-495)
} 
Dirceu Régis Ribeiro, natural da cidade de Remanso, interior da Bahia, foi um importante "quadro" que veio para Salvador no início de 1969, com permissão da Direção Nacional para ampliação de novos contatos e dinamização das atividades do PCBR na cidade. Esse militante, ainda no Rio de Janeiro, foi ligado à Frente Unida de Estudantes do Calabouço (FUEC). Participou das mobilizações do restaurante do Calabouço e, posteriormente, incorporou-se ao PCBR que o reenviou para a Bahia. ${ }^{27}$

Após a chegada de Paulo Pontes a Salvador, vindo de Recife, em fevereiro de 1970, ocorreu uma reunião com a participação de Dirceu Régis, Frederico Menezes de Oliveira, Renato Ribeiro da Costa - os dois últimos do Comando Regional de Pernambuco - mais Getúlio Oliveira Cabral, Dirigente Nacional, na qual ficou estabelecida a tarefa de dinamizar as atividades do PCBR na capital baiana e ampliar os contatos já existentes da base estudantil, antigos colegas do Colégio "Central", que se reencontraram na Faculdade, geralmente, de Economia, e reuniram-se, novamente, para trabalharem juntos, como militantes do PCBR. ${ }^{28}$

O Comitê Regional do PCBR em Salvador estava constituído por Renato Ribeiro da Costa e Frederico José Menezes de Oliveira, membro do Comitê da Zona da Grande Recife. No entanto, na Bahia, a direção permanente do partido estava formada por Paulo Pontes da Silva, Dirceu Régis Ribeiro e Renato Ribeiro da Costa. De acordo com as fontes consultadas, o partido estava organizado em duas bases: uma estudantil, relativamente ampla, e outra operária, sob a assistência política de Dirceu Régis e, posteriormente, também de Paulo Pontes. Este último classificou a estrutura em "Frente de Massas" e "Frente Militar" e ambas, sistematicamente, separadas. ${ }^{29}$

No interior do estado, o reforço do PCBR vinha da cidade de Jequié. No final de 1968, chegaram do Rio de Janeiro, para aí fundar o partido, os mili-

\footnotetext{
${ }^{27}$ Entrevista Dirceu Ribeiro. (BNM 91, 1970, p. 108-112; BNM 612, 1970, p. 403-404)

${ }^{28}$ Verificamos que, apesar da base do PCBR pertencer a estabelecimentos de ensino diferentes das duas organizações guerrilheiras mencionadas anteriormente, porém a sua composição era, também, predominantemente de estudantes. Em grande medida esses militantes da base estudantil foram recrutados por Renato Affonso de Carvalho e Maria Lúcia Santana Cerqueira. (Cf. BNM 612/70, p. 201-202, 392-393); entrevistas com Paulo Pontes, Dirceu Ribeiro, Renato Affonso. (BNM 212, 1970, p. 63-64, 96, 829)

${ }^{29}$ É de observar que existiriam duas bases ligadas a Dirceu Regis Ribeiro e Paulo Pontes da Silva: uma, sob a coordenação de Renato Affonso, composto por Marco Antonio Affonso de Carvalho, Elzenóbio Wagner Pereira Coqueiro, Maria da Glória Midlej Silva, Regina Martins e Roberto Albergaria de Oliveira. Renato Affonso era a ligação desse grupo com Suzana Maranhão, uma das militantes que recuou do Rio de Janeiro para Salvador, pertencente ao Grupo Político Militar. A outra coordenada por Maria Lúcia Santana Cerqueira, era composto por Aldo da Silva Vieira, Manoel Barreto, Maria Célia Magalhães e Antonio Leopoldo Meira. (BNM 612, 1970, p. 75-77, 494); entrevistas com Paulo Pontes, Dirceu Ribeiro, Renato Affonso. (BNM 212, 1970, p. 62-70)
} 
tantes Dirceu Régis, Juarez Sena e Geraldo Jorge Sardinha. ${ }^{30}$ A base estudantil, originária dos grêmios do Colégio Comercial de Jequié e Instituto Educacional Régis Pacheco, era a principal força do PCBR na cidade. As atividades, em Jequié, concentraram-se em panfletagens e distribuiçôes de manifestos, bem como, realização de pichações por ocasião de datas significativas para o partido, para citar um exemplo, o "Primeiro de Maio" e "25 de Março". Os temas expostos nos muros da cidade eram: "Abaixo a ditadura", "Comida para o povo", "O povo está com fome". O panfleto intitulado Campanha nacional contra os crimes da ditadura foi distribuído na noite de 28 de fevereiro de 1970, numa ação conjunta, envolvendo o PCBR e o PC do B. ${ }^{31}$

Quanto à busca de militantes no ambiente operário, a Leste Brasileira foi um dos principais alvos do PCBR na Bahia, tendo em Paulo Pontes o principal responsável pelos contatos. Os levantamentos de empresas sediadas em Simões Filho, desenvolvidos por essa organização guerrilheira, sugerem a abertura de outras possibilidades de ação junto ao operariado baiano. ${ }^{32}$

Ainda falando sobre a formação das organizações armadas em Salvador, salientamos que o primeiro ensaio de união de parte da DI-BA com a Dissidência da Guanabara (DI-GB) remonta ao final do ano de 1968, quando chegaram a Salvador dirigentes importantes, com o objetivo de discutir a linha política da organização da Guanabara. Contudo, o ponto inicial da formalização da fusão das duas dissidências viria a se verificar em uma reunião, ocorrida no início de 1969, com o então Dirigente Nacional da DI-GB, Franklin de Souza Martins, responsável pela Frente de Trabalho Armado. ${ }^{33}$ A reunião teve também como um de seus objetivos sistematizar algumas teses, discutidas posteriormente na "Conferência" realizada em junho de 1969, na cidade de Dias D'Ávila. Conforme depoimentos, a concentração durou dois dias, nos quais se discutiram as definições políticas da organização, bem como a estruturação da

\footnotetext{
${ }^{30} \mathrm{O}$ grupo seria formado pelos acima citados e mais Ricardo César Sales da Nóbrega, Wesley Macedo de Almeida, Manoel Amorim de Souza, VÂNIA e AQUILES (CODINOMES). Segundo informações do processo 363/70, em junho de 1969, divergências políticas no interior do PCBR afastariam Juarez Sena e Geraldo Jorge Sardinha e ambos atuariam no PC do B nessa cidade. Dirceu Regis Ribeiro afirmou que ate a sua prisão Geraldo Jorge Sardinha pertencia ao PCBR, e que mesmo depois de transferido para Salvador, ainda voltaria algumas vezes a Jequié para reunir-se com seu grupo.

31 (BNM 91, 1970, p. 108; BNM 363, 1970, p. 13-16; BNM 612, 1970, p. 404).

32 (BNM 91, 1970, p. 119-120, 146; BNM 212, 1970, p. 1131; BNM 612, 1970, p. 407, 410).

${ }^{33}$ Teriam estado nesta reuniāo, Juca Ferreira, Sérgio L. Furtado, José Carlos Souza, Carlos M. Villanueva e Elisabete Rebello Correia Lima. Durante os anos de 1969 e 1971, os principais dirigentes nacionais do MR-8 estiveram em Salvador. São eles: Franklin Martins, César Queiroz Benjamim, Cláudio Cardoso de Campos, Carlos Alberto Muniz e João Lopes Salgado (JOSE, 2000); entrevistas Juca Ferreira, José Carlos Souza. (Cf. BNM 192, 1971, p. 550-551, 581)
} 
mesma. Estavam presentes, também, alguns representantes da DI-GB, cujo objetivo maior foi formalizar a coligação das duas dissidências. Nessa "Conferência” de integração com a DI-GB, decidiu-se que as bases da organização, em sua estrutura baiana, continuariam as mesmas, porém com orientação da Guanabara. A partir desse momento, iniciou-se uma constante troca de quadros dirigentes, a exemplo de Sérgio Furtado, que seguiu para o Rio de Janeiro, enquanto outros militantes seguiram trajetória inversa, vindo do Rio de Janeiro para Salvador. ${ }^{34}$ Jose Carlos Souza relatou sobre essa reunião em Dias D’ Ávila:

A nossa questão era como fazer a luta armada combinada com a luta de massas, e que não adiantava ter uma luta armada sem a luta de massas [...] uma vez passamos dois dias numa casa em Dias D'Ávila, todo mundo confinado lá, alta segurança, e conversando sobre as definiçôes da organização. A Dissidência da Guanabara conversou com a gente, e nós já tínhamos uma certa inclinação por eles. Nessa época veio aqui na Bahia para conversar com a gente o Franklin Martins, veio o José Roberto ${ }^{35}$ esses dois vieram e então começamos cada vez mais a estreitar os laços com a Dissidência Comunista da Guanabara.

Juca Ferreira, desde o momento de estruturação do MR-8 em Salvador, foi o seu principal assistente. Era a pessoa de ligação entre a Direção Regional (Maria Lúcia Murat de Vasconcelos) e a Direção Nacional no Rio de Janeiro, dito de outra maneira, Juca Ferreira era o responsável por orientar as dirigentes que aqui atuavam. Lúcia Murat, ${ }^{36}$ militante do MR-8 na Guanabara, pertencia ao grupo de Ação e Propaganda, que integrava a Unidade Interna da Frente Operária chegou a Salvador em fevereiro de 1970, junto com Marcos

\footnotetext{
${ }^{34}$ Nessa reunião, também se decidiu sobre o início da atuação da organização no meio operário, porque, até esse momento, a predominância da mesma era no setor estudantil. Entrevistas Juca Ferreira, José Carlos Souza. (BNM 192, 1971, p. 581,1473)

${ }^{35}$ Provavelmente José Roberto Spiegel.

${ }^{36}$ Segundo informaçôes contidas no livro de Luiz Maklouf Carvalho (1998) e do relatório do processo (BNM 192, 1971, p. 431-432), Lúcia Murat pediu afastamento da linha de tiro da organização após algumas falhas pontuais nas ações armadas no Rio de Janeiro. Foi, então, deslocada para Salvador, atuou na mais rigorosa clandestinidade, fazendo contatos, inclusive, com outras organizações armadas em atuação na cidade. Voltou para o Rio de Janeiro no começo de 1971 e, presa no dia 31 de março desse mesmo ano. A ex-militante, hoje, é cineasta e dirigiu os filmes, Doces Poderes e Que Bom Te ver Viva, este último, um sensível documentário sobre mulheres torturadas pela ditadura.
} 
Dantas Loureiro. ${ }^{37}$ Com a reestruturação acontecida após o sequestro do embaixador norte-americano, a militante recebeu como tarefa o recrutamento de simpatizantes para a militância da organização, mas a sua tarefa principal na Bahia foi a de coordenar e reorganizar as atividades do MR-8, pois teria encontrado "a organização em Salvador sem nenhuma atividade, com quase todos os membros 'entocados'em aparelhos"38.

A presença de Lúcia Maria Murat em Salvador teria definido estruturalmente o MR-8, dividindo-o, basicamente, em quatro frentes: Frente de Trabalho Interno que atuava nos bairros populares, com levantamento de questionário socioeconômico, proteção do arquivo, coleta de noticias da imprensa local, construção de artigos e distribuição do periódico Avante; Frente de Trabalho Externo, Frente Operária e Frente Estudantil. ${ }^{39}$ Contudo, na prática, nem todas as quatro "frentes" funcionaram satisfatoriamente, apenas a Frente Estudantil e a Frente Operária se destacaram. Encontramos ainda nos relatórios pesquisados, informaçóes confirmadas em alguns depoimentos, que o processo de estruturação do MR-8 em Salvador também contou com o Setor de $\mathrm{Campo}^{40}$ e o Setor de Camadas Médias (Imprensa, Estudantil, Pesquisa e Inteligência, Trabalho de Bairros). ${ }^{41}$

Em 15 de julho de 1970, por determinação de Carlos Alberto Vieira Muniz, então dirigente do MR-8 no Rio de Janeiro, Eliana Gomes de Oliveira chega a Salvador para coordenar o Setor de Camadas Médias, dando assistên-

\footnotetext{
${ }^{37}$ Alguns dias após a chegada da Lúcia Murat, também comparece a Salvador o dirigente nacional, Carlos Alberto Muniz, trazendo Cr\$2.000,00 para a organização e seria a principal ligação com Lúcia Murat e a Direção no Rio de Janeiro em determinado momento. Sérgio Landulfo Furtado foi citado como importante dirigente. Juca Ferreira, preso em outubro de 1970, após ser libertado, provavelmente em dezembro desse mesmo ano, passa para a clandestinidade. (BNM 192, 1971, p. 90-91,169, 418)

${ }^{38} \mathrm{O}$ termo "aparelho" refere-se às casas e apartamentos utilizados pelas organizaçóes clandestinas de esquerda para abrigar seus militantes, guardar documentos, bem como realizar reuniōes.

${ }^{39}$ A Frente de Trabalho Interno ligado ao Setor de Camadas Médias estaria sob a responsabilidade de Denílson Vasconcelos, juntamente com Diogo Assunção Santana, Milton Mendes Filho e Jaileno Silva. O MR-8 em documento “Orientação para a prática” de janeiro de 1971, parte VI define como objetivo do Trabalho Interno desenvolver a agitação e a propaganda em áreas consideradas importantes, de forma clandestina, por pequenos grupos de ação através de pichações, panfletagens etc. Frente de Trabalho Externo, ligada ao Setor Operário encarregado de fazer pichação, panfletagem e levantamento de bairro, estava composta por Luis Antonio Santa Bárbara, Airton da Silva Ferreira Filho, José Carlos Souza.

${ }^{40}$ O Setor de Campo estaria composto pelos seguintes militantes: Luis Antonio Santa Bárbara, José Carlos Souza, Olderico Campos Barreto, José Campos Barreto, Otoniel Campos Barreto, Félix Escobar, sob a coordenação de João Lopes Salgado.

${ }^{41}$ O Setor de Camadas Médias teria sido formado pelos militantes: João Luis da Silva Ferreira, Maria Lúcia Santana Cerqueira, Denílson Ferreira de Vasconcelos, Renato José Amorim da Silveira e Sergio Landulfo Furtado sob a coordenação de Eliana Gomes de Oliveira. (Cf. BNM 52, 1971, p. 57-59; BNM 192, 1971, p. 19, 35-36, 89-91, 170, 190, 192, 423-428, 580-582, 1479); entrevistas Renato Amorim da Silveira, Juca Ferreira, José Carlos Souza.
} 
cia ao movimento estudantil, a simpatizantes, e fornecendo infra-estrutura de imprensa, documentação, montagem de aparelhos, compra de veículos, assistência financeira, médica, odontológica, pesquisa e serviços de inteligência. ${ }^{42}$

O organismo de Logística do Setor de Camadas Médias era coordenado por Eliana Gomes de Oliveira e Juca Ferreira, que respondiam pelos recrutamentos e assistência de estudantes e profissionais liberais, através da formação de grupos de estudos, infra-estrutura (montagem de "aparelhos", assistência financeira, médica e dentária, remédios, depósito de material), circulação de documentação falsa e o trabalho de imprensa. Uma das atividades do trabalho de imprensa era a confecção dos periódicos Venceremos, Avante e Bandeira Vermelha. ${ }^{43}$

Em termos de trabalho nos bairros, o setor do MR-8 objetivava a sua ampliação, com a preparação e interação nas cidades, cuja importância tática era descrita em seus documentos de discussão interna. A cidade daria apoio futuro à área principal da organização armada, definida, estrategicamente, pela área rural. A formação de Grupos de Ação nos bairros, cujo objetivo principal era o de sustentar o trabalho de campo, consistia em tentar motivar a população com as ideias da organização, concentrando-se sobretudo nas camadas menos favorecidas economicamente dos bairros da Caixa D’Água, Alagados, dentre outros. ${ }^{44}$

Pedro Juracy Damasceno Ferraz, em seu depoimento, revela que o trabalho nos bairros consistia no levantamento de

pesquisa em fontes de abastecimento, como mercados, mercearias, farmácias, consultórios ou postos médicos e dentários, oficinas, serviço de coleta, galerias de águas pluviais, bem como nas empresas de transportes coletivos.

O grupo dos trabalhos de bairros também preparava a confecção dos três periódicos acima mencionados e entregava-os ao grupo da Frente de Trabalho

\footnotetext{
${ }^{42}$ Entrevistas Renato Amorim da Silveira, Juca Ferreira. (BNM 192, 1971, p. 89-91)

${ }^{43}$ Esse material de informação das organizaçōes de esquerda baianas, ora é denominado, no processo e nas entrevistas, como panfletos, ora como jornais. Como não tivemos acesso a essas publicações, não conhecemos o seu tamanho e conteúdo para classificá-los e, a partir daqui, os denominaremos periódicos. Esclarecemos ainda que o Setor de Imprensa estaria sob a responsabilidade de Eliana Gomes de Oliveira, o Setor de Pesquisa e Inteligência com Renato da Silveira e o Setor de Movimento Estudantil com Maria Lúcia Santana Cerqueira, que após as prisões e desestruturações do PCBR passou a atuar no MR-8. Ver entrevistas Renato Amorim da Silveira, Juca Ferreira em (BNM 192, 1971, p. 90, 427-428)

${ }^{44}$ Lúcia Murat atuava diretamente no Setor de Trabalho de Bairro dando assistência aos trabalhos nos bairros empobrecidos da cidade, que eram coordenados por Denílson Ferreira de Vasconcelos. Pertenciam a esse grupo Milton Mendes, Jaileno Sampaio Silva, Carlos Vilanueva, Diogo Assunção de Santana e Elisabete Rebello Correia Lima. (BNM 192, 1971, p. 45)
} 
Interno para distribuí-los nas atividades de panfletagens, pichações noturnas e levantamentos sobre a vida da população nos bairros. ${ }^{45}$

O trabalho de pesquisa e serviço de inteligência desenvolvido por Renato da Silveira, sob a assistência de Juca Ferreira, destacava-se pelo levantamento socioeconômico do estado e de informação e contrainformação. As atividades desse setor incluíam a classificação de recortes de revistas brasileiras e estrangeiras contendo notícias econômicas e políticas e um especial esquema de pesquisa sobre a realidade baiana, entretanto, muito cedo, revelar-se-iam irrealizáveis devido a dificuldades práticas. ${ }^{46}$

Pode-se dizer que, em tese, os setores das organizações não se confundiam, os militantes buscavam seguir medidas de segurança que exigiam uma rígida separação entre eles, restringindo a apenas uma pessoa de cada setor, o contato com a direção regional e, da mesma forma com relação à representação frente à direção nacional. Era a chamada "estanquização", lembrada pelos depoentes. ${ }^{47}$

A cidade de Feira de Santana foi a principal base do MR-8, além da capital baiana. ${ }^{48}$ Contudo, em virtude de serem iniciantes, não houve nenhum trabalho prático naquela cidade, apenas a realização frequente de discussões teóricas. Os levantamentos cartográficos e mapas de estradas de cidades como Feira de Santana, Vitória da Conquista, regiôes do baixo e médio São Francisco e nordeste do estado indicam um esforço da organização em ampliar suas bases no interior. ${ }^{49}$

Em geral, no plano de atuação política com os operários, as organizações armadas tentaram estabelecer contatos para a realização de um trabalho de

\footnotetext{
${ }^{45}$ Entrevistas Renato Amorim da Silveira, Juca Ferreira. (BNM 192, 1971, p. 11-40, 130-132, 428)

${ }^{46}$ Entrevista Renato Amorim da Silveira. (BNM 192, 1971, p. 91-120)

${ }^{47}$ Essa questão foi levantada por Juca Ferreira, José Carlos Souza, Paulo Pontes, Dirceu Régis, Jurema Valença, entre outros.

${ }^{48}$ Em Feira de Santana o MR-8 teria interação com os diversos grupos organizados no meio estudantil, PC do B, AP, POC, MOLIPO e PCBR. Vale um estudo sobre o MR-8 em Feira de Santana para verificar o teor das atividades. Ver: Cerqueira (2002, p. 49, 69, 74, 109). O grupo em Feira de Santana, sob a assistência de Carlos Moreira Villanueva era formado por: Luis Antonio Santa Bárbara (antes de ir para a Frente de Trabalho externo e posteriormente o Setor de Campo), José Carlos Santa Bárbara (este posteriormente afasta-se da organização), Carlos Orleans, Lamartine Mota, Antonio Rocha Martinez Fernandez, Vera Gomes, Josafá Costa Miranda, Evan Felipe de Souza, Milton Mendes (antes de integrar em Salvador a Frente de Trabalho Interno) e Antonio de Freitas, este último exerceria função de apoio na ação do seqüestro do embaixador norte-americano Charles Elbrick. Temos conhecimento de outros militantes desse grupo, mas por meio de codinome, optamos em não inseri-los. Ver também depoimentos de Juca Ferreira e Renato da Silveira.

${ }^{49} \mathrm{O}$ militante responsável pelos trabalhos da organização no Recôncavo Baiano foi César Queiroz Benjamim (CERQUEIRA, 2002; PATARRA, 1992, p. 478); entrevistas com Juca Ferreira, José Carlos Souza, Renato Amorim Silveira. (BNM 192, 1971, p. 99-101, 189-190, 580-581, 598-600)
} 
"agitação e propaganda", baseado na atividade de panfletagem e busca de contatos em algumas indústrias sediadas em Salvador. Em relação ao MR-8, além das afirmações de alguns depoentes, foi encontrado em um dos "aparelhos" em apreensão realizada pelos órgãos de segurança e, por estes, atribuídas ao MR-8 - levantamentos de fábricas no município de Lauro de Freitas, região metropolitana de Salvador e indústrias têxteis, metalúrgicas, siderúrgicas e químicas do estado da Bahia. O principal contato operário do MR-8 acontecia por meio de um simpatizante, mecânico industrial, chefe de uma seção na Fábrica Nacional de Vagóes, localizada nesta capital, o qual se dispunha a contribuir com dinheiro e facilitação de empregos para membros da organização. ${ }^{50}$

Os periódicos Resistência Estudantil, Luta Operária e Luta Camponesa podem ser apontados como veículos de "agitação e propaganda" do PCBR em Salvador, no sentido de divulgar propostas de oposição à ditadura para a população baiana. Contudo, não foi possível obter informações mais específicas sobre esses meios de comunicação, apenas que seriam publicações "precárias" e que eram impressos e distribuídos com dificuldade. Numa das açôes mais mencionadas nos depoimentos, ocorrida em maio de 1969, o PCBR fecharia os principais acessos à estação de transporte urbano da Barroquinha com militantes armados, para fazer propaganda revolucionária através da distribuição de panfletos e realização de "comício relâmpago". ${ }^{51}$ Para uma melhor visualização dessa panfletagem do PCBR, exemplificamos o relato de Renato Affonso:

Nós fizemos inúmeras panfletagens e pichaçōes, todas elas armadas, porque a orientação era essa, [...] fizemos um certo trabalho que não teve repercussão, era um trabalho mais consistente de assistência política em bairros populares. Nós éramos de uma história de vínculo com o movimento, nunca fomos muito submissos àquela orientação que vinha da direção, que tinha um traço vanguardista muito acentuado. Nós lutamos por preservar um vínculo com o movimento, um vínculo com a massa, nós fazíamos trabalho de formação em diversos bairros populares.

\footnotetext{
${ }^{50}$ Jose Carlos Souza afirmou em depoimento uma tentativa sem sucesso, de inserção do MR-8 entre os operários, através de Carlos Moreira Villanueva. (BNM 192, 1971, p. 64, 99-101).

${ }^{51}$ Nessa panfletagem, estavam presentes, Renato Affonso de Carvalho, Marco Antonio Afonso de Carvalho, Regina Martins da Matta e Maria da Glória Midlej Silva; Outras panfletagens ainda ocorreriam até o início de 1970 nas faculdades de Engenharia, Direito e Filosofia da UFBA, próximo a Igreja de São Bento e nas praias de Salvador, dentre elas, a da Ribeira. (BNM 212, 1970, p. 6, 34, 54-55, 83-84, 96, 241; entrevistas Paulo Pontes, Renato Affonso e Dirceu Ribeiro. (BNM 612, 1970, p. 494-497)
} 
Eu, pessoalmente, assistia a vários e vários [sic] desses trabalhos de formação política e teórica, e de tentativa de procurar, organicamente, setores mais destacados de determinados bairros populares, e tentar, depois, dar um desdobramento mais partidário. Mas isso chocava com uma preocupação maior que acabou prevalecendo, de ações de vanguarda [...] também fizemos algumas panfletagens até bonitas do ponto de vista estético, vestidos a caráter, de boina [...] fechamos uma vez os três lados da Barroquinha, a saída para a Praça dos Veteranos, a saída para cima e a saída para a ladeira do Paraíso, colocamos três ou quatro companheiros em cada saída dessa e, enquanto os outros companheiros faziam a panfletagem de mão em mão, no Primeiro de Maio, inclusive a repressão apareceu, houve um início de tiroteio, mas eles fugiram por que nós éramos um número muito maior, mas somente um, dois ou três estavam armados.

Levando em conta os depoimentos de Renato Affonso de Carvalho e Paulo Pontes, percebemos que o PCBR vivenciou uma divergência interna no que se refere ao teor da atividade a ser desenvolvida. $\mathrm{O}$ grupo que se formou em Salvador teria uma posição de resistência centrada nos trabalhos políticos de recrutamento, sobretudo nas áreas estudantil e operária, uma tendência diametralmente oposta à defendida pelos militantes que chegaram do Rio de Janeiro, sobretudo representados por Prestes de Paula e Bruno Maranhão. Por ocasião das comemorações do "Primeiro de Maio" de 1970, estas duas tendências teriam se debatido quanto à importância de uma ação panfletária. Entretanto, nessa data, recebendo autorização do comando nacional, Paulo Pontes, Dirceu Régis Ribeiro, Natur de Assis Filho e Wellinghton Araújo de Freitas imprimiram e distribuíram, na madrugada anterior ao dia primeiro de maio de 1970, cerca de dois mil panfletos com as seguintes palavras de ordem: "Primeiro de Maio, dia de luta", além de pichações nos bairros de IAPI, Pau Miúdo e Liberdade. ${ }^{52}$

Neste depoimento, Paulo Pontes também aponta as diferenças no interior do PCBR:

Eu insistia muito que o fundamental aqui era ação política

\footnotetext{
52 Renato Affonso de Carvalho, Marco Antonio Affonso de Carvalho, Regina Martins, Maria da Gloria Midlej, Wagner Coqueiro e JOÃO (CODINOME), também fariam panfletagens e pichaçōes em comemoração ao primeiro de maio de 1970 no bairro do Pau Miúdo. Entrevistas: Paulo Pontes e Dirceu Ribeiro (BNM 91, 1970, p. 23-26, 109,$111 ; 212 / 70$, p. 1128-1130; BNM 612, 1970, p. 876).
} 
e não ação armada, se é que poderia fazer essa diferença, ou seja, quando se fazia uma ação política, ia armado, sim, mas para resistir [...] esse pessoal que estava aqui era mais militarista, eles chegavam e diziam: "a grande propaganda é se fazer uma ação armada de expropriação de banco".

A rigor, a organização que efetivamente realizou ações armadas em Salvador foi o PCBR, apresentando uma inclinação mais "militarista" que as outras organizações, no período em que parte da direção nacional vivia em Salvador, não obstante a perspectiva orientada por Dirceu Régis e Paulo Pontes, visava, ao contrário, uma política voltada para o recrutamento de estudantes, através de atividades de panfletagem e pichação e ações de "agitação e propaganda", que visavam sua expansão.

As redes de simpatizantes, ou seja, colaboradores vinculados à coordenação dos setores e à direção regional, também foram extensas nas organizaçōes baianas. A esse respeito, foi reveladora a constância da utilização, pelas organizaçôes armadas, dos serviços de seus simpatizantes. Para alguns, a hospedagem temporária de militantes, a função de guardar documentos pessoais falsificados, documentos políticos para discussão interna e mimeógrafos; atendimento médico-odontológico gratuito; para outros, a tarefa de "cobrir pontos" ${ }^{3}$, distribuir panfletos e contribuição em dinheiro e empréstimo de automóveis. ${ }^{54} \mathrm{O}$ MR-8, por exemplo, teria tido como colaboradores, o chefe de seção da Fábrica Nacional de Vagóes que facilitou a admissão de seus militantes nesse estabelecimento industrial, e um funcionário da Polícia Federal, pai de um militante da organização, quem teria avisado ao filho sobre a prisão de Solange Gomes, militante que desencadeou uma série de quedas no MR-8, iniciadas em março de 1971.55

\section{Algumas considerações finais}

Não obstante, as organizações por nós pesquisadas insistissem que o local primordial da luta seria o campo, na Bahia, assim como em outros estados, as organizaçôes foram desarticuladas antes que pudessem aprofundar qualquer trabalho no campo. A inserção dos grupos armados na área rural foi praticamente

\footnotetext{
${ }^{53}$ Termo utilizado na época referente ao encontro clandestino.

${ }^{54}$ O MR-8 teria tido um simpatizante médico e outro dentista que prestavam atendimento aos militantes, gratuitamente em seus consultório. Ver (BNM 192, 1971 p. 64, 92, 172); Depoimento de Renato da Silveira e Juca Ferreira.

${ }^{55}$ Ver (BNM 192, 1971, p. 63-64, 146-147, 220-221, 346; JOSE, 2000).
} 
nula, tanto na organização dos trabalhadores rurais, quanto na efetiva implantação de uma base guerrilheira. Contudo, no final de 1970, o MR-8 deslocou quadros para o interior do Estado. Em Alagoinhas, sob a coordenação de José Carlos Souza e Félix Escobar, estavam os irmãos Wanderlan e Wanderley Macedo Bomfim dentre outros; na região do Buriti Cristalino, município de Brotas de Macaúbas, havia um outro grupo sob a coordenação de João Lopes Salgado. ${ }^{56}$

Entendemos que a prática de militantes procurados transitarem entre os estados, deveria ser uma atitude natural nas situaçôes de perigo vivida na época em estudo. ${ }^{57}$ Para Ferreira, também é importante perceber que a não realização de ações armadas em Salvador foi muito mais o resultado da percepção da fragilidade orgânica do seu grupo e da efetivação do trabalho político em açôes de propaganda:

Não era bem a noção de recuo, era mais o entendimento de que nós éramos frágeis, como estrutura clandestina, tínhamos saído recentemente do movimento de massas e todos nós havíamos participado dos movimentos de massa aqui na Bahia, desde 1966 até 1968, onde estávamos expostos. $^{58}$

A rigor, o PCBR não teria considerado o princípio da preservação de Salvador e, com a chegada de parte da Direção Nacional, vira-se com a necessidade de "levantar fundos" para organizar a estrutura e viabilizar o sequestro do cônsul norte-americano em Salvador, Alexander F. Watson, ação revolucionária que teria como objetivo a troca do seqüestrado pela liberdade de mem-

\footnotetext{
${ }^{56}$ A “área de campo", na cidade de Brotas de Macaúbas, teria sido preparada por João Lopes Salgado, dirigente nacional e coordenador do setor de campo da organização, e Luis Antonio Santa Bárbara, em busca de condições propícias de segurança para aguardar a chegada de Carlos Lamarca. Lúcia Murat teria comunicado a José Carlos Souza que o PCBR iria executar a ação de seqüestro do cônsul norte-americano, motivo que anteciparia a sua ida para o setor de campo, a partir de junho de 1970. (JOSE, 2000; RIDENTI, 1993), entrevistas com Paulo Pontes e José Carlos Souza. (BNM 52, 1971, p. 57-62, 547; BNM 192, 1971, p. 64-66, 424, 581-583, 599-600)

${ }^{57}$ Na perspectiva de trocas de quadros e "recuo", vieram para Salvador César Queiroz Benjamim, João Lopes Salgado, Felix Escobar. Ver entrevista de José Carlos Souza, Juca Ferreira.

${ }^{58}$ Juca Ferreira, em entrevista, confirmou que os militantes do MR-8, Sérgio Furtado, Elisabeth Rebelo Correia Lima e Maria Lúcia Cerqueira Santana recuaram para o Rio de Janeiro, além de outro militante da base de Feira de Santana, que teria sido o "caseiro" do local em que o embaixador dos Estados Unidos, hospedou-se durante o seqüestro em setembro de 1969. Juca Ferreira, preso em outubro de 1970, foi solto em dezembro desse mesmo ano, com a obrigação de comparecer toda quinta-feira á sede da Polícia Federal para assinar o ponto, visto que a polícia havia acreditado que o militante procurado era seu irmão, Júlio Ferreira. Com a prisão de um militante da base de Feira de Santana e a conseqüente colaboração deste, confirmam-se as suspeitas da polícia em relação a Juca que, na iminência de ser preso, segue rapidamente para o Rio de Janeiro. Alguns meses depois, com a prisão de um militante nesta cidade, a polícia teria tido a certeza da participação de Juca Ferreira no MR-8.
} 
bros da organização presos no início de janeiro em São Paulo, dentre os quais, os dirigentes nacionais Apolônio de Carvalho, Jacob Gorender e Mário Alves. Segundo Paulo Pontes, então dirigente regional, chegaria a Salvador, por volta do mês de março de 1970, uma média de doze importantes militantes para um recolhimento provisório e posteriormente serem redistribuídos em outros estados, onde houvesse atuação do PCBR..$^{59}$ Paulo Pontes apontou que, no entendimento do PCBR na época, a guerra acontecia em todo o país, portanto, não existiria área neutra.

Todavia, esse mesmo militante, juntamente com Dirceu Régis e Renato Ribeiro da Costa entraria em desacordo com o setor "militarista" por considerarem prematura a "ação de expropriação" ${ }^{60}$, realizada em 25 de maio de 1970, no Banco da Bahia, situado á avenida Lima e Silva, na Liberdade. Na ocasião, Paulo Pontes fora recrutado pelo Comando Político Militar da organização e terminou por participar dessa ação, em respeito à posição da Direção Nacional que se mostrara intransigente. Esse seria o único assalto que se tem notícia, realizado por uma organização de esquerda armada em Salvador. ${ }^{61}$

Acreditamos que através da história da VAR-Palmares, do PCBR e do MR-8 em Salvador, esta cidade não pode ser considerada como "área de recuo" apenas. Não podemos negar que a resistência tenha ocorrido e a sua prática, assumido características diversas. O Rio de Janeiro e São Paulo foram "cidades recuos" para alguns militantes que saíram da Bahia, numa dinâmica de troca de quadros por motivos de falta de segurança.

\footnotetext{
${ }^{59}$ Identificamos os seguintes quadros do PCBR que chegaram para Salvador recuados do Rio de Janeiro: Bruno Maranhão (dirigente nacional), Suzana Maranhão, Fernando Augusto da Fonseca (Comando Político-Militar), Antonio Prestes De Paula (Comando Político-Militar), Getúlio de Oliveira Cabral (dirigente nacional), José Adeildo e mais MARIANA, BETO E ARNALDO (CODINOMES), também do Comando Político Militar. Essas pessoas foram consideradas nos depoimentos como o "grupo militarista". Ver BNM 612 (1970, p. 97, 109-110, 393-394, 497-498). Também citados nos depoimentos de Paulo Pontes, Prestes de Paula, Renato Affonso e Dirceu Régis, nas datas já mencionadas.

${ }^{60}$ Vale ressaltar que assalto a banco era uma das maneiras das organizaçōes adquirirem dinheiro para financiamento das suas estruturas, como aparelhos, armas, muniçôes, viagens, entras outras necessidades.

${ }^{61}$ Fizeram-se presentes nessa operação, os militantes: Antonio Prestes de Paula - comandante da operação e motorista da Aero-Willys de cor verde, placa "fria" 20.034/Ba, confiscada, anteriormente, na estrada Salvador-Feira de Santanae mais Paulo Pontes da Silva, Theodomiro Romeiro dos Santos, Valdir Sabóia, Fernando Augusto da Fonseca e Alberto Vinícius (não se sabe o sobrenome). No carro de apoio, um Volkswagem vermelho, placa "fria" 1050 de Sergipe, que estava estacionado nas proximidades do banco, estariam Bruno Maranhão, José Adeildo e Getúlio Oliveira Cabral. No resultado da pesquisa desenvolvida por Carlos Fico (2001, p. 231) a Bahia apareceu com dois bancos assaltados. Também Ruy Cerqueira (2002, p. 92) relata que Luiz Antonio Santa Bárbara teria comandado uma operação de assalto a banco, provavelmente ao final de agosto de 1970, no bairro do Canela, em Salvador, e conclui que o episódio deste assalto nunca foi bem esclarecido (BNM 91, 1970, p. 109-110; BNM 612, 1970, p. 71-82, 203; GORENDER, 1994; JOSE, 2000) entrevistas com Paulo Pontes, Dirceu Ribeiro, Antonio Prestes de Paula. (Cf. A Tarde, 6 jun. 1970, p. 14).
} 


\section{REFERÊNCIAS}

ALVES, Maria Helena. M. Estado e oposição no Brasil (1964-1984). 3. ed. Petrópolis, RJ: Vozes, 1987.

BOBBIO, Norberto. Direita e esquerda: razôes e significados de uma distinção política, São Paulo: UNESP, 1995.

CERQUEIRA, Ruy. Santa Bárbara: o estudante da Guerrilha: a vida e a trajetória política de único estudante de Feira de Santana que se tornou guerrilheiro. Feira de Santana: Gráfica Modelo, 2002.

D’ ARAÚJO, Maria Celina et al. Os anos de chumbo: a memória militar sobre a repressão. Rio de Janeiro: Relume-Dumará, 1994.

FICO, Carlos. Como eles agiam: os subterrâneos da Ditadura Militar: espionagem e polícia política. Rio de Janeiro; São Paulo: Record, 2001.

GORENDER, Jacob. Combate nas trevas: a esquerda brasileira: das ilusões perdidas à luta armada. São Paulo: Ática, 1990.

JOSE, Emiliano. Galeria F: lembranças do mar Cinzento. São Paulo: Casa Amarela, 2000.

PATARRA, J. L. Iara: reportagem biográfica. 3. ed. Rio de Janeiro: Rosa dos Tempos, 1992.

RIDENTI, Marcelo Siqueira. Em busca do povo brasileiro. Rio de Janeiro: Record, 2000.

WESCHLER, Lawrence. Um milagre, um universo: o acerto de contas com os torturadores. Companhia das Letras, 1990.

\section{ENTREVISTADOS}

\section{VAR-Palmares:}

Amílcar Baiardi, realizada em 16/08/2002.

Carlos José Sarno, realizada em 29/09/01 e 26/03/2002.

Israel Oliveira Pinheiro, 31/03/2000.

Jurema Ribeiro Valença, 28/07/2001.

Rui Pinto Paterson, 08/06/2002.

Ubiratan Castro de Araújo, 29/09/00 e 04/10/2000.

\section{PCBR:}

Antonio Prestes de Paula, 10/08/2001 e 04/08/2001.

Dirceu Régis Ribeiro, 06/07/2001.

Paulo Pontes da Silva, 28/08/1999 e 08/04/2000. 
Renato Jose Affonso de Carvalho, 22/06/1999.

MR-8:

João Luis da Silva Ferreira (Juca Ferreira), 18/04/2002 e 31/05/2002.

João José Reis, 27/04/2001.

José Carlos Souza, 16/11/2001.

Pedro Juracy Damasceno, 28/03/2002.

Renato Amorim da Silveira, 19/03/2002. 


\section{8}

\section{Notas sobre a história da Ação Popular na Bahia (1962-1973)}

Cristiane Soares de Santana ${ }^{1}$

A Juventude Universitária Católica foi criada em 1930, como parte da Ação Católica Brasileira. Em seus princípios era um movimento conservador e clerical que tinha como objetivo influenciar o sistema educacional brasileiro, promovendo a cristianização de uma futura elite intelectual que estava se formando nas universidades. Porém, essas preocupaçōes estritamente religiosas iriam se transformar numa postura mais crítica exigida pelo contexto social, econômico e político do país. A partir do final dos anos 50, os militantes da JUC começariam a perceber que a cristianização dos indivíduos não era suficiente para a transformação da sociedade brasileira, pois a defesa dos seres humanos e sua cristianização exigiam deles um engajamento no meio.

Diante dos problemas da realidade brasileira, os militantes da JUC iam percebendo as limitações do seu campo de atuação. Com isso, acabou surgindo a necessidade de participação em um movimento diretamente político, já que na JUC o espaço para a prática política era muito restrito.

A partir de 1960 notamos a presença cada vez maior dos militantes jucistas no meio estudantil. Neste mesmo ano, a JUC apoiou o baiano Oliveira Guanais, candidato da esquerda para a presidência da União Nacional dos Estudantes

\footnotetext{
${ }^{1}$ Mestre em História Social do Brasil pela Universidade Federal da Bahia.
} 
(UNE). Sua gestão, segundo Lima e Arantes (1984) ajudou a ligar mais a UNE às bases e a mobilizar os estudantes para a discussão dos seus problemas. De modo que, foram organizados encontros para debater os problemas regionais, tais como o I Seminário Nacional de Reforma Universitária, realizado na Bahia.

Em 1961, foi eleito para a presidência da UNE Aldo Arantes, que era militante da JUC e presidente do Diretório Central dos Estudantes (DCE) da Pontifícia Universidade Católica do Rio de Janeiro (PUC-RJ), tendo sua chapa composta por membros da União da Juventude Comunista. Além da presença na entidade representativa dos estudantes, a JUC estaria envolvida em importantes episódios da política nacional e estudantil, como a campanha pela legalidade, liderada por Leonel Brizola; a campanha pela reforma universitária, que desembocou na chamada greve de 1/3; a organização da UNE-Volante, que percorreu praticamente todas as capitais do país organizando o movimento estudantil. As atividades dos militantes da JUC não se restringiam ao meio universitário, pois eles atuaram em programas de educação popular, tais como o Movimento de Educação de Base, as Ligas Camponesas, o Centro Popular de Cultura etc. (LIMA; ARANTES, 1984).

A eleição de Aldo Arantes desencadeou atritos com a hierarquia eclesiástica. D. Jaime, prevendo os desdobramentos dessa politização extrema dos militantes, pediu que Aldo escolhesse entre a presidência da UNE e a militância na JUC. Ele escolheu a primeira opção e acabou sendo expulso da JUC. Assim, com o início de um conflito declarado com a Igreja Católica, surgiu a necessidade de outro instrumento de ação política que fosse capaz de responder às questôes colocadas pela realidade social, econômica e política. Isto fez com que setores da JUC passassem a buscar a criação de outra organização dando início ao processo de formação da Ação Popular.

A Ação Popular formou-se após três reuniōes. O primeiro encontro ocorreu em São Paulo, em 1962. Na primeira reunião, foi aprovado um documento chamado Esboço Ideológico que defendia o socialismo e a revolução brasileira. O nome do escolhido foi Grupo de Ação Popular (GAP), mas o surgimento pouco tempo depois de um agrupamento fascista chamado Grupo de Ação Patriótica (GAP) fez com que essa sigla fosse abandonada e o movimento passasse a ser chamado de "grupão" antes de receber o nome de Ação Popular. (SOUZA, L., 1984)

A segunda reunião de fundação da Ação Popular foi realizada em Belo Horizonte, em 1962, quando ficou estabelecido que o novo nome seria Ação Popular (AP). A última reunião ocorreu em fevereiro de 1963, em Salvador, onde ocorreu o I Congresso da Ação Popular e foi aprovado o seu Documento - 
Base que expressava em sua introdução a marca do humanismo cristão e do socialismo revolucionário, o qual seria o guia teórico do restante do documento.

A Ação Popular nesse período ainda possuía uma noção imatura de como se organizar o processo revolucionário. Mesmo assim, a organização queria disputar com as outras a hegemonia da revolução brasileira e sabia que para preparar a revolução era necessária a formação de um partido de vanguarda que organizasse as massas. Porém, como era uma organização basicamente estudantil, a AP passou a se preocupar em ampliar suas bases nos movimentos operários e camponeses. O Brasil vivia um contexto marcado por uma ascensão das classes populares, o que apontava a importância de um trabalho da organização no campo e na fábrica.

A AP iniciou um trabalho junto aos camponeses através das Ligas Camponesas. No entanto, foi através da participação no Movimento de Educação de Base (MEB) e na Superintendência para Reforma Agrária (SUPRA) que a AP conseguiu obter um contato maior com o mundo rural. (LIMA; ARANTES, 1984)

Durante os anos 60, os católicos e os organismos ligados a eles, como a Ação Popular, participaram e até mesmo criaram várias experiências de educação popular, dentre os mais significativos podemos citar o Movimento de Educação Popular baseado no método Paulo Freire, que foi desenvolvido em bairros populares em Salvador por militantes e simpatizantes da AP e o Movimento de Educação de Base (MEB), com o qual a AP realizou uma parceria promovendo um trabalho de alfabetização e conscientização política no interior da Bahia através de escolas radiofônicas.

Foi participando de atividades do MEB, da SUPRA através do sindicalismo rural e outras iniciativas independentes que a $\mathrm{AP}$ conseguiu criar vínculos com o movimento camponês. Chegando até mesmo a participar em 1963 da fundação da Confederação Nacional dos Trabalhadores Rurais, a CONTAG, e fazer parte da primeira diretoria deste órgão.

No que se refere à participação da AP no processo de fundação de sindicatos rurais antes do golpe, podemos destacar a experiência de Péricles de Souza que nos relatou que

No desdobramento dessa experiência de educação pelo rádio, de educação à distância pelo rádio e das aulas de educação de base veio a questão do sindicalismo rural, ou seja, no começo do governo João Goulart houve uma importante modificação no sentido progressista democrá- 
tico da legislação sindical rural [...] Com a mudança da legislação houve uma corrida ao campo de diversas forças políticas para criar sindicatos. Então os comunistas, o pessoal da AP, setores da Igreja até mais a direita, mais conservadores se puseram a criar sindicatos rurais pelo interior do país. Aqui na Bahia, o MEB daqui estadual constituiu uma chamada equipe de sindicalismo rural que eram pessoas voltadas para criação de sindicatos rurais no interior. Eu participei disso juntamente com outros companheiros como o Professor Elenaldo Teixeira, Vetúlia Carvalho Leite [...] era a organização de sindicatos de trabalhadores rurais, treinamento de suas diretorias do ponto de vista da AP, pretendíamos a elevação do nível da organização, de consciência política dos trabalhadores rurais. Nos fundamos uns 15 sindicatos rurais até o golpe. [...] Os primeiros sindicatos que nós organizamos, que eu me lembro, foram em Feira, em Cachoeira, em Cruz das Almas, em Santo Antonio de Jesus, São Miguel das Matas, Amargosa, Senhor do Bonfim, São Felipe. [...] Esses sindicatos não chegaram a consolidar eles tinham dois anos quando veio o golpe e fechou todos eles. ${ }^{2}$

A atuação da Ação Popular junto aos movimentos de sindicalização e educação camponesa concederia a AP certa experiência no trabalho de educação e organização das massas, o qual iria ser aprimorado com a experiência da "integração na produção"3 a partir de 1967.

Vale a pena ressaltar que a AP esforçou-se para criar vínculos no meio operário. No entanto, segundo Lima e Arantes (1984), a organização não encontrou no movimento operário a Juventude Estudantil Católica (JEC) ou a Juventude Universitária Católica que facilitaram sua inserção no movimento estudantil ou o MEB e a SUPRA que permitiram sua atuação no campo. A Juventude Operária Católica (JOC) e a Ação Católica Operária (ACO) foram entidades que em certos locais auxiliaram no crescimento da AP no meio operário, mas não na mesma intensidade que as entidades anteriormente citadas.

Além disso, não se pode esquecer que o Partido Comunista Brasileiro (PCB) possuía uma grande influência no meio operário. Mesmo diante de tais obstáculos a AP conseguiu estabelecer certos vínculos no movimento operário

\footnotetext{
${ }^{2}$ Entrevista com Péricles de Souza, 14 nov. 2004

${ }^{3}$ Usamos em todo o artigo a forma como a organização escreveu o termo "integração na produção" em seus documentos.
} 
e sindical urbano por meio de profissionais liberais, lideranças operárias, etc. $\mathrm{Na}$ Bahia, podemos citar o exemplo do Sindicato dos Trabalhadores na Extração do Petróleo presidido por um operário chamado Wilton Valença; o Sindicato dos Trabalhadores no Refino presidido por Mário Lima e a criação de uma base operária na Refinaria de Mataripe através de militantes que eram engenheiros e trabalhavam na empresa.

\section{O Golpe e a Ação Popular: a busca por novos horizontes teóricos}

A crescente radicalização política do movimento popular e dos trabalhadores que pressionavam o poder Executivo a romper com o pacto populista acabou levando as classes dominantes e setores das classes médias apoiados por agências governamentais norte-americanas e empresas multinacionais a condenarem o governo João Goulart. Desse modo, a derrubada de Jango contou com a participação das Forças Armadas, que a partir de abril de 1964 impuseram uma nova ordem política e social no país. (TOLEDO, 1997).

Com o golpe de 1964, todas essas atividades desenvolvidas pela Ação Popular foram interrompidas pela nova ordem que se estabeleceria, desde os trabalhos de educação e conscientização de camponeses através do MEB, a fundação de sindicatos e o trabalho de educação em bairros populares, já que incentivavam o senso crítico das massas, assim como a organização e mobilização dos operários.

$\mathrm{Na}$ Bahia, os militares se apressaram em neutralizar as cidades de Vitória da Conquista, Ipiaú e Feira de Santana, que eram chefiadas por partidários de João Goulart e poderiam se tornar possíveis focos de resistência.

Vale a pena ressaltar que em Feira de Santana, um grupo de estudantes formado por Péricles de Souza, Sérgio Gaudenzi e Raimundo Mendes, pertencentes à Ação Popular, tentou articular juntamente com o Prefeito Francisco Pinto uma forma de resistência ao golpe. Em depoimento, o ex-prefeito da cidade afirmou que:

A cidade de Salvador encontrava-se cercada pelas tropas e centenas de prisóes foram efetuadas. Vários líderes operários e estudantis que escapavam se deslocavam para o nosso município. Discutimos o que fazer e resolvemos resistir. Uma série de providencias foram adotadas para enfrentar os golpistas. Não cabe aqui enumerá-las. A ausência de reação no resto do país nos levou desmobilização. Provi- 
denciamos a fuga para a maioria dessas lideranças. (SANTOS, F., 1998, p. 28)

No depoimento, Francisco Pinto não revelou que providências seriam tomadas. Porém, Péricles de Souza, que fazia parte do grupo de estudantes da $\mathrm{AP}$, apontou que a cidade seria transformada em centro de resistência. Em relação a esse episódio, Péricles afirmou que:

Aqui na Bahia nós tomamos a iniciativa de resistir ao golpe, resistir no caso é aí a resistência armada ao golpe, e achávamos que deveríamos fazer a nossa parte já que Pernambuco resistiria, Rio Grande do Sul resistiria e nos tínhamos que fazer a nossa parte. Tomamos iniciativas, preparamos algumas ações até militares, foi feito até um plano de tomada do quartel da policia militar em Feira de Santana para a conquista de armamentos e pra resistência. Feira de Santana por que era uma cidade governada por Francisco Pinto, uma pessoa também ligada ao movimento de esquerda da base de apoio de Goulart e o movimento que nos tínhamos mais acesso que era esse movimento de trabalhadores rurais também nos tentamos mobilizar e reorganizar esses trabalhadores rurais para resistência. [...] Justamente na noite do golpe, mobilizamos vários grupos, companheiros da $\mathrm{AP}$, outros companheiros que não eram da $\mathrm{AP}$ participaram também disso [...] mandamos pra o interior esses grupos, mas o golpe acabou prevalecendo. ${ }^{4}$

Tentativas dessa natureza não foram realizadas somente na Bahia, porém ações sem planejamento e desarticuladas idênticas a esta não impediriam que os golpistas fossem vitoriosos. Segundo Toledo (1997, p. 42),

O golpe encontrou as esquerdas fragmentadas em diferentes correntes ideológicas, isoladas das grandes massas populares e sem nenhuma estratégia política para resistir a ação deflagrada. Subordinadas e vinculadas ao populismo janguista, não conseguiram as organizações populares e sindicais vislumbrar e implementar uma ação indepen-

${ }^{4}$ Entrevista com Péricles de Souza, 14 nov. 2004 
dente face ao capitulacionismo do governo Goulart. Com uma crescente retórica radical e pseudamente revolucionária, no pré-64, as esquerdas mostraram-se inteiramente inertes e desorientadas frente a ação militar [...] As massas populares e trabalhadoras não deram um passo - a não ser em casos muito isolados - em defesa do governo populista, assistindo passivamente ao desmantelamento de suas organizaçôes políticas e sindicais bem como a prisão de suas lideranças mais expressivas. Como um "castelo de cartas" desabou a chamada "frente democrática" que reuniria operários, camponeses, militares nacionalistas e estudantes.

Consumado o golpe, as perseguições políticas se iniciaram, sob a proteção do primeiro dos Atos Institucionais que seriam outorgados pelo governo, se abatendo sobre os mais ligados a movimentações políticas do período do governo Goulart, tais como sindicalistas, estudantes ligados a organizaçôes de esquerda etc.

Diante dessa nova realidade, muitos militantes deixaram a organização, outros passaram à condição de clandestinos e alguns saíram do país como José Serra, Herbert José de Souza, Aldo Arantes, Alípio Freitas, Paulo Wright, dentre outros.

Foi a partir do movimento estudantil que a Ação Popular começou a reorganizar suas atividades após o golpe, pois era na base estudantil que estava assentada grande parte da organização.

O movimento estudantil, embora desarticulado, começava a conviver com uma retomada gradual. Depois de 1964, os estudantes mobilizaram-se intensamente na luta contra a ditadura protestando pelo aumento das vagas nas universidades, contra a repressão, na luta contra a Lei Suplicy que extinguia a UNE e as Uniões Estaduais de Estudantes (UEEs) e, em seu lugar, criava o Diretório Nacional dos Estudantes (DNE) e Diretório Estadual dos Estudantes (DEE). A Lei impunha o voto obrigatório dos estudantes nas eleições das entidades - além do DNE e DEE, os Diretórios Acadêmicos (DAs) e Diretório Central dos Estudantes (DCEs) - dava poderes ao Ministério da Educação ou Conselho Federal de Educação para convocar suas reuniōes e proibia manifestaçôes de greve ou propaganda político-partidária. Além disso, os estudantes ainda se manifestavam contra os Acordos Ministério da Educação e Cultura e a United States Agency for Internacional Development (MECUSAID), organismo diretamente vinculado ao Departamento de Estado Ame- 
ricano. Esses acordos previam a assessoria de técnicos estrangeiros para auxiliar o governo militar na formação de uma nova política educacional. De acordo com João Roberto Martins Filho (1987, p. 130),

Os acordos MEC-USAID inseriam-se numa longa tradição de "colaboração técnica" entre o Brasil e os Estados Unidos da América, que remonta ao pós-45. Até 1956, no entanto, os convênios assinados se restringiram ao fornecimento de assessoria e equipamentos no setor do ensino técnico. No Governo Kubitschek, a influência americana ampliou-se a projetos no ensino elementar. $\mathrm{Na}$ década de sessenta, após a vitória da Revolução Cubana, o Departamento de Estado dos EUA mostrou renovado interesse em implementar acordos mais abrangentes. Entretanto, a crise do Governo Goulart fez com que, mesmo assinados, esses convênios permanecessem letra morta. Com o golpe de 64, a situação alterou-se significativamente e logo se retomaram os entendimentos com a USAID. A série de acordos assinados entre 1964 e 1966 é que passou a ser conhecida como os Acordos MEC USAID.

É importante lembrar que entre 1966 e 1969, a AP teve uma inserção bastante expressiva no movimento estudantil. Afinal, a organização conseguiu eleger sucessivos presidentes da União Nacional dos Estudantes (UNE) em congressos ocorridos na clandestinidade. Em 1966, José Moreira Guedes foi escolhido presidente da UNE; em 1967, Luiz Travassos; em 1969, Jean Marc Van Der Weid que acabou sendo preso e substituído por Hornestino Guimarães, assassinado pela polícia em 1973. (RIDENTI, 2002)

Porém, a AP encontrou dificuldades de retomar seus trabalhos nas frentes operárias e camponesas devido à intensidade da repressão que se abateu sobre as fábricas através da demissão e prisão de lideranças, e no campo sobre os trabalhadores que acabaram fugindo da repressão buscando serviço em outras regiōes. (LIMA; ARANTES, 1984)

Para as esquerdas, além da perseguição política, se iniciava a avaliação dos "erros" cometidos. De maneira que, esse novo contexto impunha as organizações de esquerda uma análise das formulações teóricas e estratégicas. Com o impacto do golpe civil-militar, a AP procurou redefinir suas influências teóricas e suas ações práticas, dando início ao processo de adesão ao marxismo. 
Imediatamente após o golpe, as mudanças ocorridas na Ação Popular começariam a ser anunciadas com a participação da organização na frustrada resistência armada comandada a partir do exílio uruguaio pelo ex-governador gaúcho Leonel Brizola e com as transformações ideológicas propostas através da aprovação da Resolução Politica (1965).

No documento Resolução Política, a organização apontou para a necessidade da luta armada revolucionária com nítida influência foquista. Segundo Sales (2005), as características do foquismo que aparecem neste documento são inúmeras. A AP colocava que o caminho para se chegar à Revolução Socialista de Libertação Nacional, conceito eclético que revelava uma mescla de influências, seria a luta armada. Apontando como caminho para a revolução socialista a luta insurrecional e como estratégia adotada a guerra de guerrilhas.

O foquismo passaria a fazer parte dos assuntos debatidos no seio da organização a partir de 1965 através dos Textos para debate, organizados pelo Comando Nacional, na tentativa de promover a definição ideológica da AP através da discussão desses textos. Entre alguns textos que foram publicados, estavam Guerra de guerrilhas: um método, de Ernesto Che Guevara; Castrismo: a longa marcha da América Latina e América Latina: alguns problemas da estratégia revolucionária, de Regis Debray (SALES, 2005).

Após o preparo teórico, a AP deu início a uma série de açóes militares. Tais como o atentado ao Aeroporto dos Guararapes em Recife, a expropriação de um banco no interior de Alagoas e a tentativa de sabotagem do processo eleitoral na Bahia, com a explosão de uma bomba no Fórum Ruy Barbosa. (OLIVEIRA JÚNIOR, 2000). Além disso, Jean Marc Van Der Weid, em depoimento a Marcelo Ridenti (2002, p. 227), afirmou que em 1967 setores castristas da AP prepararam um plano que não se concretizou para a tomada de cidades do Maranhão a partir da organização de camponeses liderados por Manoel da Conceição.

O atentado no Aeroporto de Recife é apontado por muitos autores como a maior expressão da influência foquista na Ação Popular. Militantes da AP prepararam, em 25 de julho de 1966, um atentado à bomba contra o General Costa e Silva. A bomba explodiria às 08: $45 \mathrm{~min}$, horário marcado para a chegada do presidente ao aeroporto. Mas, por problemas técnicos no avião, o presidente não chegou a decolar de João Pessoa para Recife. A bomba explodiu, matou duas pessoas e deixou catorze feridas, não atingindo seu alvo principal. Após essa ação militar com saldo negativo, a AP iniciou uma reavaliação 
da sua relação com Cuba, o que abriu espaço para um processo de aproximação com o maoísmo. ${ }^{5}$

Esse episódio afastou a AP do caminho das açôes armadas que foi seguido por grande parte da esquerda brasileira como a Ação Libertadora Nacional (ALN), a Vanguarda Popular Revolucionária (VPR), o Movimento Revolucionário 8 de outubro (MR-8), dentre outros. Tanto que, a AP participou ativamente da I Conferência da Organização Latino-Americana de Solidariedade (OLAS) que tinha como objetivo articular as forças revolucionárias de toda a América Latina. (GORENDER, 2003)

Ao mesmo tempo, militantes que se encontravam em Cuba e na China retornaram ao Brasil. A partir desse momento teve início no seio da organização uma luta interna que deu origem a duas linhas de pensamento na AP que ficaram conhecidas como: “Corrente 1" e "Corrente 2", a primeira defendendo as ideias chinesas e a segunda partidária das ideias cubanas.

A disputa entre essas duas correntes pode ser acompanhada através da leitura do documento Esboço Histórico da Corrente 01, no qual percebemos o embate entre as ideias de Mao Tsé Tung e a persistência das ideias cubanas na AP.

Através deste documento, podem-se acompanhar as reuniōes e debates em torno dessas duas correntes e até mesmo o posicionamento do Comando Regional 6, do qual a Bahia fazia parte, em relação a esse processo de luta interna. O documento nos fornece indícios de que, na região 06, possuía militantes influenciados pelo foquismo e por esse motivo havia a necessidade de se realizar um trabalho mais efetivo na região para que ela aderisse às propostas revolucionárias da "Corrente 01 ".

Em novembro de 1967, tinha estado na região o companheiro Do Comando Nacional, que já com as novas posições de Guerra Popular e pensamento de Mao Tse Tung fez um seminário de estudos que ajudou muito no avanço da visão política da região. (AÇÃO POPULAR, 1969b, p. 9)

A finalização dessa disputa entre as correntes internas se deu na I Reunião Ampliada da Direção Nacional, em julho de 1968, onde foi aprovado o documento Os seis pontos, que colocou o maoísmo como estratégia revolucionária a ser seguida.

\footnotetext{
${ }^{5}$ Concordamos com Sales (2005), quando ele afirma que não devemos facilitar a compreensão do processo complexo de transição do foquismo para o maoísmo, pois este ocorreu após longos debates internos entre 1966 e 1968, que discutiram questões como as características da sociedade brasileira, as diferenças entre o foquismo e a guerra popular etc.
} 
Após tantos debates e rachas internos, a Ação Popular escolheu o maoísmo e os defensores do foquismo acabaram sendo expulsos da organização. Tal grupo era composto por Vinícius Caldeira Brant, Altino Dantas e o padre Alípio Freire, que juntamente com outros formariam o Partido Revolucionário Tiradentes (PRT) o qual aderiu à guerrilha urbana chegando ao fim entre 1971 - 1972 após uma série de prisões e assassinatos dos seus militantes.

\section{O processo de "integração na produção": uma experiência maoísta na Bahia $^{6}$}

O primeiro contato da Ação Popular com os chineses ocorreu no Seminário do Estudante do Mundo Subdesenvolvido, realizado em Salvador em 1963, onde os militantes da AP foram convidados para irem a China. Este convite se concretizou oficialmente em 1966 com a ida de Aldo Arantes ao país em plena "Revolução Cultural Proletária". O impacto dessa viagem pode ser percebido através documento escrito pelo próprio Aldo, chamado Texto Amarelo, no qual ele abordou questôes como guerra popular, movimento camponês etc.

A adesão ao maoísmo se tornou oficial somente após uma segunda visita de um grupo da organização chefiado por Jair Ferreira de Sá no segundo semestre de 1967. Retornando da China, ele mesmo redigiu o documento Os seis pontos (1968), que ratificou o maoísmo como opção teórica a ser seguida e tornou a integração oficial na Ação Popular, a qual passou a ser definida como uma forma superior de integração na vida das massas.

Com a escolha do maoísmo como estratégia revolucionária, os militantes da AP começaram a preparação da guerra popular no Brasil através da integração dos seus quadros à produção. A influência maoísta pode ser observada através da semelhança entre o processo de integração e o processo de "reeducação ideológica" que era colocado em prática naquele período na China, durante o auge da Revolução Cultural. O ideal de reeducação baseava-se no envio dos quadros do Partido Comunista Chinês periodicamente ao campo ou as fábricas para que estes não perdessem o contato com as massas e o trabalho produtivo. Inspirada nessa experiência, a AP colocou em prática a integração que inicialmente tinha como objetivo único a transformação ideológica dos seus quadros oriundos da pequena burguesia, os quais deveriam superar os seus limites de classe através do trabalho produtivo no campo e nas fábricas e por meio do contato com as massas

${ }^{6}$ Para maiores informaçôes sobre o processo de integração desenvolvido pela Ação Popular e a influência do maoísmo sobre este. Ver: Santana (2008). 
No documento Profissionalização dos quadros: uma necessidade urgente (1966) aparece pela primeira vez a concepção da integração, demonstrando uma preocupação com a formação teórica e prática da militância, a qual necessitava se preparar tecnicamente e teoricamente para a realização de um trabalho revolucionário, ou seja, integrarem-se às massas operárias e camponesas para a realização de um trabalho político.

Este documento demonstra a conotação política da "integração na produção", o que aponta uma mudança no sentido dessa proposta que até então era colocada somente como uma forma de seus militantes pertencentes à pequena burguesia se livrarem dos seus limites de classe.

Estudantes e intelectuais são deslocados de suas áreas habituais de atividade para áreas operárias e camponesas. Neste caso, os quadros estudantes e intelectuais não tem conhecimento suficiente do meio, contatos, a ambientação necessária. Por isso defendemos como primeiro passo do trabalho, a sua integração, pelo menos num período inicial, no trabalho produtivo na fábrica ou no campo. Isto é também muito proveitoso e importante também do ponto de vista da formação pessoal dos militantes. Mas o objetivo principal da profissionalização e da integração na produção é a criação de condições para o desenvolvimento de um trabalho revolucionário, deve-se tomar cuidado para que a integração na produção não impeça o trabalho político do militante, trabalho que exige disponibilidade de tempo e mobilidade. Deve-se encontrar, em cada caso concreto, um equilíbrio entre as necessidades da integração na produção e as exigências do trabalho político. Todos esses princípios se aplicam também ao caso de operários e camponeses que sejam transferidos de sua região para outra e tenham, por isso, necessidade de integração inicial no trabalho produtivo para o estabelecimento de contatos e identificação com as massas. (AÇÃO POPULAR, 1966, p. 10)

A preocupação com a formação do partido de vanguarda por parte da Ação Popular aparecia também nesse documento, no qual foram apontadas as condições que uma organização revolucionária deveria possuir para se tornar a vanguarda. Dentre estas, alterações na composição da organização, a qual deveria possuir em suas fileiras militantes da classe operária e camponesa e a 
estrita ligação do partido com os operários e camponeses para a condução efetiva da luta de massas dentro de uma visão política e estratégica. Assim, a falta desses requisitos para que a organização se tornasse o partido de vanguarda do proletariado fez com que surgisse a necessidade da ampliação das suas bases, que seria feita através da integração dos seus quadros ao trabalho produtivo no campo e nas fábricas.

Acreditamos que o contato cada vez maior com a teoria maoísta fez com que os objetivos do processo da "integração na produção" se transformassem. A partir de 1966, notam-se na documentação da AP as mudanças nos objetivos da integração, a qual passaria a ser designada também como uma forma dos militantes da AP se inserirem junto aos operários e camponeses visando sua educação, organização e mobilização em prol da ampliação das bases do partido no campo e na fábrica e da articulação da guerra popular prolongada no Brasil. Desse modo, podemos afirmar que a Ação Popular inspirou-se na estratégia dos chineses em outro período da história recente da China, que foi a Revolução Chinesa. Nesse contexto, os militantes do Partido Comunista Chinês se inseriam na vida e no trabalho nas massas para tentar educá-los e mobilizá-los para a luta de libertação nacional do país.

Percebemos que o objetivo de superação dos limites de classe passaria a aparecer nos documentos como algo secundário no desencadeamento da integração sendo ressaltado como elemento facilitador da integração e não seu fator principal. De modo que, no documento Integração com as massas: roteiro para uma discussão foram colocados como aspectos fundamentais da prática o ideal de servir ao povo e se integrar na vida das massas como base objetiva para a direção da luta de classes.

A "integração na produção" foi frequentemente associada por alguns autores com as origens cristãs da Ação Popular, tendo como referência para esse processo a experiência dos padres operários. Sabe-se que a experiência dos padres operários franceses surgiu no final da década de 40, quando o Episcopado Francês encarregou alguns padres de passarem a viver como trabalhadores comuns e descobrirem os motivos que levavam a classe operária francesa a possuírem certa descrença em relação à religião. Porém, o objetivo principal dessa iniciativa era fornecer dados para que a Igreja pudesse combater as ideias materialistas e, obviamente, a influência, então, bastante expressiva do Partido Comunista Francês (FERREIRA; ALMEIDA, 1993).

Com base na análise feita por Moraes (2003) em sua dissertação sobre a experiência dos padres operários no ABC Paulista, foi possível perceber que a forma de ligação com as massas realizada pela Ação Popular tinha objetivos 
completamente diferentes do trabalho realizado pelos padres operários. A Ação Popular enviava seus militantes para integrarem à produção visando o desencadeamento de um trabalho político para transformar a sua condição socioeconômica, enquanto os padres operários se inseriam no mundo dos trabalhadores visando a sua evangelização para afastá-los do comunismo.

As primeiras experiências da integração partiram de São Paulo e da Bahia no segundo semestre de 1967. Sua prática continuou sendo aplicada com intensidade em 1968 e 1969, começando a ser desarticulada em meados de 1970 no estado da Bahia, de acordo com os depoimentos concedidos à autora.

Arrolamos 23 frentes de trabalho entre pequenas e grandes, importantes e secundárias, distribuídas por oito áreas geográficas que a AP definia como "regiōes": Pará, Maranhão, Nordeste, Bahia e Sergipe, Minas Gerais, São Paulo, Paraná e Goiás. Dentre o pessoal que se "integrou" nessas frentes identificamos um grupo de 120 companheiros [...] das 120 pessoas referidas, 90 se dirigiram ao campo, "integrando-se" na produção agrícola como assalariados rurais ou camponeses, 30 dirigiram-se à produção fabril'. (LIMA; ARANTES, 1984, p. 116)

Os militantes da AP que participaram do processo de "integração na produção" em seus princípios integravam no mesmo estado em que viviam. Porém, com o recrudescimento da Ditadura Militar após o decreto do Ato Institucional no 5, a Ação Popular passou a enxergar na integração uma forma de segurança da militância da organização, o que deu margem à necessidade de deslocamentos dos militantes para o trabalho nas áreas prioritárias de outros Estados.

A Ação Popular promoveu uma verdadeira empreitada de pesquisa e preparação dos militantes para colocar em prática a "integração na produção" junto aos camponeses e operários. Foi montado um grupo formado por militantes da AP que desenvolveram uma pesquisa que recebeu o nome de Pesquisa de Áreas Estratégicas (PAE) para a escolha das chamadas bases de apoio, também chamadas de áreas prioritárias ou bases estratégicas, para que os militantes colocassem em prática a integração junto às massas. A pesquisa realizada pela organização levava em conta aspectos econômicos, sociais, políticos e geográficos.

\footnotetext{
${ }^{7}$ Existem controvérsias a respeito da quantidade de militantes integrados à produção, na medida em que Jair Ferreira
} de Sá afirmou que o número de militantes integrados variava em torno de 1.000 (Cf. GUSMÃO, 1979). 
01-Condição de massa (peso total 9)- a) aspecto de quantidade $=4 /$ numero de camponeses $=3 /$ grau de concentração $=1 \mathrm{~b}$ ) aspecto de qualidade $=5 /$ composição de classe $=2 /$ nivel de luta $=1 /$ tradição de luta $=0,5 /$ organização de massa $=0,5$ /organização de Partido=0,5. 02- Condições físicas (peso total 5) - altitude - relevo=3/rios e alagadiços= $1 /$ vegetação e clima $=1$. 03- Condições do inimigo: presença do inimigo $=3 /$ condições para expansão $=2 /$ condiçóes econômicas=2/ importância econômica=1. (AÇÃO POPULAR, 1969a, p. 131)

As bases de apoio no campo escolhidas no estado da Bahia para o envio dos militantes foram Panelinha, Camacã, Eunápolis, Itabuna, Ilhéus e algumas cidades da região da Chapada Diamantina.

Inseridos no trabalho, os militantes começavam a participar da vida e dos problemas sociais e econômicos das massas. Partindo dessas questóes concretas, iniciaram um trabalho de conscientização política das massas, visando mostrar aos camponeses a dominação ideológica e a exploração econômica às quais estavam submetidos e as formas como eles poderiam lutar contra os opressores.

A educação e a propaganda das massas deve se fazer em torno dos problemas concretos e mais diretamente ligados à vida do camponês: situação de miséria dos camponeses, morte do filho, gado do latifúndio que comeu a roça do camponês, latifundiário que bateu no camponês etc. Partir sempre dos problemas concretos através de imagens que facilitem a compreensão do camponês para chegar até os problemas mais gerais. (AÇÃO POPULAR, 1968, p. 13)

Para a realização desse papel de educador político, a AP preparava sua militância através de um programa de estudos permanente e bem estruturado, no qual se incluíam textos de Marx, Lênin, Mao Tsé Tung, textos que narrassem à experiência dos militantes, documentos gerais da Ação Popular e de outras organizações etc. Além dessa preparação teórica para a integração, militantes da AP, como Jair Ferreira e Manuel da Conceição, chegaram a realizar um curso de capacitação política e militar na Academia Militar de Nanquim, na China.

A militância utilizava-se dos mais variados instrumentos para educar as massas. No que se refere à Bahia, encontramos os seguintes artifícios usados 
com esse objetivo: o script de uma peça de teatro ${ }^{8}$, que tratava da realidade dos trabalhadores do cacau, tais como a falta de assistência médica, educação, eleição, exploração do trabalhador, prostituição e assassinatos de trabalhadores rurais; músicas (violeiros); a circulação de um jornal chamado Boletim do Trabalhador Rural ${ }^{9}$, onde eram narrados acontecimentos que demonstram a exploração sofrida por trabalhadores nas cidades de Camacã e Eunápolis e um plano de um curso de alfabetização de adultos ${ }^{10}$ oferecido na Região Cacaueira.

Durante a realização deste trabalho político, o militante deveria tentar identificar lideranças no campo, visando ampliar as fileiras do partido com a entrada de militantes de origem camponesa. $\mathrm{O}$ recrutamento de militantes de origem camponesa não foi atingido pelos integrados à produção nas áreas rurais na Bahia, na medida em que eles não passaram mais que 3 meses realizando o trabalho político na região em que se inseriram devido à falta de adaptação ao trabalho na roça; às perseguições da repressão; etc. Como um exemplo das dificuldades encontradas pelos militantes integrados tem-se o depoimento de Arruti, o qual relatou que:

Nem conhecia o processo produtivo do cacau, eu passei ali quase vinte dias aprendendo o que é que era o cacau, o que não era, como é que se fazia, quantas safras era, quantas não era. Então, era um processo grande, eu não era de uma região, não vinha de uma região agrícola com essas características, vinha da região de Goiás aonde era um desmate de plantação de arroz, desmate de estoque. Então pra você chegar numa área de assalariado no cacau que eu nunca tinha visto, então tinha a limpa, a poda, etc, colher cacau, tinha várias coisas, várias etapas do processo, então primeiro até a linguagem, o linguajar, os termos eram complicados, quer dizer, pra mim. ${ }^{11}$

A integração da militância da AP não se restringiu ao campo, pois foi possível registrar a prática dessa mesma linha de trabalho político nas áreas urbanas por meio da ida dos seus militantes às fábricas vistas como prioritárias nas cidades de Salvador e Candeias.

\footnotetext{
${ }^{8}$ AÇÃO POPULAR: Sem título, s/d.

${ }^{9}$ AÇÃO POPULAR: Boletim do Trabalhador Rural, n. 6.

${ }^{10}$ AÇÃO POPULAR: Curso (alfabetização de adultos), 1968.

${ }^{11}$ Entrevista com José Carlos Arruti, 21 set. 2004
} 
Dentro do cenário fabril, existiam também as categorias tidas como prioritárias, nas quais a militância deveria buscar emprego para iniciar um trabalho político. Essas categorias eram a metalúrgica, a têxtil, os trabalhadores da indústria de alimentação, portuários e químicos (AÇÃO POPULAR, 1969a).

Maria Lúcia de Souza atuou na área têxtil. Segundo ela, "o tempo de integração na produção, em Salvador, eu entrei na Nordisa, era uma empresa do pólo, da CIA é do Centro Industrial de Aratu, também uma empresa que tinha também certa automação" ${ }^{12}$. Já Eliana Rollemberg tentou se inserir no ramo da indústria química:

[...] eu fui trabalhar numa região mais ligada ao petróleo, Candeias, aqui na Bahia. Era uma cidade dormitório dos trabalhadores da Petrobrás, do petróleo. Então se discutia muito com os sindicatos todo um engajamento nessa parte mais de sindicalismo urbano. ${ }^{13}$

O ex-militante Benjamim Ferreira, que atuou nas indústrias de óleos vegetais e metalúrgicas, relembra o seguinte:

Integrei naquela fábrica de óleo vegetais de nome Reseguer ali em Paripe, não sei se ainda existe. Eu comecei a trabalhar ali e, fui manuseando as máquinas. Eu trabalhava com mamona né? Eu municiava aquela máquina a noite inteira, e um cara passou, um chefe que era ali um chinês e viu eu trabalhando ali e disse, onde você gostaria de trabalhar? Eu disse, na área de manutenção que é onde eu tenho certa experiência. Aí ele me botou lá e de lá eu fui pra Cesmel que fechou, funcionava ali na Brasil Gás onde funciona parece que hoje é a Coelba [...] de lá pra Bosch, aí foi na Bosch que eu fui preso. ${ }^{14}$

Os ex-militantes da Ação Popular que foram entrevistados e participaram da "integração na produção" fabril na Bahia atuaram ou pelo menos tentaram atuar nessas categorias vistas como prioritárias.

\footnotetext{
${ }^{12}$ Entrevista com Maria Lúcia de Souza, 7 abr. 2006

${ }^{13}$ Entrevista com Eliana Rollemberg, 21 set. 2004

${ }^{14}$ Entrevista com Benjamim Ferreira, 7 out. 2004
} 
Seguindo a mesma linha de trabalho realizada no campo, os militantes integrados à fábrica começariam a analisar questôes como o agravamento das condiçōes de vida e de trabalho; o crescente desemprego; a repressão da ditadura contra os operários; etc. Juntamente com essas questões, o nível de consciência dos operários perante esses problemas vinculados à sua realidade social, econômica e política deveria ser observado. Com essa análise feita, o militante poderia começar a traçar sua estratégia de atuação dentro da fábrica onde estivesse integrado.

As conversas eram utilizadas pelos militantes para que eles tomassem conhecimento dos problemas sofridos pelos trabalhadores das fábricas, assim como para descobrirem novos companheiros, os quais pudessem ingressar no partido. Afinal, um dos principais objetivos da "integração na produção" era ampliar as bases da AP nos meios operários e camponeses através do recrutamento de militantes.

Os três entrevistados nos forneceram pistas importantes a respeito das fábricas prioritárias em Salvador. Isso nos permitiu mapear as áreas onde os integrados atuaram tais como os bairros ou até regiōes de concentração operária como Paripe; o Centro Industrial de Aratu, em Simões Filho e a Refinaria Landulpho Alves, em São Francisco do Conde, nos quais os militantes se fixaram visando realizar um trabalho de educação política.

Os militantes da AP também se inseriram nos bairros populares de Salvador para a realização desse mesmo estilo de trabalho de educação política.

Aqui em Salvador tinha integração. Na periferia, no bairro do Uruguai morava muita gente [...] em Paripe por ali trabalhavam naquelas fábricas [...] Tinha uma fábrica de tecidos, mas agora me foge o nome da fábrica, eu sei que era uma fábrica de tecidos [...] Aquele bairro ali de Brotas. Como é mesmo o nome dele? Cosme de Farias! Tinha gente que morava ali, tinha uma delas que eu dava dinheiro. $^{15}$

A atuação da organização no bairro também tinha como intenção fortalecer o trabalho na fábrica, na luta contra a repressão e a pelas reivindicações econômicas. $\mathrm{O}$ ex-militante integrado à produção, Benjamim, aponta que:

Lá no bairro sempre senti uma facilidade assim de me relacionar com as pessoas assim perto, então nós começa-

\footnotetext{
${ }^{15}$ Entrevista com Iranildes Vianna, 14 set. 2004
} 
mos ali um processo de ajuda a construção da Igreja, de lá da capelinha de São Caetano [...]. Dentro disso aí fomos puxando a formação do grupo de jovens só que o grupo de jovens tinha alguns companheiros que não eram da AP, passaram a ser militantes, por que a gente começou a puxar para participar da militância. ${ }^{16}$

A partir do seu depoimento, vemos que esses trabalhos de extensão realizados nos bairros proletários, como por exemplo, em São Caetano, tiveram como saldo importante o recrutamento de novos militantes para a organização.

Vivendo, comendo e trabalhando como as massas operárias e camponesas, os integrados à produção acreditavam que dessa forma conseguiriam se inserir na luta das massas para que fossem criadas raízes sólidas do partido através do recrutamento dos militantes de origem camponesa e operária para a Ação Popular visando a organização da guerra popular prolongada no Brasil.

Com base nas memórias destes ex-integrados à produção pudemos conhecer um pouco sobre essa proposta tão distinta de luta contra a ditadura e fornecer uma contribuição importante na tentativa de reconstrução dessa experiência colocada em prática pelos militantes da Ação Popular que integraram à produção no campo ou na fábrica no Estado da Bahia.

\section{Incorporação da Ação Popular ao Partido Comunista do Brasil}

Com a adesão da AP ao maoísmo, a organização aproximou-se do PC do $\mathrm{B}$, pois este era o correspondente oficial do Partido Comunista Chinês no Brasil. De acordo com Duarte Pereira em depoimento ao historiador Marcelo Ridenti (2002, p. 273): "Foi a direção da AP que buscou, insistentemente, estimulada pelo PC da China, a ação comum com o PC do B, os contatos entre as duas direçóes e as trocas de informaçóes e opinióes". De forma que, a partir de 1969, a AP e o PC do B iniciaram contatos oficiais ao nível de direção nacional e deram início a um trabalho de colaboração entre os partidos.

$\mathrm{Na}$ II Reuniāo Ampliada da Direção Nacional (RADN) realizada em julho de 1969 orientou-se a militância para a preparação da guerra popular e se discutiu a reconstrução do partido unificado do proletariado brasileiro. Nesta reunião limitou-se a aproximação com o PC do B, pois apesar desta já se achar em andamento, ainda encontrava oposição por parte da organização.

${ }^{16}$ Entrevista com Benjamim Ferreira 7 out. 2004 
Após a II RADN uma nova delegação foi enviada para China. Uma dos enviados foi Paulo Wright o qual encontrou uma China completamente distinta daquela que havia surpreendido tanto a Ação Popular. As percepções da viagem associaram-se aos questionamentos que ele já tinha em relação à análise que a AP fazia da formação social brasileira. Após seu retorno ao Brasil, Paulo Wright redigiu o documento Cinco pontos da luta interna fazendo uma análise crítica da interpretação feita pela AP sobre o caráter da sociedade e da revolução, sobre a questão do partido etc. Neste documento, o autor explicitava suas posições dando início a uma nova e decisiva luta interna.

Nesse contexto de luta interna e reinterpretação das posturas teóricas e práticas, durante a realização da IV Comissão Executiva Provisória em outubro de 1969 teve início o processo de autocrítica da organização em relação às atividades desenvolvidas até então. Nesse momento, a AP iniciaria uma análise crítica do seu movimento de integração, pois as sucessivas prisões dos militantes integrados à produção também forneceriam subsídios para reavaliação das concepções táticas da organização.

O processo de luta interna na AP aumentou durante a preparação para III RADN, realizada em março de 1971, onde maioria da organização demonstrou-se identificada em termos ideológicos e de programa com o Partido Comunista do Brasil e uma minoria permanecia contrária a fusão. Após a reunião, a AP passou a se chamar Ação Popular Marxista Leninista do Brasil (APML) e aprovou um programa básico que manteve precariamente a unidade da AP.

A luta entre a minoria representada na direção nacional por Jair Ferreira de Sá e Paulo Wright e a maioria por Aldo Arantes, Haroldo Lima e Aldo Rabelo teve continuidade entre 1971 e 1972, até ocorrer à ruptura no ano de 73 , quando ambos os grupos passaram a reivindicar a sigla APML. A minoria acabou sendo destituída dos seus cargos e expulsa da organização, e tentaram continuar organizando-se em torno da sua APML (RIDENTI, 2002).

Com a expulsão da minoria, a maioria do Comitê Central da Ação Popular Marxista Leninista do Brasil, decidiu em janeiro de 1973 pela incorporação ao Partido Comunista do Brasil, reconhecendo neste o autêntico partido de vanguarda do proletariado. 


\section{REFERÊNCIAS}

AÇÃO POPULAR. Audácia nos objetivos e rigor nos métodos. Jun. 1969a.

. Esboço de um histórico da Corrente 1. $1969 \mathrm{~b}$.

1968. . Política de massas de caráter revolucionário para o movimento camponês. Jun.

. Profissionalização dos quadros: uma necessidade urgente. Texto para militantes n. 4, jun. 1966.

ARRUTI, J.C. Militância na Ação Popular: depoimento oral. Salvador: [s.n.], 20 set. 2004. 1 fitacassete (60 min), son., estéreo. Entrevistadora: Cristiane Soares de Santana. Entrevista concedida a aluna regular do Curso de Mestrado em História Social, Exmilitante Ação Popular).

DIAS, R. Sob o signo da revolução brasileira: a experiência da Ação Popular do Paraná. Maringá: Eduem, 2003.

FERREIRA, B. Militância na Ação Popular: depoimento oral. Salvador: [s.n.], 7 out. 2004. 1 fitacassete (60 min.), son., estéreo. Entrevistadora: Cristiane Soares de Santana. Entrevista concedida a aluna regular do Curso de Mestrado em História Social. (Exmilitante Ação Popular).

FERREIRA, M.; ALMEIDA, E. Marxistas e cristãos: ontem e hoje. Revista Princípios, São Paulo, v. 1, n. 29, p. 44-46, 1993.

FERREIRA, M. M.; AMADO, J. (Org.). Usos e abusos da história oral. Rio de Janeiro: Fundação Getúlio Vargas, 1996.

GORENDER, J. Combate nas trevas. São Paulo: Ática, 2003.

GUSMÃO, S. B. Jair, clandestino há 15 anos. Jornal da República, São Paulo, 8 set. 1979.

LIMA, H; ARANTES, A. História da ação popular: da JUC ao PC do B. São Paulo: AlfaÔmega, 1984.

MANFREDINI, L. As moças de Minas: uma história dos anos 60. São Paulo: AlfaÔmega, 1989.

MARTINS FILHO, J. R. Movimento estudantil e militarização do estado no Brasil (19641968). São Paulo: Papirus, 1987.

MORAES, M. B. A Ação social católica e a luta operária: a experiência dos jovens operários católicos em Santo André (1954-1964). 2003. 207f. Dissertação (Mestrado em História) - Instituto de Filosofia e Ciências Humanas, Universidade de São Paulo, 2003.

NADER, A.B. Os autênticos do MDB: semeadores da democracia. História Oral e vida política. São Paulo: Paz e Terra, 1998.

OLIVEIRA JÚNIOR, F. Paixão e revolução: capítulos sobre a história da AP. 2000. 550 f. Tese (Doutorado em História) - Instituto de Filosofia e Ciências Humanas, Universidade Federal Pernambuco. 
OLIVEIRA, M. Militantes operários e operários militantes: a experiência da "integração na produção" na história da Ação Popular (1965-1970). 2005. 213 f. Dissertação (Mestrado em História) - Instituto de Filosofia e Ciências Humanas, Universidade Estadual de Campinas.

RIDENTI, M. Ação Popular: marxismo e cristianismo. In: RIDENTI, M.; REIS, D.A. (Org.). História do marxismo no Brasil: partidos e organizaçóes dos anos 20 aos 60. Unicamp: São Paulo, 2002. v. 5, p.227.

ROLlEMBERG, E. Militância na Ação Popular: depoimento oral. Salvador: [s.n.], 21 set. 2004. 1 fitacassete (60 min), son., estéreo. Entrevistadora: Cristiane Soares de Santana. Entrevista concedida a aluna regular do Curso de Mestrado em História Social. (Ex-militante Ação Popular).

SALES, J.R. O impacto da revolução cubana sobre as organizaçôes comunistas brasileiras (1959-1974). 2005. Tese (Doutorado em História) - Instituto de Filosofia e Ciências Humanas, Universidade Estadual de Campinas.

SALES, J. R. Partido Comunista do Brasil - PC do B: propostas teóricas e prática política (1962-19676). 2000. Dissertação (Mestrado em História) - Instituto de Filosofia e Ciências Humanas, Universidade Estadual de Campinas.

SANTANA, C. S. Maoísmo na Bahia (1967-1970). 2008. Dissertação (Mestrado em História) - Faculdade de Filosofia e Ciências Humanas, Universidade Federal da Bahia.

SANTOS, F.P. dos. Depoimento. In: NADER, A.B. Os autênticos do MDB: semeadores da democracia: história oral e vida política. São Paulo: Paz e Terra, 1998.

SOUZA, L.A.G. de. A JUC: os estudantes católicos e a política. Petrópolis, RJ: Vozes, 1984.

SOUZA, M. L. de. Militância na Ação Popular: depoimento oral. Salvador: [s.n.], 8 abr. 2006. 1 fitacassete (60 min), son., estéreo. Entrevistadora: Cristiane Soares de Santana Entrevista concedida a aluna regular do Curso de Mestrado em História Social. (Exmilitante Ação Popular).

SOUZA, P. de. Militância na Ação Popular: depoimento oral. Salvador: [s.n.], 14 nov. 2004. 2 fitacassete (120 min), son., estéreo. Entrevistadora: Cristiane Soares de Santana. Entrevista concedida a aluna regular do Curso de Mestrado em História Social. (Exmilitante Ação Popular).

TOLEDO, C. N. de (Org.). 1964: visóes críticas do golpe: democracia e reformas no populismo. Campinas, SP: Editora da UNICAMP, 1997.

VIANNA, I. Militância na Ação Popular: depoimento oral. Salvador: [s.n.], 14 set. 2004, 1 fita cassete (60 min), son., estéreo. Entrevistadora: Cristiane Soares de Santana Entrevista concedida a aluna regular do Curso de Mestrado em História Social. 


\section{ENTREVISTADOS}

Benjamim Ferreira, em 07/10/2004.

Eliana Rollemberg, em 21/09/2004.

Iranildes Vianna, em 14/09/2004.

José Carlos Arruti, em 20/09/2004.

Maria Lúcia de Souza, em 07/04/2006.

Péricles de Souza, em 14/11/2004. 



\section{9 \\ Dom Avelar Brandão Vilela e a ditadura militar}

Grimaldo Carneiro Zachariadhes ${ }^{1}$

Este artigo pretende abordar a atuação do Cardeal Dom Avelar Brandão Vilela no período de seu arcebispado na arquidiocese de Salvador durante a ditadura militar. Utilizando, principalmente, a documentação do seu arquivo pessoal, ${ }^{2}$ procurarei demonstrar a atuação do prelado em um Regime de exceção que se pautou pela violação dos direitos humanos e a restrição às liberdades individuais. Demonstrarei, também, a tentativa do arcebispo de Salvador de procurar dialogar com os vários setores da sociedade, tentando ser um moderador dos conflitos sociais e políticos.

\section{O Bispo do Diálogo}

Em 30 de maio de 1971, D. Avelar Brandão Vilela tomava posse como arcebispo da Sé primacial do Brasil, substituindo D. Eugênio de Araújo Sales, que tinha assumido o arcebispado do Rio de Janeiro. Antes de assumir a

\footnotetext{
${ }^{1}$ Mestre em História Social pela Universidade Federal da Bahia (UFBA). Está atualmente realizando uma pesquisa sobre o arcebispado de D. Avelar Brandão Vilela na arquidiocese de Salvador (1971-1986).

${ }^{2} \mathrm{O}$ arquivo pessoal de D. Avelar Brandão Vilela está guardado no Laboratório Eugênio Veiga, na Universidade Católica do Salvador (LEV/UCSAL).
} 
arquidiocese de Salvador, ele já tinha sido bispo da diocese de Petrolina, em Pernambuco (1946-1955) e arcebispo da arquidiocese de Teresina, no Piauí (1955-1971). Projetou-se nacionalmente pelas funções que assumiu junto à Conferência Nacional dos Bispos do Brasil (CNBB), chegando a ser vice-presidente da CNBB, em 1964. D. Avelar se tornaria também presidente do Conselho Episcopal Latino Americano (CELAM), tendo por isso uma grande responsabilidade na coordenação da Conferência de Medellín, em 1968. Já comandando a arquidiocese de Salvador, seria nomeado Cardeal pelo Papa Paulo VI, em 1973 (ZACHARIADHES, 2008).

D. Avelar Brandão Vilela é tido como um bispo moderado em suas posições políticas e sociais. Ele mesmo se atribuiu esse adjetivo em várias ocasiões. O arcebispo de Salvador tentava dialogar com os vários setores da sociedade, evitando entrar em radicalismos, deixando sempre a porta aberta para todos. Para muitos leigos e religiosos, D. Avelar se comportava como um pai, aquele que procurava manter todos ao seu redor. ${ }^{3}$

O prelado procurava conversar com todos: com os políticos de esquerda, de direita, setores católicos ligados à Teologia da Libertação e com setores mais tradicionais da Igreja Católica. Nem quando ele discordava da orientação, ele se fechava ao diálogo, tendo procurado manter contatos com os marxistas e até com os maçons. Porém, esta busca pelo diálogo com os mais diferentes segmentos da sociedade não era feita de forma passiva, como ele mesmo avisou:

Sou um moderado, não sou água estagnada. Sou apenas de dizer basta quando se ultrapassam os limites. É um estilo de vida, um desejo de Pastor. Os radicalismos têm propostas, mas não posso aceita-las na íntegra. Tiro o que é bom de um lado e de outro. Minha capacidade de ser moderado, entretanto, não é passiva. ${ }^{4}$

D. Avelar assumiu a arquidiocese de Salvador em um momento extremamente delicado, em que o país vivia sob um regime de exceção, a Ditadura Militar (1964-1985). Mesmo em um momento de radicalização

\footnotetext{
${ }^{3}$ Vários entrevistados usaram a imagem de "pai”, "paizão", "grande pai” para definir o Cardeal de Salvador. Entrevistas com padre Francisco Xavier Barturen (09-10-06), Monsenhor Gaspar Sadock (10-06-08), Monsenhor Walter Magalhães (7-11-08), Monsenhor Ademar Dantas (13-10-08), Padre André Seutin (21-10-08) e os leigos Joviniano Carvalho Neto (07-02-07), Yvette Amaral (10-10-08) e Antônio Ferreira Guerreiro de Freitas (31-10-06)

4 “Não sou oposição, sou Pastor”. Istoé, p. 85, 23 jun. 1982.
} 
política como no Regime dos militares, D. Avelar procurava manter o diálogo com os vários setores da Igreja Católica e da sociedade, ${ }^{5}$ tentando administrar os conflitos, pois assim ele entendia ser a função do bispo, do Pastor:

Um grupo entende que a palavra do Pastor deve ser exclusivamente de cunho espiritual [...] outro grupo defende a tese de que a missão profética do Pastor deve necessariamente conter denúncias e fazer acusações abertas e até violentas.

Para uma corrente de sociólogos e de teólogos, o Pastor deve exatamente conduzir as idéias na esteira de suas convicções políticas e filosóficas.

Para outros, a palavra do Pastor deve ser revolucionária e dirigida para a ação concreta de transformação radical das estruturas.

Assim cada cabeça, cada sentença.

No meio de toda essa efervescência de sentimento encontra-se o Pastor. ${ }^{6}$

\section{Avelar e os militares}

O arcebispo de Salvador se manteve sempre disposto ao diálogo com os militares. Mesmo no momento de maior repressão da ditadura, ele evitava fazer críticas abertas ao Regime. Na documentação guardada no arquivo particular de D. Avelar Brandão Vilela, pode-se perceber como o Cardeal era próximo de setores do Governo e como, a todo o momento, tentou evitar um conflito que impedisse o diálogo com os militares, mesmo nos momentos de crise que o envolvia diretamente.

Atendendo ao convite do General Rodrigo Octávio, comandante da Escola Superior de Guerra (ESG), D. Avelar aceitou ministrar uma conferência nesta instituição em 23 de setembro de 1971. O título da Conferência de D. Avelar foi A Igreja e o Estado no Brasil. Nela, o arcebispo perguntava aos militares: "Por que temer o diálogo? Não seria esta a hora indicada para que se

\footnotetext{
${ }^{5}$ Foi por esse comportamento de querer dialogar com todo mundo que alguns setores chamavam, jocosamente, D. Avelar de "Cardeal-sabonete", pois ele "escorregava em todas as mãos".

${ }^{6}$ Páscoa: Presença, Luta e Esperança de Liberação. Mensagem do Pastor, 17 abr. 1973.
} 
abrisse amplo e criterioso diálogo de âmbito nacional”. D. Avelar tocou em pontos mais críticos ao Regime e afirmava que "a necessidade de Segurança Nacional pode [...] criar um clima de medo perigoso". Avisava que com a censura, a Imprensa poderia perder o seu direito de criticar "honestamente" e que a juventude poderia "explodir em acesso de violência ou então, acomodarse excessivamente". E colocava: "Deve-se registrar que, tanto na parte ligada aos poderes de repressão, como nos setores inconformados com o Regime brasileiro, há comportamentos que excedem a própria orientação das instituiçôes". ${ }^{7}$

Alguns dias após D. Avelar Brandão ter ministrado essa conferência, o General Rodrigo Octávio iria ser destituído do cargo de comandante da Escola Superior de Guerra. Esta atitude surpreendeu o próprio prelado, pois ele não via nada de ofensivo na sua fala. Porém, o problema não foi o que ele disse, mas, sim, o fato dele ter distribuído uma cópia de sua conferência aos jornalistas e o impacto que ela teve na imprensa, como ele ficaria sabendo por uma carta reservada da ESG endereçada a ele.

Nesse documento, assinalava-se que, apesar dos militares presentes não terem concordado com as posições defendidas pelo arcebispo, eles entendiam que ele tinha apresentado com "honestidade e patriotismo" o seu ponto de vista. Porém, como o tema era "sujeito a interpretações emocionais", era para ter sido tratado em "caráter reservado". $\mathrm{O}$ autor da carta se disse surpreso ao ter lido nos jornais trechos da conferência que tinha sido distribuído pelo próprio arcebispo aos jornalistas, e afirmava que D. Avelar deixou o comando da ESG "em situação bastante embaraçosa" pela repercussão que teve nos jornais e que foi tratado com "evidente sobrecarga da emocionalidade (sic)". Nessa carta, o autor lembrava ao arcebispo que o "livre debate" era para ter ficado "restrito a Escola [Superior de Guerra]".

D. Avelar Brandão Vilela respondeu ao General Rodrigo Octávio no mesmo dia, dizendo estar surpreso pela repercussão que estava tendo o caso, já que para ele era "uma honra falar na Escola Superior de Guerra". Sobre a publicidade da conferência, ele explicou que "se soubesse que se tratava de documento estritamente reservado, não teria permitido que os repórteres o levassem", e finalizava: "sinto profundamente ter sido causa de desgostos e de

\footnotetext{
${ }^{7}$ Texto A Igreja e o Estado no Brasil (Pasta P-Romano OSB - L. F. Sécrits de Teilhard. Estante 5 - caixa 23. Arquivo LEV/ UCSAL).

${ }^{8}$ Carta Reservada da ESG a D. Avelar. 24 set. 1971. Assinatura ilegível, mas provavelmente do General Rodrigo Otávio. (Pasta Dom Avelar no tempo e na Igreja: fatos importantes de Agosto a Dezembro de 1971. Estante 5 Caixa 24. Arquivo LEV/ UCSAL)
} 
decepçãa" ". D. Avelar ficou tão preocupado com a repercussão do caso que enviou também, no mesmo dia, uma carta para o presidente Médici, com uma cópia da conferência, dizendo não ter pretendido ofender o Exército e que estava "profundamente angustiado", pois não sabia que a conferência era reservada, já que, não tratava "de nenhum assunto proibido". Na carta, percebese que o grande problema para $\mathrm{D}$. Avelar era que esse caso se tornasse o que ele chamou de um "instrumento de traumatismo", ou seja, que fechasse o diálogo entre ele e os militares, pois, para o arcebispo, essa crise não tinha "a mínima razão de ser" ${ }^{\prime \prime}$.

Em 1973, outros dois episódios envolveram D. Avelar Brandão Vilela e o Governo em uma outra crise que também teve uma repercussão nacional. No dia 23 de agosto de 1973, o governador de Pernambuco, Eraldo Gueiros, resolveu outorgar a medalha do Mérito Pernambucano, classe ouro, a D. Avelar. Uma semana depois, sem nenhuma explicação, ele cancelou o ato. Nesse mesmo período, o presidente da Câmara Municipal de Salvador suspendeu a concessão, que seria entregue ao arcebispo, do título de Cidadão da Cidade de Salvador por tempo indeterminado.

D. Avelar considerou esses atos como um desrespeito a ele. E entrou em contato com vários representantes da alta hierarquia militar para tentar resolver o caso. Na documentação pesquisada de D. Avelar Brandão, estava claro qual o motivo dessa atitude dos militares contra o arcebispo: a publicação do documento Eu ouvi os clamores do meu povo.

Este documento foi construído por setores da Igreja Católica nordestina e era um duro ataque aos militares. O Eu Ouvi os Clamores do Meu Povo foi pensado e feito por um grupo de Recife, liderado pelo padre Humberto Plummem, que tinha o apoio de D. Helder Câmara e de um grupo de Salvador formado pelos membros do Centro de Estudos e Ação Social (CEAS), do Mosteiro de São Bento e do grupo Moisés. ${ }^{11}$ Depois deste trabalho concluído,

\footnotetext{
${ }^{9}$ Carta de D. Avelar ao Exmo.sr. Comandante da Escola Superior de Guerra General Rodrigo Otávio. 24 set. 1971. (Pasta Dom Avelar no tempo e na Igreja: fatos importantes de Agosto a Dezembro de 1971. Estante 5 - Caixa 24. Arquivo LEV/ UCSAL)

${ }^{10}$ Carta de D. Avelar ao Excelentíssimo Senhor presidente da República General Emílio Garrastazu Médici. 24 set. 1971. (Pasta Dom Avelar no tempo e na Igreja: fatos importantes de Agosto a Dezembro de 1971. Estante 5 - Caixa 24. Arquivo LEV/ UCSAL)

${ }^{11} \mathrm{O}$ CEAS é uma instituição ligada aos jesuítas, fundada na capital baiana, que se destacou na resistência à ditadura, sendo considerada pelos próprios militares a "principal entidade clerical progressista do Nordeste" (ZACHARIADHES, 2009, p. 98). O mosteiro de São Bento de Salvador, na época, governado pelo abade D. Timóteo Amoroso Anastácio também se destacou na resistência à ditadura militar (CARVALHO NETO, 1996). O grupo Moisés era formado por padres e leigos que se reuniam para se organizarem e promoverem uma resistência conjunta aos militares. (VARÓN; CLAÚDIO, 2001)
} 
ele foi impresso na gráfica beneditina, em Salvador, e começou-se a busca pelas dioceses do Nordeste para que os bispos e Superiores das Ordens religiosas assinassem o manifesto. Os provinciais dos jesuítas da Bahia, Tarcísio Botturi, e o de Recife, Hindenburgo Santana, assinaram o manifesto junto com o abade D. Timóteo Amoroso e o arcebispo D. Helder Câmara. Além deles, mais 14 religiosos (entre bispos e provinciais) assinaram o documento. Porém, muitos se recusaram a assiná-lo, inclusive D. Avelar Brandão Vilela.

O Eu Ouvi os Clamores do Meu povo foi lançado no dia 6 de maio de 1973, no $25^{\circ}$ aniversário da "Declaração Universal dos Direitos do Homem" da Organização das Nações Unidas. Neste documento, setores da Igreja nordestina denunciavam a situação de penúria que passava a maioria da população dessa região. Lembravam que a fome assumia nessa região "características epidemiológicas" e afirmavam que "o subdesenvolvimento continua sendo a nota característica mais importante do Nordeste". Criticavam o "milagre brasileiro" por ter aumentado a concentração de renda no país, defendiam a "propriedade social dos meios de produção" e expressavam uma crítica incisiva aos militares com relação à violação dos direitos humanos. $\mathrm{O}$ Eu ouvi os Clamores do meu povo, "o documento mais radical que uma força política não clandestina jamais ousara publicar desde 1964” (ALVES, 1979, p. 257), denunciava:

A inviolabilidade do lar, o "habeas Corpus", o sigilo da correspondência, as liberdades de imprensa, de reunião e de livre expressão do pensamento, são direitos que foram subtraídos ao povo. A liberdade sindical e o direito de greve foram arrebatados à classe operária. [...]

Para conter resistências a tais condições de opressão e injustiça, a violação desses direitos humanos é excedida por atos de violência ainda maior. $O$ terrorismo oficial instituiu o controle através da espionagem interna e da polícia secreta, recorrendo com freqüência à tortura e ao assassinato. $^{12}$

Este manifesto foi lançado em vários países e teve uma grande repercussão internacional. Os militares se sentiram muito ofendidos por este documento, pela menção à violação dos direitos humanos praticado pelo Governo e, principalmente, por terem sido definidos como Terroristas oficiais (SERBIN, 2001, p. 337).

12 "Eu ouvi os clamores do Meu Povo". Cadernos do CEAS, n. 27, p. 37- 59, out. 1973. (Grifo meu). 
Como já foi dito, D. Avelar foi convidado a assinar o manifesto, porém se negou a fazê-lo por não concordar com o teor dele. Depois que o documento foi lançado, o arcebispo publicou uma nota comentando-o. Nessa nota, o prelado afirmava que o documento manifestava "uma opção religiosa que envolve aspectos de natureza política-social" e que a "Igreja tem o direito e o dever de opinar" nessa questão. Lembrava que o documento fazia denúncias graves e que deveriam ser examinadas "desapaixonadamente". Porém, afirmou: "Não aceito o documento como Diretriz de pastoral Social em minha arquidiocese". ${ }^{13}$

Mas, pelo estilo comedido dessa nota, deu a impressão para setores militares que o arcebispo poderia ter apoiado o documento e ele se preocupou muito com isso. D. Avelar escreveu ao núncio apostólico mostrando o seu parecer sobre o documento e aproveitou para criticar a "linha pastoral" de D. Helder Câmara:

Estou preocupado com a situação reinante aqui no Nordeste.

Como V. Excia. sabe, eu, pessoalmente, não aceito a linha pastoral de Dom Helder, e já tive oportunidade de escrever isso à Nunciatura, antes de V. Excia. chegar ao Brasil.

O documento - Eu Ouvi os Clamores do meu Povo efetivamente ultrapassa os limites do normal.

Mesmo assim contém verdades. Estando eu, aqui no Nordeste, muita gente passou a perguntar-me porque não assinara o documento e o que pensava eu acerca do documento. Chegou [a] um ponto em que devia dizer algo. Teria de medir bem as palavras. Foi o que fiz no pronunciamento entregue à imprensa. [...]

Tenho a impressão que certas Autoridades Militares não compreenderam bem o meu pronunciamento. ${ }^{14}$

Por ter percebido que os militares tinham entendido de forma errada a sua nota, D. Avelar escreveu uma carta ao comandante da 6a Região Militar,

\footnotetext{
${ }^{13}$ Esta nota de D. Avelar foi reproduzida nos jornais A Tarde, Jornal da Bahia e O Estado de São Paulo de 25 ago. 1973.

${ }^{14}$ Carta Excelência Reverendíssima, 31 ago. 1973. (Pasta Assuntos referentes a Títulos e Medalhas - 1973. Estante 5 - Caixa 23. Arquivo LEV/ UCSAL). No índice dessa pasta consta que essa carta foi enviada ao Núncio.
} 
em Salvador, para tentar esclarecer o assunto. $\mathrm{O}$ arcebispo começava a carta afirmando que estava "sentindo, no ar, certas manifestações de desapreço que me deixam preocupado. Minhas relações de respeito e de amizade com as Autoridades Militares e Civis do Estado da Bahia me levam a escrever-lhe esta carta". ${ }^{15}$

Ele afirmou que os militares não tinham entendido a nota dele a respeito do manifesto e que ainda tinha um outro problema que ele tinha que explicar, pois o Eu ouvi os clamores do meu povo tinha "saído de uma tipografia católica" em Salvador. ${ }^{16} \mathrm{Na}$ carta, o arcebispo afirmou discordar do documento por ter "uma visão radical na interpretação da realidade brasileira". ${ }^{17}$

Este episódio envolvendo o Governo e o Cardeal de Salvador, em certo momento, foi proibido de ser veiculado pela grande imprensa, como podemos perceber na cópia de uma censura encontrada no arquivo de D. Avelar:

DE ORDEM SUPERIOR E TENDO EM VISTA MANTER A TRANQUILIDADE NA ÁREA, FICAM PROIBIDAS EXPLORAÇOEES EM TORNO [DO] FATO [DO] CANCELAMENTO [DA] CONDECORAÇÃO [DO] ARCEBISPO DOM AVELAR BRANDÃO, BEM COMO QUAISQUER MANIFESTAÇÕES ATRAVÉS [DA] IMPRENSA ESCRITA, FALADA E TELEVISIONADA, AO REFERIDO PRELADO. ${ }^{18}$

D. Avelar Brandão, por ter se sentido humilhado publicamente com as atitudes tomadas contra ele, resolveu não comparecer à Parada Militar de 7 de Setembro daquele ano. Porém, fez questão de explicar para cada representante das três Forças Armadas, em Salvador, o motivo da sua ausência. D. Avelar, com isso, pretendia que esse seu ato, de forma alguma, fosse entendido pelos

\footnotetext{
${ }^{15}$ Idem

${ }^{16}$ Essa passagem demonstrava que os militares não entendiam a estrutura da Igreja Católica, pois, como foi dito, esse manifesto foi impresso na gráfica beneditina, em Salvador. O abade do Mosteiro de São Bento não precisava da autorização de D. Avelar para tal medida, pois, ele não deve obediência ao arcebispo. Por isso, mesmo que o documento tenha sido impresso em uma "tipografia católica" em Salvador, isso não queria dizer que tivesse a participação de D. Avelar, como chegaram a suspeitar os militares.

${ }^{17}$ Carta ao General Heitor Fontoura de Morais. Comandante da Sexta Região Militar. 31 ago. 1973. (Pasta Assuntos referentes a Títulos e Medalhas - 1973. Instante 5 - Caixa 23. Arquivo LEV/ UCSAL).

${ }^{18}$ Censura Federal. Sem data. (Pasta Assuntos referentes a Títulos e Medalhas - 1973. Estante 5 - Caixa 23. Arquivo LEV/ UCSAL)
} 
militares como um fechamento definitivo ao diálogo, como ele deixou claro ao comandante da 6a Região Militar: "o meu não comparecimento a esta Parada não significa qualquer modificação no meu comportamento posterior, relativamente ao modo cordial e social como nos vínhamos tratando". ${ }^{19}$

D. Avelar escreveu para vários militares para tentar de toda a forma demonstrar que ele não aprovava o documento Eu ouvi os Clamores do Meu povo. O general Antônio Carlos Muricy (de quem D. Avelar era amigo) afirmou ao arcebispo que estava tentando provar que o seu pronunciamento sobre o documento não era "um ato de luta e sim o de indicar a conveniência de um estudo do que lá se contém [...] sem que com isso o Sr. esteja confirmando ou desmentindo o que está escrito". ${ }^{20} \mathrm{D}$. Avelar Brandão respondeu ao general avisando que ele estava sendo tratado, nesse "episódio desagradável", de maneira "muito rude e violenta", mas que mesmo assim, estava procurando agir "com muita prudência e dignidade" para que não ocorresse "uma comoção em nossos meios religiosos". ${ }^{21}$

Para que não ficasse nenhuma dúvida a respeito de sua posição, D. Avelar Brandão Vilela lançou um outro documento chamado A legítima interpretação do meu parecer sobre o documento: 'Eu ouvi os clamores do meu povo', onde ele recordava que o manifesto da Igreja nordestina fazia denúncias graves e que deveriam ser estudadas por pessoas "de comprovada competência intelectual e moral", mas reafirmava que não aceitava o documento por ser radical e considerava "o diálogo um instrumento valioso de comunicação". ${ }^{22}$

Mesmo nesse momento de crise que envolveu D. Avelar e certos setores das Forças Armadas, em que ele mesmo expressou que estava sendo desmoralizado publicamente, em momento algum o arcebispo fechou as portas para o diálogo com os militares. Ele tentou resolver o impasse com a alta hierarquia militar, evitando que ocorresse um rompimento definitivo. E finalmente, em 1974, o arcebispo D. Avelar receberia o título de "Cidadão de Salvador".

\footnotetext{
${ }^{19}$ Carta ao General Heitor Fontoura de Morais. Comandante da Sexta Região Militar. 7 set. 1973; Carta ao Major Brigadeiro Alberto costa Matos. Comandante do Comando Costeiro. 7 set. 1973; Carta ao Almirante Ernesto Mourão Sá. Comandante do $2^{\circ}$ distrito Naval. 7 set. 1973. (Pasta Assuntos referentes a Títulos e Medalhas - 1973. Estante 5 - Caixa 23. Arquivo LEV/ UCSAL).

${ }^{20}$ Carta do general Antônio Carlos da Silva Muricy a S. Eminência D. Avelar Brandão vilela. 12 set. 1973. (Pasta Assuntos referentes a Títulos e Medalhas - 1973. Estante 5 - Caixa 23. Arquivo LEV/ UCSAL).

${ }^{21}$ Carta de D. Avelar Brandão Vilela ao prezado General Antônio Carlos Muricy. 17 set. 1973. (Pasta Assuntos referentes a Títulos e Medalhas - 1973. Estante 5 - Caixa 23. Arquivo LEV/ UCSAL).

${ }^{22}$ A legítima interpretação do meu parecer sobre o documento: "Eu Ouvi os Clamores do Meu Povo" 17 set. 1973. (Pasta Assuntos referentes a Títulos e Medalhas - 1973. Estante 5 - Caixa 23. Arquivo LEV/ UCSAL).
} 
Durante a ditadura, D. Avelar manteve uma relação muito próxima com os militares e, em vários momentos, celebrou missas nas comemorações das Forças Armadas (essa atitude era evitada por vários bispos, para que não fosse visto como um apoio ao Regime). A título de exemplo, em 1977, D. Avelar celebrou missa na Catedral Basílica "pelo aniversário da Revolução" ${ }^{23}$ e alguns meses depois, celebrava missa em homenagem "à semana do exército". ${ }^{24} \mathrm{O}$ arcebispo de Salvador evitava apoiar os documentos publicados pelo episcopado nacional que criticavam o Governo, e que com isso pudesse comprometê-lo com os militares. Quando foi lançado o documento Não oprimas Teu irmão, após o assassinato do jornalista Wladimir Herzog pelas Forças de Segurança, em que o episcopado paulista condenava a violação dos direitos humanos, D. Avelar preferiu o silêncio. ${ }^{25}$

D. Avelar Brandão fazia parte da comissão Bipartite, formada por membros do episcopado nacional e dos militares para tentar amenizar os conflitos entre o Governo e a Igreja Católica devido a repressão contra os setores católicos que faziam oposição ao Regime militar. Foram mantidos encontros informais entre as cúpulas das Forças Armadas e da Igreja Católica, entre 1970 a 1974, no intuito de reduzir as tensões entre as duas instituições (SERBIN, 2001).

Parece indiscutível que D. Avelar pretendeu manter sempre o diálogo com os militares, porém não se pode deduzir que, por isso, ele apoiava a ditadura e ponto final, pois seria cair numa simplificação. Os setores da esquerda também viam em D. Avelar Brandão Vilela alguém em quem poderia se socorrer quando se precisava de ajuda durante a ditadura militar.

\section{Avelar e as esquerdas}

O Movimento Estudantil recorreu ao Cardeal de Salvador, em algumas ocasiōes, para que ele intercedesse em prol dos alunos. Quando, em 1975, ocorreu uma greve de grande proporção na Universidade Federal da Bahia (UFBA) que quase parou a universidade por completo (esta paralisação é considerada como a $1^{\text {a }}$ grande greve estudantil depois de 1968) e os estudantes se

\footnotetext{
23 "Missa na Catedral pelo aniversário da revolução". Tribuna da Bahia, p. 3, 1 abr. 1977.

24 “Missa deu início ontem a semana do Exército”. Diário de Notícias, p. 3, 20 ago. 1977.

25 “Dom Avelar não opina sobre documento da CNBB". Tribuna da Bahia, p. 3, 3 dez. 1975. Publicado também pelo CEAS. Ver: "Não Oprimas teu irmão". Caderno do CEAS, n. 41, p. 71-73, jan./fev. 1976.
} 
viram com problemas com o Governo e a Reitoria da Universidade ${ }^{26}$, eles foram pedir a D. Avelar para intermediar as negociações, o qual prontamente aceitou. ${ }^{27}$

Sabendo da proximidade do arcebispo de Salvador com a alta hierarquia militar, em vários momentos durante a ditadura, os presos políticos e familiares procuraram D. Avelar Brandão para denunciarem os maus tratos, as prisões indevidas, as torturas que sofriam e pedindo ao Cardeal para interceder por eles. O prelado de Salvador sempre esteve aberto para tentar intermediar as negociações entre os militares e os prisioneiros políticos. Segundo Emiliano José, um ex-preso político, D. Avelar era "um solidário amigo dos presos políticos" (JOSÉ, 2006, p. 12).

Por exemplo, dos dias 4 a 11 de julho de 1975, os órgãos de repressão iniciaram uma perseguição a pessoas que estavam sendo acusadas de tentarem reorganizar o Partido Comunista Brasileiro (PCB) na Bahia, era a chamada Operação Radar. Vários cidadãos foram detidos, dentre outros, Sérgio Santana, vereador do Movimento Democrático Brasileiro (MDB); Marco Antônio Rocha Medeiros, diretor do Clube de Engenharia da Bahia; Ieda Santana, assessora do Derba e Roberto Argolo, professor do Departamento de Física da UFBA. Com a possibilidade da prisão preventiva ser decretada para os acusados, os familiares foram procurar D. Avelar, pedindo para interceder junto a VI Região Militar, e entregaram-no o seguinte documento, transcrito pela imprensa:

Eminentíssimo Dom Avelar Brandão Vilela - D.D. Cardeal Arcebispo Primaz do Brasil.

O momento que atravessamos é de angústia, apreensão e dor.

Conforta-nos a esperança de saber que o 'cristianismo é uma mensagem de amor, de justiça, de liberdade, de responsabilidade' [...]

As famílias dos presos políticos apelam para a Grandeza das suas açôes, a fim de interferir junto à Auditoria da VI Região Militar no sentido de evitar que sejam tomadas

\footnotetext{
${ }^{26}$ Um líder estudantil comentou como foi tratada esta greve pelas autoridades: "As unidades da UFBA foram ocupadas por tropas do Exército [...] Muitos líderes tiveram que fugir de Salvador, pois passaram a ser caçados pela repressão" (BENEVIDES, 1999, p. 91).

${ }^{27}$ Entrevistas com Gabriel Kraychete (26 out. 2006), Elsa Kraychete (1 dez. 2006) e Ana Cecília Bastos (10 jan. 2007).
} 
medidas de prisão preventiva, em virtude das pessoas implicadas serem cidadãos que têm residência fixa, profissão definida, conduta irrepreensível, atestadas inclusive pelas próprias associações profissionais a que estão vinculados $[\ldots]$

Confiamos no seu amor ao homem!

Estamos certos de que em nome de Cristo, usará de toda sua força interior, a fim de evitar que injustiças maiores sejam consumadas.

Que o Deus da Esperança ilumine cada vez mais as suas ações, abençoe as suas palavras, os seus pensamentos.

Curvamo-nos diante da sua grandeza!

Salvador, 25 de julho de $1975 . .^{28}$

O arcebispo, também, enviava correspondências para os comandantes militares querendo saber sobre o tratamento dado aos prisioneiros políticos. Em um telegrama dele para o comandante da $6^{a}$ Região Militar, ele queria saber sobre o tratamento dado aos presos políticos a pedidos de "um grupo de esposas e mães”. O general Heitor Fontoura de Moraes respondeu ao Cardeal dizendo que o Exército não era o responsável pelos detentos nos presídios, e informou a D. Avelar que não existiam prisioneiros políticos na Bahia e sim "julgados e condenados, regularmente pela Justiça, por assassínio, terrorismo e subversão da ordem legal”. O Cardeal treplicou respondendo que iria procurar o setor responsável pelos presídios para saber mais informaçōes sobre os presos, e ironicamente pediu desculpas por ser "um ignorante" e não saber diferenciar um preso político de um preso com a alcunha dada pelo General. ${ }^{29}$

O Cardeal apoiou os encontros nacionais que ocorreram em Salvador, promovidos pelas esquerdas, em defesa da Anistia, em 1978 e 1979. Tanto o "I ${ }^{\circ}$ Encontro Nacional dos Movimentos de Anistia e Direitos Humanos", que ocorreu no CEAS, em 1978; quanto o "II Congresso Nacional pela Anistia",

\footnotetext{
28 "Arcebispo vai interferir em favor dos presos políticos". Jornal da Bahia, p. 3, 26 jul. 1975. Segundo o jornal este documento foi entregue pelos familiares dos presos políticos ao Cardeal e continha 90 assinaturas.

${ }^{29}$ Telegrama do Eminentíssimo e reverendíssimo Cardeal de São Salvador da Bahia ao Excelentíssimo Sr. Comandante da VI Regiāo Milita ( 6 set. 1973), Telegrama do General de Brigada Heitor Fontoura de Moraes, comandante da VI Região Militar ao Eminentíssimo Sr. Cardeal de Salvador/ Bahia (12 set. 1973) e Telegrama do Cardeal de São Salvador primaz do Brasil ao Excelentíssimo Sr. General de Brigada Heitor Fontoura de Moraes (12 set. 1973)) . (Pasta Assuntos referentes a Títulos e Medalhas - 1973. Estante 5 - Caixa 23. Arquivo LEV/ UCSAL)
} 
que ocorreu no Colégio 2 de Julho, em 1979, onde compareceram vários exexilados políticos, tais como Luis Carlos Prestes, Diógenes Arruda, Apolônio de Carvalho, entre outros, tiveram as bênçãos do prelado. ${ }^{30}$

Os setores da Igreja Católica que faziam oposição aos militares viam em D. Avelar Brandão um aliado contra a repressão militar. O abade do Mosteiro de São Bento, um dos principais opositores aos militares na Bahia, sempre que precisava, encontrava apoio em D. Avelar. ${ }^{31} \mathrm{O}$ padre italiano Renzo Rossi, que visitava os prisioneiros políticos em todo o país, servindo como um elo de ligação entre os presos e a sociedade, levando as denúncias de violação dos direitos humanos praticados pelos militares, no Brasil e no exterior, tinha total apoio do prelado (JOSÉ, 2002). ${ }^{32}$

O bom relacionamento que D. Avelar procurava manter com as Forças Armadas permitia a ele ter um grande espaço de manobra para interceder em defesa dos religiosos que trabalhavam em sua diocese e, principalmente, conseguir protegêlos contra a repressão militar. Quando os militares tentaram expulsar os jesuítas do CEAS, Cláudio Perani e Andrés Mato, D. Avelar tomou a frente das negociações, defendendo os dois sacerdotes.

No dia 28 de outubro de 1978, o coordenador do CEAS, o jesuíta italiano Cláudio Perani estava voltando de uma viagem à Europa e foi detido e impedido de deixar o aeroporto Os policiais disseram que o nome dele constava em uma lista de 1500 pessoas proibidas de regressar ao Brasil. A Polícia Federal queria que o padre retornasse imediatamente para a Itália na mesma aeronave. Cláudio Perani conseguiu avisar da sua detenção a um jesuíta que o esperava, que tratou logo de avisar D. Avelar Brandão para informar do ocorrido e para pedir ajuda para uma solução do problema.

Quando ficou sabendo do ocorrido, o Cardeal de Salvador foi pessoalmente ao aeroporto para buscar o sacerdote. Chegando lá, tratou de entrar em contacto com o superintendente da Polícia Federal. Depois de cinco horas detido no aeroporto, o padre Perani pôde sair junto com D. Avelar. A Polícia Federal alegou, naquele momento, que tinha sido um "equívoco" a detenção

\footnotetext{
${ }^{30}$ Entrevista com Joviniano Carvalho Neto (24 out. 2006) e "Anistia: liçōes e lembranças". Tribuna da Bahia, p. 2,4 ago. 1999. Para mais informações sobre o II ${ }^{\circ}$ Congresso da Anistia e do apoio de D. Avelar a este evento, ver o artigo de Joviniano Neto, “O II ${ }^{\circ}$ Congresso da Anistia: Momento de Resistência e Definiçôes” contido neste livro.

${ }^{31}$ Entrevista com D. Bernardo em 30 out. 2008

${ }^{32}$ D. Avelar definiu a atuação do padre Renzo com os presos políticos e com os seus familiares como um "apostolado", e afirmou que o sacerdote "merece, por isso mesmo, o nosso aplauso, pela maneira evangélica de realizar a sua missão". Dados disponíveis em: <http://www.emilianojose.com.br/renzo/index_popup.htm>. Acesso em: 27 dez. 2008.
} 
do jesuíta, fruto de uma confusão nos nomes. ${ }^{33}$ Ao chegar à sede do CEAS e receber o apoio dos colegas, o padre Cláudio Perani concedeu uma entrevista coletiva para comentar o caso, e concluiu: "Eu tenho amigos importantes, mas fico imaginando o que ocorre com os operários e camponeses que enfrentam estas situaçōes sem ninguém a olhar por eles. Foram horas angustiantes as que passei". ${ }^{34}$

Menos de um ano após o ocorrido com Cláudio Perani, mais um jesuíta do CEAS sofreria ameaça de expulsão. Dessa vez foi o padre espanhol Manuel Andrés Mato. Quando o padre Andrés foi à superintendência da Polícia Federal para pegar um visto de saída do Brasil para viajar ao Peru, onde iria participar de um congresso dos jesuítas, tomou conhecimento de que tinha sido instaurado um inquérito visando sua expulsão do país.

Imediatamente o provincial dos jesuítas, Dionísio Sciuchetti, tratou de entrar em contato com D. Avelar Brandão, para pedir a intercessão do Cardeal. Com a intervenção de D. Avelar Brandão Vilela que entrou em contato diretamente com o então ministro da Justiça, Petrônio Portella, foi encerrado o inquérito sobre a expulsão do jesuíta Andrés Mato. ${ }^{35}$ Tanto no caso da tentativa de expulsão do padre Perani quanto na do padre Andrés foi fundamental a interferência do Cardeal de Salvador, que teve uma atitude enérgica em defesa dos dois sacerdotes.

\section{À maneira de conclusão}

Em uma carta de D. Avelar enviada ao Núncio Apostólico, o Cardeal definiu sua atuação durante a ditadura militar perante o Governo e os seus opositores:

Costumo respeitar as autoridades para também ser respeitado. Mantenho boas relaçōes, há programas de mútua colaboração, quando se trata do bem comum. Não

\footnotetext{
33 "Detenção de jesuíta não passou de um 'equívoco”. Tribuna da Bahia, p. 3, 30 out. 1978.

34 “D. Avelar e cel. Ludwig no caso do padre detido". Jornal da Bahia, p. 3, 29 out. 1978. O padre Perani recebeu depois uma carta de apoio com dezenas de assinaturas, iniciada pela de D. Avelar Brandão, encorajando-o: "Queremos dizer-lhe que estamos a seu lado" e pedia a ele para continuar buscando a "força que vem da palavra do Deus que liberta”. (ZACHARIADHES, 2009, p. 95)

${ }^{35}$ O próprio superintendente da Polícia Federal de Salvador, Hélio Romão, confirmou que o processo de expulsão contra o padre Andrés tinha sido encerrado depois das negociaçôes feitas por D. Avelar com as autoridades e que tinham sido conduzidas "num nível muito elevado" pelo arcebispo. "Polícia Federal nega ter feito intimação ao padre Manoel Mato”. A Tarde, p. 2, 3 out. 1979.
} 
quero a Igreja comprometida com o Governo e a sua realidade. Também não aprovo tomadas de caráter contestatório, como se a Igreja fosse um partido de oposição. Considero sagrada a liberdade da Igreja. E, para isso não deve estar desafiando o Governo, a qualquer preço. Conservo as energias para aquelas causas que realmente exigem definições e até reprovações. Mas não faço isto como se fosse um inimigo, mas um Pastor que deixa sempre aberta as portas do diálogo. Dentro destes princípios nos mantemos e procuramos evitar de ser manipulados seja pelo Governo, seja pela oposição. ${ }^{36}$

Durante a ditadura militar, D. Avelar Brandão Vilela procurou ser um mediador entre o Governo e os setores da sociedade que estavam na oposição, tentando administrar os conflitos sociais e políticos durante aquele período. Consciente da sua posição de arcebispo, procurou transitar pelos diversos grupos políticos, deixando a porta aberta para todos. Debaixo do rótulo de "moderado", escondia-se um arcebispo extremamente hábil politicamente, e que fazia do diálogo sua maior arma.

\section{REFERENCIAS}

ALVES, Márcio Moreira. A Igreja e a política. São Paulo: Brasiliense, 1979.

BENEVIDES, Silvio C. S. Proibido proibir: uma geração na contramão do poder. Dissertação (Mestrado em Ciências Sociais) - Faculdade de Filosofia e Ciências Humanas, Universidade Federal da Bahia, Salvador, 1999.

CARVALHO NETO, Joviniano (Org.). D. Timóteo presença histórica. Salvador: [s.n.], 1996.

EU OUVI os Clamores do Meu Povo. Cadernos do CEAS, Salvador, n. 27, p. 38-60, out. 1973.

JOSÉ, Emiliano. As asas invisiveis do Padre Renzo. São Paulo: Casa Amarela, 2002.

. Esquecer jamais. In: GUEDES, Ana; MENDONÇA, Lucimar Silva Cunha. (Org.). Construindo a memória: a luta pela anistia na Bahia, 2006. p. 7-15.

NÃO OPRIMAS teu irmão. Cadernos do CEAS, Salvador, n. 41, p. 71-73, jan./fev. 1976.

\footnotetext{
${ }^{36}$ Carta de D. Avelar ao Prezado Sr. Núncio Apostólico D. Cármine Rocco. 8 maio 1980. (Envelope sem referência. Estante 5 - Caixa 26. Arquivo LEV/ UCSAL).
} 
SERBIN, Kenneth P. Diálogos na sombra: Bispos e militares, tortura e justiça social na ditadura. São Paulo: Companhia das Letras, 2001.

VARÓN, Paloma; CLAÚDIO, Francisco. Rumo a terra prometida: a trajetória do grupo Moisés. Monografia (Graduação em Comunicação) - Faculdade de Comunicação, Universidade Federal da Bahia, Salvador, 2001.

ZACHARIADHES, Grimaldo Carneiro. CEAS: Jesuitas e o Apostolado Social durante a Ditadura Militar. Salvador: EDUFBA, 2009. 1 dez. 2008.

. Dom Avelar Brandão Vilela: O bispo do diálogo. Jornal São Salvador, Salvador,

\section{ENTREVISTADOS}

Ana Cecília Bastos (10-01-2007).

Antônio Ferreira Guerreiro de Freitas (31-10-2006).

Dom Bernardo (30-10-2008).

Elsa Kraychete (1-12-2006).

Gabriel Kraychete (26-10-2006).

Joviniano Carvalho Neto (24-10-06) e (07-02-2007).

Monsenhor Ademar Dantas (13-10-2008).

Monsenhor Gaspar Sadock (10-06-2008).

Monsenhor Walter Magalhães (7-11-2008).

Padre André Seutin (21-10-2008).

Padre Francisco Xavier Barturen (09-10-2006).

Yvette Amaral (10-10-2008). 


\section{No meio do caminho tinha uma} Jornada, ou era ela o caminho?

\section{Jornadas de Cinema da Bahia (1972-1978)}

Izabel de Fátima Cruz Melo ${ }^{1}$

Enquanto a década de 60 constituiu-se como um momento de rupturas e transformaçóes no cinema brasileiro, de modo geral, a década de 70 inaugura outro tempo de tentativa de continuidade, de garantir a existência da produção cinematográfica, a partir do acionamento de um capital simbólico, que tenta reconhecer pontos positivos, mas sem perder a perspectiva crítica, como é possível apreender das análises da história e historiografia do cinema brasileiro (GOMES, 2002; XAVIER, 2001). Compreendemos o surgimento das Jornadas de Cinema da Bahia como parte desse esforço de criação e manutenção das atividades cinematográficas na Bahia e no Brasil, pois, através delas, o cinema baiano gestou novas iniciativas de produção, especialmente através de uma nova geração que se iniciou na prática cinematográfica, a partir das suas atividades e onde o cinema brasileiro encontrou espaço para as discussóes organizacionais e políticas, de modo menos exposto à ação da censura.

Foi justamente na transição entre as décadas, em 1968, que Walter da Silveira e Guido Araújo iniciaram as atividades do Grupo Experimental de

${ }^{1}$ Licenciada em História pela Universidade Católica do Salvador (UCSAL); Especialista em História da Bahia pela Universidade Estadual de Feira de Santana (UEFS); Mestre em História Social pela Universidade Federal da Bahia (UFBA). 
Cinema (GEC). Através deste, parecia se realizar o desejo do reconhecimento do cinema enquanto atividade artística pela universidade, debate que já ocupava as páginas da imprensa desde o período do reitorado de Edgard Santos (Cf. CARVALHO, 1999). O Curso de Cinema do GEC tinha como principal objetivo formar equipes qualificadas para o trabalho em películas de $16 \mathrm{~mm}$, para a produção de documentários. Era organizado a partir de dois módulos principais, o de Estética do Cinema, ministrado pelo crítico Walter da Silveira, e Teoria e Prática Cinematográfica, por Guido Araújo, que seriam provavelmente complementados pelos módulos de Direção, Argumento e Roteiro e de Fotografia e Som. ${ }^{2}$ O GEC tornou-se importante no panorama do período, porque muitos dos seus alunos, efetivamente, tornaram-se realizadores inseridos na atividade cinematográfica baiana. Um exemplo disso seria o André Luiz Oliveira, diretor de Meteorango Kid.

Contudo, com a chegada do mês de dezembro de 1968, com o AI- $5^{3}$, as atividades do GEC, assim como de grande parte de núcleos de atividades artísticas e culturais, como se dizia no período, ficaram comprometidas. Por isso, segundo Guido Araújo, era necessário mudar de estratégia. O Grupo Experimental teve dificuldades de manter-se, assim como as atividades cineclubistas, que no Brasil, de uma maneira geral, foram desarticuladas em consequência do Ato Institucional. Entretanto, mesmo com as dificuldades da conjuntura, as atividades cinematográficas soteropolitanas não cessaram. Em 1971, ocorre no Cine Bahia a retrospectiva dos 10 anos do cinema baiano de longa metragem, que buscava homenagear a produção do Ciclo Baiano de Cinema, através dos 10 anos de lançamento da "Grande Feira", de Roberto Pires, "que foi realmente o primeiro grande filme baiano com grande êxito". ${ }^{4}$

Ainda segundo a narrativa de Guido, importante porque através dela conseguimos mapear as diversas influências que contribuíram para o surgimento da Jornada, a retrospectiva do cinema baiano teve como uma das suas principais consequências reunir diretores, produtores e demais interessados em cinema, numa perspectiva de rearticulação, que foi repetida na mostra dos 10 anos do Festival de Oberhausen, que ocorreu no Cine Rio Vermelho, em 1971. Essa mostra foi trazida para Salvador através de uma associação entre o Clube

\footnotetext{
2 "Estética e prática do cinema serão programa do Grupo Experimental”. Jornal Universitário, Salvador, p. 3, fev. 1968. Escritório da Jornada Internacional de Cinema da Bahia. Pasta de recortes.

${ }^{3}$ Em 13 de dezembro de 1968, foi perpetrado pelo presidente Gal Costa e Silva Ato Institucional n ${ }^{\circ}$, que ocasionou um endurecimento significativo na repressão. Retirando, entre outras coisas, o direito de habeas corpus e todas as garantias constitucionais dos cidadãos. (Cf. ANDRADE, 1991, p. 788-791)

${ }^{4}$ Entrevista concedida por Guido Araújo no Escritório da Jornada Internacional de Cinema da Bahia, em 20 de dezembro de 2007.
} 
de Cinema da Bahia, o Instituto Goethe e a Cinemateca do MAM do Rio de Janeiro. Segundo Guido Araújo, é dessa experiência de mostras e retrospectivas que surge a ideia de montar a Jornada, para movimentar a cena cinematográfica baiana com um espaço que estimulasse a produção e o debate sobre cinema baiano e brasileiro. ${ }^{5}$

Assim, num estado onde a produção de longas-metragens estava praticamente paralisada devido às dificuldades de criação/inserção dos filmes em um mercado cinematográfico que ocasionaram o êxodo de diversos realizadores como Glauber Rocha, Roberto Pires e Olney São Paulo para o Sudeste, aumentadas ainda pela ascensão da ditadura - o caminho que parecia possível para rearticular a continuidade da produção era o curtametragismo, pois exigiria menos investimentos e possibilitava o exercício de criatividade do seu autor.

Então quando eu fui pra fazer a jornada, já foi com esse propósito, em primeiro lugar, em termos de Bahia, e mesmo fora da Bahia, naquele momento, a possibilidade de fazer alguma coisa mais viável em cinema - e com seriedade, porque em termos de longa-metragem, além das amplas dificuldades cultivadas pela ditadura [...] é, quer dizer, não havia chance de fazer nada [...]

Não tinha mercado, o apoio que o governo dava não era para esse tipo de filme, e no mais, quem quisesse fazer um filme mais sério, estava sempre ameaçado pela censura, essa coisa toda. Então isso foi fundamentalmente [...] bom, também não deixa de ter tido a influência, mesmo que indireta, o fato do Festival de Oberhausen. Porque eu não nego, o primeiro festival que, de uma maneira ou outra, exerceu uma influência sobre a Jornada e com a qual a Jornada teve uma ligação mais profunda, foi o Festival de Oberhausen, que era um festival de curta-metragem. Então todos esses fatores influenciaram. ${ }^{6}$

O Festival de Oberhausen é uma mostra de filmes de curta-metragem que acontece na Alemanha desde 1954 e ficou conhecido como um dos principais

\footnotetext{
${ }^{5}$ Ibidem. Cf. JORNADA BAIANA DE CURTA METRAGEM. Regulamento. 1972. Setor de Cinema da Faculdade de Comunicação da Universidade Federal da Bahia. Caixa Jornada 1972 e "A palavra do organizador". Jornal da Bahia, p. 13, 7 jan. 1972. Caderno 2 Estudantil . Biblioteca Central do Estado da Bahia. Setor Hemeroteca. Maço Jornal da Bahia Janeiro de 1972.

${ }^{6}$ Entrevista concedida por Guido Araújo no Escritório da Jornada Internacional de Cinema da Bahia, em 20 de dezembro de 2007.
} 
festivais de vanguarda do mundo, sempre aberto para inovações estéticas, temáticas e de linguagem, sendo inclusive o espaço onde os participantes do novo cinema alemão surgiram. O Festival aparece em diversos momentos da fala de Guido, como inspirador do formato das Jornadas, especialmente no tocante à preferência pelo formato curto, cabível dentro da realidade da atividade cinematográfica baiana. Assim, gestada pelo panorama sociocultural de duas décadas, surge em Salvador, no mês de janeiro de 1972, a I Jornada Baiana de Curta-Metragem.

As Jornadas consistiam, inicialmente, segundo seus organizadores, num evento em que ocorriam diversas atividades relacionadas com a prática cinematográfica no Brasil e na Bahia e suas diversas implicações culturais, sociais e políticas, especialmente ligadas à produção do curta-metragem. Iniciou-se como a I Jornada Baiana de Curta Metragem, em 1972; em 1973, acontece a II Jornada Nordestina de Curta Metragem; em 1973 e em 1974, passa a ser a III Jornada Brasileira de Curta- Metragem. Desde a década de 80, ela se tornou conhecida como Jornada Internacional de Cinema da Bahia.

Neste momento, buscamos construir um mapeamento inicial das atividades das Jornadas de Cinema da Bahia, entre os anos de 1972-78, período no qual ela ocorreu em Salvador, e que nos interessa por possibilitar uma futura correlação do certame com a ambiência sociocultural soteropolitana. Através dele, esforçamo-nos para entender como o evento se organizou durante as sete edições que compõem o nosso recorte, seguindo suas ambições iniciais e seus desdobramentos. De modo geral, procuramos seguir ediçōes das Jornadas e suas as atividades como um modo de aproximação deste universo que reunia pessoas com diferentes compreensões da atividade cinematográfica. $\mathrm{O}$ eixo das Jornadas consistia num bloco de atividades frequentes anualmente, de modo que é possível acompanhar sua ocorrência pelos seus regulamentos e programas. Elas consistiam basicamente na mostra competitiva em que eram exibidos os filmes selecionados para concorrer à premiação; debates que ocorriam após a exibição dos filmes; mostras paralelas, que poderiam ter diversos motes, geralmente homenageando algum realizador ou seguindo temáticas específicas; seminários e simpósios objetivando discutir a "problemática do curtametragem" em seus diversos matizes e acepçôes.

\section{Jornada Baiana de Curta-Metragem (13 a 16 de janeiro de 1972)}

A primeira Jornada Baiana surgiu em Salvador, num momento de estagnação da produção cinematográfica na Bahia e se propunha a "incentivar entre a juventude baiana a comunicação artística através da imagem cinematográfica e contribuir para que se abram melhores perspectivas para o curta-metragem 
na Bahia e no Brasil"” . Para isto, a programação foi pensada de modo a tocar em pontos considerados essenciais para o desenvolvimento do cinema, especialmente de curta-metragem. Assim, a Jornada foi composta pela Mostra Competitiva, restrita a filmes baianos (ARAÚJO, 1972, p. 13), Mostra Informativa que contou com filmes de diversos estados e de temáticas variadas e também o Simpósio sobre o Curta-Metragem, composto por quatro diretrizes centrais; "Situação do curta-metragem no Brasil e sua situação com o INC", "Perspectivas de profissionalização do super-8", "O impasse do curta-metragem na Bahia" e "O mercado de TV para o curta-metragem".

A instituição promotora do evento foi o Grupo Experimental de Cinema (GEC), através da Coordenação de Extensão da UFBA, tendo como diretor Valentin Calderón, e como coordenador o cineasta e também coordenador do GEC Guido Araújo. Os espaços ocupados pela I Jornada foram a Biblioteca Central do Estado, nos Barris, a Reitoria da UFBA e o Instituto Cultural Brasil-Alemanha (ICBA).

Através do Regulamento da I Jornada Baiana de Curta-Metragem, é possível obter indícios de quais eram as possibilidades de criação cinematográfica naquele período. De início, o que nos chama atenção é que o evento centra suas atenções no cinema de curta-metragem ${ }^{8}$, especialmente nas bitolas ${ }^{9}$ de 16 $\mathrm{mm}$ e super- $8^{10}$. A escolha pela forma curta advém da percepção de que seria mais fácil fomentar a produção, visto que com a menor duração do filme, o custo de realização seria mais baixo - e justamente por isso seria o tipo de produção cinematográfica que teria potencial para atrair os jovens e abrir possibilidades de experimentações estéticas e de conteúdo ${ }^{11}$. Esta postura não era exatamente inovadora, pois pode ser interpretada como uma continuidade da proposta do GEC, que desde a sua criação, propunha laboratórios de prática cinematográfica em $16 \mathrm{~mm} .{ }^{12}$

\footnotetext{
${ }^{7}$ Jornada Baiana de Curta- Metragem. Regulamento. 1972. Setor de Cinema da Faculdade de Comunicação da Universidade Federal da Bahia. Caixa Jornada 1972; Jornada Baiana de Curta-Metragem. Programa. 1972. Biblioteca Paulo Emílio Sales Gomes- Cinemateca Brasileira. Pasta F151(81) Salvador.

${ }^{8}$ Curta-metragem é um filme que pode ser de diversas bitolas e gêneros, que tem duração máxima de 30 minutos.

${ }^{9}$ Chama-se de bitola a largura da tira da película. (Cf. SALLES, [2007a])

${ }^{10}$ A bitola de $16 \mathrm{~mm}$ foi criada na década de 1920 , como opção mais barata que a $35 \mathrm{~mm}$. A bitola super- 8 foi criada na década de 1960, a partir de modificaçóes implementadas na $8 \mathrm{~mm}$, que já era, por sua vez, uma alternativa mais em conta que a $16 \mathrm{~mm}$. (Cf. SALLES, [2007b])

${ }^{11}$ Entrevista concedida por Guido Araújo no Escritório da Jornada Internacional de Cinema da Bahia, em 20 de dezembro de 2007

12 “Estética e prática do cinema serão programa do Grupo Experimental”. Jornal Universitário, Salvador, p. 3, fev. 1968. Escritório da Jornada Internacional de Cinema da Bahia. Pasta de recortes.
} 
Assim, para a mostra competitiva, aberta para filmes em $16 \mathrm{~mm}$ e super8 , houve a inscrição de oito ${ }^{13}$ filmes em $16 \mathrm{~mm}$, que segundo o júri foram premiados sem "levar em conta o caráter classificatório da competição e, objetivando incentivar os realizadores e levando em conta as dificuldades materiais e técnicas que tiveram para realizar seus filmes, decidiu dar a premiação por ordem alfabética”. (TAVARES, 1978, p. 9)

Ou seja, por reconhecer as dificuldades de realização dos filmes, o júri seguiu a diretriz do regulamento, buscando estimular a produção, com a premiação de todos os filmes. O interessante é que os prêmios outorgados foram em grande parte em material cinematográfico, o que proporcionaria ao ganhador nova oportunidade de criação, tais como câmera super-8, fotômetro, película virgem, entre outros. ${ }^{14}$

Por sua vez, a Mostra Informativa foi formada por onze filmes em $35 \mathrm{~mm}$ e $5 \mathrm{em} 16 \mathrm{~mm}$. As temáticas eram em grande parte nordestinas, mas não exclusivamente baianas, além de dois filmes relativos à vivência universitária. A finalidade dessa mostra era servir de panorama da produção de curtametragem nacional, atualizando os participantes da Jornada Baiana no sentido das produções cinematográficas brasileiras.

O Simpósio sobre o Curta-Metragem foi um momento para que os cineastas conseguissem sistematizar suas críticas, necessidades e sugestôes de resoluções de modo a constituir um documento chamado "Resoluções do Simpósio da I JBCM". ${ }^{15}$ Neste, os cineastas apontaram para questôes tais como a aproximação dos canais de televisão da produção de curta-metragem nacional, gerando um impulso para a produção de novos filmes, devido ao aumento da possibilidade de exibição; houve o chamamento para a importância da criação de uma entidade que representasse os produtores e diretores curtametragistas em âmbito nacional. Além disso, resolveu-se pressionar o governo federal através do INC para aperfeiçoamento da legislação de proteção ao curta-metragem e também o governo da Bahia, para que a lei estadual n²797, de 27 de maio de 1970, entre em vigor, auxiliando na produção de curtas na Bahia.

\footnotetext{
${ }^{13}$ Jornada Baiana de Curta-Metragem. Programa. 1972. Biblioteca Paulo Emílio Sales Gomes- Cinemateca Brasileira. Pasta F151(81) Salvador. Entretanto, outras fontes nos apontam, ao invés de oito filmes concorrentes, sete ou até mesmo seis. (Cf. "Sete curtas disputam quatro prêmios". Tribuna da Bahia, Salvador, v. 3, n. 668, p.1, 8 jan. 1972. Caderno 2). Biblioteca Central do Estado da Bahia Setor Hemeroteca. Maço Tribuna da Bahia Janeiro de 1972.

14 "Sete curtas disputam quatro prêmios". Tribuna da Bahia, Salvador, v. 3, n. 668, p. 1, 8 jan. 1972. Caderno 2. Biblioteca Central do Estado da Bahia. Setor Hemeroteca. Maço Tribuna da Bahia Janeiro de 1972.

${ }^{15}$ JORNADA BAIANA DE CURTA-METRAGEM. Resoluçôes do simpósio da I JBCM. Salvador, 16 de janeiro de 1972. Setor de Cinema da Faculdade de Comunicação da Universidade Federal da Bahia. Caixa Jornada 1972
} 
Há também críticas para os exibidores, que se recusam a exibir curtas, e continuavam a exibir "jornais de tela" (cinejornais), considerados pelos participantes do Simpósio como obsoletos e diminuidores das oportunidades de visibilidade para os curtas. Parabenizam a UFBA pelo apoio à atividade, e ressaltaram a importância do estímulo ao Curso de Cinema do GEC, que necessitava de equipamentos em Super-8 para a produção de filmes dos alunos. Enfim, a I Jornada Baiana de Curta-Metragem foi considerada bem sucedida no seu principal propósito que consistia em estimular a atividade cinematográfica, não só na Bahia, mas trazendo cineastas de outros estados também.

\section{Jornada Nordestina de Curta-Metragem (09 a 13 de setembro de 1973)}

A II Jornada foi preparada de modo a aprofundar e ampliar as discussões colocadas no ano anterior. Isto significou reiterar a identidade das Jornadas enquanto um espaço de trabalho, através da "ausência total do mundanismo tradicional dos festivais, abertura para todas as experiências cinematográficas e um acentuado clima de trabalho". ${ }^{16} \mathrm{O}$ "mundanismo" seria o clima de "pouca seriedade" dos festivais de, aos quais os artistas e realizadores frequentam com o intuito de alavancar suas carreiras através da exposição no que o hoje compreendemos como mídia. Esta alfinetada da organização através do programa da II Jornada provavelmente objetivou demarcar a diferença entre as atividades desenvolvidas na Jornada, com um caráter de debate e construção de propostas em relação aos problemas do cinema baiano, que eram em grande medida os mesmos do conjunto do cinema brasileiro.

A II Jornada sai do mês de janeiro, para setembro, permitindo assim, que o evento possa se realizar com mais tranquilidade do que durante o mês de janeiro, que é um mês de férias e "festas de largo" em Salvador. ${ }^{17}$ Esta preocupação com o período da jornada fazia sentido, porque neste ano ela aumenta de tamanho e ambiçôes. De um evento cinematográfico baiano, (mesmo registrando a presença de participantes de outros estados) com poucos filmes em concurso, passou-se a uma atividade de temática nordestina, mas de amplitude nacional, com mostras competitivas não só de super-8 e $16 \mathrm{~mm}$, como também de $35 \mathrm{~mm}^{18}$ - significando um envolvimento maior

\footnotetext{
${ }^{16}$ JORNADA NORDESTINA DE CURTA-METRAGEM. Programa. Salvador: ABC Gráfica Offset, 1973. p. 1.

${ }^{17}$ Cf. Guido Araújo (1972).

18 JORNADA NORDESTINA DE CURTA-METRAGEM, 2., Salvador. Regulamento. Setor de Cinema da Faculdade de Comunicação da Universidade Federal da Bahia. Caixa Jornada 1973.
} 
de cineastas profissionais - o que legitimava a Jornada nacionalmente enquanto um espaço de aglutinação de pessoas interessadas em discutir, propor e implementar medidas de fortalecimento do cinema brasileiro, especialmente de curta-metragem.

Entendemos que a Jornada configurou-se enquanto um fórum privilegiado de discussão sobre o cinema brasileiro, em virtude do momento de repressão sofrido pelas atividades culturais devido à ditadura militar, especialmente após o AI-5. Como grande parte das suas atividades eram realizadas no Instituto Goethe, também conhecido como Instituto Cultural Brasil-Alemanha (ICBA), que era equivocadamente considerado possuidor de imunidade diplomática, era possível que os debates e exibições fossem realizados num clima de relativa liberdade, visto que ocasionalmente existiam censores "à paisana" assistido as atividades ${ }^{19}$. Entretanto, a entrada ostensiva da repressão só poderia ser efetuada com autorização da direção do instituto.

A importância das discussões se materializava através do "Simpósio sobre o Mercado do Filme de Curta-Metragem”, que neste ano gerou resoluçōes que foram consideradas de grande importância para o posicionamento e organização das pessoas envolvidas com as atividades cinematográficas, tais como a fundação da Associação Brasileira de Documentaristas (ABD), a rearticulação do movimento cineclubista, a proposta de formação de um mercado paralelo para a exibição de curtas-metragens e o estímulo a produção em super-8.

O Simpósio desenvolveu-se a partir de três temáticas: mercado paralelo, a estruturação nacional do movimento cineclubista e o filme super-8. No desenrolar dos trabalhos, foram instituídas três comissões que ao final divulgaram documentos relativos às suas discussões, com sugestôes e indicações. Dentre elas, sugeriu-se a criação de um mercado paralelo de articulação nacional, responsável pela exibição de filmes brasileiros produzidos na bitola de $16 \mathrm{~mm}$, envolvendo os cineclubes e cinemas de arte. Para isto, a reestruturação do movimento cineclubista, que havia sido desarticulado pela ditadura se fazia necessária, pois eles seriam os principais canais de difusão, tentando assim resolver o descompasso entre produção e distribuição ${ }^{20}$.

A comissão responsável por discutir a bitola super-8, reiterou a necessidade de uma melhora técnica na realização dos filmes, para que as experimentaçôes estéticas e de linguagem possam ser realizadas de modo atraente para o

\footnotetext{
${ }^{19}$ Entrevista concedida por Luiz Orlando da Silva em 27 de abril de 2005. Luis Orlando participou da organização e produção das Jornadas desde 1977. Foi também um militante de atuação e reconhecimento nacional no movimento cineclubista.

20 "A contribuição da Jornada". Tribuna da Bahia, Salvador, p. 11, 12 set. 1973.
} 
público assistente. Houve também sugestôes a respeito das possibilidades de divulgação do cinema para além das salas tradicionais, o que seria mais viável com esta bitola, pois não tem inserção no mercado exibidor ${ }^{21}$. Por fim, a comissão responsável pela legislação do curta-metragem gerou a $\mathrm{ABD}$, que seria a instituição responsável por congregar e defender os interesses dos profissionais ligados a produção de documentários, curtas e médias-metragens, "servirá como centro polarizador de energia criadora de um dos mais importantes setores da cinematografia brasileira, e atuará sempre em nome e a favor e um cinema como veículo cultural". (TAVARES, 1978, p. 19)

A sede organizacional da associação seria no Rio de Janeiro, devido à necessidade da aproximação dos centros de influência, que em termos culturais estavam no sudeste.

Estavam também inseridas na programação da II Jornada, as mostras informativas, que foram cinco. A "Seleção dos Premiados do Festival Nacional do Curta-Metragem - 73"; a "Mostra do Filme Amazonense"; a "Mostra Oberhausen 71-73" que exibiu os quarenta filmes premiados no festival. A "Retrospectiva Thomaz Farkas", que objetivou homenagear, através da exibição dos seus filmes, um dos principais cineastas e fotógrafos do cinema brasileiro, produtor da chamada Caravana Farkas, que documentou o interior do nordeste brasileiro entre as 1964-69, contribuindo com a renovação na linguagem e estética do documentário brasileiro. ${ }^{22}$ Houve também a "Mostra Informativa Nacional Super-8", um panorama da produção em super-8 brasileira, e que foi organizada de modo a fazer interface com o "Seminário Super8 ", ministrado por Jorge Bodansky, cineasta paulista com experiência em curtas e longas-metragens, composto por aulas teóricas e práticas, que buscavam exercitar o uso do super-8 de um modo similar ao das outras bitolas, no sentido da busca por um padrão de qualidade estética e técnica. Nesta Jornada, a participação superoitista começou a ser sentida de modo numericamente expressivo, pois se na Baiana não houve nenhuma inscrição, na Nordestina, entre 30 filmes inscritos nas Mostras Competitivas - que se organizavam por bitola - 11, eram em Super-8. Sete pernambucanos, dois paraibanos e três baianos. A desejada aproximação da juventude baiana, ainda não havia ocorrido a contento, pois nas bitolas de 16 e $35 \mathrm{~mm}$, onde as produçóes baianas eram maioria, os realizadores eram em grande parte aqueles que venceram na I Jornada ou já tinham aproximação com a atividade cinematográfica antes das

\footnotetext{
21 "Super-8: resultado depende de quem usa". Jornal da Bahia, Salvador, p. 2, 4 set. 1973.

${ }^{22}$ Para aprofundamento nas discussões relativas à produção de Thomaz Farkas. (Cf. LUCAS, 2006; RAMOS, 2007)
} 
Jornadas, mas que de todo modo, ajudaram com a sua participação a demarcar um espaço importante para o curta-metragem no panorama nacional.

\section{Jornada Brasileira de Curta-Metragem (09 a 14 de setembro de 1974)}

Em termos organizacionais, a III Jornada trouxe poucas transformações. Houve a mudança de nordestina para brasileira, atualizando o nome do evento com a realidade vivenciada, pois desde a jornada anterior, a abrangência do evento era nacional. Nesse sentido, a finalidade é ampliada em três tópicos, através da temática "o homem no seu meio ambiente"23. $\mathrm{Na}$ escrita do regulamento, é possível sentir a influência das decisões tomadas no Simpósio anterior, tais como a chamada mais específica aos documentaristas e a perspectiva de cooperação entre os cineclubes e cineastas. Mantêm-se a divisão da mostra competitiva por bitolas com premiação específica, mas não mais a seleção prévia dos filmes, ou seja, todos os filmes inscritos puderam participar do concurso, desde que recebessem a aprovação da censura. ${ }^{24}$

A programação permanece com a mostra competitiva, e as mostras informativas, que foram sobre cinema documental e uma retrospectiva sobre o "Cinema Primitivo Nordestino". Além delas, ocorreu uma exposição "A História do Cinema Brasileiro através do Cartaz”. O Simpósio sobre o curtametragem passou à responsabilidade $\mathrm{da} \mathrm{ABD}$, mas continuou concentrando as temáticas relativas ao curta com suas legislações, inserção no mercado e na televisão, além da discussão relativa a métodos de documentação cinematográfica, que reuniu críticos, cineastas e pesquisadores num esforço de criação e manutenção da história do cinema brasileiro.

Esta atividade pode ser vista como uma continuidade das discussóes colocadas pela reunião preparatória para o III Encontro de Pesquisadores do Cinema Brasileiro, que aconteceu no ano anterior. Esta percepção também é possível no que diz respeito ao Encontro da Federação Norte e Nordeste de Cineclubes, visto que as reuniōes do simpósio da Jornada de 73 evidenciaram a necessidade da articulação e organização dos cineclubes para o bom funcionamento da proposta do mercado paralelo. Entretanto, uma das coi-

\footnotetext{
${ }^{23}$ Jornada Brasileira de Curta Metragem, 3. 1974, Salvador. Regulamento. Setor de Cinema da Faculdade de Comunicação da Universidade Federal da Bahia. Caixa Jornada 1974.

24 “Censura aprova os filmes da Jornada de Curta-Metragem”. A Tarde, Salvador, n. 20.703, p. 3, 18 set. 1974 . Biblioteca Central do Estado da Bahia Setor Hemeroteca. Maço A Tarde, Salvador, set. 1974; Sobre a relação da Jornada com a censura há também os registros das entrevistas com Guido Araújo, Nélia Belchote e Luiz Orlando da Silva.
} 
sas que considero mais importantes nessa jornada foi o tom crítico que permeou as atividades, e que foi possível sentir nos documentos ${ }^{25}$ gerados pelos simpósios e também pelas declarações dadas pelos cineastas participantes do certame à imprensa ${ }^{26}$. Estes documentos e declarações evidenciam a percepção de que não bastam os festivais e fórum de debates, é preciso que as ações realmente se efetivem durante o ano corrente, algo que não estava ocorrendo, provavelmente por falta de uma articulação mais duradoura entre os membros dos Simpósios e das entidades eu se relacionam com a atividade cinematográfica.

Devemos também pontuar o crescimento no interior da Jornada, do discurso que punha o cinema como um intérprete privilegiado da "realidade brasileira" e por isso, um produto cultural que mereceria mais atenção e respeito por parte dos órgãos governamentais e mais organização por parte dos cineastas - o que enfatiza a importância da $\mathrm{ABD}$ enquanto elemento de pressão. As queixas relativas ao tipo de tratamento dispensado pelo INC ao cinema de curta-metragem permaneceram, mas alguns cineastas foram esperançosos no que diz respeito à fusão entre o INC e a Embrafilme. ${ }^{27}$

Há nesta Jornada uma polêmica envolvendo o filme Comunidade do Maciel - há uma gota de sangue em cada poema, documentário em $16 \mathrm{~mm}$, de Tuna Espinheira e a censura. Segundo o diretor, o filme teria sido censurado a pedido da própria entidade que o encomendou por discordar da sua abordagem sobre o Pelourinho. Houve uma acalorada discussão acompanhada por alguns órgãos de imprensa, na qual o Instituto do Patrimônio Artístico Cultural da Bahia (IPAC) se exime da responsabilidade. No entanto, o filme foi exibido e premiado no Festival de Curitiba do mesmo ano. Este episódio coaduna a ideia de Inimá Simões (1999) de que cinema de curta-metragem fazia um serviço de contra-informação. Para ele, o tamanho compacto dos equipamentos e a relativa facilidade de trânsito desses filmes, através de festivais, cineclubes, associações de bairro e classe,

\footnotetext{
25 "A ABD e a problemática do curta-metragem"; "Métodos de documentação e análise cinematográfica"; "Mercado da TV para o curta"; "Encontro de Cineclubes Norte/ Nordeste" e "Definiçōes do Mercado Paralelo". Documentos transcritos em Tavares (1978, p. 27-39); Ata de reuniāo do grupo de trabalho sobre a problemática do curta-metragem brasileira. Setor de Cinema da Faculdade de Comunicação da Universidade Federal da Bahia. Caixa Jornada 1974.

26 "Recuperação de cineclubes pode significar abertura de mercado“. Tribuna da Bahia, Salvador, v. 5, n. 1514, p. 11, 16 set. 1974. Biblioteca Central do Estado da Bahia Setor Hemeroteca. Maço Tribuna da Bahia Setembro de 1974; “Documentário ou reportagem superficial?" Tribuna da Bahia, Salvador, v. 5, n. 1514, p. 11, 16 set. 1974; "Filmes de curta-metragem: muitos problemas, algumas perspectivas". Tribuna da Bahia, Salvador, v. 5, n. 1514, p. 11, 16 set. 1974; "Guido: filmes acomodados foram a tônica da Jornada”. Tribuna da Bahia, Salvador, v. 5. n. 1516, p. 5, 18 set. 1974. Biblioteca Central do Estado da Bahia Setor Hemeroteca. Maço Tribuna da Bahia Setembro de 1974.

27 Sobre a trajetória da legislação do cinema brasileiro e atuações do INC e da Embrafilme. (Cf. RAMOS, 1978).
} 
faziam circular imagens e, sobretudo abordagens que desagradavam ao estado autoritário. ${ }^{28}$

\section{Jornada Brasileira de Curta-Metragem ( $1^{\circ}$ fase: 02 a 06 de setembro e $2^{\circ}$ fase: 08 a 14 de setembro de 1975 )}

Se a III Jornada foi considerada acomodada, sem grandes transformações, na IV é possível mapear uma movimentação maior, provavelmente provocada por mudanças na organização do evento. O regulamento propôs um evento em que a produção cinematográfica seja incentivada sem diferenciação entre as bitolas e assume um direcionamento para o incentivo a produção de documentário e para a discussão relativa à descentralização da produção, o que visibilizou mais a necessidade já colocada nas outras jornadas, da parceria entre os cineastas, Embrafilme, e governos estaduais e municipais, gerando propostas diversas de ativação da produção, sob o viés da descentralização. (SETARO, 1975a, 1975b) ${ }^{29}$

Estruturalmente, a IV Jornada foi dividida em duas partes. A primeira, correspondeu a: "a) apresentação dos filmes concorrentes de curta-metragem em 35 mm, 16 mm e super 8 para a Comissão de Seleção; b) Seminário sobre a Problemática do Curta-Metragem no Brasil; c) Programação especial dos filmes premiados nos dois últimos Festivais de Oberhausen”. E a segunda:
a) Apresentação para o público dos filmes escolhidos pela Comissão de Seleção;
b) Mostra Informativa dos filmes não selecionados;
c) Debate crítico dos filmes da jornada;
d) Simpósio Nacional sobre as perspectivas da descentralização da produção cinematográfica e a abertu- ra do mercado para o $16 \mathrm{~mm}$;
e) Mostra informativa do Documentário Latino-Americano;

\footnotetext{
${ }^{28}$ É possível acompanhar o desenrolar desse fato através da cobertura da imprensa. (Cf. "Vivaldo da Costa Lima fala sobre filme "Comunidade do Maciel'”. Tribuna da Bahia, Salvador, v. 5, n. 1516, p. 5, 18 set. 1974 . Biblioteca Central do Estado da Bahia, Setor Hemeroteca. Maço Tribuna da Bahia, Setembro de 1974; "Espinheira mostra engano do diretor". Tribuna da Bahia, Salvador, v. 5, n. 1516, p. 5, 18 set. 1974; "Proibido 'Comunidade do Maciel”. A Tarde, Salvador, n. 20.703, p. 3, 18 set. 1974. Biblioteca Central do Estado da Bahia, Setor Hemeroteca. Maço A Tarde, set. 1974.

29 “Farias: convênio para a Bahia”. Tribuna da Bahia, Salvador, v. 6, n. 1812, p. 11, 15 set. 1975.
} 
f) Debate sobre o filme Latino-Americano e a possibilidade de Intercâmbio. ${ }^{30}$

Esta nova forma de organização incluiu a "interiorização" do evento, que consistiu em debates e exibiçôes dos filmes premiados das Jornadas anteriores em Feira de Santana, objetivando a difusão da cultura cinematográfica no interior do estado, e que teve como uma das principais conseqüências, a reativação do Clube de Cinema de Feira de Santana (BELCHOTE, 1975, p. 2). ${ }^{31}$ Neste formato, volta a existir a Comissão de Seleção, responsável por criar os programas das mostras competitivas, separadas por bitolas $(35 \mathrm{~mm}$, $16 \mathrm{~mm}$ e Super-8). Devido ao aumento expressivo da produção superoitista e dos festivais a ela dedicados, há uma cláusula específica, que exige o ineditismo da produção, ou seja, não ter competido em nenhum outro festival anteriormente.

A IV Jornada foi uma das quais a rivalidade entre os realizadores em 35 $\mathrm{mm}$ e super-8 mais se acirrou, pois os superoitistas consideraram-se discriminados pela organização, pois o aluguel-prêmio ${ }^{32}$ a que o regulamento se reporta foi pago aos realizadores das outras bitolas, excluindo-os, embora quase a metade dos filmes exibidos fosse em Super-8. Do seio desta polêmica, emerge uma questão - como foi visto anteriormente, a própria Jornada, através da sua abertura, no regulamento, de cursos e sucessivos debates, estimulou desde 1972 a produção superoitista, encarando-a como uma maneira de seduzir a juventude para a prática cinematográfica, estimulando a produção.

Entretanto, o perfil das Jornadas foi tornando-se paulatinamente mais profissional, preocupando-se legitimamente com questôes relativas à inserção no mercado da produção curtametragista profissional, e ao mesmo tempo, cobrando desses cineastas criatividade e força expressiva. Só que, pelo que pudemos apreender da documentação consultada, eram os superoitistas, considerados geralmente como amadores, os que mais contribuíram com filmes propositivos e com criatividade, a despeito dos flagrantes problemas técnicos. Houve, assim, uma polarização na qual os cineastas do $35 \mathrm{~mm}$ eram considerados profissionais, mas, em contrapartida, acomodados; por sua vez, os cine-

\footnotetext{
${ }^{30}$ Jornada Brasileira de Curta-Metragem, 4., 1975, Salvador. Regulamento. Setor de Cinema da Faculdade de Comunicação da Universidade Federal da Bahia. Caixa Jornada 1975.

${ }^{31}$ JORNADA BRASILEIRA DE CURTA-METRAGEM, 4. Boletim informativo, n. 4, jul. 1975. Setor de Cinema da Faculdade de Comunicação da Universidade Federal da Bahia. Pasta IV Jornada Brasileira de Curta-Metragem 1975. ( $1^{\circ}$ fase: 02 a 06 de setembro e $2^{\circ}$ fase: 08 a 14 de setembro de 1975).

${ }^{32}$ Valor pago pela organização das Jornadas pela participação do filme na mostra competitiva.
} 
astas do super-8 eram vistos como criativos, mas irresponsáveis, sem compromisso, "cineastas de curtição". ${ }^{33}$

Isso parece decorrer do fato de se atribuir a cada bitola uma suposta 'linguagem intrínseca' mecanicamente a reboque dos seus respectivos custos de produção. Ora, o cinema experimental e o cinema de curtição sempre frutificaram dentro do $35 \mathrm{~mm}$ - o próprio cinema brasileiro o atesta. E o super-8 tanto nos tem dado filmes notáveis pelo seu nível técnico e estético, quando por uma infindável série de produções achatadamente comerciais - aí estão as agências de publicidade, que dele não abrem mão.

Não existe uma correspondência mecânica, rígida, obrigatória entre a bitola empregada e a atitude que se assume. (TAVARES, 1978, p. 61, grifo do autor)

Esta análise empreendida por Tavares pode abrir a reflexão sobre as questões colocadas nos debates relativos à descentralização da produção, pois uma das suas motivações é justamente a diversificação da atividade cinematográfi$\mathrm{ca}$, que se revela tanto na multiplicidade temática, da região produtora, quanto das bitolas também. O Simpósio Nacional da ABD dividiu se em três grupos de trabalho: "Distribuição centralizada do curta-metragem", "Regulamentação do curta”, "Descentralização da produção e financiamento", que geraram mais uma vez documentos indicando proposiçōes de melhora do panorama do cinema brasileiro. Dentre essas discussões a que se mostrou mais profícua foi a da descentralização da produção, pois mexeu com o tema da estruturação do mercado produtor e exibidor nacional, que se concentrava no eixo Rio de Janeiro - São Paulo.

Uma outra problemática vivida pelos participantes foi relativa à censura. Esta foi a edição que mais sentiu a intromissão dos censores. Dos 72 filmes inscritos, quatro tiveram sua exibição proibida e dois só seriam liberados mediante aos cortes indicados pelos censores. ${ }^{34}$ A discussão relativa a censura

\footnotetext{
33 "Cineastas do super-8 descontentes com a discriminação da Jornada". Tribuna da Bahia, Salvador, v. 6, n. 1812, p. 11, 15 set. 1975; "Cineastas preferem fazer turismo a debater filmes na Jornada". Tribuna da Bahia Salvador, v. 6,.n. 1809, p. 14, 11 set. 1975.

${ }^{34}$ Os filmes interditados foram: "Restos" de João Batista De Andrade, "Veias Abertas", de Luiz Arnaldo Dias Campos, "Tarumâ", de Aloysio Raulino e "A Conversa", de Paulo Roberto Ribeiro, Francisco Maia, José Alberto e Pedro Braga Souto Maior. Os que tiveram sugeridos os cortes foram: Pedro Piedra" de Francisco Liberato, que mesmo assim recebeu o prêmio Alexandre Robatto Filho e "Tomadas no Lixo" de Albert Hemsi e Giselle Gubernikoff sendo que seus autores retiraram o filme, por não concordarem com os cortes.
} 
mobilizou os cineastas que lançaram um documento repudiando a ação. Neste, a ação da censura é compreendida como uma tentativa de controle que tem como consequência direta o enfraquecimento do cinema nacional, por não permitir o seu desenvolvimento temático pleno. ${ }^{35}$

\section{Jornada Brasileira de Curta-Metragem (08 a17 de setembro de 1976)}

Devido à insatisfação e ao protesto dos cineastas superoitistas, a $V$ Jornada muda mais uma vez o seu formato, objetivando torná-lo mais igualitário entre as bitolas. Para isto, eliminou-se a distinção entre elas tanto no momento da exibição quanto da premiação. Até a IV Jornada, os filmes eram premiados de acordo com a bitola, nesta, os laureados foram escolhidos por gênero: documentário, ficção e animação, sendo o último prêmio transformado em "prêmio especial". A programação foi montada mesclando bitolas e gêneros e todos os filmes inscritos tiveram direito a participar distribuição equitativa da verba encaminhada pela Embrafilme e a concorrer aos prêmios distribuídos pelas entidades parceiras da V Jornada.

O formato do Simpósio Nacional da ABD não foi alterado - os participantes dividiram-se em duas comissões responsáveis por elaborar projetos para "Regulamentação do mercado comercial" e "Regulamentação do mercado alternativo (cineclubes e TV)”. A preocupação com a inserção do curta-metragem no mercado cinematográfico brasileiro sempre foi uma constante nas discussões dos Simpósios, mas neste ano ela foi reforçada pelas modificações no cenário causadas desde o ano anterior devido a lei de obrigatoriedade de exibição de um curta brasileiro antes de um longa estrangeiro e pela extinção do INC e conseqüente ampliação das funções da Embrafilme que a partir de então iria "financiar, co-produzir e distribuir filmes brasileiros e também [...] preservar a 'memória nacional'”. (RAMOS, 1983, p. 133)

Entretanto, era necessário atentar para as especificidades do filme curtametragem, sendo por isso essencial, segundo os participantes da comissão, um planejamento cuidadoso para evitar que possíveis distorções e brechas na lei prejudicassem ao invés de proteger o curta. ${ }^{36}$ Por sua vez, a comissão de "mercado alternativo e produção" ressaltou a importância do movimento cineclubista

\footnotetext{
${ }^{35} \mathrm{O}$ documento está transcrito em Tavares (1978, p. 56).

${ }^{36}$ JORNADA BRASILEIRA DE CURTA-METRAGEM, 5. Relatório da Comissão de Regulamentação do Mercado Comercial de Curta-Metragem. Set. 1976. Setor de Cinema da Faculdade de Comunicação da Universidade Federal da Bahia. Caixa V Jornada Brasileira de Curta-Metragem 1976.
} 
para o funcionamento do "mercado alternativo" 37 , que aparenta ser uma atualização do debate relativo ao "mercado paralelo".

A proposta lançada por este grupo de trabalho incluiu o apoio a então recente fundação da Distribuidora Nacional de Filmes para Cineclubes (DINAFILME), distribuidora responsável pelos filmes que faziam parte deste mercado não convencional. Através do documento ${ }^{38}$, percebe-se que a discussão sobre a descentralização da produção ainda estava presente, pois sem a diversificação dos filmes, não haveria o que distribuir. Para a efetivação da difusão desta produção descentralizada, os cineastas recomendaram a construção de centros regionais de produção em parceria com os governos municipais e estaduais, além da própria Embrafilme. Em relação ao mercado do cinema na televisão, a $\mathrm{ABD}$ propôs a partir da utilização de uma verba recentemente liberada pelo Ministério da Educação (MEC), que 50\% dessa quantia seja empregada na compra dos direitos de exibição para a televisão da produção nacional tanto em curtas quanto em longas-metragens, que têm sido constantemente rechaçadas pelos canais de televisão. ${ }^{39}$

A polêmica desta edição foi por conta da existência da Comissão de Seleção que teve sua legitimidade questionada nos debates que ocorreram no final da exibição de cada sessão, a partir da retirada do filme Gaiolas pelo seu próprio diretor, Carlos Frederico, da mostra competitiva, por discordar dos critérios da comissão. Assim, foi inserido na programação o Fórum Administrativo, nos quais os participantes (cineastas, produtores, público) poderiam sugerir modificações futuras, tais como a de que a VI Jornada não contaria mais com seleção e nem premiação oficial.

\section{Jornada Brasileira de Curta-Metragem (8 a 15 de setembro de 1977)}

A VI Jornada procurou atender as reivindicações e sugestões colocadas pelos participantes no Fórum Administrativo da Jornada anterior, que consistiu em suprimir tanto a premiação oficial, quanto a seleção prévia dos filmes. Os cineastas poderiam inscrever mais de um filme, indicando qual faria parte da mostra competitiva, pois somente os filmes concorrentes teriam direito a participar do rateio do aluguel prêmio, sobre o qual foi decidido no fim da

\footnotetext{
37 "Mercado alternativo é todo aquele fora do circuito comercial, atendido por qualquer forma de distribuição organizada, que possa remunerar o mais equitativamente possível os realizadores de filme”. (Cf. TAVARES, 1978, p. 69)

${ }^{38}$ A DINAFILME foi fundada na X Jornada de Cineclubes, em Juiz de Fora, em fevereiro de 1976. Cf. Macedo (2008).

39 "V Jornada acaba e quer regulamentar mercado de filmes“. A Tarde, Salvador. n 21.312, p. 2, 17 set. 1976.
} 
Jornada que os superoitistas receberiam a metade do valor destinado aos realizadores em 35 e $16 \mathrm{~mm}$.

$\mathrm{O}$ atendimento das reivindicações dos cineastas acarretou numa mostra competitiva considerada cansativa, pois os programas ficaram longos devido a quantidade de filmes, que foram estipulados em 77, distribuídos em 10 programas, seguidos dos debates, além das mostras paralelas, informativas e programação especial que somadas com a oficial, resultou em cerca de 120 filmes no total da Jornada.

No tocante a mostra oficial, houve polêmica nos debates e na cobertura da imprensa sobre o desnível técnico dos filmes participantes. Filmes profissionais, bem realizados, ladeados com outros considerados amadores e com problemas na estrutura narrativa e mesmo de uso do equipamento. Nas entrelinhas dessa contenda ainda permaneciam as problemáticas e hostilidades entre os realizadores do $35 \mathrm{~mm}$ e os do Super-8.

Contudo, há também nesse debate um dos dilemas que perpassam a produção curtametragista que é tentar se equilibrar na difícil equação entre absorção do filme pelo mercado exibidor e o exercício da liberdade criativa do cineasta. $\mathrm{Na}$ verdade, esse não seria o dilema somente do cinema de curtametragem, mas em certa medida de grande parte do cinema brasileiro, que na década de 1970 passa por paulatinas transformações estéticas, conteúdo e de linguagem, visto que os modelos interpretativos da década anterior não se mostravam satisfatórios (JORGE, 2003; RAMOS, 1983).

Jean-Claude Bernardet (1985) fez uma análise sobre essas modificações, centrando sua atenção no documentário de curta-metragem, selecionando filmes que trouxeram contribuições na superação do que ele caracteriza como "modelo sociológico" (que seria construído através da necessidade de politização das artes através das preocupaçóes com a problemática social. A linguagem cinematográfica buscava se legitimar através do uma abordagem cientifizante), mas que continuavam sem uma preocupação primordial com a inserção no mercado, reafirmando o curta-metragem como espaço de criatividade, liberdade e experimentação. Alguns dos filmes analisados por ele, como Os queixadas, Acidente de Trabalho e Migrantes foram premiados nas Jornadas e isto nos ajuda a apreender a complexidade do debate a respeito da qualidade e criatividade das produções, pois estes são filmes de realizadores considerados profissionais, e que têm o sopro criativo que nas discussōes eram atribuídos quase que exclusivamente aos superoitistas.

Esta Jornada guardou um momento importante na trajetória do cinema brasileiro, no tocante aos debates relativos a "Lei do Curta", implementada a 
partir da Resolução $n^{\circ} 18$ do Concine, que tornou obrigatória a exibição de curtas-metragens brasileiros antes de cada filme estrangeiro. Mesmo sendo um passo considerável para a ocupação do mercado brasileiro por produções brasileiras, houve pontos de insatisfação e discordâncias, que foram debatidos pelos realizadores, com o presidente do Concine, Alcino Teixeira Neto, no Simpósio Nacional da $\mathrm{ABD}$, gerando com isso documentos importantes, que direcionaram a atuação dos cineastas enquanto categoria, para reivindicação em face ao governo e as distribuidoras e exibidoras. ${ }^{40}$

É também nessa Jornada que começa a ser rodado o Jornal da Jornada, jornal que se reivindicava independente da direção da Jornada e que trazia diversos textos, entrevistas e opiniōes a respeito dos acontecimentos da Jornada e do cinema brasileiro. Apresentava debates polêmicos, como a inserção feminina no mercado de trabalho cinematográfico, a existência e necessidade do mercado paralelo e, sobretudo, a dependência do cinema brasileiro às subvenções do governo.

É interessante pontuar que foi apenas na documentação relativa a esta Jornada que encontrei material gerado pela própria organização tentando construir um perfil dos participantes, que eram aproximadamente 450, com sessões em que se estimavam 200 pessoas, divididas percentualmente (creio que também de modo aproximado) em 50\% de estudantes universitários, 20\% de estudantes de nível médio e 30\% de público comunitário, categoria que não está bem explicitada, mas que provavelmente diz respeito aos participantes que não se enquadravam nas denominações anteriores. ${ }^{41}$

Estas informações assemelham-se as que pude obter através da entrevista com Luiz Orlando da Silva, que evidencia grande presença estudantil, especialmente universitária. A fala pode complementar estes dados porque ela traz uma avaliação qualitativa, que nos ajuda a delinear melhor quem eram essas pessoas, oriundas das esquerdas intelectualizadas, do movimento estudantil e os ativistas das mobilizações culturais fora do "circuito oficial da televisão, tanto de Salvador, quanto do interior do estado. ${ }^{42}$

\footnotetext{
${ }^{40}$ Para maiores informaçôes ver: Documento elaborado pela ABD sobra a regulamentação de exibiçāo do filme brasileiro de curta-metragem (Resoluçăo $n^{\circ} 18$ do Concine, que regulamenta a lei no 6281). Setor de Cinema da Faculdade de Comunicação da Universidade Federal da Bahia. Caixa VI Jornada Brasileira de Curta-Metragem 1977; Fala de Alcino Teixeira Neto na VI Jornada Brasileira de Curta-Metragem. Setor de Cinema da Faculdade de Comunicação da Universidade Federal da Bahia. Caixa VI Jornada Brasileira de Curta-Metragem 1977; Jornada Brasileira de Curta-Metragem, 6., 1977. Relatório. Setor de Cinema da Faculdade de Comunicação da Universidade Federal da Bahia. Caixa VI Jornada Brasileira de Curta-Metragem 1977.

${ }^{41}$ Jornada Brasileira de Curta-Metragem, 6., 1977. Relatório. Setor de Cinema da Faculdade de Comunicação da Universidade Federal da Bahia. Caixa VI Jornada Brasileira de Curta-Metragem 1977.

${ }^{42}$ Luis Orlando Op cit.
} 


\section{Jornada Brasileira de Curta-Metragem (8 a 15 de setembro de 1978)}

A última Jornada do nosso recorte começou sob o signo da polêmica, oriunda da retirada do apoio da UFBA para a realização da Jornada. O então reitor, Augusto Mascarenhas, alegou motivos financeiros para o afastamento da universidade do evento. Entretanto, o argumento não foi considerado suficientemente convincente, e a interrupção do apoio ocasionou uma repercussão nacional, articulada pelos cineastas participantes e organizadores do "acontecimento cinematográfico de setembro". (SETARO, 1978b) (33 $^{43}$

A contra-argumentação que rechaça a decisão da reitoria é proveniente basicamente das colunas de cinema dos jornais, e se constroem discutindo a concepção de universidade da UFBA, criticando o crescente descaso da instituição com os cursos relacionados com as artes, como a Escola de Teatro, e insistindo que além de ser um centro formador de profissionais de nível superior, a universidade tem um compromisso com a difusão da cultura, o que torna, nessa linha de raciocínio, ininteligível a decisão do reitor, especialmente porque a Jornada, segundo os seus organizadores já era independente financeiramente da universidade, e, sobretudo, porque era naquele momento, o principal evento cultural com a chancela da instituição.

Contudo, a despeito deste problema, a VII Jornada manteve suas atividades, mas com algumas restrições, como, por exemplo, a impossibilidade do uso espaço da Reitoria para abertura e premiação. Houve algumas alterações no formato, especialmente no que diz respeito às premiações, que demonstrou ser nessas sete Jornadas um dos pontos mais sensíveis na relação entre os cineastas e a organização. Neste ano, a organização pediu as instituições apoiadoras que habitualmente contribuíam com premiaçôes paralelas, que neste ano, direcionassem as verbas para um fundo comum de premiação, objetivando o pagamento de um aluguel-prêmio aos filmes participantes da mostra oficial, permanecendo o valor diferenciado para a bitola Super-8. Assim, existiram na VII Jornada dois prêmios oficiais - o melhor filme escolhido pela comissão julgadora e o melhor filme escolhido pelo público.

Segundo a organização, as modificações ensejam a diminuição do caráter competitivo da Jornada, para que os realizadores participantes não perdessem de vista a finalidade de

\footnotetext{
43 “ $7^{\circ}$ Jornada Brasileira de Curta-Metragem - Universidade da Bahia retira patrocínio“. Jornal do Brasil, Rio de Janeiro, 2 ago. 1978. Setor de Cinema da Faculdade de Comunicação da Universidade Federal da Bahia. Caixa VII Jornada Brasileira de Curta-Metragem 1978. Pasta de recortes; "UFBA não patrocina a Jornada e alega 'razóes financeiras". Jornal da Bahia, Salvador, 2 ago. 1978. Setor de Cinema da Faculdade de Comunicação da Universidade Federal da Bahia. Caixa VII Jornada Brasileira de Curta-Metragem 1978. Pasta de recortes. Ver também: (SETARO, 1978a).
} 
promover e estimular a produção independente do filme curto nacional, sem distinção de bitola, incentivar a discussão sobre os temas e tendências do cinema brasileiro de curta-metragem, fortalecer e ampliar as conquistas das Resoluções no 18 e 19 do CONCINE. ${ }^{44}$

Para que esses objetivos (que foram aprimorados e aprofundados na trajetória da qual tentamos dar conta) fossem alcançados, os Simpósios e reuniōes de associações de classe (Associação Brasileira de Documentaristas "ABD, Associação Brasileira de Cineastas e Federaçôes regionais de cineclubes” ABRACI) eram os espaços nos quais as atividades estreitamente relacionadas com a política cinematográfica aconteciam.

Assim, a primeira atividade da VII Jornada foi o Simpósio da ABD, que teve como principal objetivo avaliar os primeiros meses de efetiva aplicação da lei de obrigatoriedade de exibição do curta-metragem e inserida, nessa discussão, a problemática da qualidade dos filmes produzidos, pois na compreensão dos cineastas, é necessário aproveitar o espaço que a lei proporciona para conquistar o público brasileiro com bons filmes brasileiros.

Além deste simpósio, houve também o Encontro dos Dirigentes das Associações Cinematográficas e a Conferência de Imprensa e grupos de trabalho sobre a relação entre Cinema e Televisão, da qual saiu uma lista de sugestôes para a Lei de Telecomunicações. ${ }^{45}$ A programação deste ano inseriu também Mostras Informativas do cinema latino-americano, do cinema africano lusófono e uma mostra em vídeo-tape, além de uma Mostra Especial de cinema documentário, uma retrospectiva que teve como temática os filmes que obtiveram destaque nas jornadas anteriores e a exposição e o lançamento do livro sobre a trajetória das Jornadas e sua relação com o curta-metragem brasileiro.

Foi acrescido ao título da VII Jornada o nome de Paulo Emílio Salles Gomes, homenageando o professor e crítico de cinema que faleceu no transcurso da VI Jornada, e que foi um dos principais incentivadores e pesquisadores do cinema brasileiro, sendo por isso muito influente entre os realizadores e pesquisadores de cinema. Houve também uma homenagem a Olney São Paulo, cineasta baiano, também falecido. Para homenageá-lo, realizou-se uma mostra da sua obra fílmica.

\footnotetext{
${ }^{44}$ Regulamento da VII Jornada Brasileira de Curta-Metragem - Paulo Emílio Salles Gomes. Setor de Cinema da Faculdade de Comunicação da Universidade Federal da Bahia. Caixa VII Jornada Brasileira de Curta-Metragem 1978

${ }^{45}$ JORNADA BRASILEIRA DE CURTA-METRAGEM, 7., Boletim informativo, n. 13, 14 set. 1978. Setor de Cinema da Faculdade de Comunicação da Universidade Federal da Bahia. Caixa VII Jornada Brasileira de CurtaMetragem 1978
} 
A programação incluiu ainda sessões nos bairros da cidade de Salvador, como, por exemplo, a programação infantil que foi exibida no Parque da Cidade. Essas exibições que ampliaram o espaço da Jornada ambicionavam preparar a população para a implementação da "lei do curta" na cidade.

Como foi visto anteriormente, a retirada do apoio da UFBA fez com que a maior parte das atividades fosse realizada no ICBA, e o encerramento da Jornada daquele ano foi no Cinerante, um espaço ao ar livre, no pátio do Instituto, onde se localizava o Café e no qual havia espaço para a exibição de filmes. No momento seguinte, a premiação, foi exibido o longa " 25 ”, de José Celso Martinez e Celso Lucas, sobre a independência de Moçambique.

Sobre esse momento, obtivemos dois relatos igualmente interessantes embora sob angulações que destacam questões diferentes. Guido Araújo, fala desta exibição como um dos momentos mais memoráveis das Jornadas, porque estava cheio, e as pessoas estavam ansiosas e curiosas por ver o filme, participando ativamente dos debates. Luiz Orlando, fala mais do aspecto da censura, quando nos relatou que foi ele quem escreveu a ficha que foi enviada para a censura, e burlando as determinaçôes desta, disse apenas que o filme tratava de uma festa e o filme foi liberado. Ocorre que no dia da exibição, um censor estava presente, e ao assistir o filme, ficou chocado com o que viu, e quando foi pedir satisfações a respeito do filme, este já havia desaparecido. ${ }^{46}$

Estes relatos nos ajudam a sentir com mais proximidade qual era o clima da Jornada, ainda que mesclada por fortes componentes afetivos. Através deles é possível apreender que as exibições das Jornadas tinham uma participação que poderia encher um espaço onde cabiam 200 pessoas, o que é significativo para um evento que se reivindica cultural em Salvador, na década de 70, e ainda sob a ditadura militar. E pode indicar caminhos para compreendermos um pouco mais da atuação da censura e das estratégias de burla adotadas que possibilitavam a chegada e exibição de filmes que em outros espaços não eram exibidos.

${ }^{46}$ Cf. Guido Araújo (1972); Luis Orlando Op cit 


\section{REFERÊNCIAS}

AMADO, Janaína; FERREIRA, Marieta de M. (Org.). Usos e abusos da história oral. Rio de Janeiro: Fundação Getúlio Vargas, 1996.

ANDRADE, Paulo Bonavides Paes de. (Org.). História constitucional do Brasil. 3. ed. Rio de Janeiro: Paz e Terra, 1991, p. 788-791.

ARAÚJO, Guido. Jornada em tempo presente. Tribuna da Bahia, Salvador, p. 13, 12 jan. 1972. Cinema. Biblioteca Central do Estado da Bahia. Setor Hemeroteca. Maço Tribuna da Bahia Janeiro de 1972.

BELCHOTE, Nélia. Simpósio inicia hoje. Jornal da Bahia, Salvador, v. 17, p. 2, 10 set. 1975. Caderno 2.

BERNARDET, Jean-Claude. Cineastas e imagens do povo. São Paulo: Brasiliense, 1985.

CARVALHO, Maria do Socorro. Imagens de um tempo em movimento: cinema e cultura na Bahia nos anos JK (1956-1961). Salvador: Edufba, 1999.

GOMES, Paulo Emílio Sales. Cinema: trajetória no subdesenvolvimento. 2. ed. Rio de Janeiro: Paz e Terra, 2002.

JORGE, Marina Soler. Industrialização cinematográfica e cinema nacional-popular no Brasil dos anos 70 e 80. História: Questóes \& Debates, Curitiba, v. 20, n. 38, p. 161-182, 2003.

LUCAS, Meize Lucena. Caravana Farkas: itinerários do documentário brasileiro. Revista Olho da História, Salvador, v. 12, n. 9, dez. 2006.

MACEDO, Felipe. Da distribuição clandestina ao grande mercado exibidor. [19-?] <http:// cineclube.utopia.com.br/historia/clandestina.html>. Acesso em: 10 ago. 2008.

RAMOS, Clara Leonel. As múltiplas vozes da Caravana Farkas e a crise do "modelo sociológico”. Dissertação (Mestrado em Ciências da Comunicação) - Escola de Comunicação e Artes, Universidade de São Paulo, 2007.

RAMOS, José Mário Ortiz. Cinema, estado e lutas culturais - anos 50, 60 e 70. São Paulo: Paz e Terra, 1983.

RAMOS, José Mário Ortiz. Cinema, estado e lutas culturais - anos 50, 60 e 70. Rio de Janeiro: Paz e Terra, 1978.

RIDENTI, Marcelo. Em busca do povo brasileiro: artistas da revolução, do CPC à era da TV. Rio de Janeiro: Record, 2000.

TAVARES, Bráulio. O curta metragem brasileiro e as Jornadas de Salvador. Salvador: Gráfica Econômico, 1978.

SALLES, Filipe. Breve história do super-8. Disponível em: <http://mnemocine.com.br>. Acesso em: 12 dez. 2007.

Princípios de cinematografia parte 2: bitolas e formatos. Disponível em: <http:// www.mnemocine.com.br>. Acesso em: 12 dez. 2007. 
SETARO, André. Ainda repercute corte descabido. Tribuna da Bahia, Salvador, 2 ago. 1978a. Setor de Cinema da Faculdade de Comunicação da Universidade Federal da Bahia. Caixa VII Jornada Brasileira de Curta-Metragem 1978. Pasta de recortes.

Por um cinema baiano participante I. Tribuna da Bahia, Salvador, v. 6, n. 1806, p. 12,8 set. 1975 a.

Por um cinema baiano participante II. Tribuna da Bahia, Salvador, v. 6, n. 1807, p. 12, 9 set. 1975 b.

. Universidade retira seu apoio a Jornada. Tribuna da Babia, Salvador, 31 jul. 1978b. Setor de Cinema da Faculdade de Comunicação da Universidade Federal da Bahia. Caixa VII Jornada Brasileira de Curta-Metragem 1978. Pasta de recortes.

SIMÕES, Inimá. Roteiro da intolerância: a censura cinematográfica no Brasil. São Paulo: SENAC, 1999.

VIEIRA, Paulo Sá. O cinema super-8 na Bahia. Salvador: Fundação Cultural do Estado da Bahia, 1984.

XAVIER, Ismail. O cinema brasileiro moderno. São Paulo: Paz e Terra, 2001. 



\section{A resposta da Bahia à} repressão militar: a ação partidária da Ala Jovem do MDB e a militância civil do Trabalho Conjunto da cidade de Salvador

Maria Victoria Espiñeira ${ }^{1}$

O Estado Burocrático Autoritário, autor de várias formas de repressão, atingiu partidos políticos, as universidades, os sindicatos e distintos grupos que eram oposição a esse regime. Ela ocorreu, principalmente, através do uso da tortura, acompanhada dos atos institucionais que comprometeram o Estado de Direito, sendo intensificada no fim dos anos 60 e início dos 70, no período denominado, no Brasil, de Anos de Chumbo. Este estudo mostra como a intensificação das perseguiçôes levou atores políticos a procurarem alternativas capazes de fazer frente a essa conjuntura repressiva, especialmente, nos meados da década de 70, quando surgem duas linhas marcantes de atuação desses grupos contra a ditadura. Uma ocorreu através da ação partidária, num quadro de bipartidarismo, quando, especialmente jovens de várias cidades brasileiras, em especial, os do Partido Comunista Brasileiro (PCB) forma-

\footnotetext{
${ }^{1}$ Profa. do Departamento de Ciência Política da Universidade Federal da Bahia (UFBA)
} 
ram a chamada Ala Jovem do Movimento Democrático Brasileiro (MDB), que era considerado o partido político de oposição. A outra linha de militância teve como participantes vários grupos constituídos por associações profissionais, artistas, políticos, estudantis egressos das guerrilhas e também de vários partidos da esquerda, igreja, representantes de bairros da periferia que formaram o "Trabalho Conjunto da Cidade do Salvador", cuja bandeira principal era: "liberdades democráticas e melhores condiçōes de vida". Essa frente, além de desenvolver açôes integradas contra a ditadura, procurou atuar nas "bases" criadas principalmente pela Igreja da linha da Teologia da Libertação, que fez opção pelo trabalho de educação política da periferia. Percebeu-se que essas açôes tiveram relevância no confronto ao regime autoritário vigente.

A partir de 1964, com a implantação do autoritarismo no Brasil, amplos setores da população passam a serem excluídos da vida política do país. O golpe militar de março permitiu ao Estado brasileiro se solidificar, fundamentando-se numa grande empresa e garantindo o processo de crescimento acelerado. Passase ao autoritarismo político assentado na Doutrina de Segurança Nacional.

Diante desse contexto alguns grupos entraram na clandestinidade e vão optar pela guerrilha, como é o caso do Partido Comunista do Brasil (PC do B), que mais tarde vai absorver um número expressivo do Grupo Ação Popular (AP). Já um outro partido que se destacava no movimento estudantil, o Partido Comunista Brasileiro (PCB), vai se voltar principalmente para alguns sindicatos e para o movimento estudantil.

Após essa fase de maior violência do Estado militar, partidos como o PC do $\mathrm{B}$ e o PCB passam a atuar numa nova conjuntura. $\mathrm{O}$ PCB tem o seu campo mais forte de atuação na política institucional, criando núcleos juvenis, onde a maioria era formada por estudantes para atuar no Movimento Democrático Brasileiro - MDB (frente criada por uma oposição "consentida" pelo regime) que possuía dentre os seus quadros "adesistas" ao próprio regime militar e um grupo denominado dos "autênticos", ou seja, que constituía uma verdadeira oposição a esse regime. A ideia de participar na vida institucional surge originalmente como uma iniciativa do PCB a partir do programa definido no seu Congresso em 1967.

No cenário baiano, foi marcante, assim, pela atuação de duas grandes forças, ou seja:

1. A Ala Jovem do MDB, que tinha uma expressiva presença eleitoral e influência na opinião pública da capital, além de ter conseguido chegar a algumas cida- 
des do interior, como está informado no seu Jornal $O$ Constituinte.

2. O Trabalho Conjunto da Cidade de Salvador, que integrava uma frente composta por diversos grupos com a hegemonia da Igreja e do PC do B (ESPIÑEIRA, 1997). Faziam parte desse grupo, principalmente, organizações de profissionais liberais, de estudantes e de bairros.

A Ala Jovem do MDB baiano foi um tipo de organização partidária juvenil que existiu em todo país nos anos 70 como um "Setor" ou "Departamento" Jovem do MDB, cuja formação estava prevista na Lei Orgânica dos partidos políticos, criada pelo regime militar. A denominação que singulariza o caso do agrupamento baiano tem a ver com uma situação ditada por circunstâncias singulares do $\mathrm{MDB}$ na Bahia.

A atuação da juventude emedebista baiana assumiu certa singularidade, política e organizacional devido, fundamentalmente, ao adesismo da Direção Regional do MDB no Estado naquele momento dominada por um agrupamento político que dava ao partido características inibidoras da constituição de uma Frente Democrática da Bahia, a qual iria se configurar de modo tardio, em relação a outros Estados brasileiros, inclusive nordestinos. Assim, a Direção Regional do Partido não reconheceu a organização da Ala Jovem, nem admitia a criação de qualquer departamento ou setor Jovem, assim como de outros departamentos estatutariamente previstos, estudantil, trabalhista, feminino, etc.

Este contexto partidário fez com que o segmento jovem baiano se distanciasse da atuação de seus congêneres nacionais por imprimir uma forma mais autônoma de ação institucional. Ao mesmo tempo, a exemplo de alguns outros estados como o do Rio Grande do Sul onde a política dos setores jovens compreendia mobilização e organização popular, procurou criar e ampliar uma base popular.

\section{O surgimento da Ala Jovem na Bahia}

A organização de um núcleo juvenil para atuar no MDB baiano surge, originalmente, como uma iniciativa do $\mathrm{PCB}$, a partir do programa definido no seu VI Congresso, em 1967. A atuação desse partido na política institucional do Estado até 1966 resumia-se, nas palavras de Sergio 
Santana $a^{2}$, "num pequeno envolvimento mais no nível da direção estadual, em apoio a candidatos" que ele avalia como "uma coisa que acontecia de uma maneira quase que de cúpula, não havia nenhum trabalho de massa envolvido nisto" 3 .

Paulo Fábio, militante do PCB na época, confirma esta estratégia, observando que desde meados dos anos 60, o "PCB e outras personalidades ligadas à esquerda, mais independentes, assumiram a posição de entrar no MDB, de apostar nessa luta eleitoral legal, no sentido de criar uma frente capaz de isolar o regime e seguir por aí, através de um processo de acumulação que fosse capaz de conquistar a liberdade democrática”.

Uma parte da esquerda de base universitária vinha assumindo nacionalmente uma posição que a levou aos variados caminhos de luta armada. Tanto grupos que optaram pela guerrilha urbana, como grupos que optaram por aquelas teorias golpistas, de buscar organização de luta revolucionária no campo se distanciavam da luta política legal por acreditar que o regime tinha cortado efetivamente todos os espaços reais de participação política e que na verdade só restava às forças realmente comprometidas com a libertação, o caminho da luta ilegal. Em outras palavras, fazer política no meio estudantil, no Brasil, até então, significava estar engajado em processos mais pesados.

Após as eleições de 1970, o quadro político na Bahia ficou ainda mais restrito devido à derrota eleitoral do $\mathrm{MDB}$ e à perda do mandato do senador Josaphat Marinho. Até então havia equilíbrio de forças, mesmo que setores mais à esquerda houvessem sido golpeados por cassaçôes de mandatos. A passagem do controle do partido para as mãos dos adesistas veio reduzir ainda mais a possibilidade de expressão política da esquerda.

Sergio Santana explica que houve, neste período, um adensamento da participação da base do PCB, ocorrendo "o primeiro trabalho de envolvimento de massa do partido com a eleição, com o processo eleitoral na campanha de Chico Pinto ${ }^{4 \prime}$, que embora mantivesse uma relação de proximidade com o PCB nunca chegou a ser membro. A eleição de Chico Pinto veio a incentivar a participação dos estudantes, permitindo a formação de uma corrente estudantil de natureza distinta da que predominava nas Universidades, cuja ten-

\footnotetext{
${ }^{2}$ Sergio Santana foi dirigente do PCB, estudante de economia e vereador a partir de março de 1975.

${ }^{3}$ Entrevista com Sergio Santana, maio 2002.

${ }^{4}$ Francisco Pinto foi, em determinado momento, uma voz mais à esquerda, embora tivesse bases eleitorais conservadoras em Feira de Santana. Produto de um contexto de desmobilização, sua ascensão deu-se pela ocupação de um espaço vazio de lideranças "orgânicas", através de um discurso vigoroso, agressivo e práticas bastante personalistas, incisivas na agitação e nas denúncias.
} 
dência era pela luta armada. Esta participação eleitoral em 1970 e para vereador em 1972, favoreceu o fortalecimento da base estudantil e reativou muitos setores de bairro do velho partido, que estavam nas sombras. $\mathrm{O}$ candidato a vereador pelo PCB, o próprio Sergio Santana, obteve uma votação expressiva, com mais de 3 mil e quinhentos votos, na sua maioria vindo dos setores médios. Como no resto do país, sobretudo no Rio Grande do Sul, começou-se a criar, com êxito, uma mobilização e uma estrutura que vinculavam a juventude ao processo eleitoral, dando origem aos setores jovens. O PCB passou a cuidar, também na Bahia, da organização de algo similar, intentando denominar esse movimento de "Juventude Democrática do MDB"

No início de 1975, o processo de articulação para a criação deste setor estava em andamento. Foi alugado um escritório, onde foram realizadas reunióes para a organização do movimento. A ideia era a de organizar um agrupamento capaz de pressionar a Direção Regional do MDB a reconhecê-lo e institucionalizá-lo.

Mas o PCB seria, de certa forma, atropelado pelos acontecimentos, pois um grupo de ativistas aliados, muitos deles próximos ou egressos do PCB, decidiu inclusive com a participação de um dirigente comunista na reunião, antecipar o lançamento público do movimento, sob outra denominação. Um ruído de comunicação fez com que o partido tomasse conhecimento do surgimento da Ala Jovem do MDB pelo jornal A Tarde, que foi o responsável, segundo Domingos Leonelli ${ }^{6}$, pela denominação adotada. Esta versão, contudo, é contestada por Sergio Santana, que atribui a paternidade do nome "Ala Jovem" a Marcelo Cordeiro, Filemon Matos $^{7}$ e ao próprio Leonelli, pessoas que "não tinham uma vinculação direta com o partido" e que, de certo modo, se anteciparam às decisões do $\mathrm{PCB}^{8}$.

Sergio Santana observa que a Ala Jovem do MDB baiano nasceu de modo informal, tendo como único documento escrito um manifesto que apresentava o desenho de um pinto saindo da casca de um ovo. Falando da Ala Jovem, afirma ele: "isso foi feito [o manifesto] na agência de publicidade de Domin-

\footnotetext{
${ }^{5}$ Entrevista com Sergio Santana, maio 2002.

${ }^{6}$ Domingos Leonelli, líder estudantil nos anos 60, Presidente da União dos Secundaristas Baianos, era ligado ao Partido Comunista Brasileiro desde essa época. Morou fora da Bahia, trabalhando como publicitário, retornando em 74. Foi candidato em emergência, no lugar de Chico Pinto, em 74, e quando Pinto foi preso,tornou-se suplente de deputado federal e com esse título ocupou um espaço na mídia como coordenador da Ala Jovem do MDB.

${ }^{7}$ Filemon Matos, economista, foi presidente da União dos Estudantes Baianos e deputado Federal pelo MDB em 1978.

${ }^{8} \mathrm{Na}$ verdade, Leonelli, Marcelo e Filemon foram, em determinada época, membros do PCB, embora na ocasião dos acontecimentos narrados, não pertencessem mais. Os dois últimos haviam sido atingidos pelo AI-5, em 1968.
} 
gos Leonelli. Teve esse manifesto que nós não participamos da redação dele, apesar de não ter nenhum documento, nós começamos a participar de algumas coisas".

Segundo o Jornal O Constituinte, editado pela Ala Jovem do $\mathrm{MDB}^{9}$, desde um seminário do MDB ocorrido em Vitória da Conquista em janeiro de 1975, um grupo de oposicionistas vinha sendo identificado como Ala Jovem, denominação que vai ser assumida no manifesto publicado por este grupo, em abril de 1975, com o título "CHEGA DE TRAIÇÃO. É HORA DE MUDAR" ${ }^{10}$. Nele é denunciado o "adesismo" baiano como o principal responsável pela derrota eleitoral nas eleições de 74 . Este documento conclama a juventude baiana a participar do MDB, pois esta "seria a forma mais concreta de isolar o adesismo e dar consequência à luta pela democracia e por melhores condições de vida para nosso povo". Esse documento, assinado pela "Ala Jovem do Movimento Democrático Brasileiro" foi, segundo o jornal, assumido por Sergio Santana, que era vereador, Marcelo Cordeiro, Adelmo Oliveira, Domingos Leonelli e Eduardo Saphira.

A estratégia do PCB era a de criar espaços institucionais de luta parlamentar legal e aumentar sua base através deste movimento jovem, que no caso baiano também constituiu numa oposição dentro do $\mathrm{MDB}$, ao grupo adesista que controla a máquina partidária. A política do $\mathrm{PCB}$ era, como já dito, e mesmo depois do lançamento público da Ala, buscar o seu reconhecimento e organização legal, dentro do estatuto do MDB, como setor jovem. Mas, tal pretensão esbarrava na posição do grupo dirigente do $\mathrm{MDB}$ regional, controlado pelo deputado Nei Ferreira ${ }^{11}$.

A informalidade foi uma marca nos três primeiros anos de existência da Ala Jovem. Conforme seus fundadores, não havia associação formal. Havia uma carta de princípios a qual as pessoas aderiam e passavam a participar. Não havia nenhuma institucionalização nem formalidade de filiação até 1978. No que concerne à luta interna no $\mathrm{MDB}$, suas ações se faziam em duas frentes, tanto organizando chapas internas para disputar convençōes contra os adesistas, como utilizando as campanhas eleitorais, tendo esta última se revelado o meio mais eficaz para isolar o grupo adversário ${ }^{12}$.

\footnotetext{
${ }^{9}$ JORNAL O CONSTITUINTE, v. 1, n. 1, set. 1977.

${ }^{10} \mathrm{O}$ jornal cometeu um equívoco. O título correto do manifesto é "Chega de Politicagem. É Hora de Mudar".

${ }^{11}$ Nei Ferreira, advogado, foi capitão de polícia, Deputado Federal, dirigente do MDB regional e genro de Antônio Balbino.

${ }^{12}$ Entrevista com Paulo Fabio, jan. 2001.
} 
O resultado das eleições de 1974 no Brasil refletiu o processo de acumulação de forças e reforçou a posição dos que defendiam o caminho da luta legal, demonstrando que esta estratégia era mais efetiva do que as que vinham sendo percorridos pelos diversos grupos que optaram pela luta armada, até porque, em 74, esses grupos estavam praticamente dizimados no país. Com a derrota militar da luta armada a alternativa institucional ganhou força.

Apesar da criação da Ala Jovem ter resultado de uma estratégia partidária do PCB e de sua liderança ser constituída de militantes ou egressos do partido, sua atuação assumiu uma direção diferente da que estava prevista pelo PCB, mais voltada para a mobilização e pressão internas, num primeiro momento. A resistência dos adesistas em permitir a criação de um setor ou departamento organizado dentro do MDB levou as jovens lideranças a criar um movimento não integrado à estrutura do $\mathrm{MDB}$, voltado para uma comunicação autônoma com a opinião pública.

A cúpula adesista do MDB da Bahia desempenhava um papel específico, visando obstruir os canais de comunicação que poderiam existir entre o partido e a sociedade, contando com uma certa apatia do comando partidário nacional e até do grupo dos autênticos. Diante desta situação, a Ala Jovem vai assumir, ao longo de sua existência, segundo Paulo Fábio, um papel inovador: "Ela passa a funcionar como uma instância de intermediação entre um movimento da sociedade civil anti-ditatorial que estava nascendo e a legenda do MDB".

A ideia de chamar este movimento de Ala, diferentemente de outros estados, onde existiam setores jovens decorre precisamente desta falta de integração orgânica com o Partido. Os próprios participantes se viam como uma ala do MDB, significando uma diferença um pouco maior do que uma simples sutileza semântica.

\section{Embate com os "adesistas" e as candidaturas da Ala Jovem}

A ação do chamado grupo adesista era voltada para manter o MDB dentro de um círculo bastante restrito, necessário exclusivamente para reproduzir alguns poucos mandatos parlamentares, o que permitiu que no interior da Bahia, principalmente, a política se polarizasse entre as facçôes diversas da Arena, passando o MDB a assumir uma mera linha auxiliar. Mesmo nos lugares onde se constituíam núcleos mais autênticos do MDB, dificilmente esses grupos chegavam a se tornar alternativas reais de poder. Havia recusa a abrir espaço para a participação dos mais diversos segmentos da sociedade, não ape- 
nas a juventude, dentro do partido, assim como para outros segmentos e lideranças políticas autênticas, com ou sem mandato. Esta restrição chegava a ponto de impedir a livre circulação dentro da sede do partido, com ameaças de violência física.

Na eleição para o controle do Diretório Municipal do MDB de Salvador, realizada em 13 de julho de 1975, o resultado foi favorável aos chamados "adesistas", que obtiveram 1.148 contra 158 da chapa chamada "Oposição Autêntica" da Ala Jovem, encabeçada pelo vereador Sergio Santana ${ }^{13}$, apesar do trabalho intenso de filiação, feito pela Ala Jovem, com vistas a assegurar um bom resultado nas Convenções.

Há apenas uma semana da realização das eleições para a renovação do Diretório, os órgãos de segurança, conforme noticiou o Jornal Opiniāo ${ }^{14}$, efetuaram a prisão de 60 pessoas em Salvador, várias delas vinculadas à Ala Jovem, inclusive o presidente da chapa oposicionista concorrente ao Diretório, vereador Sergio Santana. Na verdade, apenas uma parte dos presos tinha a ver com a Ala Jovem, pois a operação policial e paramilitar estava voltada para desmantelar toda a organização do PCB e não apenas seu esquema de atuação no MDB, como de fato ocorreu, com a prisão de todo o Comitê Estadual e do Municipal de Salvador. Apesar da amplitude da operação transcender o âmbito do MDB e estar ligada a uma ofensiva nacional do Regime contra o PCB, a data específica da operação não parece ter sido coincidência, parecendo, ao contrário, providencial. Sobre os presos pesou a acusação de

atuação anti-patriótica como elementos do Partido Comunista Brasileiro e que, segundo orientação do Movimento Comunista Internacional, procurava destruir as instituições democráticas de nossa pátria para entregá-la ao domínio de interesses alienígenos e espúrios. (nota oficial divulgada no dia 8/07/75 pelo Comando da $6^{a}$. Região Militar $)^{15}$

\footnotetext{
${ }^{13}$ Participavam da chapa para disputa do Diretório Municipal: Antonio Fernandes Pinto "vereador, Antonio Casaes" vereador, Marcelo Cordeiro, Domingos Leonelli, Leandro Amaral Lopes, Paulo Fábio Dantas Neto, Roberto Max Argolo, Geraldo Saphira Andrade, Humberto Campos Rangel, Araújo Borges, Maria Emília Coelho, Maria Consuelo Saphira Cordeiro, Miguel Kertzman, Jose de Castro Alves Oliveira, Waldemar Oliveira, João Anastácio da Silva, Manfredo Luiz G. Carvalho, Luis Carlos Barbosa, Flavio Borges Botelho Filho e o vereador Raimundo Urbano.

${ }^{14}$ Jornal Opinião, p. 2, 16 ago. 1975.

${ }^{15}$ Jornal da Bahia, 9 jul. 1975.
} 
As prisões não passaram despercebidas pela imprensa local, que comenta a receptividade favorável obtida pela Ala Jovem, junto à opinião pública, chamando a atenção para o fato de que justamente quando se faz

pela primeira vez em muitos anos no MDB um trabalho organizado visando a recuperar o controle do partido das mãos dos adesistas, alguns dos coordenadores desse trabalho, realizado pela Ala Jovem, ficam impedidos de atuar às vésperas da convenção municipal de Salvador ${ }^{16}$.

O MDB havia ganho as eleições de 74 nas grandes capitais e nas regiōes mais desenvolvidas do país. As prisóes que ocorreram em 74, 75 e 76 foram pensadas como uma forma de atacar o $\mathrm{MDB}$, vinculando-o à esquerda e, principalmente, ao PCB, preparando terreno para cassaçóes. Visava-se com isto desmontar nacionalmente a estrutura que estava sendo criada dentro do MDB. $\mathrm{O}$ motivo das prisões, portanto, não foi baiano, mas nacional ${ }^{17}$. Paulo Fábio, contudo, discorda que o alvo da operação tenha sido o MDB. Primeiro porque as prisões tiveram inicio em fevereiro de 74, quase um ano antes das eleiçôes, cuja vitória do MDB teria inspirado a repressão, e depois porque o efeito concentrou-se fundamentalmente na estrutura do PCB, inclusive com o assassinato de 10 membros do seu Comitê Central.

Passadas as primeiras duas semanas após as prisões, iniciadas a 04 de julho - quando os presos foram mantidos incomunicáveis e levados a um cativeiro clandestino, onde foram vítimas de violência física e psicológica - durante 2 meses a grande imprensa da Bahia noticiou, diariamente, o assunto. Uma grande parte dessas notícias dava cobertura ao que ocorrera - torturas, habeas corpus, visitas, apoios - e ao comportamento do grupo que controlava o MDB na Bahia. As constantes informaçõos davam contam de uma possível expulsão de Sergio Santana do MDB: "grupo adesista, liderado pelo dep. Nei Ferreira, quer que Sergio Santana seja logo expulso para dar lugar ao Sr. Degrimaldo Miranda, que pertence ao mesmo grupo adesista" ${ }^{18}$. Entretanto, conforme foi noticiado no dia seguinte no mesmo jornal "O Diretório Municipal do MDB decidiu ontem, depois de uma hora da madrugada, não expulsar Sergio Santana do Partido”. Essa mesma matéria informava que "o próprio deputado Nei ferreira fez questão de afirmar que "a decisão veio do Aeroporto", por isso a reunião, que iria iniciar

\footnotetext{
${ }^{16}$ Tribuna da Bahia, p. 2, 7 jul. 1975.

${ }^{17}$ Entrevista com Sergio Santana, maio de 2002.

${ }^{18}$ Jornal da Bahia, 11 jul. 1975.
} 
às 20 horas, somente começou às 23, quando o presidente do Conselho de Ética voltou do aeroporto depois de se encontrar com Antônio Balbino ${ }^{19}$. Quanto a esse episódio, Sergio Santana diz que:

Balbino veio do Rio para cá e no aeroporto desmontou isso [referindo-se à intenção do grupo adesista de expulsálo]. Nem me conhecia, mas disse: 'isso é um absurdo, se vocês fizerem isso vão se desmoralizar inteiramente'. Aí o diretório voltou atrás e não me expulsou.

Os apoios aos presos eram constantes, principalmente de 9 Entidades de profissionais Liberais, que eram as mais atuantes na cidade, quase todas participantes do abaixo assinado de intelectuais, personalidades como Jorge Amado, Vinicius de Morais, e a Igreja Católica, principalmente os integrantes do Mosteiro de S. Bento, tendo também o Cardeal Dom Avelar Brandão Vilela feito algumas visitas aos presos e realizado pronunciamentos.

Apesar da tentativa de desmonte do MDB, a Ala Jovem conseguiu eleger dois vereadores, em novembro de 76. Publicamente foi anunciada uma chapa de cinco candidatos merecedores da recomendação do grupo, embora apenas Marcelo Cordeiro tivesse o apoio efetivo da militância, em sua boa parte ligada ao PCB. Além de Marcelo, que obteve votação até então inédita ${ }^{20}$ foi também eleito o prof. Agenor Oliveira, que recebeu ajuda direta de Domingos Leonelli. Os outros três candidatos - Walnigno Peres, Luiz Augusto Gomes e Antonio Leite - tiveram razoáveis votaçōes" 21 .

Em 1976, pela primeira vez, não ocorreram manifestações públicas de adesismo na campanha eleitoral do MDB baiano, mas a estrutura partidária permaneceu fechada e sob controle estrito dos adesistas. A campanha de Marcelo Cordeiro desse ano foi feita nos mesmos moldes da de Domigos Leonelli e de Aristeu Almeida, dois anos antes, inteiramente por fora da estrutura do MDB e denunciando o controle que exerciam sobre a máquina partidária. Para o entrevistado, a situação só vai melhorar

\footnotetext{
${ }^{19}$ Antonio Balbino, ex-Governador e Senador do MDB, era amigo pessoal de Antonio Carlos Magalhães desde tempos anteriores a 64. Exerceu grande influência no MDB local, sendo sogro de Nei Ferreira e uma espécie de fiador deste, junto ao comando nacional do MDB, embora nem sempre concordasse com a postura de adesismo ostensivo de seu genro e liderado.

${ }^{20}$ Marcelo Cordeiro, ex-militante do PCB, ex-líder estudantil, presidente da União dos Estudantes da Bahia em 68, professor universitário e secundarista, foi eleito com quase 18 mil votos de um eleitorado concentrado nas zonas eleitoras da classe média e do meio estudantil, recorde que em 24 anos só ocorreu uma vez, na eleição de Eliana Kertész, em 1982.

${ }^{21}$ Jornal da Bahia, 11 jul. 1975.
} 
[...] lentamente, após os resultados das eleições, que foram muito desfavoráveis aos adesistas. Na realidade apenas nos meados de 77, quando Roque Aras chegou à Presidência do Partido - indicado por Nei, mas determinado a construir sua própria base independente - é que o diálogo começa efetivamente, facilitado, em grande parte também, pela atuação do Secretário-Geral do Diretório, ex-vereador Dionísio Azevedo, que atuou, em muitos aspectos, como aliado da Ala Jovem, embora permanecessem suas ligações com Nei, para uma série de outras questôes, ligadas ao interior do Estado. Ao que parece, depois de 76, Nei, sentindo que não podia mais deter um comando incontrastável sobre gente como Roque e Dionísio e também porque precisava diminuir as pressóes nacionais de Chico Pinto e outros autênticos que tentavam, fortalecidos pelas urnas, obter uma intervenção de Ulisses Guimarães no Diretório baiano, terminou afrouxando a pressão sobre a Ala Jovem. ${ }^{22}$

Em 1976, alguns outros setores da esquerda marxista, como o PC do B, o MR-8 e a AP-ML, começavam a flexibilizar sua anterior posição pelo voto nulo e, embora ainda tímida e seletivamente, aproximavam-se de políticos da esquerda do MDB. Militantes da AP e independentes chegaram a declarar voto e se acercar do Comitê de Marcelo Cordeiro sem, contudo, terem maior envolvimento com a campanha. Mas, outros setores da esquerda permaneciam no absenteísmo. Em 1978, a mesma AP e os independentes que participaram timidamente, em 76, da campanha de Marcelo, em 78, apoiaram, já entusiasticamente, Adelmo Oliveira, para estadual, e Chico Pinto, para Federal, ainda no MDB, e se integraram, depois, à Ala Jovem.

A partir de agosto de 1977, o MDB passa a ter como principal bandeira a convocação de uma Assembleia Nacional Constituinte. Nesse sentido, a preocupação da Ala Jovem se volta para o encaminhamento dessa campanha "criando círculos de debates sobre a Constituinte, nos locais de trabalho, estudo e moradia. [...] utilizará o seu jornal como veículo de debates" ${ }^{23}$.

Com a eleição em 76, Marcelo Cordeiro passou a atuar na área parlamentar e, com isso, Leonelli passa a ser a grande referência pública da Ala Jovem, durante os anos de 77 e 78, até sua própria eleição a deputado estadual em 78,

\footnotetext{
${ }^{22}$ Entrevista com Paulo Fabio, maio de 2002.

${ }^{23}$ Jornal da Bahia, 11 jul. 1975.
} 
com expressiva votação. Em 79, a experiência da Ala Jovem se esgotaria. Mas apesar do MDB ter sido extinto, Leonelli defendeu a manutenção da Ala Jovem, propondo que ela voltasse a ser o que era em 75 . Ele defendia que se

\begin{abstract}
A Ala Jovem foi criada em 75, num momento em que ela não era um órgão oficial do $\mathrm{MDB}$, conseguindo, sem ser um órgão oficial, criar um movimento de opinião importante para agregar, então ela pode repetir essa experiência agora.
\end{abstract}

Mas de 1976 até que se instalasse essa discussão, em 79, a Ala Jovem percorreu um interessante caminho de institucionalização e de tentativa de popularização, que será abordado a seguir.

Ações e relações: institucionalização, política de massa, ampliação das bases

Durante sua existência, a "Ala Jovem atraiu para o MDB centenas de jovens estudantes, trabalhadores e profissionais liberais. Até junho de 1975, mais de 1000 filiações eram encaminhadas ao MDB, fruto de mobilização e politização realizado pela Ala Jovem". ${ }^{44}$ Segundo Paulo Fabio, entre a eleições de 76 e 78, o grupo contava com a militância permanente de "dezenas de estudantes universitários".

Ao mesmo tempo, $O$ Constituinte ${ }^{25}$ descrevia o resultado do primeiro esforço de mobilização política pelo registro de "memoráveis conferencias dos companheiros Lisâneas Maciel e Marcos Freire, superlotando o auditório da Associação dos Funcionários Públicos, que, aliás, seria o palco das principais manifestações políticas nos últimos anos, honrando sua longa tradição democrática”. A Ala Jovem estava, na verdade, abrindo um caminho de participação política que se comprovaria extremamente amplo e proveitoso nos meses e anos seguintes.

É importante destacar o papel que assume neste momento a Associação dos Funcionários Públicos, dirigida pelo deputado Arquimedes Pereira Franco, político ligado ao senador Josaphat Marinho. Esta Associação permitiu que o movimento utilizasse suas instalaçôes como um espaço de atuação, como

\footnotetext{
${ }^{24}$ Jornal O Constituinte, v. 1, n.1, set. 1977.

${ }^{25} \mathrm{Idem}$
} 
uma espécie de sede informal de seus eventos públicos, ao passo que a coordenação se reunia nos escritórios de trabalho de seus membros, porque a sede do MDB continuava fechada para o grupo.

Na platéia dos encontros, debates e palestras realizados na Associação contava-se sempre a presença de 300 a 400 pessoas. Havia um trabalho de mobilização e atividades, como a coleta de assinaturas da campanha nacional pela anistia. A Ala Jovem articulava-se muito estreitamente com o núcleo baiano do Movimento Feminino pela Anistia - os dois movimentos tinham em comum, além da defesa da bandeira da anistia, o fato de serem fortemente influenciados pelo PCB - o que levava suas lideranças a participar de reuniōes em diversas cidades do interior da Bahia, como Jequié, Conquista, Juazeiro, Barreiras, Itaberaba, Xique-Xique, Rui Barbosa, onde eram realizados eventos e mobilizaçôes conjuntas da campanha pró-constituinte e da campanha pró-anistia ${ }^{26}$.

Em setembro de 1977, foi lançado $O$ Constituinte, órgão oficial da Ala Jovem que, por falta de recursos, limitou-se a três edições (1977, 1978 e 1979). Com 12 páginas, procurava cobrir informações de diversos segmentos, operários - principalmente químicos e petroquímicos ${ }^{27}$ - estudantes, moradores de bairros populares ${ }^{28}$ e de cidades do interior, além dos eventos conjuntos.

$\mathrm{O}$ ano seguinte trouxe novas eleições ao Senado e, desta vez, os adesistas já não tinham força para impor uma candidatura saída das suas hostes, como fora, em 1974, a de Clemens Sampaio. Agora, ao contrário, as duas candidaturas lançadas pelo $\mathrm{MDB}$ - a do economista e professor Rômulo Almeida e a do vereador de Salvador, Newton Macedo Campos - tinham um perfil nitidamente oposicionista. Em especial a de Rômulo, apoiada com grande empenho pela Ala Jovem, serviu de importante instrumento para mobilização e organização de seus primeiros núcleos orgânicos, na capital e no interior. É nessa época que a Ala Jovem começa, na prática, a funcionar como um "setor" do $\mathrm{MDB}$, ao promover filiaçoes formais específicas aos seus quadros. Era o início de um processo de institucionalização que duraria pouco mais de um ano, até que a reforma partidária compulsória, imposta pelo regime, ao final de 79, extinguindo o MDB, pusesse fim, também, à experiência da Ala Jovem.

\footnotetext{
${ }^{26}$ Paulo Fabio, janeiro de 2001.

${ }^{27}$ Sergio Santana observa que a Ala Jovem não estava presente na organização sindical, afirmando que "Em 1975 o PCB estava se estruturando fortemente na Petroquímica, com Carlos Marighela, Tiāo, Ivan Pugliese, que organizaram primeiro uma associação que virou depois o Sindicato da Indústria Química (SINDQUíMICA). Por uma questão de segurança, nós não podíamos fazer essa vinculação. O setor operário era totalmente separado”.

${ }^{28}$ Capelinha de São Caetano, Fazenda Grande do Retiro, Boca do Rio e alguns bairros da cidade baixa.
} 
Ainda em 1978, realizaram-se grandes manifestações de rua em Salvador, como a do "13 de maio" - famosa pela foto de Ulisses Guimarães enfrentando os cães policiais na Praça do Campo Grande - e a do " 2 de Julho", dia da comemoração da Independência da Bahia. Apostando na vocação popular e na mensagem simbólica de luta que caracterizam esta festa, a Ala Jovem, exibindo, à frente, Rômulo Almeida e Newton Macedo Campos, os então candidatos do MDB ao Senado, se fez presente ao cortejo - que cruza os bairros históricos da cidade, reconstruindo o trajeto dos libertadores vindos do Recôncavo, em 1823, para tomar, em definitivo, a capital, ainda em mãos dos portugueses, quase um ano depois da Proclamação da Independência do Brasil. Com isso inaugura uma tradição, até hoje mantida, de incorporação informal de partidos políticos e organizações da sociedade civil ao cortejo, postados logo após o desfile oficial, em contraponto às autoridades, cuja legitimidade era, então, contestada. Neste ano de 1978, a Ala Jovem possuía 18 núcleos em bairros de Salvador, cada um como a média de 50 filiados, e estava presente em 12 cidades do interior do Estado ${ }^{29}$.

No ano seguinte, a Ala Jovem realizou sua primeira convenção municipal da capital elegendo uma direção executiva e um conselho com o voto direto de mais de mil filiados, significando uma estruturação, a implementação de um trabalho mais orgânico. Como observa Paulo Fabio

Sim, aí teve estatuto, teve tudo. De certa maneira essa experiência foi um resgate daquela ideia inicial que era, desde os anos 72, 73, aquela ideia inicial do PCB que terminou não vingando porque a Ala Jovem foi criada em 75 como um agrupamento mais informal.

A Ala Jovem funcionava com um agrupamento de lideranças políticas que falavam pela imprensa, que utilizavam espaços importantes, como a Tribuna da Bahia, o Jornal da Bahia, e o jornal A Tarde, para divulgar as suas ações, as críticas e as denúncias da ação dos adesistas. Ao mesmo tempo, repercutiam as bandeiras de luta do MDB Nacional, como a da Assembleia Nacional Constituinte, a da democratização e a da Anistia. Durante a maior parte do tempo, a Ala Jovem funcionou à semelhança de um aparelho de sociedade civil, como uma instância da sociedade civil. Como órgão partidário

\footnotetext{
${ }^{29}$ Marcos Santana pertenceu ao PCB e no período enfocado era estudante secundarista. Entrevista realizada em abril
} de 2002 . 
institucionalizado, menos de um ano, período que será tratado a seguir, com um pouco mais de detalhe.

\section{Os grupos de esquerda e a convenção}

Gradativamente, começou a ocorrer no interior da própria Ala Jovem um movimento muito importante de aproximação de outros agrupamentos de esquerda que vinham se posicionando pelo voto nulo e de modo refratário à luta parlamentar e eleitoral. Um dos primeiros a se aproximar, como já assinalado, foi uma corrente ligada à Ação Popular (AP) que, no movimento estudantil, apresentava-se como "Nova Ação". Esse grupo se aproxima, em 1976 da campanha da Ala Jovem de Marcelo Cordeiro e em 78 já participa ativamente, inclusive lançando a candidatura do advogado Adelmo Oliveira a deputado estadual, que consegue se eleger sendo o terceiro deputado mais votado em Salvador nas eleiçôes desse ano. O mais votado foi Leonelli, com 27.761 votos em todo o Estado e 23.489 em Salvador. Filemon Matos fica em segundo lugar, com 16.717 votos em todo o Estado e 12.182 em Salvador. Todos esses candidatos possuíam sua trajetória política vinculada, de um modo ou de outro, à Ala Jovem do MDB.

Do ponto de vista histórico, a Ala Jovem do MDB e o Trabalho Conjunto são movimentos convergentes no sentido do avanço da luta oposicionista, embora tivessem ora uma relação de aliados e ora de adversários, segundo Paulo Fabio. Uma parte das forças políticas que participavam da Ala Jovem do MDB atuavam no Trabalho Conjunto, embora neste houvesse uma clara hegemonia do $\mathrm{PC}$ do $\mathrm{B}$, o qual mantinha um relacionamento de permanente tensão com as lideranças da Ala Jovem do MDB, por serem elas ligadas ao PCB. Por essas razões, o Trabalho Conjunto não estava incluído entre as frentes de trabalho prioritárias do Partido Comunista Brasileiro, que eram o MDB e sua Ala Jovem, o movimento estudantil, os setores médios e o movimento sindical (Sindiquímica). Apesar disso, na medida em que estava presente em determinados sindicatos e associação de profissionais liberais, os seus militantes terminavam também se envolvendo com o Trabalho Conjunto, embora a sua força no conjunto dessa organização fosse bem menor do que eram as da Igreja católica e a do PC do B.

Emiliano José, hoje Deputado Estadual pelo PT, acredita que a relação entre Trabalho Conjunto e a Ala Jovem era muito tênue, não contemplando açôes comuns e com a presença de uma certa animosidade devido ao fato do TC ser hegemonizado pelo PC do B, para quem o PCB, hegemônico na Ala 
Jovem, "era a pior coisa do mundo". Existia uma rigorosa separação nas ações, sendo que a Ala Jovem apoiava, por exemplo, o Movimento Feminino pela Anistia, enquanto o TC apoiava o Comitê Brasileiro pela Anistia ${ }^{30}$. Para Paulo Fábio, entretanto, o "PCB também participava do CBA, do qual vários militantes seus foram fundadores" 31 .

A partir de 1979, outros grupos de esquerda, além da já mencionada AP e de lideranças independentes que lhe eram próximas, passaram a participar da vida da Ala Jovem do MDB, a exemplo de militantes ligados ao MR8 e ao PC do B. Todas essas correntes recém-chegadas à Ala Jovem - algumas que, mais tarde, constituiriam o PT- uniram-se, no início de $1979^{32}$, e formaram uma chapa para disputar a Convençãa ${ }^{33}$ Municipal da Ala Jovem, contra a do grupo histórico, articulada pelo PCB e composta, também, por representantes de lideranças como Marcelo Cordeiro, Filemon Matos, Celso Dourado e, ainda, apoiada por outras personalidades vinculadas ao antigo Grupo Autêntico.

A chapa dos "históricos" era presidida por Sergio Santana, enquanto Emiliano José encabeçava a junção dos diversos agrupamentos de esquerda recém-chegados. Num grande debate realizado na sede do MDB, ficou claro que a coligação AP - PC do B estava na Ala Jovem, mas uma grande parte deste grupo não percebia o movimento como um espaço para construção de uma alternativa política. $\mathrm{Na}$ verdade, eles estavam ali passando o tempo até que surgisse uma outra estrutura que fosse capaz de ser mais adequada às suas

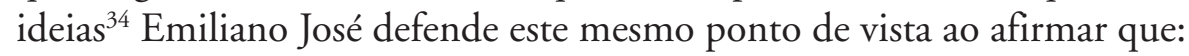

[...] para alguns [militantes de esquerda] aquilo [Ala Jovem] era simplesmente uma [...] intervenção institucional. Para outros já era a forma política de intervenção mesmo. Para uns, aquilo era um cavalo, digamos, para pensar a

\footnotetext{
${ }^{30}$ Entrevista realizada em maio de 2002.

${ }^{31}$ Paulo Fabio, janeiro de 2001.

${ }^{32}$ A reforma partidária inspirada por Golbery, neste mesmo ano, ensejaria a organização imediata do Partido do Trabalhador (PT), levando, no caso, a que AP, PC do B e MR-8 tomassem rumos diferentes Dessa coligação, o MR-8 atuou depois no Partido do Movimento Democrático Brasileiro (PMDB), permanecendo nesta legenda mesmo depois de 1985 em plena liberdade partidária. O PC do B manteve-se por um longo período no PMDB, até porque não alimentava expectativa de um novo partido, pois já tinha o seu. Dos três, apenas a AP tinha os olhos postos no que viria a ser o PT.

${ }^{33}$ Esta convenção foi organizada por uma comissão provisória que funcionou durante o ano de 1978 e que se
responsabilizou também em organizar uma convenção estadual. Era composta pelos históricos da Ala: Leonelli,
Paulo Fabio e Valdemar Oliveira, e representando o grupo dos recém-incorporados, o Prof. Ubirajara Rebouças e o
médico Luiz Fernando Pedroso.
}

${ }^{34}$ Sergio Santana, 2002. 
nossa cultura, para outros, a forma de intervir politicamente naquele momento [...] Eu, por exemplo, encarava aquilo como o espaço de intervenção política daquele momento, não o exclusivo espaço, mas o espaço importante e que tinha valor por ele próprio [...] para a AP poderia ser outra visão.

O debate, segundo os dois principais protagonistas, foi bastante acirrado e ao mesmo tempo de altíssimo nível de qualificação e politização. Duas visões de mundo se confrontaram e cristalizaram. Apesar da vitória do grupo histórico na Convenção, a composição do Conselho Diretivo da Ala Jovem municipal de Salvador já foi feita de forma proporcional, ficando cerca de 65 por cento da composição do Conselho com o grupo histórico e aproximadamente $35 \%$ com esses novos agrupamentos.

A chegada de outros grupos de esquerda à Ala Jovem pode ser atribuída a expectativa destes grupos de que o MDB poderia se voltar mais para a esquerda, devido a dois aspectos. O primeiro se refere ao conjunto de reformas nas regras do jogo político, promovida pelo regime, que levaria, na analise destes grupos, a um acirramento da divisão da sociedade. Entre as medidas adotadas estavam: a Lei Falcão de 1976, que limitava propaganda dos partidos nos meios de comunicação a apresentação de foto e currículo dos candidatos, proibindo debates e discursos e; o Pacote de Abril, que permitia que as emendas constitucionais pudessem ser aprovadas por um quorum reduzido, alem de inúmeros itens de natureza casuística, voltadas para prejudicar o MDB nas eleições.

O segundo foi a eleição de Alencar Furtado, que representava o grupo dos autênticos, e passara a ocupar a liderança do MDB na Câmara, dando ao partido uma feição mais aguerrida, como observa Maria D'Alva Kinzo (1988, p.179) a eleição de uma das suas proeminentes figuras - o deputado Alencar Furtado - para o cargo de líder do partido na Câmara Federal "desempenharia um papel importante no desenrolar dos fatos que levariam o MDB à decisão de bloquear o projeto do governo".

Todos esses fatores levaram pois, a uma postura de maior agressividade oposicionista, por parte do MDB, criando um clima que favoreceu a campanha do general Euler Bentes Monteiro às eleiçôes indiretas para a Presidência da República, obtendo, no Colégio Eleitoral, os 226 votos do MDB, enquanto João Figueiredo foi eleito presidente com 355 votos arenistas. 


\section{O fim da Ala Jovem e a criação de uma base de oposição na Bahia}

As lideranças que fundaram a Ala Jovem eram, na sua maioria, como já assinalado, membros do PCB ou egressos do Partido, o qual conservava uma certa capacidade de mobilizar estudantes. A forma como foi se constituindo, no entanto, permitiu mais o destaque de lideranças individuais que não eram propriamente do partido, com exceção do vereador Sérgio Santana e, durante parte do tempo, Domingos Leonelli que, tendo sido militante do partido desde os tempos de estudante, voltou a se organizar em 1978, depois de passar um tempo como simpatizante, porém não organizado.

Já Marcelo Cordeiro e Filemon Matos, que haviam sido líderes estudantis de massa nos anos 60, enquanto militantes do PCB, já não mais integravam os quadros do partido e, no caso de Marcelo, como no de Eduardo Saphira, outro ex-dirigente comunista importante dos anos 60, o afastamento deixara sequelas no relacionamento com a Direção Regional do PCB.

Estas diferenças geravam uma certa tensão interna dentro do núcleo original fundador da Ala Jovem, entre a corrente ligada organicamente ao Partido Comunista Brasileiro e uma outra, constituída também de políticos de formação marxista, de formação de esquerda, com posição política, em muito, convergente com as do $\mathrm{PCB}$, mas que se mantinham independentes da sua organização e das diretrizes da sua Direção. A rigor, este outro agrupamento não era uma corrente, pois entre essas personalidades e militantes que seguiam as suas respectivas lideranças havia, muitas vezes, divergências e conflitos até mais acirrados dos que o que cada uma dessas personalidades sustentava com a Direção do PCB. Isso levou, por exemplo, em determinado instante, a uma aproximação maior de Domingos Leonelli com a política do partido e até à sua reintegração orgânica, uma vez que suas divergências com Marcelo Cordeiro e o grupo que em torno deste acabou se formando passaram a ser mais relevantes.

Existia também uma outra tensão, de natureza interna ao PCB. Embora tenha participado da Ala Jovem desde o início, o Partido Comunista, num primeiro momento, resistiu um pouco à ideia da criação desse movimento porque a sua cultura era refratária à exposição de personalidades, de lideranças, como a que começou a ocorrer com Marcelo Cordeiro e outros membros do grupo. Predominava no partido a ideia de que o setor jovem mais institucional, por sua própria natureza mais coletiva, não deixaria o movimento inteiramente sob o comando de lideranças individuais.

$\mathrm{O}$ isolamento e a derrota dos adesistas, objetivos aos quais a Ala Jovem se dedicou, começou a expor um esgotamento da experiência. O MDB baiano 
estava deixando de ser adesista, já não havia o controle sobre a máquina do MDB. Rômulo Almeida já tinha se transformado numa referência importante com sua candidatura ao Senado, em 78, e estava-se às vésperas da anistia, que traria de volta outros políticos que estavam afastados da vida pública. Portanto, todos os sinais eram de que, ou a Ala Jovem se reestruturava no sentido de buscar canais de participação mais permanentes da juventude, dos segmentos estudantis, ou tenderia a se esvaziar. Com o fim do MDB e da ARENA, em 1979, as alternativas começaram a se delinear. As opções que se colocaram eram a de ir para o PMDB ou migrar para o Partido Trabalhista Brasileiro (PTB).

Esta alternativa configurou-se em razão do prestígio que Chico Pinto, embora já fosse uma liderança em declínio, demonstrou ter junto à cúpula nacional do novo PMDB, que se apresentava como o sucedâneo natural do MDB. Juntamente com o Deputado Elquisson Soares e já então mantendo relações cada vez mais próximas com o PC do B, ele obteve praticamente "carta branca" para montar o comando do novo partido na Bahia, o que pôs em pé de guerra um conjunto bem amplo de lideranças emedebistas do Estado, que ia de Josaphat Marinho - cujas relações com Chico Pinto eram reconhecidamente difíceis - a Rômulo Almeida e a Waldir Pires, recém-integrado à vida política, com naturais pretensões de liderança, passando por lideranças emergentes como Marcelo Cordeiro e Filemón Matos e pela própria Ala Jovem, enquanto movimento influenciado pelo $\mathrm{PCB}$, que depois de ter acumulado força e prestígio ao longo da década, resistia a um retorno à liderança de Chico Pinto, ainda mais se este se apresentava em posição de aliança com o $\mathrm{PC}$ do $\mathrm{B}$.

Segundo Paulo Fabio, o Partido Comunista Brasileiro (PCB) influiu junto à Ala Jovem no sentido da sua auto dissolução acreditando que como o MDB tinha acabado, acabaram-se com ele todas as suas estruturas, cabendo, na verdade, a realização de um outro trabalho de estruturação da juventude num partido para qual aquelas forças se encaminhassem. A Ala Jovem acabou sendo extinta para, supostamente, ser recriada dentro de um novo partido, mas como essa definição partidária não veio logo, ela acaba nesse momento. Na verdade a Ala Jovem foi uma vítima indireta, uma vítima secundária do golpe institucional da extinção do MDB e da Arena. Nos estados em que o PMDB herdou sem problemas a estrutura antiga do $\mathrm{MDB}$, este problema não aconteceu, mas na Bahia instalado o dilema entre PMDB e PTB, a Ala Jovem acabou sacrificada.

Emiliano Jose, porém, acredita que a experiência da Ala Jovem se esgotou naturalmente com a reforma partidária porque seu papel histórico estava encerrado. As razões que animaram a sua existência não estavam presentes ou 
não possuíam a intensidade que tinha em 1973. A juventude que poderia dar continuidade ao projeto da Ala Jovem estava envolvida com outros projetos, como a criação do PT. Os projetos políticos de esquerda vão se tornando mais nítidos, começa a se desenhar a possibilidade de legalização de certas legendas e consequentemente cada segmento vai tentando fortalecer a sua perspectiva própria.

Ernesto Laclau, analisando algumas experiências de abertura de sistemas políticos na América Latina, identifica uma tendência à substituição das mobilizações populares que se baseiam em um modelo de sociedade total ou na cristalização de um único conflito que divida a totalidade do social em dois campos opostos, por propostas mais plurais. No Brasil, o modelo Arena versus MDB começa a minar, diante da pluralidade de posições assumidas pelos sujeitos políticos e a consequente proliferação de espaços políticos. A substituição do modelo é levada a cabo tanto pela ação do regime militar, para o qual esta forma eleitoral plebiscitária já não interessava mais, quanto pela a própria sociedade política, cujos interesses, cada vez mais particularizados, não podiam conviver mais sob duas siglas partidárias apenas.

\section{O trabalho conjunto da cidade de Salvador}

Na década de 60 e mais fortemente em 70, a grande marca do movimento popular e de bairro foi dada pela Igreja, através de suas pastorais populares. Desde a década de 60, ela vinha aumentando sua presença junto às populações mais carentes através das Comunidades Eclesiais de Base, na tentativa de responder a uma crescente desparoquização. Este movimento de base resultou numa crescente autonomia e engajamento dos religiosos na militância sócio-política, posição proclamada durante a Conferência do Conselho Episcopal Latino-americano (CELAM), em 1968, em Medelin, na clássica "opção pelos pobres" e legitimada em 1979 no Documento de Puebla.

Essa nova atitude propunha uma atuação mais efetiva por parte dos religiosos, no sentido de criar condições para uma transformação efetiva do quadro de carência da população, posição próxima de um discurso mais à esquerda da "praxis transformadora". Mas, o palco das primeiras ações da Teologia da Libertação é a Juventude Universitária Católica (JUC), e não nas Comunidades Eclesiais de Base (CEB). Para alguns estudiosos do tema, como Gustavo Gutierrez, foi o contato entre algumas pastorais de setores médios, como a 
JUC, com o movimento de libertação das esquerdas brasileiras e da América Latina, que deu origem a reflexões sobre a Teoria da Libertação. A esse respeito, afirma Ilse Scherer-Warren (1984, p. 139):

Gutierrez defende uma nova forma da luta social que vem se organizando na América Latina, em especial. Um movimento que parta da vivência e da cultura popular (particularmente, da religiosidade do povo) e que construa a sua práxis com o auxílio de três fontes de reflexão: a própria vivência da opressão, o conhecimento crítico oriundo das Ciências Sociais e a mediação do discurso evangelizador da Igreja, segundo um novo método denominado Teologia da Libertação.

A partir de 1970, novos elementos vão aparecer e influir diretamente nos rumos dos movimentos populares urbanos, até então conduzidos quase que exclusivamente pela Igreja, pois com a derrota para o exército, o PCdo B vai reorientar suas ações para áreas de atuação urbana de sua penetração, como setores médios (especialmente na Bahia), já que não havia chegado a desenvolver qualquer trabalho junto aos bairros até aquela data.

O PC do B vai estimular, em Salvador, cidade onde tinha uma de suas bases mais fortes, a organização de dois segmentos: o Movimento Estudantil, chegando inclusive a dirigir o Diretório Central dos Estudantis (DCE), e, ao mesmo tempo, abrir uma frente de trabalho com os profissionais liberais. Deve ser salientado que nessa época o Partido não tinha ainda "nenhuma ideia do trabalho de bairro".

A ideia era aglutinar as diversas entidades de profissionais liberais, a fim de serem desenvolvidas ações conjuntas voltadas não só para os interesses de cada categoria como também para a luta pelas liberdades democráticas, ideia que durante a Semana do Urbanismo, promovida pelo Instituto de Arquitetos do Brasil (IAB) - seção Bahia contou com a adesão de 12 entidades (bibliotecários, médicos, odontólogos entre outros) e passando a ser denominadas de Convênio Cultural de Profissionais Liberais, nome que evita, intencionalmente, qualquer conotação política, permitindo não só uma maior aceitação pelas bases das diversas categorias, como uma maior proteção diante da repressão do Estado ainda vigente.

Com a prisão dos militantes de esquerda, estudantes, profissionais liberais, operários e artistas, em junho de 1975 e a grande mobilização diante da expulsão dos moradores do Marotinho, em março de 1976, fato que abalou a 
cidade devido à grande violência física empregada na remoção, que começa a se concretizar uma aproximação com outros segmentos da cidade.

Assim, em dezembro de 1976 é criado o chamado Trabalho Conjunto da Cidade do Salvador, com uma composição social das mais amplas, consistindo numa espécie de "pronto-socorro comunitário", diante das ameaças cada vez mais frequentes de expulsão dos moradores de locais públicos: Apesar de não ser registrada como entidade de utilidade pública, tal como o Convênio Cultural. o Trabalho Conjunto possuía um documento político, a Carta de Princípios, tendo preocupaçóes que se inspiravam na democratização política e na melhoria das condiçõos sociais do país, sendo destacadas as que se referiam a:

[...] luta pelo direito de greve; pelo direito de, sem interferência do governo. serem formadas associaçõos de bairros, sindicatos urbanos e rurais, comissões de fábrica, centro estudantil; pela livre manifestação do pensamento; contra o aumento do custo de vida, contra a falta de emprego: contra a expulsão dos camponeses de suas terras e dos moradores das invasões na cidade; pela pallicipação de todos os setores preservando a autonomia de cada.

O Convênio passou a ser dirigido por um núcleo de coordenação composto por representantes de diversos setores profissionais (profissionais liberais, estudantes, bairros, grupos religiosos, culturais, artísticos, jornais, intelectuais e parlamentares). Suas atividades ligavam-se a importantes eventos como: atos pela Anistia Ampla Geral e Irrestrita, apoio a criação de associação de moradores contra ameaças de remoção, manifestações de repúdio, apoio a movimentos sociais como Movimento feminista pela Anistia etc. Como resultado dessas ações e demandas nasce a proposta de se realizar um trabalho com as periferias, utilizando-se os espaços da Igreja.

Havia uma constante preocupação acerca da interlocução com os movimentos nacionais, como o Movimento Contra a Carestia, que teve início em São Paulo e foi trazido para Salvador por intermédio do Trabalho Conjunto. Procurando mostrar, em amplos debates, o significado da conjuntura sóciapolítica brasileira, tais preocupações foram levadas aos bairros da periferia, quando eram coletadas assinaturas reivindicando congelamento de preços e melhoria salarial. Aurélio Perez, um dos coordenadores do movimento, afirma: "ele tem caminhado nos grupos organizados, e mais nas comunidades". (PEREZ, 1978) 


\section{Considerações finais}

A lógica das ações de atores, como a Ala Jovem, não pode ser compreendida a partir de uma perspectiva da teoria liberal. Supóe-se aqui, como possível, detectar a presença de aspiraçóes a uma democracia que ia além da noção liberal de Estado de Direito, embora não deixasse de incorporá-la enfaticamente. O Partido Comunista Brasileiro para Domingos Leonelli possuía uma visão extremamente desprendida, chegando a abrir

[...] mão do controle, da sua visibilidade, da direção das coisas, do aparelhamento, em nome da acumulação. Seus integrantes acreditavam que a linha da acumulação democrática daria certo de qualquer forma, como historicamente veio a ser comprovado ${ }^{35}$.

Paulo Fábio concorda com estas afirmações e acrescenta:

É certo que apostaram na acumulação, que esse caminho foi vitorioso e que foram outros, e não o $\mathrm{PCB}$, os que se beneficiaram dos louros da vitória. Mas nada disso foi intencional, na minha opinião, mas o resultado de um jogo político, que fez do PCB um dos bodes expiatórios da abertura política. Neste sentido, o partido foi um perdedor e para essa sua derrota, num contexto de predomínio de um pragmatismo político exacerbado, contribuíram tanto razões provenientes de suas enormes virtudes republicanas como outras, decorrentes de uma cultura instrumentalizadora da política, da qual nunca pôde (ou para isso não teve tempo suficiente) se despregar inteiramente, por mais que das suas fileiras e da sua experiência tenham saído formulações como a da democracia como valor universal ${ }^{36}$

A Ala Jovem foi um movimento cuja práxis não isolava a questão democrática da questão social ou do trabalho. Esse traço decerto provinha, em grande medida, de sua íntima ligação com o PCB, não sendo à toa que foi um intelectual com raízes naquele partido que introduziu, no Brasil, ou que pelo

\footnotetext{
${ }^{35}$ Entrevista com Domingos Leonelli, jan. 2001.

${ }^{36}$ Entrevista com Paulo Fabio, maio 2002.
} 
menos formulou com objetividade e didática pioneira, a concepção de democracia como valor universal. "Nelson Coutinho era o nosso guru aqui, era o guru comum, tanto do nosso grupo como do grupo de Sergio Santana". ${ }^{37}$

Domingos Leonelli observa que "o PT se transformou naquilo que o PCB sonhou ser: um grande Partido de massa da classe operária”. Sergio Santana, no entanto, acredita que o sonho do PCB de ser um grande partido de massa se deu num contexto histórico completamente diverso do que ocorreu com o PT.

O triunfalismo nessa frase se dá apenas pelo fato de que o PT teve a condição da democracia que o PCB nunca teve. $\mathrm{O}$ PCB teve pequenos momentos de legalidade na vida do país e o PT foi feito todo ele na legalidade e num momento mundial e nacional completamente diferente. Isso não tira o mérito total do PT de ter se transformado num grande partido de massa, a ponto de que quem tem juízo hoje vota nele ${ }^{38}$.

Nem tudo o que saiu da Ala Jovem se perdeu imediatamente. Um núcleo desse conjunto de lideranças do movimento vai, mais adiante, compor, junto com outras forças e lideranças que voltaram à cena política após a anistia, um campo específico de centro-esquerda na Bahia, que vai ser responsável pela produção de experiências governamentais, no caso o Governo de Waldir Pires (1987-1989) e a gestão de Lídice da Mata, à frente da Prefeitura de Salvador (1993-1996).

Ela representou uma das principais usinas de formação de uma geração política intermediária entre aquela da dura experiência de 1964 e a atual, que se firma a partir da Constituição de 88 . Essa geração intermediária tem muito a ver com a chamada geração de 68 - muitos quadros da Ala Jovem emergem daí, dos primeiros movimentos da juventude de resistência à ditadura, nos anos 60 - mas também com aquela que despertou para a política um pouco depois, no auge dos chamados anos de chumbo.

A experiência da Ala Jovem se sobressai no campo da prática política por apresentar diversas particularidades que, apesar de estarem intrinsecamente relacionadas com a conjuntura de uma época de transição política, possuem elementos que mais tarde se tornariam triviais na política praticada por volta

\footnotetext{
${ }^{119}$ Entrevista com Domingos Leonelli, dez. 2001.

${ }^{120}$ Entrevista com Sergio Santana, 2002.
} 
da última virada de século, tais como o fenômeno da perda de referencia espacial e a importância assumida pela mídia. A atuação da Ala Jovem pode ser vista, dentro de determinados limites, como desterritorializada e, em certa medida, virtual. Tratava-se de um movimento aparentemente partidário em sua origem, devido a seus laços com o PCB e por pretender atuar no MDB, mas que na maior parte de sua existência funcionou com uma grande autonomia, fora das estruturas do partido e até de seu espaço físico. Ao mesmo tempo, a sua atuação era fundamentalmente centrada na informação e na opinião pública sem evidentemente desprezar as ações de natureza mais tradicional. Sua composição predominantemente de setores médios deu-lhe, por diversos motivos, uma visibilidade excepcional na mídia.

No que se refere à sua composição e alianças, a Ala Jovem ficou entre a ação partidária e a militância civil, o que pode ter facilitado uma certa atuação independente dos seus dirigentes, podendo até ter chegado a ocorrer práticas personalistas. Suas ações, em certa medida, somaram-se àquelas que, em todo o país, contribuíram para que o regime tivesse que lançar mão, constantemente, de medidas extraordinárias para não perder o controle da situação eleitoral, deixando evidente seu caráter autoritário, comprometendo sua busca pela "legitimidade" e favorecendo a formação de uma opinião pública a ele contrária, tudo isso terminando por acentuar o caráter plebiscitário das eleições.

A Ala Jovem, do mesmo modo que setores e departamentos jovens do MDB em outros estados, atuou, fundamentalmente "segundo a tipologia de Share e Mainwaring (1986) ${ }^{39}$ sobre os graus de controle exercidos pelas elites no processo de abertura - como um ator do tipo submetido a uma lógica de "transição pela transação", pela qual os espaços de atuação das reformas são regulados pelas elites no poder. Contudo, a atuação da Ala Jovem foi um pouco mais além, apresentando também, algumas características que não podem ser contidas estritamente nessa classificação. Em primeiro lugar porque a inclusão desse tipo de ator no cenário não pode ser explicada apenas pelo consentimento das elites autoritárias. Seu aparecimento na Bahia só se dá, efetivamente, após eleiçôes em que o desgaste do grupo no poder abre um espaço de dimensões não previstas para um avanço da "oposição consentida". O outro aspecto é que a mobilização popular, como se observou no estudo do Trabalho Conjunto da cidade do Salvador, foi um dos atores centrais no desgaste do poder.

\footnotetext{
${ }^{39}$ Para estes autores os tipos de transição são três: transição pela derrocada ou colapso do regime, que resulta do fim da capacidade de intervenção das elites autoritárias; transição por afastamento voluntário devido à escassa legitimidade e coesão interna das elites governamentais; e transição pela transação, na qual as elites regulam o ritmo das reformas e a inclusão dos demais atores.
} 


\section{REFERÊNCIAS}

BRIGAGÃO, C. A militarização da sociedade. Rio de Janeiro: Zahar,1985

FALCÃO, J. O partido comunista que conheci. Rio de Janeiro: Civilização, 1988

ESPIÑEIRA, M. Victoria. O partido, a igreja e o estado nas associações de bairros. Salvador: EDUFBA, 1997.

KINZO, M. D. G. Oposição e autoritarismo: gênese e trajetória do MDB 1966/1979. São Paulo: IDESP, 1988.

O’ Donnel, G. Autoritarismo e democratizacão. São Paulo: Vértice, 1986.

Transições, continuidade e alguns paradoxos. In: REIS, Fabio W.; O’

DONNELL Guillermo. (Org.). A democracia no Brasil: dilemas e perspectivas. São Paulo: Vértice, 1988.

SCHERER-WARREN, Ilse. Movimentos sociais. Florianópolis: USSC, 1984.

SCHWARTZENBERG, Roger-Gerard . Sociologia política. São Paulo: Difel, 1979.

SHARE, D.; MAINWARING, Scott. Transição pela transação: democratização no Brasil e na Espanha. Dados, v. 29, n. 2.1986.

SOARES, L. E. Perdão e esquecimento na Política. Notícia e Opiniāo, 3 ago. 2000.

Correiro Eletrônico.

TELLES, V. da S. Anos 70: experiências, práticas e espaços políticos. In: KOWARICK, L. (Org.). As lutas sociais e a cidade. Rio de Janeiro: Paz e Terra, 1988.

Viana, L. J. W. Liberalismo e sindicato no Brasil. 3. ed. São Paulo: Paz e Terra, 1989a. Seis teses sobre a conjuntura da transição. Revista de Politica e Cultura, Rio de

Janeiro: Centro de Pesquisa e Difusão Cultural, n. 13, maio 1989b. 


\section{2 \\ O bispo de Juazeiro e a ditadura militar}

Margarete Pereira da Silva ${ }^{2}$

O envolvimento de setores da Igreja Católica, na América Latina e, especialmente no Brasil, em questôes socais, esteve vinculado à opção preferencial pelos pobres adotada pela Conferência Episcopal de Medellín (1968) e reafirmada na Conferência Episcopal de Puebla (1979).

O contexto latino-americano exigiu um maior comprometimento da hierarquia eclesial e uma mudança na prática pastoral. A convergência de fatores externos e internos à Igreja, na conjuntura das décadas de 1960 e 1970, condicionou o surgimento e a consolidação de uma nova teologia, que fundamentada no reconhecimento da necessidade da intervenção do homem na transformação da sua história e na busca pela libertação integral significou uma nova formulação da relação fé e política.

A expressão prática desta nova Teologia, denominada Teologia da Libertação, seria a Igreja Popular, esta guiada por uma maior aproximação com o laicato, reconhecendo e valorizando os elementos da cultura popular, herança do MEB - Movimento de Educação de Base, que colocaria nas mãos dos indivíduos a

\footnotetext{
${ }^{1} \mathrm{O}$ texto é parte da dissertação apresentada ao Mestrado de História da Faculdade de Filosofia e Ciências Humanas da Universidade Federal da Bahia (Salvador-2002) com o título "Não tenho paciência histórica - a Igreja Popular em Juazeiro (BA) 1962-1982".

${ }^{2}$ Graduada em História pela Universidade Federal Fluminense. Mestre em História pela Universidade Federal da Bahia.
} 
responsabilidade na realização das transformações históricas. A Igreja Popular significaria, então, a Igreja da libertação em oposição à Igreja tradicional.

Setores da hierarquia eclesial, envolvidos em trabalhos pastorais populares, com este mesmo entendimento, comporiam o grupo progressista do episcopado, posicionando-se ao lado das lutas populares e pelos direitos humanos durante o regime militar, uma vez que, a Igreja tornou-se, neste período, a interlocutora entre a sociedade e o Estado.

No município de Juazeiro (BA) registra-se uma experiência de participação da Igreja junto à população local que evidenciou a opção preferencial pelos pobres e a opção por uma Igreja libertadora. Tratou-se da instalação da barragem e usina hidrelétrica de Sobradinho, empreendimento da Companhia Hidro Elétrica do São Francisco (CHESF), que ao deslocar setenta e duas mil pessoas, para a implantação do projeto, gerou um grave problema social ao desarticular relações de parentesco e vizinhança, cultura e, sobretudo, as atividades produtivas da população rural.

\section{A relação Igreja e Estado a partir do Golpe de 1964}

A partir de meados do século XX, o Estado brasileiro passou a definir políticas objetivando o desenvolvimento e a modernização capitalistas do país. A intervenção do Estado na economia, o desenvolvimento de uma burguesia industrial, a entrada de capitais estrangeiros dinamizaram a industrialização e o país foi gradualmente se urbanizando (cf. PATARRA, 1986; SINGER, 1986; SILVA, 1990).

Nesse contexto, tornou-se emergente a discussão acerca da questão agrária, embora o clero, em sua maioria, fosse conservador. Algumas lideranças começaram a manifestar sua preocupação com os problemas do campo. D. Inocêncio Engelke, Bispo de Campanha, Minas Gerais, em 1950, pregava a necessidade de uma reforma agrária para melhorar as condições de vida dos trabalhadores no campo. Em 1952, no documento A Igreja e o Vale do São Francisco, os bispos manifestavam a crença de que seria necessário trabalhar com o fazendeiro e ele então entenderia a necessidade de mudança nas relações no campo. Uma visão que eliminava o conflito e difundia o princípio da doutrina social da Igreja de conciliação de classes. Outro documento do episcopado de 1956, Declaração dos Bispos do Nordeste, reafirmava a crença na benevolência dos fazendeiros. Essa postura do episcopado, se por um lado, revelava a negação do conflito de classes na sociedade brasileira; por outro, ratificava a visão da incapacidade do povo conquistar seus direitos. 
Nos três primeiros anos da década de 1960, a Igreja "entra na luta para conquistar espaço político e ideológico e não perder a classe camponesa" (NOVAES, 1997, p. 33) com a missão de fazer frente ao crescimento das Ligas Camponesas e combater o fantasma do comunismo. A missão do padre era a sindicalização dos trabalhadores rurais. O "sindicato do padre" representava o acesso à "lei da nação" e atuava como controlador das açôes coletivas daqueles trabalhadores afastando a ameaça comunista.

A intervenção militar de 1964 - com seu caráter repressor - desorganizou os movimentos de trabalhadores no campo. Nos primeiros anos, a Igreja, que apoiou o golpe militar, afastou-se da questão da terra. Atemorizada com a ameaça comunista e com as manifestações que tiveram lugar nos últimos meses do governo Jango, a Igreja apoiou o golpe entendendo que era uma forma de reconduzir o país ao caminho da normalidade e da segurança e que a aliança com o Estado garantiria a missão evangelizadora.

Antes de 1964, aceitava-se quase unanimemente o fato de que uma 'ótima' relação com os poderes constitui um apoio à missão evangelizadora. No momento do Golpe, de certa forma, pode-se dizer que a Igreja e o Estado tinham objetivos comuns, a luta contra o comunismo serviu para manter a estreita colaboração e explica em parte a aceitação do fato político dos militares no poder. Mas já a partir deste momento, as lealdades vão se distanciando e o conflito interno produz grupos contrastantes na instituiçãoo eclesial.

Em maio de 1964, foi divulgado o documento Declaração da CNBB sobre a Situação Nacional, resultado de uma reunião da Comissão Central da Conferência Nacional dos Bispos do Brasil (CNBB), onde o objetivo era mostrar a necessidade pela qual passava o país de ser colocado no caminho da ordem para garantir o desenvolvimento. Era uma manifestação de apoio ao golpe militar, destacando os limites de sua atuação como o respeito às liberdades democráticas e o respeito à Igreja. Esta manifestação dá margem a pensarmos que o propósito máximo da instituição era combater toda ameaça ao seu campo de influência, neste caso específico, o ateísmo comunista. No entanto, as argumentações de Mainwaring (1989) e Lima (1979) consideram que, embora houvesse, realmente, uma preocupação da hierarquia eclesiástica com o comunismo, a instituição não apresentava uma unidade no que diz respeito ao papel social e político da Igreja na sociedade, e isto, é evidente quando distinguimos diversas correntes no seu interior. 
Já no final da década de 60, a Igreja discretamente divergia do regime militar, e em agosto de 1971, no Primeiro Congresso Católico Interamericano para o Desenvolvimento Integral do Homem, D. Hélder Câmara declarava:

Nós, cristãos, devemos ter a valentia de reconhecer que a preocupação por manter a autoridade e a ordem social nos levou a exaltar virtudes que, sendo grandes virtudes, como a paciência e aceitação de sacrifícios, na conjuntura do Continente, favoreceram os opressores, alimentaram um quase-fatalismo, contribuíram, na prática, para dar aparente razão à afirmação de Marx, transformando a religião em ópio das massas. ${ }^{3}$

A Igreja opunha-se fundamentalmente à forma da penetração do capitalismo no campo, que na sua ação devastadora, matava e expulsava homens de suas terras, e falava abertamente em redistribuição da riqueza - a terra. É importante lembrar que, na década de setenta, acelerou-se o processo de concentração de terras no Brasil. (Cf. PALMEIRA, 1994). Concomitante ao processo de concentração e ocupação de terras por grandes empresários e proprietários, no período militar, acelerava-se, também, a violência e a repressão contra toda e qualquer manifestação de oposição aos interesses do Estado. A combinação entre política agrária voltada para os interesses empresariais e repressão por parte do militares levou a oposição de setores da Igreja ao Estado.

Em 1970, a Regional Norte II da CNBB (Pará e Amapá), sob a liderança de Dom Estevão Cardoso, Bispo de Marabá (PA), divulgou documento contestando o propalado desenvolvimento da Amazônia. Diante aos conflitos nesta região, formou-se uma estrutura para dar assessoramento jurídico e estimular a formação de novos agentes pastorais. A Comissão Pastoral da Terra (CPT) foi criada em 1975 como

[...] organismo ligado à linha missionária da CNBB, tendo como objetivo central interligar, assessorar e dinamizar os que trabalham em função dos homens sem terra e dos trabalhadores rurais. ${ }^{4}$

\footnotetext{
3 "Conclusão número 1 do Encontro de Goiânia sobre a terra e Migraçóes na Amazônia Legal, junho de 1975". Cadernos de Estudos, CPT, n. 10, jul. 1984.

${ }^{4}$ Jornal $A$ Tarde, 25 ago. 1971.
} 
Em 1973, os bispos e superiores religiosos do Nordeste divulgavam o documento Eu ouvi os clamores do meu povo com dados sobre a renda per capita, trabalho, alimentação, habitação, educação e saúde, desnudando a situação de pauperização da região Nordeste. Os bispos e religiosos afirmavam que a eles não só cabia cuidar da alma, mas tratar dos problemas humanos, e na história, buscavam uma resposta para a dura realidade nordestina, concluindo que, além da marginalização regional no processo de desenvolvimento nacional, as injustiças sociais eram decorrentes de estruturas econômicas arcaicas, sobretudo no campo. A solução seria integrar o Nordeste ao projeto de desenvolvimento do país, uma vez que, a região era vista como um grave problema político e de unidade nacional, representando o atraso, o subdesenvolvimento e, a Igreja não poderia ficar indiferente ao que ocorria (cf. ROMANO, 1975).

$\mathrm{O}$ envolvimento de setores da hierarquia eclesiástica com as questóes sociais fez com que as manifestaçôes da Igreja passassem da produção de documentos às ações concretas. É o que sustenta o historiador brasilianista, Kenneth Serbin, ao afirmar que a luta pelos direitos humanos no Brasil teve início com a Igreja ${ }^{5}$. A conjuntura de repressão e perseguição a militantes de esquerda e todos aqueles que representavam ameaça a ordem instituída exigiu, tanto no campo como na cidade, um comprometimento da Igreja como defensora e mediadora da relação Estado e sociedade. Contudo, entre 1974-1978, a Igreja viveu relações tensas com o Estado - assassinatos dos padres Rodolfo Lunkebein (Mato Grosso - MT); João Bosco Penido Burnier (Ribeirão Bonito - MT); sequestro de D. Adriano Hypólito (Nova Iguaçu - RJ); conflitos sociais envolvendo populações rurais no sul do Pará e região do Araguaia-Tocantins; conflitos na Bahia, na região de Sobradinho, decorrente da instalação da barragem e usina hidrelétrica de Sobradinho.

Segundo o Governo, a Igreja Popular desafiava o poder e a ordem ao se pronunciar favorável às ações da esquerda subversiva. O ex-presidente Geisel (1974 -1978) justificou assim a restrição a alguns bispos - os dois Lorscheider, Dom Arns, Casaldáliga:

Não ficavam confinados aos seus problemas religiosos, envolviam-se em problemas que eram atribuição inerente do Estado. Tinham uma atuação nitidamente de apoio à esquerda subversiva, faziam uso da palavra contra o governo, exploravam a classe estudantil, defendiam o

\footnotetext{
${ }^{5}$ Folha de São Paulo, 7 jun. 1998. Caderno Mais. Entrevista Kenneth Serbin à época do lançamento, nos EUA, do seu livro “Justiça Social ou Subversão?” Os diálogos Secretos dos Bispos e Generais Brasileiros.
} 
asilo a subversivos, a invasão de terras, etc. (D'ARAÚJO, 1997, p. 389)

A CNBB, em outubro de 1976, publicava a Comunicação Pastoral ao Povo de Deus, cujo conteúdo tratava da violência no campo e urbana, desde censura, perseguições políticas, sequestros, até mortes de religiosos, indígenas e camponeses ocorridas na luta pela terra. Depois de descrever os acontecimentos, questionava as causas para a situação vigente, entendendo que, naquele momento, a missão da Igreja era mostrar às classes dominantes as suas responsabilidades pelos sofrimentos do povo.

Com Exigências Cristâs para uma Ordem Política (1977), a Igreja estimulava a atividade política no país e a participação dos cristãos, também definia a condição de marginalização de grande parcela da população, terminado o milagre brasileiro. Em 1980, outro importante documento A Igreja e os problemas da Terra onde aparece o princípio de que a terra é de todos e que deveria ser usada para o bem comum e não apenas para o benefício de poucos.

Com o processo de abertura política, promovida pelo regime militar no final da década de setenta, decorrente da pressão da opinião pública, a Igreja recuou do seu papel de principal mediadora entre a sociedade e o Estado, que havia exercido no período militar, uma vez que, outros sujeitos políticos, como partidos, sindicatos, Organizações Não-governamentais (ONGs), tomaram a linha de frente na luta pelos direitos humanos, pelas liberdades democráticas e pela distribuição de terra no Brasil.

\section{A Igreja Popular}

A Igreja brasileira vivenciou profundas transformaçōes em finais dos anos 60. Tais mudanças vinham sendo gestadas desde o declínio da Neocristandade que incentivou uma maior participação do laicato embora limitasse a sua ação. Organismos como a Ação Católica Brasileira (ACB) e a Juventude Universitária Católica (JUC) tiveram na atuação de seus integrantes junto aos movimentos populares, principalmente, o movimento estudantil, uma nova avaliação da integração dos católicos na vida política do país. Esses organismos buscaram conquistar autonomia frente à Igreja e parte de seus integrantes aproximou-se da esquerda. As divergências entre militantes católicos e hierarquia eclesial levaram ao afastamento de muitos ou a uma nova forma de atuar dentro da instituição. Os militantes católicos refletiam sobre o papel social e político da Igreja no mundo. Todo esse movimento de ideias foi concomitante a ebulição dos movimentos 
sociais que tiveram espaço no início de 1960 e que padeceram com a repressão do golpe de 1964. A esquerda católica, no início dos anos 60, constituiu um dos fatores singulares no desenvolvimento da Igreja brasileira.

As mudanças nas práticas pastorais e políticas não se explicam exclusivamente pelo cenário político nacional. Elas são resultantes de um complexo de transformações e articulações que também envolviam organismos eclesiásticos supranacionais e que favoreceram o trabalho de um grupo progressista do clero $^{6}$.

Lima (1979, p. 53-55) enumera os acontecimentos históricos que fortaleceram o grupo progressista: a prática política da ditadura que acelerou o processo de exploração das massas trabalhadoras, a violenta repressão, a repressão sobre a própria Igreja, o novo clima eclesiástico internacional que se criou através do Concílio Vaticano II e o fenômeno denominado "terceiromundismo", que representou um olhar da Igreja européia sobre as contradições da América Latina, em particular o Brasil; a necessidade de defender-se da repressão e a prática pastoral de ligar-se aos problemas do povo e o desenvolvimento da teologia da libertação.

Com o papado de João XXIII (1958-1963), a Igreja Católica tornou-se mais atenta ao rumo que o mundo tomara. Tornava-se necessário adequar-se ao mundo moderno e laicizado. Em seu breve pontificado, João XXIII ressaltou que a modernidade abria novos caminhos ao apostolado católico e este deveria estar atento aos novos tempos; manifestou uma preocupação com os pobres do mundo; e, pregou o ecumenismo e a colaboração entre os homens de ideologias, movimentos e partidos diferentes, mas, afinados na defesa dos direitos da pessoa e na construção de uma sociedade justa.

João XXIII convocou o Concílio Vaticano II (1962-1965), falecendo antes de sua conclusão, mas a sua realização implementou novos posicionamentos para os católicos, sobretudo a hierarquia. O Concílio propôs maior participação dos leigos, justiça social, maior sentido de comunidade, maior co-responsabilidade dentro da Igreja e relaçóes de maior proximidade entre o clero e o povo.

$\mathrm{Na}$ América Latina, principalmente no Brasil, as deliberações do Concílio Vaticano II repercutiram de forma positiva. Em 1968, realizou-se em Medellín (Colômbia), a II Conferência do Episcopado Latino-Americano (CELAM), cujo tema era A Igreja na atual transformação da América à luz do

\footnotetext{
${ }^{6}$ Os bispos progressistas reuniam-se em torno da figura de D. Hélder Câmara. Destaco também Dom José Maritano (Macapá), Dom Estevão Cardoso (Marabá), Dom Pedro Casaldáliga (São Félix do Araguaia), D. Paulo Evaristo Arns (SP), D. Adriano Hypólito (Nova Iguaçu), entre outros.
} 
Concílio, e que significou a aplicação do Concílio Vaticano II para o Continente. As conclusões do encontro representaram uma virada na prática política e pastoral da Igreja acerca da comunidade de fiéis. O princípio que tornaria essa Conferência ímpar seria a sua declaração de opção preferencial pelos pobres. O conceito de pobre para os conferencistas extrapolava a carência material. Pobre era todo aquele que também sofria com a opressão e a injustiça social.

Considerando os elementos internos e os externos podemos compreender como surgiu uma nova Igreja no Brasil, que ficou conhecida como Igreja Popular, Igreja da Libertação ou Igreja dos Pobres. Cabe alertar que a Igreja não se transformou no todo, embora insista em seu caráter universal, a instituição abriga visões diferenciadas da fé e das práticas-religiosas.

A Igreja Popular, uma comunidade de fé, esteve intimamente ligada aos movimentos sociais, sindicais e político-partidários das classes populares. Três elementos compunham sua atuação na prática política: prioridade à conscientização e organização popular de base, a afirmação das classes populares como sujeito de transformação social e econômica, e a negação do capitalismo como modelo de organização social e econômica.

A Igreja Popular pode ser definida como uma Igreja do evangelho que contesta a Igreja da tradição. É uma igreja de comunidade em oposição a uma Igreja de massa. Um catolicismo de vida comunitária onde a religião e a política se relacionam intimamente, apontando para um novo modo de ser Igreja. A espiritualidade é marcada pela ênfase na luta pela vida e pela libertação que se dá no campo histórico. Na liturgia, os objetos aparecem com uma grande carga simbólica, mais uma vez ressaltando os problemas comunitários, as lutas cotidianas (OLIVEIRA, 1992).

Para os teólogos da libertação não há libertação espiritual se não houver libertação histórica e a construção de uma vida melhor tem início na Terra sendo que a libertação só poderá ser realizada pelo homem, isto é, aquele que pode intervir na sua história. A Igreja Popular pode ser entendida como expressão prática da Teologia da Libertação.

Como estrutura de peso político, a Igreja popular contou com as Comunidades Eclesiais de Base (CEB's) que representaram a possibilidade de aproximação da Igreja a seus membros, por outro lado, a co-responsabilidade destes para a construção de uma sociedade mais justa alicerçada na fé.

Em janeiro de 1975, realizou-se o I Encontro Nacional de CEB's, onde se definiu a ação da Igreja Popular em quatro linhas. A linha política indicava que "a Igreja participe na luta pela libertação do povo, colaborando para que ele mesmo descubra as causas da opressão em que vive, denunciando toda forma de injustiça." 
As CEB's não estavam isentas de conflitos internos. O trabalho exercido pelo agente pastoral deveria respeitar e tentar superar os impasses criados por uma cultura secular de acomodação e conformação. Ao agente pastoral cabia promover a "elevação cultural das massas", a fim de favorecer a ação e a prática políticas dos grupos organizados, contribuindo para a melhoria das condiçōes de vida da comunidade em que viviam e para a superação das questôes estruturais responsáveis pela injustiça social.

As CEB's representaram, por muito tempo, a estrutura mais dinâmica da Igreja Popular, munida não apenas pela fé, mas também pelo objetivo de reorganizar e transformar a sociedade, segundo os princípios cristãos, numa nova perspectiva da relação fé e política. O elemento fundamental das CEBs era a fé inserida no mundo vivido.

A grande contribuição das CEB's para a sociedade foi estimular o exercício cotidiano da participação, das decisões coletivas e do comprometimento da ação, ou seja, o exercício das práticas democráticas.

\section{A Igreja de Juazeiro e a Barragem de Sobradinho}

Em julho de 1971, o Ministério das Minas e Energia decidiu sobre a construção da barragem de Sobradinho na divisa dos municípios de Juazeiro e Casa Nova porque esta se apresentava uma área economicamente inexpressiva, considerada das mais pobres do país (JUCA, 1982).

O relatório da Chesf indicava que a obra fazia parte do V Plano de Expansão do Sistema da empresa e seria uma das medidas tomadas para solucionar um grave problema que era o controle da grande variação da descarga do rio São Francisco entre o período das cheias e o de estiagem, que colocava em risco a operação das usinas de Paulo Afonso. ${ }^{7}$

O propósito do empreendimento foi redirecionado quando se acirrou a crise do petróleo, onde a manutenção e a instalação de termoelétricas seria mais um ônus para o Governo. Desta forma, a geração de energia, utilizando os recursos hídricos, tornava-se prioridade.

No início do ano de 1972, a Chesf lançava o edital de pré-seleção para a execução dos serviços e obras de construção do acampamento do projeto Sobradinho que compreendia entre outros itens a construção de mil residências para trabalhadores casados e alojamentos para dois mil e duzentos trabalhadores solteiros.

${ }^{7}$ CHESF. Relatório da Diretoria, exercício 1975. Recife, abr. 1976. 50 anos Chesf - Companhia Hidro Elétrica do São Francisco. 1948-1998. pp.50-51. 
A construção da barragem e a formação do lago Sobradinho cobrindo uma área de $4.250 \mathrm{Km}^{2}$ e acumulando 34 bilhôes de metros cúbicos de água impôs o deslocamento de aproximadamente setenta e duas mil pessoas que habitavam aquela região. Os municípios de Sento Sé, Pilão Arcado, Remanso e Casa Nova seriam inundados em consequência da obra.

Eunápio Peltier de Queiroz, a autoridade responsável pelo projeto, revelava preocupação com a repercussão negativa, mas controlável, que a barragem teria na região para a população ribeirinha ${ }^{8}$. Considerava que a população local era muito pobre e de hábitos de vida primitivos e não tinha capacidade e nem meios de assumir orientação própria.

Segundo dados oficiais, foram distribuídos cinco mil, setecentos e vinte lotes agrícolas, de dez hectares em média, num total de cinquenta e cinco mil, quinhentos e sessenta e seis hectares. Das setenta e duas mil pessoas que tiveram de ser reassentadas por causa da barragem, só mil famílias deveriam se estabelecer às margens do lago (PATER,1996). Para a população urbana, a transferência para os novos núcleos urbanos ocorreria de forma menos onerosa porque receberiam casas novas nas cidades recém-instaladas, os mais abastados teriam terrenos para reconstruir suas residências; a população rural, que representava pelo menos $80 \%$ da população a ser deslocada, receberia indenização. $\mathrm{E}$ aí estava o grande problema. As indenizações contemplavam, principalmente, as propriedades comprovadas por título legal e as benfeitorias. Como indenizar àqueles que não possuíam títulos de propriedade ou àqueles que tinham uma roça na ilha que pertencia a outrem?

Das 11.853 famílias atingidas pelas obras, 3.234 tinham procedência dos tradicionais centros urbanos de Sento Sé, Pilão Arcado, Remanso e Casa Nova. As 8.619 restantes eram do meio rural. A expectativa da Chesf era de que, destas últimas 5.000 iriam para a Serra do Ramalho, 1.500 permaneceriam nas proximidades do futuro lago e as restantes 2.119 adotariam soluções próprias, seguindo para áreas pára-rurais (pequenos núcleos rurais nas vizinhanças das novas cidades) ou para outras regiōes. Mas, tal expectativa reverteu-se e os dados atuais revelam que somente 1.000 estão na Serra do Ramalho, 2.000 nos núcleos pára-rurais e o restante constitui hoje o maior problema social do interior, com amplas irradiaçōes sobre outras áreas do estado?.

\footnotetext{
8 "Sobradinho vai evitar, em 1977, colapso de energia“. A Tarde, p. 3, 23 ago. 1972.

9 "Sobradinho: autoritarismo não domou o homem". A Tarde, 3 jun. 1980. Caderno 2.
} 
Os custos sociais advindos da instalação de Sobradinho mobilizaram a Igreja Católica na região e fizeram aflorar uma nova ótica na relação fé e compromisso social. É neste ínterim que a Diocese de Juazeiro assumiu o papel de interlocutora dos desalojados daquela que seria, por muito tempo, considerada a obra de orgulho da engenharia nacional. Nesses anos conturbados de ditadura militar, a relação Igreja e Estado seria, uma vez mais, abalada pela interposição da instituição religiosa junto às camadas populares contra uma empresa de caráter estatal.

Quando da instalação da barragem, estava à frente da Diocese de Juazeiro o Bispo Dom Tomás Murphy, que recebeu do Centro de Estudo e Ação Social (CEAS), informações avaliando a repercussão social do empreendimento e oferecendo assessoria. O Bispo alegou que a linha de condução da Diocese e do CEAS eram diferentes e que a solução não era criar confusão ${ }^{10}$. O Padre José Potter afirmou que

[...] eles (bispo e padres) acreditavam que a presença de um investimento daquele porte traria desenvolvimento para a região, mas que a realidade dos dias vindouros desfez as expectativas ${ }^{11}$.

A primeira manifestação da Igreja sobre o projeto Sobradinho veio através do padre irlandês João Meyers, da Paróquia de Pilão Arcado. Em carta aberta ao povo de Pilão Arcado, proclamava:

[...] Então, meus Amigos, meus Compadres e Afilhados, minha gente que eu amo: é a Vocês que quero falar. Tenho um recado pra Vocês. Eles querem botar Vocês pra fora. Por que? Dizem que será em benefício de Vocês. [...] Tem deles que dizem que vocês não valem nada, que são gentinha do chão que não produz. Pois eles se esquecem, que vocês produzem filhos para tripularem as fábricas de São Paulo, e policiarem as ruas de Belo Horizonte. E vocês têm uma coragem que eles não teriam: de labutarem no

\footnotetext{
10 “Ah, o Ceas...”. Tribuna da Bahia, p. 10, 28 out. 1980. O CEAS é uma instituição de propriedade dos Jesuítas, embora não seja uma entidade confessional, uma vez que, leigos trabalham nas equipes urbanas, de assessoria e de redação. Tem como prioridade a prática popular e as lutas sociais. Edita uma publicação, Cadernos do CEAS, desde 1969, elaborado por sacerdotes e leigos, dirigido pelo padre e teólogo Cláudio Perani. Sobre o CEAS, ver: Zachariadhes (2009).

${ }^{11}$ Entrevista com José Potter, pároco de Remanso à época da transferência dos deslocados. Juazeiro (BA). Residência Episcopal, 21 mar. 2001. Potter é americano e chegou à regiāo em 20 mar. 1966.
} 
pesado com barriga seca, ou meio cheia de pirão, de lutarem de sol a sol nos lameiros, na rede, no campo pegando boi bravo para mandar para Recife, para eles comerem carne de boi enquanto vocês enganam a fome com farinha ruim que azedou porque o velho Chico chegou ligeiro demais e molhou a mandioca...

Bem, minha gente: a nossa principal peleja é com a Chesf $[\ldots]$

Se eu tivesse a possibilidade de falar com a Chesf, eu falava assim: senhora dona Chesf, deixe de ser ruim. Troque seu coração de pedra por um de carne. Sinta o imenso prazer de ajudar gente humilde. [...]

Então, minha gente, se a Chesf fosse humana, - e não feita daquele mesmo material de que os tratores que ela usa são feitos, - ela faria o seguinte:

(a) Dar a cada beiradeiro uma casa igual, ou melhor, do que a dele, - na sede nova.

(b) Dar a cada beiradeiro uma roça igual, ou melhor, do que a dele, - nos arredores da sede nova.

(c) Indenizar, a cada um, as despesas de mudança.

(d) Sustentar a cada família pelo prazo de um ano, visto que vai perder uma safra, por causa da mudança. ${ }^{12}$

A ausência de um enfrentamento político imediato ao problema criado com a construção da barragem é analisado por Sigaud (1986), apontando entre outras razões a fragilidade da população em termos de organização. Todavia, Siqueira (1992) aponta uma concordância das principais famílias e políticos locais. De forma resumida, tendo por base o trabalho de Siqueira, poderíamos traçar o quadro político local desta forma: em Sento Sé, a família Sento Sé assumiu posição favorável; em Casa Nova, os Vianna, tomaram uma posição ambígua, pois estavam ligados ao poder estadual e federal, o Dr. Adolfo Vianna, primo do Senador Luiz Vianna Filho e irmão de Honorato Vianna,

\footnotetext{
${ }^{12}$ Pe. João Meyers. Desterro Amargo. Ao Povo de Pilão Arcado. Pilão Arcado-Ba, 1973. impresso. Arquivo particular Dom José Rodrigues de Souza.
} 
Presidente da Assembleia Legislativa da Bahia, acumulava as funções de engenheiro-residente do Departamento de Estradas de Rodagem do estado, líder político e conselheiro dos desapropriados ${ }^{13}$; em Remanso, os Braga, Rosal e Castro apresentavam posição difusa; e, em Pilão Arcado, as lideranças políticas - o prefeito nomeado João Ribeiro Vale e os Queiroz - foram os que mais benefícios obtiveram com a barragem. ${ }^{14}$

Havia, por parte dos prefeitos, uma inquietação quanto à retirada da população para outras áreas, pois isto implicaria na queda da arrecadação tributária, redução da cota no Fundo de Participação dos Municípios, que era proporcional à população e a fragmentação das suas bases eleitorais. Contudo, esses elementos não alteraram a postura dos representantes políticos locais que pouco intervieram em favor da população. Além do mais, o planejamento da ação no Vale do São Francisco sempre esteve na esfera federal, passando o poder decisório ao largo das forças políticas locais.

Quando Dom José Rodrigues de Souza, em fevereiro de 1975, assumiu a Diocese de Juazeiro, um novo cenário se estabeleceu. A Igreja que, de início, havia acreditado na obra como portadora de desenvolvimento para a região, passou a questionar o lugar ocupado pela população, principalmente a rural, no projeto em execução pela Chesf. Na prática, a Igreja de Juazeiro colocavase ao lado dos desalojados, contra a Chesf e o Estado.

Em abril de 1975, a Diocese promoveu a primeira reunião conjunta de autoridades locais, vigários e agentes pastorais com a finalidade de constituir uma Comissão. Nesse primeiro encontro, foi redigido um Memorial, com as reivindicações mais urgentes do povo, sendo enviado ao Governador do Estado, Roberto Santos, ao Diretor de Construçôes da Chesf e ao Coordenador Regional do Instituto Nacional de Colonização e Reforma Agrária (INCRA). A Comissão se instalou, de fato, em um segundo encontro, sendo o Bispo eleito presidente.

Na Assembleia Geral, em novembro de 1976, organizou-se o $1^{\circ}$ Plano de Pastoral Orgânica da Diocese, onde apareciam três metas prioritárias: a Pastoral da Mudança (das 4 cidades e dos núcleos rurais), a Pastoral da Família e a Pastoral da Terra. Uma ação mais efetiva tornava-se necessária diante de inúmeros apelos da população desassistida pela Chesf. A imprensa registrou várias

\footnotetext{
${ }^{13}$ Revista Visão, 12 maio 1975.

${ }^{14}$ Siqueira de forma geral não explicita que benefícios teriam sido esses. A única observação feita é a respeito da família Sento Sé que, de acordo com Sigaud, teria utilizado a construção da barragem como ocasião para manobras muito lucrativas aumentando seu patrimônio de "210 hectares para 3.521, no período de 1973/1977 e 1985, apenas conforme dados oficiais do INCRA".
} 
denúncias na voz do Bispo sobre as arbitrariedades cometidas pela empresa e, da mesma forma de representantes da Chesf, desmentindo as acusaçôes.

Diante do quadro crítico da região, os Bispos de Juazeiro (BA), Bonfim (BA) - Dom Jairo Ruy Matos da Silva e de Petrolina (PE) - Dom Gerardo de Andrade Pontes, reunidos em Carnaíba do Sertão (BA) elaboraram um documento analisando a situação de suas Dioceses, apontando os graves problemas que afligiam o homem do campo. O documento, Carta dos Três Bispos, tratava da atuação de empresas estatais (CHESF, Companhia de desenvolvimento dos Vales do São Francisco e do Parnaíba - CODEVASF e a Empresa Brasileira de Pesquisa Agropecuária - EMBRAPA) e particulares que, em nome do progresso, feriam os direitos humanos, sobretudo, na área rural e denunciavam, também, casos de grilagem na região. $\mathrm{O}$ documento ganhou repercussão na imprensa, levando o Cardeal Dom Avelar Brandão Vilela - Arcebispo da Bahia e Primaz do Brasil - a declarar que o assunto era de inteira responsabilidade dos Bispos que assinaram o documento.

Nesse encontro, os Bispos sentiram a necessidade da presença de um organismo que pudesse melhor assessorar a população atingida pelas questões da terra. É criada a Comissão Pastoral da Terra (CPT) em Juazeiro.

Os problemas fundiários no estado também deflagraram a instalação, pela Assembleia Legislativa baiana, de uma Comissão Parlamentar de Inquérito (CPI) da Grilagem, em setembro de $1977 .{ }^{15}$ Convocados a depor Dom Jairo Ruy Matos, em nome da Comissão Pastoral da Terra da Regional Nordeste III, e Dom José Rodrigues, Bispo de Juazeiro, traçaram um quadro dos problemas da terra no estado e em suas Dioceses.

A pressão da Igreja, Sindicatos de Trabalhadores Rurais da região e a repercussão negativa de Sobradinho na opinião pública nacional e internacional levaram, em 1978, a Centrais Elétricas Brasileira (ELETROBRAS) a elaborar o Programa de Desenvolvimento do Reservatório de Sobradinho (PDRS). Em correspondência, o Presidente da ELETROBRAS, Antonio Carlos Magalhães, comunicava a Dom José Rodrigues a aprovação do projeto (MACHADO et al., 1987).

Em junho de 1978, a Diocese de Juazeiro apresentava o documento Posição da Diocese de Juazeiro diante do Projeto Sobradinho onde afirmava que a prioridade era a terra: "lote de terra para cada família, pois é da terra que as famílias vão tirar a sobrevivência. É o mais urgente!" A Diocese esperava que o Projeto agisse como um instrumento de fixação da população desalojada e que

${ }^{15}$ Cf. “Deputados baianos expulsam colonos das terras: grilagem (multinancionais na violência)”. Jornal de Salvador, p. 12-13, 13 ago. 1977. 
contribuísse para coibir, através de mecanismos legais, a continuação da grilagem das melhores terras da região.

Os anos que se seguiram foram marcados por constantes confrontos entre a Diocese e a Chesf. A postura de Dom José e sua equipe gerariam momentos turbulentos como o da divulgação da cartilha política produzida pela Diocese em 1981. As diretrizes da Diocese fizeram com que a Igreja local se aproximasse das camadas populares, abrindo espaço para sua efetiva participação e organização. Declarada a sua opção preferencial pelos pobres, partiu em busca da construção da libertação integral do homem, incentivando uma crescente participação e comunhão do povo.

Em Juazeiro, a CPT criada em 1977 atuou em dois sentidos: numa ação curativa e numa ação preventiva. A ação curativa consistia em entrar na Justiça contra os invasores de terras e as desapropriações injustas; na ação preventiva, investiu-se na educação através de encontros e orientação à população local.

Em relatório, a CPT concluía que as reuniōes com representantes de várias comunidades favoreciam o intercâmbio de experiências, ampliavam a visão sobre os problemas do município e enfatizavam a importância da organização na defesa dos direitos da comunidade. ${ }^{16} \mathrm{~A}$ CPT investia na formação dos representantes por acreditar ser um caminho para a consolidação da organização da comunidade, bem como, uma forma de torná-la responsável pela condução e solução dos seus problemas. $\mathrm{O}$ representante escolhido pela comunidade adquiria $\mathrm{o}$ respeito da mesma e tornava-se seu interlocutor junto à Diocese e, às vezes, à entidade de classe. O objetivo da CPT era instrumentalizar o trabalhador rural para que pudesse lidar com a realidade local e nacional e, por isso, partiu sempre de problemas enfrentados pela comunidade, procurando aprofundá-los em discussões coletivas e organizando ações concretas em conjunto. Ao agente pastoral cabia o assessoramento às comunidades buscando tornar-se cada vez mais um participante, eliminando o vínculo da dependência, propiciando a autonomia da comunidade. A pastoral valorizava, sobretudo, a experiência comunitária e a descoberta do indivíduo como sujeito histórico.

Em suma, o "trabalho pastoral não visa alienar as pessoas, mas, colaborar para que as comunidades cresçam em todas as dimensões fundamentais, inclusive cresçam numa ação transformadora da realidade em que vivem". ${ }^{17}$

No período de 1975 a 1979, constituíram-se 15 regionais da CPT em todo o Brasil. Isto só foi possível nas Dioceses onde os bispos acolheram os

\footnotetext{
${ }^{16}$ Relatório de Assessoria Jurídica e Educacional da Comissão Pastoral da Terra. Juazeiro (BA), 1980.

${ }^{17}$ Idem.
} 
seus princípios e dispensaram apoio a esse trabalho pastoral. Entre esses bispos esteve Dom José Rodrigues de Souza, da Diocese de Juazeiro, na Bahia.

Dom José entrou para a congregação do Santíssimo Redentor em 1946 e até a sua nomeação para a Diocese de Juazeiro esteve envolvido, principalmente, com as questôes internas da Congregação, com a atividade de professor e como Superior Vice-Provincial, distanciado das questôes políticas que envolviam o país naqueles anos de 1960 e 1970. A nomeação para Bispo provocou uma grande mudança na sua vida. Considero esse acontecimento o marco da "conversão"18 de Dom José às causas populares. Conversão forjada na dura realidade de uma comunidade às margens do São Francisco e que sofreu as consequências do novo projeto de desenvolvimento do Estado brasileiro, durante a vigência do regime militar no país, onde estava em voga a Doutrina do Desenvolvimento e da Segurança Nacional.

Mas [...] nomeado Bispo de Juazeiro, sem saber a situação da Diocese, chego aqui, então fico sabendo dessa tal barragem de Sobradinho, e comecei a visitar aí as paróquias, era aí um clamor geral. A Diocese não estava preparada para essa luta, até na Diocese havia a ideia de que isso não era missão da Igreja. Mas, ouvi aquele clamor dos pobres, apelos dramáticos e só pude ficar ao lado deles, por opção cristã e por opção de Bispo. Então isso foi me envolvendo cada vez mais. [...] Então eu penso que essa experiência me ajudou na opção pelos pobres. [...] Então a realidade ajuda a gente a se converter numa opção assim $[\ldots]^{19}$

Na Diocese havia posicionamentos divergentes: por um lado, pessoas que acreditavam que a Igreja não deveria envolver-se na questão; por outro, agentes que entendiam que a Igreja havia falhado ao não se comprometer com aquela causa.

Em decorrência da sua opção, Dom José e a equipe da Diocese enfrentaram situações tensas e conflituosas ao longo de sua gestão. $\mathrm{O}$ apoio de religiosos e leigos foi fundamental para o desenvolvimento do trabalho pastoral. Houve um movimento da hierarquia para a base e, da mesma forma, da base para hierarquia, incidindo sobre posições e encaminhamentos desta.

\footnotetext{
${ }^{18}$ Sobre "conversão", ver Salem, 1981.

${ }^{19}$ Entrevista Dom José Rodrigues. Residência Episcopal. 17 nov. 2000. Juazeiro (BA).
} 
No desenvolvimento de suas atividades, os agentes pastorais experimentaram as dificuldades de atuar numa região dominada pelo mandonismo local, pelo caráter assistencialista dos sindicatos rurais, pela negação da elite local a atuação da Igreja voltada para as questóes sociais, pelos conflitos internos da própria pastoral e pelo número insuficiente de pessoas para a continuidade de um trabalho pastoral vinculado à prática da Igreja Popular.

Dom José sofreu ameaças de morte, uma campanha difamatória e se deparou com a pouca aceitação por parte de elite local. $\mathrm{O}$ incômodo gerado pela atuação de Dom José e sua equipe pode ser compreendido num contexto de enfrentamento que colocam em disputa projetos de desenvolvimento para o país e questionamentos às relaçôes de poder. Numa região dominada pelo poder oligárquico, sustentado pela concentração de terras e domínio eleitoral, o deslocamento de uma camada da população da órbita de influência ocasiona perda de prestígio e poder, ainda mais, quando o "queixar-se ao bispo" passa a ter outro significado e não mais a concordância deste. Por não atender mais a interesses exclusivos, a Igreja sofreu acusaçôes de subversão da ordem ao abandonar a sua missão evangelizadora e mantenedora da paz social.

A Diocese de Juazeiro, através de seus agentes pastorais, num trabalho de educação política, evidenciou a importância da organização e das ações coletivas como instrumentos de participação política na conquista de seus direitos. No âmbito da fé, ressaltou que não há contradição entre religião e o envolvimento do fiel com a política, pois as conquistas materiais que proporcionam uma vida digna e combatem a opressão são, sobretudo, libertações sócio-históricas.

A trajetória de Dom José é exemplo de como determinados setores no Brasil agiram diante das mudanças da própria instituição e de um novo olhar sobre a realidade terrena, interferindo no cotidiano da sociedade brasileira.

\section{REFERÊNCIAS}

ALVES, Maria Helena M. Estado e oposição no Brasil (1964-1984). 4. ed. Petrópolis, RJ: Vozes, 1987.

D’ARAUJO, Maria Celina. Ernesto Geisel. 3. ed. Rio de Janeiro: Fundação Getúlio Vargas, 1997.

JUCA, Joselice. Chesf: 35 anos de história. Recife: Comunicarte, 1982. 
LIMA, Luiz Gonzaga de Souza. Evolução politica dos católicos e da Igreja no Brasil: hipótese para uma interpretação. Petrópolis: Vozes, 1979.

MACHADO, Eduardo Paes at al. Poder e participação política no campo. São Paulo; Salvador: CERIFA, CAR/CEDAP-CENTRU, 1987.

MAINWARING, Scott. Igreja Católica e Política no Brasil, 1916-1985. São Paulo: Brasiliense, 1989.

NOVAES, Regina. De corpo e alma. catolicismo, classes sociais e conflitos no campo. Rio de Janeiro: Graphia, 1997.

OLIVEIRA, Pedro A. R. de. Estruturas de Igreja e conflitos religiosos. In: SANCHIS, Pierre (Org). Catolicismo: modernidade e tradição. São Paulo: Loyola, 1992.

PALMEIRA, Moacir. Burocracia, Politica e Reforma Agrária. In: MEDEIROS, Leonilde (Org.). Assentamentos rurais: uma visão multidisciplinar. São Paulo: UNESP, 1994.

PATARRA, Neide L. Dinâmica populacional e urbanização no Brasil: o período pós-30. In: FAUSTO, Boris (Dir). História geral da civilização brasileira. São Paulo: Difel, 1986. Tomo III, v. 4.

PATER, Siegfried. O Bispo dos excluidos: Dom José Rodrigues. Paulo Afonso, BA: Fonte Viva, 1996.

ROMANO, Roberto. Brasil: Igreja contra o Estado. São Paulo: Kairós, 1975.

SALEM, Helena. Brasil Igreja dos oprimidos. São Paulo: Debates, 1981.

SERBIN, Kenneth P. Diálogos na sombra: Bispos e militares, tortura e justiça social na ditadura. São Paulo: Companhia das Letras, 2001.

SIGAUD, Lygia. A dupla expropriação do campesinato e a concentração de terras em Sobradinho: Uma contribuição a análise dos efeitos da política energética do Estado. Rio de Janeiro: PPGAS/Museu Nacional/UFRJ, 1986.

Efeitos sociais de grandes projetos hidrelétricos: as barragens de Sobradinho e Machadinho. Rio de Janeiro: PPGAS/Museu Nacional/UFRJ, 1986. (Comunicação, n. 9).

SILVA, Francisco Carlos Teixeira da. A modernização autoritária: do Golpe Militar à redemocratização 1964/1984. In: LINHARES, Maria Yedda. História geral do Brasil. Rio de Janeiro: Campus, 1990.

SINGER, Paul. Interpretação do Brasil: uma experiência histórica de desenvolvimento. In: FAUSTO, Boris (Dir). História geral da civilização brasileira. São Paulo: Difel, 1986. Tomo III, v. 4.

SIQUEIRA, Ruben Alfredo de. Do que as águas não cobriram. Um estudo sobre o movimento dos camponeses atingidos pela barragem de Sobradinho. João Pessoa: UFPB, 1992.

ZACHARIADHES, Grimaldo Carneiro. CEAS: Jesuitas e o apostolado social durante a ditadura militar. Salvador: EDUFBA, 2009. 


\section{3 \\ II Congresso da Anistia: momento de resistência e definições}

Joviniano S. de Carvalho Neto ${ }^{1}$

Em 2009, comemoram-se 30 anos de dois eventos: em 28 de agosto, a concessão da anistia, dentro de uma transição programada, inicialmente pelo Regime Militar, e em novembro (15 a 18), do II Congresso Nacional de Anistia, realizado em Salvador, pelos movimentos da Anistia e setores democráticos e / ou esquerdistas da oposição que denunciaram a lei de anistia, proclamaram a sua disposição de continuar a luta pela "Anistia ampla e geral e irrestrita", fim da Ditadura Militar e ascensão das forças populares que procuravam representar. O objetivo desse trabalho é a reconstituição do II Congresso Nacional da Anistia, em momento no qual reativa-se a percepção do quanto a anistia foi incompleta e colocou em pauta questões ainda por resolver.

\section{Relembrando a luta que continua}

Não pretendemos minimizar a intensidade e dimensão da vitória do movimento de que participamos. A anistia de 1979, em função da campanha que mobilizou as forças que lutavam pela redemocratização, ultrapassou o

\footnotetext{
${ }^{1}$ Doutor em Comunicação e Cultura Contemporânea, Professor de Ciência Política da UFBA e ex-presidente do Comitê Brasileiro de Anistia (CBA-BA) - (1978-1980).
} 
pensado, inicialmente, pelo General Presidente João Figueiredo - a revisão de processos. Aliás, algo difícil de executar porque, em vários casos, não existiam propriamente processos (em lista de cassações de mandatos, por exemplo) e boa parte da sociedade não legitimava os julgamentos da Justiça Militar, quer pela rejeição aos "tribunais de Exceção", quer pelas denúncias de arbitrariedade e torturas reveladas, inclusive, em depoimentos nestes processos.

Temos consciência de que, no debate sobre o projeto da anistia, se havia um consenso sobre a necessidade de liberalização do regime, defrontavam-se duas posições. Para o governo, o projeto de anistia (e o da reorganização partidária que em parte dele dependia) era modo de preparar a transição para o que seria o restabelecimento pleno da democracia, desde que com as "salvaguardas" necessárias para manter a força (e a justificativa ideológica) do regime e acalmar sua base militar, que incluiu a promulgação de uma nova Lei de Segurança Nacional (6620/78) em dezembro de 1978 e a revogação da AI-5 em 01/01/1979. No projeto encaminhado pelo governo se excluiu, da anistia, os "crimes de sangue" e se incluiu os chamados crimes "conexos" que, segundo a interpretação que então se difundiu, incluíam todos os praticados pelos órgãos de repressão política, inclusive assassinatos, "desaparecimentos" e tortura. Enfrentando este projeto havia a mobilização da sociedade civil na qual o lema da "anistia ampla, geral e irrestrita" se tornara hegemônico e a anistia era vista como etapa necessária ao restabelecimento da democracia, ainda que a sua tradução variasse entre as varias forças sociais. Para muitos, incluiria a liberdade dos presos políticos, a reaquisição dos direitos pelos punidos por cassações ou demissões, o retorno dos exilados. Para outros, além disto, incluía punição dos torturadores, o fim de todo entulho autoritário, o esclarecimento sobre os mortos e desaparecidos.

A discussão da lei ocorreu sob grandes pressões do governo pela manutenção do seu projeto e de variadas correntes que, para ampliá-lo, criaram eventos de grande impacto que incluíram visita do Senador Teotônio Vilela às prisões, presença nas ruas e no congresso, a fuga da prisão de Theodomiro Romeiro dos Santos (o primeiro condenado a pena de morte na Ditadura Militar), às vésperas da anistia que não o beneficiaria ${ }^{2}$, a greve de fome dos presos políticos ${ }^{3}$; a apresentação, no Congresso, de emendas ao projeto de lei do governo que ampliavam a anistia.

\footnotetext{
${ }^{2}$ Sobre o caso e a fuga vide Escariz (1980) e Carvalho Neto (2000).

${ }^{3}$ A história da greve de fome dos presos políticos nos presídios brasileiros, e da solidariedade que recebeu, é objeto de Viana e Cipriano (1992).
} 
O Projeto de Lei 14/1979, antes de se transformar, provocou intensos debates. No Congresso, foram apresentadas 302 emendas. O relator, Deputado Satyro de Souza, do partido do governo (ARENA), apresentou substitutivo incorporando emendas que ampliavam a anistia ${ }^{4}$, mas mantendo o "fundamental" para a ditadura: a anistia por crimes conexos e a exclusão dos condenados pelos crimes de terrorismo, assalto, sequestro e atentado pessoal. Ao final, o projeto foi aprovado, por 206 e 201 votos, em conturbada sessão no dia 22 de agosto, e promulgado como Lei 6683, em 29 de agosto.

A partir da Lei de Anistia, das reduções e readequações das penas com base na nova Lei de Segurança Nacional e das concessões de liberdade condicional a presos políticos, a grande maioria dos exilados pôde voltar, os presos políticos saíram das prisóes, os cassados readquiriram direitos políticos, centenas de militantes saiam da clandestinidade.

Após a aprovação da Lei e do avanço no processo de liberalização, o tema se manteve na pauta política, em grande parte pela ação dos que denunciaram a anistia como incompleta e continuaram a luta nos movimentos de anistia, de direitos humanos e em organizações que os continuam ou sucedem ${ }^{5}$. A incompletude da anistia de 1979 foi comprovada pela posterior aprovação de leis que a ampliaram e políticas que procuram reparar os danos provocados pela ditadura. A Emenda Constitucional 26 de 1985 e a Constituição de 1988 ampliaram o prazo da anistia (hoje de 18/09/1946 até 05/10/1988) e os beneficiários, incluindo funcionários, dirigentes estudantis e sindicais. Em 1996, a Lei 9140 concedeu indenização a algumas famílias de mortos e desaparecidos. Em 2002, a Lei 10559 estabeleceu a admissibilidade de reparação econômica aos perseguidos políticos a ser solicitada à Comissão de Anistia, criada no Ministério da Justiça. Cerca de 60 mil pessoas requereram o reconhecimento da condição de anistiado e/ou indenização, restando, no momento em que escrevemos (março de 2009), cerca de 25 mil processos a julgar. A luta pela localização dos corpos dos "desaparecidos" políticos continuou presente, após sentença obrigando a União a fornecer informações dos arquivos que os militares alegam inexistir. A possibilidade dos torturadores serem responsabilizados, penal ou civilmente, originou açôes judiciais e despertou polêmica nacional que, incrementada em 2008, prossegue em 2009, dividindo, inclusive, ministros e órgãos do governo federal.

\footnotetext{
${ }^{4}$ Dentre elas ressalte-se a abrangência do direito a anistia até 15 de janeiro daquele ano, a anistia para crimes eleitorais, participação de estudantes, sindicalistas e empregados de empresas particulares em greves: o direito dos anistiados se inscreverem nos partidos políticos legalmente constituídos mas, sem poderem votar e serem votados (impedia candidaturas) nas convenções partidárias a se realizar em 1980.

${ }^{5}$ No caso da Bahia, o Comitê Brasileiro de Anistia (CBA) - Núcleo da Bahia, se transformou, em 1980, no Comitê de Anistia e Direitos Humanos (CADH), o qual foi sucedido, em 1995, pelo Grupo Tortura Nunca Mais (GTNM).
} 
A história da reação à anistia de 1979 e da continuidade da luta não pode ser adequadamente compreendida sem nela incluir o II Congresso Nacional da Anistia.

\section{Minimização e silenciamento}

Ocorre que se a luta, na ditadura, dos movimentos da anistia tem espaço reduzido na historiografia do período, nela praticamente não se encontram referências ao fato de que, após a anistia de agosto, realizou-se um Congresso, em novembro, que a rejeitou. A leitura de algumas obras de grande significado no campo intelectual e político ilustram estas observações.

Maria Helena Moreira Alves, no seu clássico livro Estado e oposição no Brasil (1964-1984), no item "a liberalização controlada da abertura”, dedica pouco mais de uma pagina à luta pela anistia e, apesar de criticar as limitaçóes da lei, não faz referência a que, em reação a elas, se realizou um Congresso (ALVES, 1985, p. 268-269). Thomas Skidmore, o mais conhecido dos brasilianistas, em sua obra abordando a ditadura militar, dedica cerca de cinco páginas à questão da anistia. Proclama o apoio da população à campanha, mostra o conteúdo e as limitaçôes do projeto e conclui que "os líderes da oposição sabiam que só podiam passar a um regime aberto com a cooperação dos militares" e que o processo fora mais uma lição da arte de conciliação". Antes, reconheceu que "o movimento pós-anistia não estava satisfeito com a nova lei” e clamava pela responsabilização por mortos e desaparecidos. Entretanto, não se refere a que, desta resistência, nasceu o II Congresso e a continuidade da luta (SKIDMORE, 1985, p. 422-427).

$\mathrm{Na}$ introdução de um livro da importante trilogia no qual é reconstituída a memória militar sobre a abertura, é reforçada a interpretação da anistia limitada como parte de pacto para a transição visando a liberalização do regime e a transferência do poder aos civis. "Uma proposta comum aos militares nessas negociações visa a garantir que não haverá vinganças nem revanchismos" [...] o resultado é uma série de negociações a respeito de garantias ou salvaguardas ${ }^{6}$. No Brasil, isso se revelou no debate sobre a anistia [...]. A solução encontrada foi a aplicação da anistia tanto para os que lutaram contra o regime quanto para os que reprimiram em seu nome". Apóiam, inclusive, sua posição, em citação de Ana Lagoa, em livro publicado em 1983, afirmando que

${ }^{6}$ Grifos dos autores. 
Em função da anistia e da liberdade de imprensa, nenhum militar se sentará no banco dos réus. O desagrado que isso possa provocar no meio civil é irrelevante do ponto de vista da segurança e passageiro do ponto de vista da estratégia de gradual e lenta democratização do país que não será abandonada. (SOARES; D’ARAUJO; CASTRO, 1995, p. 35-36)

Não caberia, nesta perspectiva, falar do II Congresso Nacional da Anistia, que foi expressão de uma resistência que não foi irrelevante nem passageira.

Sabemos da dificuldade da constituição da prova negativa e não cansaremos o leitor com a referência de todos os livros consultados. Um último exemplo, e que consideramos suficiente para comprovar o silenciamento sobre o II Congresso Nacional da Anistia, nos é fornecido por obra que, baseada na historiografia mais prestigiada e elaborada por críticos da ditadura, levou às bancas de jornais fascículos compondo livro sobre a ditadura militar (ARBEX JÚNIOR; SOUZA, 2007) ${ }^{7}$.

Este livro, fartamente ilustrado e dividido em matérias no estilo jornalístico, dedica duas páginas (ARBEX JÚNIOR; SOUZA, 2007, p. 362363) à luta pela anistia. As limitações são denunciadas. Matéria intitulada "quem tinha a mão mais suja de sangue não foi punido" conclui que "apesar dos protestos, envolvidos nos crimes de sangue não foram beneficiados. Mas, sim, os militares torturadores e assassinos. Se eles não cometeram os tais crimes de sangue, quem cometeu?" Titulo de outra matéria pergunta às Forças Armadas: "não vão pedir desculpas"? Os textos demonstram a insatisfação, mas contribuem para a imagem da campanha como fato histórico encerrado em agosto de 1979 e para o silenciamento da sua continuidade.

Não se pode falar em silenciamento absoluto. Encontramos referências ao II Congresso em algumas obras elaboradas, não por historiadores ou cientistas políticos, mas por militantes da luta contra a ditadura. Tarcisio Delgado (ex-deputado), em livro no qual rememora a história do Partido do Movimento Democrático Brasileiro (PMDB), traz amplo capítulo sobre a campanha pela anistia, enfatizando a participação do partido. Ao fim, informa, sem maiores detalhes: "insatisfeita a nação com os limites da Lei da Anistia aprovada, a luta prosseguiu. Nos dias 15 a 18 de novembro, em Salvador, foi realizado o II

\footnotetext{
${ }^{7}$ A leitura das "fontes consultadas" apresentadas pela publicação explica o silenciamento. Para a anistia, apóia-se, além dos livros já apresentados de Maria Helena Alves e Glauco Soares. et. alli, em dois que, enfatizando importância e limitações da anistia, a tratam como etapa vencida. Vide: Couto (1998, p. 273-279) e Ribeiro (1985, p. 23252329).
} 
Congresso Nacional pela anistia ampla, geral e irrestrita" (DELGADO, 2000, p. 196).

A Fundação Perseu Abramo, instituída pelo Partido dos Trabalhadores (PT), em livro que reúne depoimento mostrando a resistência desde o golpe até o momento em que a ditadura chega ao seu fim, incluiu amplo capitulo (DELGADO, 2000, p. 206-303) sobre a campanha pela anistia. Neste, Zilah Wendel Abramo, antiga militante do CBA/SP, em três páginas e meia, noticia e resume o significado e conclusōes do II Congresso Nacional pela Anistia. No capítulo apresenta, ainda, sessenta e três depoimentos (um de nossa lavra) nos quais se encontram algumas referências ao Congresso (MAUÉS; ABRAMO, 2006).

Finalmente, informações mais amplas são encontradas no livro Construindo a memória: a luta pela anistia na Bahia, produzido pelo Grupo Tortura Nunca Mais- Bahia (2006), sucessor, como já dito, do Comitê Brasileiro de Anistia do Estado. Neste livro, ainda que dando mais ênfase ao crescimento da luta e a documentação do I Congresso Nacional pela Anistia, em São Paulo, dedicou duas páginas e meia (BAHIA. Grupo Tortura Nunca Mais, 2006, p. 73-75) ao II Congresso. Nestas, afirma que este representou a possibilidade de um balanço dos anos da luta. Foi aberto em auditório lotado, no Colégio 2 de Julho, contou com a presença de ilustres antigos exilados, enfatizou a questão dos desaparecidos na guerrilha do Araguaia e definiu nova Comissão Executiva Nacional e os eixos norteadores da luta. Inclui, entre os depoimentos solicitados, texto de nossa autoria sobre a importância da Bahia na luta pela anistia (BAHIA. Grupo Tortura Nunca Mais, 2006, p. 97-108) no qual há três frases sobre o Congresso. Além disso, anexou algumas fotos do evento e matérias dos jornais da época e, o mais importante, a transcrição dos documentos contendo as "resoluções políticas" (BAHIA. Grupo Tortura Nunca Mais, 2006, p. 230 249) e o manifesto dos familiares dos mortos e desaparecidos na guerra do Araguaia (BAHIA. Grupo Tortura Nunca Mais, 2006, p. 225-229). Ainda que apresentadas de modo algo assistemático, é, até o presente, a maior fonte de informações sobre o II Congresso.

\section{Desafio metodológico}

Para reconstituir de modo mais sistemático o II Congresso, enfrentamos vários desafios. O primeiro era o risco de cair no memorialismo e no subjetivismo. À época, éramos membro da Coordenação Nacional da Anistia e Presidente do Comitê Brasileiro de Anistia Núcleo Bahia (CBA-BA) que assumiu a organização do Congresso. Presidimos o Congresso, especialmente as 
sessões de abertura e encerramento. Pelo desempenho no cargo, conjuntura política da época que levava a cuidados quanto a falas e exposição de algumas pessoas e pela cultura presidencialista brasileira, é compreensível que os jornalistas buscassem e apresentassem nossa fala como expressão da posição oficial do CBA e dos movimentos. Ao falar do Congresso, não podemos omitir o protagonismo que tivemos. Para enfrentar este desafio, procuramos nos basear nas notícias dos jornais da época, a partir dos quais, de algum modo, o evento foi publicizado e outras fontes verificáveis, inclusive do nosso arquivo pessoal.

O segundo desafio nos foi colocado pelo espaço definido pelo organizador para este trabalho. Assim, dividimos o texto em duas partes. Na primeira, como acabamos de fazer, procuramos inserir o tema na história e avaliação da luta pela anistia, concluindo pela necessidade de uma reconstituição do Congresso. Uma reconstituição sistemática, ainda que breve, do quadro político, estrutura, dinâmica e conclusões do Congresso é contribuição a reconstrução da história do movimento da anistia, da luta contra a ditadura militar e da participação, nelas, de evento realizado na Bahia.

\section{O II Congresso Nacional pela Anistia}

\section{Estrutura e funcionamento: breve apresentação}

O II Congresso, promovido pela Coordenação Nacional dos movimentos da Anistia e organizado pelo Comitê Brasileiro pela Anistia - Núcleo da Bahia (CBA-BA), realizou-se em Salvador, dos dias 15 a 18 de novembro de 1979. A abertura foi feita pelo Presidente do CBA-BA, Joviniano Neto, na noite do dia 15, a partir das 21 horas, no Colégio 2 de Julho, no bairro do Garcia, que cedera seu auditório, o qual transbordara diante de público estimado em mais de duas mil pessoas. Durante o dia 16 e a manhã do dia 17, os delegados participantes do Congresso, entre 700 e 800, se dividiram em oito comissões:

1. Anistia e a luta contra o aparelho repressivo;

2. Anistia e a luta dos trabalhadores da cidade e do campo;

3. Mortos e desaparecidos;

4. Presos e ex-presos;

5. Exilados e expulsos;

6. Afastados dos empregos e funções;

7. Torturados e mutilados;

8. Avaliação política dos movimentos da anistia 
Estas comissões funcionaram na Escola Experimental, situada no bairro do Matatu, região de Brotas, e apresentaram seus relatórios em duas sessões plenárias, no dia 17, no salão do Clube de Engenharia (na Avenida Carlos Gomes, Centro de Salvador). Na noite do dia 16, realizou-se missa pelos mortos e desaparecidos, no Mosteiro de São Bento, no Centro de Salvador, concelebrada por 13 sacerdotes, sob a direção do Abade D. Timóteo Amoroso Anastácio, e que foi assistida por mais de 800 pessoas.

A sessão de encerramento ocorreu na noite do dia 18 , no auditório da Associação dos Funcionários Públicos do Estado da Bahia, também superlotado (entre 1000 e 2000 pessoas) quando foi aprovado, por aclamação, extenso documento com as posiçôes tornadas consensuais em torno da rejeição da anistia parcial e prosseguimento da luta, campanhas a serem empreendidas, estrutura organizativa do movimento, reformulação partidária e lutas sociais.

Estas informações factuais já permitiriam alguma conclusão ao leitor: a luta pela anistia não se encerrou, como grande parte da historiografia deixa supor, com a anistia promulgada em 29 de agosto; o Congresso não concentrou suas atividades em um único local, mas utilizou espaços diferentes, cedidos por organizações da sociedade civil; a enumeração das comissões de trabalho apresenta não só as demandas relativas as vítimas do Regime Militar quanto a disposição de enfrentar o aparelho repressivo da ditadura, se articular com os movimentos dos trabalhadores e atuar em nova conjuntura; a aprovação, por aclamação, demonstra que, dentre os participantes do Congresso, fora alcançado um consenso.

Estes fatos, totalmente incontroversos se substituirmos as avaliações numéricas dos públicos por "espaços lotados" (o que as fotos nos jornais comprovam) são importantes, mas insuficientes para situar o congresso no momento histórico que o possibilitou e no qual as forças políticas que para ele convergiram pretendiam maximizar sua atuação. Não permitem, também, entender seu papel nas lutas da esquerda brasileira e nas condiçōes em que a luta contra a Ditadura e pela anistia continuaram até o presente.

$\mathrm{Na}$ Bahia da época, e mesmo atualmente, porque os protagonistas mais destacados continuam presentes na vida ou memória social, a simples enumeração dos locais de encontro atestava a pluralidade política do evento. $\mathrm{O}$ Colégio 2 de Julho, presbiteriano, tinha como diretor o Pastor Celso Dourado, de posição libertária e socialista. A Escola Experimental foi criada e era dirigida por Amabília Contreiras, liderança feminina e do movimento dos professores, aposentada compulsoriamente pela ditadura, comunista, casada 
com Luis Contreiras, grande referência no Partido Comunista Brasileiro. Participava do Movimento Feminino pela Anistia e do Movimento Democrático Brasileiro (MDB). Posteriormente, se elegerá vereadora de Salvador (1982) e deputada estadual (1986). O Mosteiro de São Bento acolhia e sediava movimentos de resistência à ditadura e era dirigido por $\mathrm{D}$. Timóteo Amoroso Anastásio, expressão maior, na Bahia, da renovação promovida pelo Concílio Vaticano II, tanto na linha do diálogo inter-religioso quanto da opção pelos pobres ${ }^{8}$. O Clube de Engenharia era outro centro de resistência e encontro das oposições e, na sua direção, de orientação progressista, a hegemonia tenderia para pessoas ligadas ao Partido Comunista Brasileiro (PCB). A Associação dos Funcionários Públicos era presidida por Archimedes Pedreira Franco, que liderou os funcionários públicos estaduais por muitos anos e se incluía entre os moderados do MDB, partido pelo qual se elegeu deputado estadual.

Destaque-se que muitas outras entidades colocaram seus espaços à disposição, tendo a escolha sido feita a partir da dimensão e da possibilidade de articulá-los. Isto após terem falhado nossos esforços de realizar o Congresso em único e grande espaço. Depois desta apresentação, cabe passar à reconstituição mais detalhada.

Neste trabalho, abordamos a reação ao projeto de anistia após aprovado. A reconstituição do momento anterior da luta dos movimentos de anistia e,especialmente, do CBA, permanece como demanda. Acrescente-se que este texto não tem pretensões de esgotar o tema, mas de, sumariamente, o apresentar.

\section{Gênese e motivação}

Para estabelecer a gênese e motivação do II Congresso, vale recordar que a reação dos movimentos da anistia à lei que a restringia era previsível e foi, previamente, planejada. Encaminhado o projeto do governo no dia 27 de junho e lido em sessão conjunta do Congresso, no dia 28, já no dia 29, 9 o "Encontro por Anistia e Liberdades Democráticas no Brasil”, realizado em Roma (Itália), de 28 de junho a $1^{\circ}$ de julho, lançou "Apelo à Nação". Nele, 15 núcleos do CBA na Europa, falando em nome dos exilados, conclamava a nação a se manifestar pela condenação de "projeto de anistia parcial e restrita da ditadura" e a impulsionar a luta pela Anistia

\footnotetext{
${ }^{8}$ Sobre a ação de D. Timóteo, vide Carvalho Neto (1996) e Tavares (1995).

${ }^{9}$ Texto da mensagem e projeto original encontra-se em: Brasil. Congresso Nacional (1982a, p. 21-25).
} 
Ampla, Geral e Irrestrita ${ }^{10}$. No Brasil, nos dias 7 e 8 de julho, em São Paulo, realizava-se o Encontro Nacional dos Movimentos pela Anistia, reunindo cerca de 120 delegados de mais de 20 entidades $^{11}$, que lançou o manifesto "Anistia Ampla, Geral e Irrestrita" no qual, após criticar o modelo político e econômico e a "tentativa de institucionalização do regime", concentra-se no "desmascaramento do projeto do governo" de uma anistia "parcial, limitada, discriminatória e odiosa". O manifesto era parte da estratégia aprovada de, como eixo prioritário "até a aprovação do projeto", denunciar a anistia parcial, apoiar as denúncias e posições dos presos políticos e levantar a questão dos mortos e desaparecidos. Como linha secundária que, depois da aprovação do projeto, assumiria prioridade, previa-se a denúncia da Lei de Segurança Nacional e da legislação repressiva, a capitalização política do retorno dos exilados e a colocação, perante a Nação, da situação e reivindicações dos excluídos pela Anistia ${ }^{12}$.

Atuando nesta perspectiva, nos dias 8 e 9 de setembro, dez dias depois da promulgação da lei, reuniu-se em Belo Horizonte, a Comissão Executiva Nacional (CEN) dos Movimentos da Anistia ${ }^{13}$. Nesta reunião, foram definidos 5 eixos de luta e programa das atividades para cada um deles. Os eixos foram:

1- Denúncia e combate ao sistema e aparelho de repressão política;

2- Campanha pelo esclarecimento dos mortos e desaparecidos;

3- Apoio à reintegração política, social e profissional dos anistiados;

4- Campanha pelos Excluídos da Anistia;

\footnotetext{
10 "Apelo à Nação", Roma, 29 jun. 1979, 2p. Mímeo. Documento do arquivo do autor. Os signatários foram os CBAs da Itália, Suécia (Estocolmo, Gutemburgo e Lund Malmo) Noruega, Dinamarca, Holanda, Suíça (Genebra e Lusane) Inglaterra (Londres), França (Paris), Alemanha (Colônia, Berlim - Republica Federal Alemã, Berlim República Democrática da Alemanha) e Portugal (Lisboa).

${ }^{11} \mathrm{Na}$ abertura estiveram presentes 20 entidades, 13 CDA's, 4 do MFPA e 3 movimentos pelos Direitos Humanos e Anistia. No decorrer do encontro, chegaram mais algumas. Os CBAs foram os de São Paulo, Bahia, Rio de Janeiro, Belo Horizonte, Curitiba, Piracicaba, Sorocaba, Guaratinguetá, Bauru, Juiz de Fora, Maranhão, Niterói, Goiás, Brasília, Rio Grande do Sul. Do MFPA foram as direção nacional (SP), Minas, Sergipe, Florianópolis. Dos movimentos a Sociedade dos Direitos Humanos de Alagoas, o Movimento Matogrossense de Anistia, o Comitê Bancário pela Anistia, a UBRASPEFA (militares). Arquivo do autor.

${ }^{12}$ Arquivo do autor. Anotaçôes.

${ }^{13}$ Nesta reunião, participaram representantes dos CBA-RJ, SP, Ba, MFPA, MG, Movimento Matogrossense pela Anistia e Sociedade de Direitos Humanos do Pará, membros da Executiva; representantes dos CBA - Ceará e Minas participaram como observadores.
} 
5- Vinculação com lutas populares - popularização da luta pela Anistia Ampla, Geral e Irrestrita (AAGI).

As atividades programadas para cada eixo garantiriam a continuidade da luta. Incluíam o levantamento dos não anistiados, a campanha pela libertação dos presos políticos, o apoio ao retorno, reintegração dos exilados, a definição do dia 25 de outubro como Dia Nacional dos Mortos e Desaparecidos, no qual seria entregue, pela primeira vez, os prêmios Vladimir Herzog, para as melhores matérias jornalísticas em defesa da anistia e direitos humanos, o lançamento nacional de livro sobre mortos e desaparecidos, Cabral e Lapa (1979), a realização do II Congresso Nacional pela Anistia, o enfrentamento do aparato da repressão política, denunciando a Lei de Segurança Nacional e as provocaçõos da extrema direita.

A realização do II Congresso Nacional da Anistia se incluía no quarto eixo. Salvador foi sugerida como local. A data então pensada era de 1 a 3 de novembro. A definição da pauta, objetivos e funcionamentos seriam fechados em reunião da Comissão Executiva Nacional (São Paulo, 7/10/1979) ampliada a todos os movimentos de anistia. Nela, o CBA-BA apresentaria "proposta de organização, funcionamento, finanças". Entretanto, já se podia concluir que "a nível da reunião tornou-se claro que o II Congresso será diferente do primeiro tendo como objetivos, por exemplo: a) definir o papel da Anistia no projeto popular que se contrapõe ao projeto de institucionalização do regime”, b) contribuir para a articulação dos setores sociais empenhados na transformação da natureza do regime brasileiro de repressão política e opressão econômica" ${ }^{14}$.

$\mathrm{O}$ que se desenvolvia no Brasil eram o julgamento e a condenação do Regime Militar, o que a Nota Oficial do Ministro da Aeronáutica, publicada, coincidentemente, no dia sete, ao negar, confirmava ${ }^{15}$.

A reunião, no dia 06 de outubro, concentrou-se na análise da conjuntura e na preparação do Congresso, que foi transferido para o dia 15 de novembro. As análises mostraram a mudança da conjuntura e pauta de atividades. Discutiu-se, também, como continuar a luta. Nosso registro ${ }^{16}$ recolheu temas que representam a continuidade da luta - campanha pela libertação dos presos políticos, lançamento (08/10/79) de livros sobre desaparecidos políticos ela-

\footnotetext{
${ }^{14}$ BAHIA. Comitê Brasileiro de Anistia. Reunião da Comissāo Executiva Nacional dos Movimentos da Anistia. Belo Horizonte 8 e 9/1979, 16p. manuscrito. Arquivo do autor.

15 “Délio adverte: a revolução não está em julgamento”. Folha de São Paulo, p. 4, 7 set. 1979.

${ }^{16}$ Reunião da Comissão Executiva Nacional, 6 out. 1979. Anotações do autor.
} 
borados pelo CBA-RJ e de Memórias de Gregório Bezerra, acompanhamento do caso (fuga) de Theodomiro. Mas destacam-se as atividades no retorno dos exilados, a discussão sobre a reorganização partidária que já poderia estar definida à época do Congresso e, até, a proposta da Direção Nacional do Movimento Feminino pela Anistia (MFPA) de se assumir a luta pela Assembleia Constituinte como bandeira. De outubro ao Congresso, o foco e a responsabilidade maior se transferem para Salvador e o CBA-BA.

\section{As condições do CBA-BA}

A decisão de repassar ao CBA-BA a responsabilidade de organizar e sediar o Congresso baseou-se na opinião de que teria melhores, talvez únicas, condições de fazê-los, no momento em que diminuía a presença da anistia ampla, geral e irrestrita na pauta da "grande" imprensa e em alguns setores políticos; que o foco da cobertura se voltava para cobrir o retornos dos exilados e analisar suas conseqüências para a vida política; quando, na imprensa e no campo político, a discussão sobre a reforma partidária dividia as oposições, inclusive os que atuavam no movimento da anistia.

Neste quadro, o CBA-BA mantinha seu dinamismo e capacidade de articular uma frente política para viabilizar o Congresso. A história e a composição do CBA-BA ajudam a explicar sua condição. Seu presidente, a figura mais visível, de antiga militância na esquerda, não pertencia a nenhum partido ou corrente política. Proveniente da Ação Católica e membro do Centro de Estudos e Ação Social (CEAS), tinha condições de interagir politicamente e presidir reuniões sem levar em conta a filiação dos interlocutores (aliás, na época, não se considerava necessário ou prudente explicitá-las) e mantinha relações de confiança mútua com o Cardeal D. Avelar Brandão Vilela, com o Abade D. Timóteo e outros representantes da Igreja. Na sua direção ${ }^{17}$ e base conviviam membros que teriam ligaçōes com partidos clandestinos tais como o Partido Comunista do Brasil - PC do B (o de maior participação), o Partido Comunista Brasileiro PCB (facilitava o diálogo com o MFPA da Bahia), o Partido Comunista Brasileiro Revolucionário (PCBR), de militância aguerrida. Tinha espaços para políticos do MDB - em 1978, oficialmente apoiou todos os candidatos a deputado que defendiam a anistia. Como em todo o Brasil, incorporava amigos e familiares dos presos e ex-presos políticos, mortos e desaparecidos, dentre os quais os

\footnotetext{
${ }^{17}$ A direção do CBA era composta por Joviniano Neto (Sociólogo); Paulo Martins (escritor); Ana Guedes (Assistente Social); Maria Aparecida Menezes (Arquiteta); Lúcia Simões (Geógrafa); Maria Liege Rocha de Paula (Bibliotecária).
} 
baianos que morreram na guerrilha do Araguaia. Seus membros estavam presentes e se articulavam com várias entidades e movimentos sociais.

A Bahia fornecia ainda personagens e eventos importantes na luta contra a ditadura. Nela se realizara, em setembro de 1978, presidida pelo Presidente do CBA-BA, o I Encontro Nacional dos Movimentos pela Anistia, que unificara o movimento e elegera a Comissão Executiva Nacional. Em Salvador, residia Pe. Renzo Rossi, pároco de periferia que, com credencial de D. Avelar, se transformara no visitador - e ligação - dos presos políticos do Brasil ${ }^{18}$.

A ação e integração de ex-presos políticos na Bahia eram uma base para a criação de eventos, alguns de grande repercussão, como a fuga de Theodomiro e a saída da prisão de Haroldo Lima, baiano e liderança nacional do PC do B. A Bahia tinha, ainda, uma presença na história das esquerdas do Brasil, especialmente para os militantes e simpatizantes do PCB (e partidos dele nascidos como dissidências) e do PC do B que, nela, mantinha raízes e articulação social.

Ainda que com estas condições, não foi fácil o trabalho da Comissão Organizadora do II Congresso. Nele, uma das funções que assumimos, pessoalmente, foi a de obtenção dos locais. Apesar de carta, do próprio punho, de Dom Avelar, não se conseguiu espaço que permitisse a realização em um único local. Acreditamos que agentes do governo se empenhavam em fazer recuar os responsáveis pela cessão do espaço. Caso emblemático ocorreu com o Cine Roma, à época desativado e que possuía o maior auditório privado da cidade (espaço para cerca de 1.200 pessoas). Construído pelo antigo Circulo Operário, sob inspiração de Irmã Dulce, cuja obra funcionava, como hoje, ao lado, após simpática recepção, negou o pedido, dias depois. Contatamos mais de trinta locais, não divulgamos as recusas ${ }^{19}$ e terminamos por utilizar os quatros espaços já referidos.

\section{Divulgação e preparação}

Com isso, cabe apresentar como a notícia e a preparação do Congresso ganham visibilidade na imprensa. A notícia chega aos jornais baianos no dia 10 de outubro. As noticias do Jornal da Bahia e da Tribuna da Bahia ${ }^{20}$ têm, basicamente, o mesmo conteúdo e delas selecionamos:

\footnotetext{
${ }^{18}$ Para o papel de Pe. Renzo junto aos presos políticos, vide: José (2002).

${ }^{19}$ Chegou à imprensa apenas a recusa do Instituto Social da Bahia (ISBA), escola mantida por religiosas. (Cf. MARCONI, 1979, p. 5)

20 "Congresso de Anistia em Salvador". Jornal da Bahia, Salvador, 10/10/79; "CBA: II Congresso Nacional será na Bahia em novembro", Jornal da Bahia, Salvador, 10/10/79. "Duas mil pessoas em Salvador para o Congresso pela Anistia", Tribuna da Bahia, Salvador, 10/10/79, p. 03.
} 
Salvador foi escolhida para a realização do II Congresso Nacional pela Anistia, de 15 a 18 de novembro próximo, conforme decisão tomada no último domingo durante reunião da Comissão Executiva Nacional dos Movimentos de Anistia em São Paulo. [...]

pela grande adesão verificada ao CBA-BA por parte das entidades democráticas, segundo explicação do sociólogo Joviniano Neto, presidente da secção baiana do CBA.

"Cada uma das 60 entidades de anistia do Brasil enviará dez representantes para este Congresso, estando previsto o comparecimento de cerca de duas mil pessoas. Entre os convidados estarão diversos políticos e Teotônio Vilela será particularmente homenageado pela sua luta pela Anistia e Direitos $\mathrm{Hu}$ manos. O CBA-BA, afirmou (sic) Joviniano Neto e Artur de Paula, espera que a comunidade baiana dê o mesmo apoio já demonstrado quando do Congresso da União Nacional dos Estudantes, para esta mobilização pela Anistia”.

Após esta abertura, a notícia apresenta os problemas a enfrentar. A hospedagem para o qual o Diretório Central dos Estudantes (DCE) colocara à disposição a infra-estrutura usada para "abrigar milhares de pessoas no Congresso da UNE", mas que necessitaria do apoio de toda a população e de "fazer finanças" para pagar hotéis para alguns congressistas, "principalmente os representantes de entidades internacionais". Para isto, utilizaria cartaz do artista plástico Ângelo Roberto, "feito especialmente para o evento" e se pedia o apoio do "Clube de Criação", agências de publicidade e da população.

Outro problema era o local. Anuncia que uma lista de locais fora feita e que o CBA-BA pensava em dirigir-se ao Governador do Estado "pedindo-lhe a liberação do Estádio Antonio Balbino, [...] e do Teatro Castro Alves para seu início e término".

A aventada procura do governador Antonio Carlos Magalhães era especulação sobre uma atitude que ele não tinha interesse em tomar e implícito questionamento à postura que capitalizara quando cedera espaço, prédio em construção no Centro Administrativo, para o Congresso de Reconstrução da $\mathrm{UNE}^{21}$. Nos dois jornais, a anunciada disposição de D. Avelar de intermediar para a obtenção de locais de hospedagem e reunião, e de apoiar a luta pela Anistia, não era especulação.

\footnotetext{
${ }^{21}$ Não fizemos e não recordamos que alguém tinha feito sondagem ao governador sobre o tema. À época, ACM se apresentava como radical apoiador do Presidente General Figueiredo.
} 
As matérias apresentam ainda a pauta do Congresso: Anistia e lutas democráticas, defesa dos atingidos pela repressão política, reintegração social e política dos anistiados, problemas dos desaparecidos, novos rumos da luta pela anistia ampla, geral e irrestrita.

Notícias apontando para o Congresso são, no dia 14: a divulgação do manifesto de sua convocação elaborado pela Comissão Executiva $\mathrm{Nacional}^{22}$; a nota que anuncia a presença de Jaime Guimarães, advogado de presos políticos, e de Haroldo Lima, em Seminário, no dia 24, sobre a Lei de Segurança Nacional, realizado como parte de preparação do Congresso ${ }^{23}$; o anúncio do Dia Nacional de Luta em favor dos mortos e desaparecidos quando, em São Paulo, seria concedido pela primeira vez o Prêmio Vladimir Herzog às 15 melhores matérias jornalísticas em defesa dos direitos humanos no período 1977/78 24. A matéria afirmava que essa programação culminaria com a realização do II Congresso e anunciava que, na Bahia, seria lançado cartaz com "todos os baianos, mortos e desaparecidos, durante o período de exceção política”.

Neste dia 25, quando se celebrava os 4 anos da morte de Herzog, duas decisóes eclesiásticas sobre missas pelos mortos e desaparecidos tiveram repercussão nacional. Vale uma reconstituição dos casos pela sua importância política e simbólica; pelo fato de D. Avelar Brandão Vilela, visto como moderado, ter autorizado, enquanto outra foi proibida na diocese de Recife, dirigida por D. Hélder Câmara, símbolo da resistência ao Regime Militar; por revelar como, na Bahia, os discursos e ações do CBA e da Igreja Católica, naquele tema, se articularam e, mutuamente, se legitimaram. A Arquidiocese de Recife proibiu a realização de "missa pelos mortos e desaparecidos vítimas da repressão" programada pelo CBA-PE para a Igreja de São José, D. Helder Câmara endossou a posição dos seus auxiliares:

Quando as coisas estiveram pretas, a Igreja assumiu posições e em um determinado momento chegou a ser a única voz a ser ouvida. Mas agora, já podermos ficar numa situação mais discreta, ainda mais quando sabemos que muitos estão querendo radicalizar. Não vamos, portanto, contribuir para o endurecimento do regime. E depois, missa é uma coisa muito sagrada e eu não quero ver a Igreja manipulada por um lado ou por outro.

22 "Anistia lança seu manifesto". Tribuna da Bahia, p. 3, 14 out. 1979.

23 "Anistia". Tribuna da Bahia, p. 2, 23 out. 1979.

24 “No Dia Nacional de Luta, uma homenagem a Herzog”. Tribuna da Bahia, p. 5, 25 out. 1979. 
Do modo como, na Bahia, a missa foi autorizada para o II Congresso, e da articulação entre o Cardeal e o Presidente do CBA, falam as notícias que permitem reconstruir a correspondência entre os dois ${ }^{25}$

$\mathrm{Na}$ solicitação que dirigiu ao Cardeal, o presidente do CBA/BA, Joviniano Neto, lembrava que 'a morte é momento de reflexão sobre a vida e a igualdade fundamental dos homens. A contribuição que cada homem dá à livre e dolorosa construção da história humana vinha sendo, definitivamente, inventariada e recolhida na memória e no julgamento dos contemporâneos e irmãos'. Diante disso, prosseguia Joviniano, 'uma missa pelos mortos e desaparecidos nos últimos quinze anos seria parte importante no processo de revisão da história da repressão e de sofrimento dos anos recentes no Brasil'.

D. Avelar respondeu em carta datada, coincidentemente, do dia 25 de outubro, dizendo:

Atendo, sem dificuldades, ao pedido que me dirige, pois os mortos são sempre carinhosamente tratados pela Igreja. O mistério da vida que transcende os limites do efêmero sugere e pede oraçôes, estado de alma em comunhão com a felicidade de todos os irmãos, na visão paternal e misericordiosa de Deus.

Embora saiba, continua D. Avelar, "que o movimento da anistia traz consigo uma completa carga de heterogeneidade ideológica, diante da morte entra o homem numa dimensão que só o infinito poderá julgar". Finaliza dizendo esperar "Que a celebração se revista da maior grandeza litúrgica, dentro das normas de recolhimento, piedade e, conseqüentemente, espírito religioso".

As vésperas do Congresso, artigo de D. Mariano Costa Rego, monge beneditino, busca esclarecer aos católicos a aparente contradição, afirmando que enquanto em Recife seria um ato isolado, programado à revelia da Igreja e facilmente instrumentalizado para fins ideológicos e políticos, em Salvador a

\footnotetext{
${ }^{25}$ Cf. "D. Avelar Vilela autoriza a missa por desaparecidos”. Folha de São Paulo, p. 30, 28/ out. 1979; "Presos são lembrados". Jornal da Bahia, p. 3, 28/ dez. 1979. As duas matérias tinham basicamente o mesmo conteúdo, mas com detalhamentos diferente.
} 
missa fora devidamente solicitada e autorizada pelo Cardeal, em nota oficial, mostrando a motivação do ato, que a missa de Salvador se situava em circunstâncias de dimensão nacional e "embora situada dentro do Congresso, será um ato estritamente religioso” (REGO, 1979, p. 6).

No dia 31 de outubro explode notícia de que Theodomiro havia aparecido e pedido asilo na Nunciatura Apostólica em Brasília ${ }^{26}$. Encerravam-se assim as especulações sobre seu paradeiro desde a fuga em 17 de agosto. Verificava-se que enquanto a imprensa noticiava, o governo e opinião pública acreditavam que ele estava no exterior, ele permanecera no Brasil.

Nos dias seguintes, enquanto repercutia o Decreto 84.143, de Figueiredo regulamentando a anistia (tratava basicamente das providencias para reintegração ou aposentadoria dos funcionários públicos anistiados), assinado no dia $1^{\mathrm{o}}$ de novembro, estabelecia-se polêmica sobre a concessão de salvo conduto para que Theodomiro pudesse viajar para país que lhe concedesse asilo, o que o Vaticano não podia fazer ${ }^{27}$.

No dia 05 , era noticiada a reação do Cardeal D. Avelar justificando o acolhimento na Nunciatura, e do presidente do CBA-BA defendendo a concessão do asilo por se tratar de crime político e anunciado que "o caso Theodomiro será um dos temas que despertará atenção no Congresso Nacional da Anistia" ${ }^{28}$. Na mesma página, outra matéria anunciava que, desde o dia $1^{\circ}$, a executiva do Congresso estava reunida em Salvador; veiculava a fala do Presidente da Sociedade Alagoana dos Direitos Humanos (Eduardo Bomfim) pela continuidade da luta até o fim do regime de exceção e confirmava a presença de ex-exilados no Congresso ${ }^{29}$.

No dia 11, se anuncia que as Comissões organizadoras do Congresso se reuniram no Instituto dos Arquitetos, na Ladeira da Praça (Centro de Salvador) para as últimas deliberações, entre as quais a de que a presidente de honra seria Ana da Silva, viúva de operário assassinado (Santos Dias) em São Paulo, a composição da mesa e o agradecimento ao Cardeal Brandão Vilela, que teria conseguido o Colégio 2 de Julho, "onde será a abertura e

\footnotetext{
${ }^{26}$ A noticia obteve grande destaque na imprensa nacional e local. Dois exemplos: "Theodomiro entra na Nunciatura e pede refúgio". Jornal do Brasil, p. 1, 31 out. 1979; “Theodomiro consegue asilo da Igreja em Brasília”. Tribuna da Bahia, p. 1,31 out. 1979 .

27 "Sancionada a Lei da Anistia”. Jornal da Bahia, p. 4, 21 nov. 1979; "Figueiredo regulamenta a lei de anistia". Jornal do Brasil, p. 2, 21 nov. 1979; "Salvo conduto de Theodomiro está difícil”. Tribuna da Bahia, p. 1, 3 nov. 1979.

28 “Caso Theodomiro será tema”. Tribuna da Bahia, p. 3, 5 nov. 1979.

29 “Ex-exilados presentes no Congresso de anistia”. Tribuna da Bahia, p. 3, 5 nov. 1979.
} 
o encerramento e no (sic) Instituto Social da Bahia se desenrolarão as sessões primárias" 30 .

No dia 13, às vésperas do Congresso, Marconi (1979) faz ampla matéria analisando as perspectivas do Congresso que, segundo ele, não seriam das mais animadoras, pelo esvaziamento provocado pela anistia já concedida e "por causa da nítida divisão ideológica" que viria caracterizando a maioria dos movimentos reivindicatórios (MARCONI, 1979, p. 5). Antecipou enquadramento centrado nas divergências, que adotará. No dia seguinte, prossegue enfatizando as divergências dos partidos de esquerda quanto à organização (MARCONI, 1979b, p. 3) que teriam transformado os trabalhos de preparação em "combate subterrâneo de bastidores" entre o Partido Comunista Brasileiro e o Partido Comunista do Brasil, envolvendo até membros do Partido Comunista Brasileiro Revolucionário. Quanto à posição do PCBR, cita carta de Paulo Pontes pedindo desligamento do CBA, a qual teria tido acesso e no qual criticaria a hegemonia do PC do B no CBA, ressalvando que ele não queria que fosse divulgada porque "repercussão junto ao publico poderia prejudicar o II Congresso, o que não quero de maneira nenhuma” ${ }^{31}$. Reproduz a posição do PCB, em fala do físico Roberto Argolo, no Jornal da Bahia, afirmando que Prestes teria de ser a figura central do Congresso e acusação de "simpatizantes" ${ }^{2}$ de que o Presidente do CBA estaria fazendo o jogo do $\mathrm{PC}$ do $\mathrm{B}$, porque só à noite, na reunião da Comissão Executiva Nacional da Anistia, seria definida a importância da participação de Prestes. Segundo Marconi, "o presidente do CBA baiano, cristão, nacionalista, democrata e não anti-comunista, como ele mesmo se define" estaria sob fogo cruzado ${ }^{33}$.

\footnotetext{
30 "De 15 a 18 o Congresso pela Anistia". A Tarde, p. 3, 11 nov. 1979. A matéria era imprecisa quanto ao tipo de apoio de D. Avelar e será desmentida pelos acontecimentos - as comissões não se reuniram no Instituto Social da Bahia (ISBA), nem o encerramento ocorreu no Colégio 2 de Julho.

${ }^{31}$ Um esclarecimento se impõe. A carta de Paulo Pontes revela sua insatisfação com o resultado de votação em assembléia do CBA, em caso raro, no qual se conseguiu o consenso. Fora proposto o panfleto ilustrado com caricatura de Figueiredo dando um "tiro no coco", glosando frase do General de que faria isto se ganhasse o salário mínimo. O presidente do CBA, Joviniano Neto, se opôs argumentando que o teor ultrapassava os limites de segurança, a grosseira caricatura poderia provocar reação na opinião pública e justificar a indesejada repressão. Em primeira votação, a publicação foi aprovada. Solicitada nova votação, com o retorno ao salão de membros que, momentaneamente estavam fora, foi derrotada, o que provocou a revolta de Paulo. Os que foram contra a publicação, inclusive do PCdoB, apoiaram posição originada do presidente.

${ }^{32}$ Grifo nosso.

${ }^{33}$ A síntese do jornalista, talvez não reproduza, exatamente, as palavras usadas, mas deve ser considerada correta, com o adendo que eram posições amplamente conhecidas. E que o relativo distanciamento ajudava a interlocução. Não recordamos disputas sobre Prestes, mas a conclusão de que, como um dos grandes exilados, ele teria, obviamente, lugar de honra na mesa.
} 


\section{A abertura do Congresso}

No dia 15, anunciando a abertura do Congresso, à noite, a mudança de enquadramento se revela em matérias como as resumidas a seguir.

A Tarde enfatizou o apoio de entidades internacionais, as denúncias das limitaçôes da anistia conseguida e a presença de ex-presos ${ }^{34}$. O Jornal da Babia anuncia a dimensão esperada pelo Congresso, apresenta o que seria a composição da mesa e a programação de atividades ${ }^{35}$. Em matéria cobrindo a Assembleia Legislativa, deputados denunciam perseguições políticas e realçam a importância do congresso da Anistia ${ }^{36}$.

No dia 16, a cobertura da sessão de abertura do Congresso concentra-se em Luis Carlos Prestes. Era, dos presentes, o mais proeminente dos exilados (os outros dois, Leonel Brizola e Miguel Arraes não compareceram); não vinha à Bahia, onde tinha antigos correligionários e simpatizantes, desde março de 1963; veicular sua fala no Regime Militar era um tabu que, naquele momento, a imprensa podia quebrar.

A análise das matérias de $A$ Tarde, o maior jornal baiano, é exemplificativa. A matéria específica sobre a abertura ${ }^{37}$ poderia dar outra impressão. Decompomos seu conteúdo nos seguintes tópicos.

- Instalação - "Foi instalado, às 21 horas de ontem, no auditório 2 de Julho, o Congresso Nacional pela Anistia, em sessão plenária, presidida por Joviniano Neto, do CBA da Bahia, e tendo como Presidente de Honra a viúva do metalúrgico [...] Santos Dias, que não compareceu"

- Público - "O auditório do Colégio 2 de Julho não comportou o número de participantes e curiosos [...] ficando grande parte no pátio da entrada daquele colégio"

- Participações Destacadas - "Da mesa diretora dos trabalhos, participaram representantes de todos os segmentos da sociedade que lutam pela Anistia e ainda Luis Carlos Prestes, Secretário Geral do PCB, e Diógenes Arruda, do PCB”. O jornal assinala ainda a presença do sociólogo Bayard Boiteaux (antigo dirigente do PSB), os deputados do PMDB Elquisson Soares e Marcelo Cordeiro, Pe. Renzo Rossi, representante da Conferência Nacional dos Bispos

\footnotetext{
34 “Congresso Nacional de Anistia abre debates no Colégio 2 de Julho”. A Tarde, Salvador, p. 3, 15 nov. 1979.

35 “Anistia instala hoje seu II Congresso com mais de mil pessoas”. Jornal da Bahia, Salvador, p. 2, 15 nov. 1979.

36 “Assembléia Legislativa. Engenheiro demitido de Telebahia por culpa do governador". Jornal da Bahia, p. 6, 15 nov. 1979. Os deputados que se posicionaram foram Domingos Leonelli e Adelmo Oliveira.

37 “Anistia atraiu várias lideranças comunistas”. A Tarde, 16 nov. 1979.
} 
do Brasil (CNBB), a Presidente do CBA de Minas (na verdade era do MFPA) de Minas, Helena Grecco, e o sociólogo Octávio Ianni.

A fala apresentada no texto é do Presidente do CBA: "Ao declarar aberto o II Congresso Nacional pela Anistia, Joviniano Neto disse que a luta continua e em seguida fez um relato da participação de todos os movimentos em prol da Anistia ampla geral e irrestrita e do posicionamento e luta da frente das oposiçôes durante quinze anos de arbítrio. Enfatizou que a Anistia concedida pelo sistema não reintegrou os ex-presos políticos". O presidente do conclave, Joviniano Neto, disse que "o objetivo principal do encontro é o de discutir as novas características e estratégia da luta pela Anistia, pelas liberdades democráticas e, também, contra a repressão aos movimentos reivindicatórios de operários e lavradores brasileiros". A matéria apresentava ainda a programação do Congresso.

No texto, a única referência a Prestes era a menção à sua presença na mesa. Mas a matéria foi ilustrada com foto que mostra três membros da mesa de costas para a plenária lotada com a legenda "Prestes (D) foi muito festejado na abertura do Congresso, pela Anistia” e o título já enfatizava a presença dos comunistas. Mais importante ainda, o jornal, em chamada de capa e ampla matéria cobre a recepção de Prestes no aeroporto, seu pronunciamento inicial e entrevista para a imprensa ${ }^{38}$. Sua posição era da unidade dos oposicionistas em torno do MDB, a crítica do projeto de reformulação partidária cuja essência era "a divisão das oposições e particularmente do MDB”; a rejeição à proposta de Constituinte com Figueiredo, reafirmação de posição comunista, proposição de dois pontos básicos para programa socialista: "a ação das massas porque não é empunhando fuzis que se derrubará a ditadura, pelo menos nas atuais circunstâncias, e a luta em defesa das liberdade democráticas". Quanto à Anistia, declarou: "aceitei a Anistia parcial, mas a Anistia tem que ser para todos". E garantiu que veio à Bahia participar do II Congresso Nacional pela Anistia pela certeza de que "estes movimentos de defesa da Anistia, [...], continuarão lutando pela Anistia ampla, geral e irrestrita”.

No dia 17, o Jornal da Bahia insere uma matéria ainda maior com a entrevista de Prestes, com ênfase nas divergências entre os comunistas, a oposição ao regime e à reorganização partidária. Quanto à Anistia, sublinhou que Figueiredo, que só admitia revisão de processos, "frente ao movimento de massas, foi obrigado a mudar de ideia, formulou um projeto e deu uma Anistia que

\footnotetext{
38 "Prestes agora quer mais de um partido". A Tarde, p. 1, 16 nov. 1979; "Prestes, na Bahia, prega a unidade oposicionista". A Tarde, p. 5, 16 nov. 1979.
} 
não é ampla, geral e irrestrita, é limitada, contraditória e injusta", mas os comunistas estão englobados nela ${ }^{39}$.

As divergências são também o foco do Jornal do Brasil, só que apontam para as existentes entre o CBA e o MFPA. Enquanto as Seccionais do Comitê Brasileiro pela Anistia "continuam empenhados na luta pela Anistia ampla, geral e irrestrita, o Movimento Feminino pela Anistia, segundo sua presidenta nacional, Sra. Terezinha Zerbini, está interessada em ter a capacidade de conduzir a luta para o essencial; e o essencial agora é lutar por uma Constituinte”. A Anistia concedida, apesar de injusta, teria sido ampla politicamente, o que teria transformado os movimentos de Anistia em residuais ${ }^{40}$.

\section{Funcionamento: missa e comissões}

A celebração de missa pelos mortos e desaparecidos, no dia 16, e o trabalho das comissões, neste e no dia 17 , tiveram uma cobertura menor da imprensa. A realização da missa foi reportada no bojo das matérias, mas apenas a Tribuna da Imprensa a destacará como "o ponto alto do Congresso da Bahia" ${ }^{1}$. A missa foi realizada com respeito ao rito e a partir de mensagens evangélicas associadas à anistia e à busca da justiça e liberdade, que, assim, tinham grande potencial político. Foi celebrada por D. Timóteo e mais 12 padres. A Tribuna da Imprensa ilustrou a matéria com foto da Igreja, que é das maiores da Bahia, lotada. A Tribuna da Bahia noticiou que "cerca de 800 pessoas estavam presentes". Não dominando o ritual, afirmou que "no decurso da missa, parentes dos mortos e desaparecidos fizeram uma 'chamada' simbólica citando o nome de todos os mortos e desaparecidos por questão política" ${ }^{42}$. O momento de rezar pelos "irmãos falecidos" é parte de toda missa. Inusitados eram a extensão e causa das mortes. A leitura foi momento de não só de publicização, como de unção e sacramentação religiosa.

\footnotetext{
39 “Prestes reafirma apoio à frente das oposiçōes”. Jornal da Bahia, p. 5, 17 jan. 1979.

40 "Congresso pela Anistia começa com divergências entre os participantes". Jornal do Brasil, p. 2, 16 nov. 1979. Cabe observar que os CBA's eram independentes e não Seccionais, algo similar acontecendo com o MFPA, no qual a posição de Minas (presidido por Helena Grecco) era diferente de Dona Terezinha Zerbini.

41 "Em Salvador, o II Congresso da Anistia decide lutar até soltar o último preso". Tribuna da Imprensa, p. 5, 20 nov. 1979.

42 "Anistia vai definir novas formas de luta". Tribuna da Bahia, 17/11/1979, p. 04.
} 
A cobertura do trabalho das comissões ocupou espaço pequeno. A Tribuna da Bahia antecipa conclusões já consensuais ${ }^{43}$, Jornal da Bahia e a Fotha de São Paulo sublinham que a comissão que mobilizou mais pessoas foi a da "luta dos trabalhadores da cidade e do campo". Espaço foi dado a denúncias de grilagem de terras em Sergipe (Ver: MORAES, 1979, p. 5) ${ }^{44}$. A avaliação política dos debates nas comissões aparece em matérias de avaliação do Congresso.

O Jornal da República ${ }^{45}$ manteve a ênfase nas divergências entre PCB e PC do B com o segundo "vitorioso na maioria das comissóes, impondo suas teses radicais, ainda que por votações apertadas. Como a que aprovou a proposta de criação de um tribunal popular para julgar os crimes da repressão policial, por 64 a 54". Para o jornal

[...] segundo a linha imposta pelo PC do B, os movimentos brasileiros pela anistia agora não cuidarão apenas das questôes relacionadas a presos políticos, exilados e desaparecidos, mas que darão apoio aos movimentos operários, camponês e popular.

Esta seria a solução do PC do B para enfrentar "o esvaziamento dos movimentos, a partir de anistia concedida pelo governo" que, embora restrita, "lhes tirou espaço político". Reduzir a disputa a PCB X PC do B foi posição simplista. Somava ao PC do B posiçóes de outras correntes, marxistas (como o PCBR e a Democracia Socialista) ou de outras origens e motivações. Assimila ao $\mathrm{PCB}$ posições de pessoas a ele não filiadas.

A reconstituição apesar do viés ideológico, foi melhor, realizada por jornais do PC do B e da Democracia Socialista que se incluíram entre os vitoriosos no Congresso.

Na Tribuna da Luta Operária, do PC do B, Aldo Arantes (1979, p. 2) relembra que, quanto à continuidade do movimento, haveria 3 posiçóes: 1) a vitoriosa, que defendia a continuidade do movimento pela libertação dos presos políticos, esclarecimento dos mortos e desaparecidos, responsabilização dos torturados, desmantelamento do aparato subversivo, revogação da Lei de Se-

\footnotetext{
43 “Anistia vai definir novas formas de luta". Tribuna da Bahia, 17/11/1979, p. 02.

44 “Trabalhadores e sua luta movimentam o Congresso da Anistia”. Jornal da Bahia, Salvador, p. 3, 17 nov. 1979; "Índios em pé de guerra na Região do São Francisco”. A Tarde, Salvador, p. 1, 18 nov. 1979.

45 “Anistia. O PC do B tomou conta da reunião". Jornal da República, 19/11/1979, p. 03. (Obs - matéria não assinada por Paolo Marconi).
} 
gurança Nacional e de combinar esta luta com o apoio e solidariedade às lutas populares; 2) a continuidade sem "radicalizações", diluindo a necessidade de ligação com as lutas populares; 3 ) a que enfatizava de tal modo a luta popular que deixava de lado a especificidade da luta. Nas comissóes, identificou duas outras tendências - uma que afirmava que a luta pela Anistia estava esgotada e que se deveria transformar os movimentos pela Anistia em movimentos pela Constituinte, e a outra que, a partir da necessidade de novos caminhos para a luta, propunha a articulação dos eixos anteriormente definidos com a luta em defesa dos direitos humanos. Relatou ainda a discussão sobre a criação do Tribunal Popular, cuja conclusão seria a busca de condiçôes para criá-lo e a decisão de não se posicionar sobre a campanha pela Assembleia Constituinte, mas de barrar qualquer forma de institucionalização do regime. O jornal Em Tempo, porta voz da Democracia Socialista, enfatizou a resposta política dada aos que julgavam o movimento moribundo, apostavam no seu esvaziamento e celebrou a mudança do eixo da luta pela anistia pela ligação mais orgânica aos movimentos populares e democráticos, inclusive na luta contra a violência policial. Na capa, o que teria sido o destaque maior - a criação de um Tribunal de Julgamento Político dos Crimes da Ditadura, proposta que defendera ${ }^{46}$.

\section{O encerramento}

A imprensa avaliou o Congresso e apresentou a sessão de encerramento. A mais ampla cobertura foi a da Tribuna da Bahia. Uma matéria de mais de 1/4 da página, no dia 19, e outra, de página inteira, no dia 20, ilustrada por grande fotografia de plenária na Associação dos Funcionários Públicos ${ }^{47}$.

$\mathrm{Na}$ primeira, a cobertura dá ênfase à sessão de encerramento. A composição de mesa, com a presença da Presidente de Honra do Congresso, Ana Maria do Carmo Silva, a viúva do operário Santos Dias, o senador Teotônio Vilela (MDB) e o Presidente do CBA-BA, Joviniano Neto, e as falas dos dois últimos sob o titulo "D. Quixote do futuro". Apresenta a dura fala do senador, que iniciou dizendo: "estar solidário com os movimentos pró-anistia por se tratarem de levantes populares contra o arbítrio". Alguns trechos mostram a contundência da fala do Senador

\footnotetext{
46 “O II Congresso Nacional da Anistia decide: Tribunal Popular para julgar Torturadores”. Em Tempo, 91, São Paulo, p. 1, 22 a 28 nov. 1979. Ver: Oliveira (1979, p. 50).

47 “Congresso da Anistia é encerrado". Tribuna da Bahia, Salvador, p. 6, 19 nov. 1979; "Congresso propõe continuidade da luta por uma anistia geral”. Tribuna da Bahia, Salvador, p. 9, 20 nov. 1979.
} 
[...] acusou ainda o sistema 'criminoso', dirigindo-se especialmente à viúva do operário paulista.'A cada passo estamos nos encontrando com episódios como esse. Mas,hoje, em qualquer recanto desse país, já existem os movimentos pela anistia'. Ele contesta mais uma vez o regime político do Brasil, afirmando que 'essa abertura é um rolo de engodo', explicando em seguida que, se fosse o contrário, não era preciso a formação de movimentos pela anistia, pois esse é um direito de todo o cidadão e, portanto, não precisa ser reivindicado'. 'É indispensável culpar o governo pelo desaparecimento e pelas mortes do nosso povo ocorridos por atos do arbítrio. Temos que tirar os nossos presos das cadeias e exigir que o governo dê conta dos desaparecidos e que devolva os cadáveres aos seus familiares. Tenho recebido mais de 300 cartas do exterior pedindo explicações sobre as pessoas que continuam presas e sobre a reintegração dos que foram libertados.

A seguir, Joviniano Neto agradeceu as palavras do senador e tratou-o como o 'D. Quixote da liberdade e do futuro', explicando que 'ele conta com o apoio popular'. Ao mesmo tempo, o Presidente do CBA da Bahia denunciou também os boicotes que 'a direita' tentou fazer contra a realização do Congresso, dificultando o processo para se conseguir um local. 'Houve ainda pregação de panfletos no Colégio Dois de Julho, querendo jogar os pais dos alunos contra nós, cartas ameaçadoras a Ronilda Noblat e outros participantes do Congresso'.

Uma das propostas do Congresso, enfatizada por Joviniano, refere-se a um levantamento sobre documentos em escritura, para a responsabilidade judicial dos autores de crimes e torturas perante a sociedade nacional e internacional. 'No futuro, inclusive, poderá transformarse num Tribunal Bertrand Russel, a depender das decisões do povo.

Ainda sobre a plenária de encerramento, noticia o depoimento de expreso, Milton Coelho que, pelas torturas, ficou cego. No restante da matéria, abriu subtítulo para os familiares dos mortos e desaparecidos do Araguaia, 
estudo sobre a tortura apresentada pelo Núcleo dos Profissionais da Saúde do CBA-SP e para avaliação positiva do Congresso por Diógenes Arruda.

A matéria do dia 20 é sobre a reconstituição do congresso, com os seguintes pontos: o tema central e a finalidade; as conclusões das comissões e da plenária, a reunião de líderes da esquerda e de personalidades ligadas à luta pela anistia; as decisões da plenária sobre quem tinha direito a voto (aceitou o voto de oposiçôes sindicais em sindicato metalúrgicos da Bahia, São Paulo e Volta Redonda e recusou à Convergência Socialista).

$\mathrm{Na}$ sessão de encerramento, consideramos ainda necessário destacar a divulgação da carta enviada por Theodomiro ao Congresso, o Manifesto dos familiares dos mortos e desaparecidos no Araguaia e duas falas emblemáticas a da presidente de honra, Ana Silva, denunciando a repressão contra os operários, e a de encerramento, feita por Luis Eduardo Greenhalg, Presidente do CBA-SP que, em nome de todos os movimentos de anistia, reafirmou a disposição de continuar a luta.

Resultado maior do encerramento foi a aprovação unânime do seu relatório final. O espaço previsto para este trabalho não permite a reprodução de suas 11 páginas. Assim, não resumiremos as 25 moções aprovadas denunciando a repressão e defendendo os movimentos populares, nem as 30 de apoio que o Congresso recebeu. Nem as decisões sobre estrutura organizativa que se inviabilizaram no ano seguinte. Nem mesmo as resoluções políticas definindo as lutas e campanhas cujas objetivos, na história, foram alcançados ou continuam sendo perseguidos.

O parágrafo que encerra o manifesto "A luta continua", que antecede as "resoluções políticas", é suficiente para exprimir a disposição dos militantes da anistia:

Todos esses crimes hão de ser julgados. Julgados pela opinião pública nacional e internacional, julgados pela consciência democrática do país, julgados pelo povo brasileiro. As prisões, as torturas, as mutilações, os desaparecimentos e os assassinatos não ficarão impunes. A conquista da Anistia Ampla, Geral e Irrestrita não permitirá que uma gota de sangue tenha sido derramada em vão.

Esta disposição foi chave para que, no Brasil, a partir de 1979, se mudasse o significado etimológico da palavra Anistia que, ao invés de esquecimento, assumiu o de memória e julgamento da ditadura militar. 


\section{REFERÊNCIAS}

ALVES, Maria Helena Moreira. Estado e oposição no Brasil (1964-1984). Tradução de Clovis Marques. 3. ed. Petrópolis, RJ: Vozes, 1985. p. 268-269.

ARANTES, Aldo. Libertar até o último preso. Tribuna da Luta Operária, São Paulo, p. 2, 24 nov. 1979.

ARBEX JÚNIOR, José; SOUZA, Hamilton Octavio. A ditadura militar no Brasil: a história em cima dos fatos. São Paulo: Casa Amarela, 2007. 383p. (Coleções Caros Amigos).

BAHIA. GRUPO TORTURA NUNCA MAIS. Construindo a memória: a luta pela anistia na Bahia. Salvador, 2006, 286p. Organizadoras: Ana Guedes; Lucimar Silva Cunha Mendonça.

BRASIL. Congresso Nacional. Comissão Mista Sobre Anistia. Anistia: documentário organizado por determinação do Presidente da Comissão Mista do Congresso, Senador Teotônio Vilela. Brasília-DF, 1982a. 766p. v. 1. p. 21-25.

BRASIL. Congresso Nacional. Comissão Mista Sobre Anistia. Documentário organizado por determinação do Presidente da Comissão Mista do Congresso, Senador Teotônio Vilela. Brasília-DF, 1982b. 560p. v. 2

CABRAL, Reinaldo; LAPA, Ronaldo (Org.). Desaparecidos politicos: prisões, seqüestros, assassinatos. Rio de Janeiro: Opção: CBA, 1979. 287p.

CARVALHO NETO, Joviniano Soares de. Theodomiro: os limites da midia e da anistia: a imprensa baiana e o primeiro condenado a morte na República. 502f. 2000. Dissertação (Mestrado em Comunicação e Cultura Contemporânea) - Faculdade de Comunicação, Universidade Federal da Bahia, Salvador, 2000. (Org.). D. Timóteo: presença histórica. Salvador, Envelope, 1996. 61p

COUTO, Ronaldo. História indiscreta da ditadura e da abertura. Rio de Janeiro: Record, 1998. 516p.

DELGADO, Tarcisio. A história de um rebelde: 40 anos, 1966-2000. Brasília: Fundação Ulisses Guimarães, 2000. 421p.

DEPARTAMENTO INTERSINDICAL DE ASSESSORIA PARLAMENTAR. Quem foi quem na Constituinte: nas questôes de interesse dos trabalhadores. São Paulo: Cortez: Oboré, 1988. 664p.

ESCARIZ, Fernando. Porque Theodomiro fugiu. São Paulo: Global, 1980. 92p.

JOSÉ, Emiliano. As asas invisiveis de padre Renzo: uma história singela de amor e dor nos tempos da ditadura militar brasileira. São Paulo: Casa Amarela, 2002. 424p.

MARCONI, Paolo. Anistia: começa quinta a reunião nacional. Jornal da República, p. 5, 13 nov. 1979a.

$1979 \mathrm{~b}$.

Anistia: PCB e PCdoB brigam. Jornal da Republica, São Paulo, p. 3, 14 nov. 
MAUÉS, Flamarion; ABRAMO, Zilah Wendel. (Org.) Pela democracia contra o arbitrio: a oposição democrática, do golpe de 1964 à campanha das Diretas Já. São Paulo: Fundação Perseu Abramo, 2006. 480p.

MORAES, Marco Antônio. Congresso pela Anistia deverá rejeitar indulto. Folha de São Paulo, p. 5, 17 nov. 1979.

OLIVEIRA, Elvira de. Levanta, "sacode a poeira e dá a volta por cima”. Em Tempo, São Paulo, p. 5, 22 a 28 nov. 1979.

REGO, OSB. D. Mariano Costa. Catolicismo: a missa pelos mortos da repressão. Jornal da Bahia, p. 6, 11 nov. 1979.

RIBEIRO, Darcy. Aos trancos e barrancos: como o Brasil deu no que deu. Rio de Janeiro: Guanabara, 1985. 5432 tópicos.

SKIDMORE, Thomas. Brasil: de Castelo a Tancredo 1964-1985. Tradução Mario Salviano. Rio de Janeiro: Paz e Terra, 1985. p. 422-427.

SOARES, Gláucio Ary Dillon; D’ARAUJO, Maria Celina; CASTRO, Celso. A volta aos quartéis: a memória militar sobre a abertura. Rio de Janeiro: Relume Dumará, 1995. $328 \mathrm{p}$.

TAVARES, Eduardo Diogo. O milagre de Dom Amoroso. Salvador: P\&A, 1995. 268p.

VIANA, Gilney; CIPRIANO, Perly. Fome de liberdade. Vitória, ES: Universidade Federal do Espírito Santo: Fundação Ceciliano Abel de Almeida, 1992. 276p. 


\section{Colofāo}

\begin{tabular}{|c|c|}
\hline Formato & $17 \times 24 \mathrm{~cm}$ \\
\hline Tipologia & AGaramond \\
\hline Papel & $\begin{array}{l}75 \mathrm{~g} / \mathrm{m}^{2} \text { (miolo) } \\
\text { Cartão Supremo } 250 \mathrm{~g} / \mathrm{m}^{2} \text { (capa) }\end{array}$ \\
\hline Impressão & Setor de Reprografia da EDUFBA \\
\hline Capa e Acabamento & Gráfica Cian \\
\hline Tiragem & 500 exemplares \\
\hline
\end{tabular}

